Szegedi Tudományegyetem

Természettudományi és Informatikai Kar

Földtudományok Doktori Iskola

Gazdaság- és Társadalomföldrajz Tanszék

\title{
A TÖBBSÉGI OKTATÁSI NYELV VÁLASZTÁSÁNAK TÁRSADALOMFÖLDRAJZI KÉRDÉSEI A VAJDASÁGI MAGYAR SZÓRVÁNYBAN
}

Doktori (Ph.D.) értekezés

Trombitás Tímea

Témavezetō:

Dr. Bajmócy Péter

egyetemi docens

Szeged

2020 


\section{Tartalomjegyzék:}

BEVEZETÉS

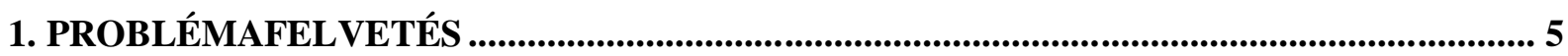

2. ELMÉLETI KERETEK ÉS FOGALMI HÁTTÉR................................................................. 7

2.1. Kisebbségek oktatásának értelmezési lehetőségei ........................................................ 7

2.1.1. Kisebbségi oktatás elméleti megközelítései................................................................ 8

2.2. Kétnyelvűség, nyelvcsere, tannyelvválasztás..........................................................10

2.3. A dolgozatban szereplő fontosabb fogalmak ............................................................

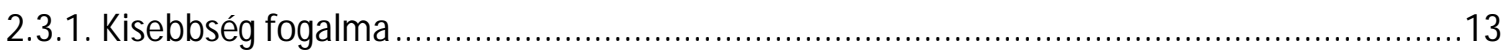

2.3.2. A szórvány meghatározásának dilemmái.............................................................. 14

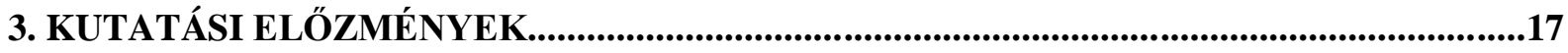

3.1. Kutatások a Kárpát-medence régióiban ............................................................................ 18

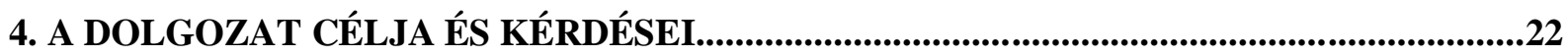

5. AZ ADATGYÜJTÉS ÉS AZ ELEMZÉS SORÁN ALKALMAZOTT MÓDSZEREK.............24

5.1. Az empirikus kutatás sajátosságai és nehézségei .............................................................29

6. VAJDASÁG AUTONÓM TARTOMÁNY BEMUTATÁSA.................................................30

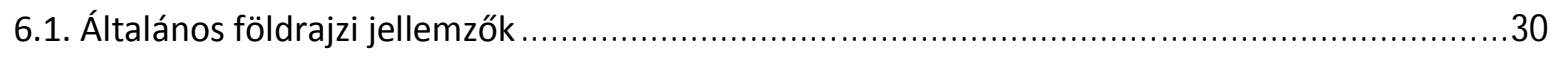

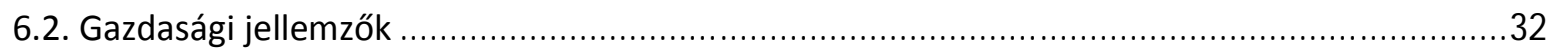

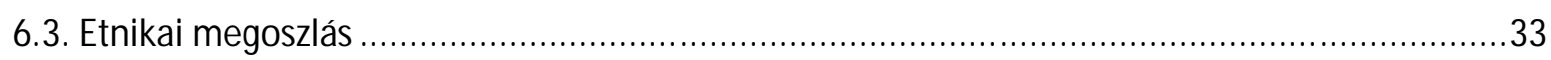

6.3.1. A vajdasági magyarság demográfiai-és társadalomszerkezeti jellemzői ...........................35

7. A VIZSGÁLT TERÜLETEK BEMUTATÁSA (NAGYKIKINDA, ÚJVIDÉK, ZOMBOR)...39

8. KISEBBSÉGI OKTATÁS JELLEMZÖI VAJDASÁGBAN, KÜLÖNÖS TEKINTETTEL A

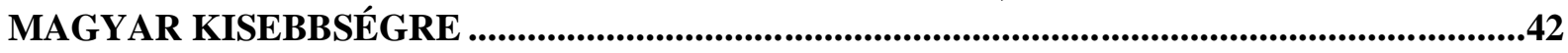

8.1. Tannyelvválasztási stratégiák tömbben és szórványban ..................................................45

9. AZ EMPIRIKUS KUTATÁS EREDMÉNYEINEK ELEMZÉSE .......................................47

9.1. A kutatás tapasztalatai Nagykikindán, Újvidéken és Zomborban ......................................47

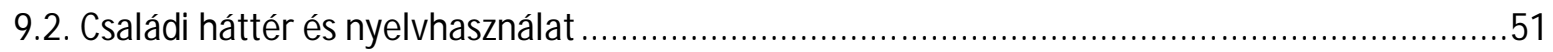

9.2.1. Vegyes házasságból született gyermekek nyelvhasználata ...........................................54 
9.3. Magyar tagozaton tanulók létszámának csökkenése ..........................................................55

9.4. Az iskola- és tannyelvaálasztást befolyásoló szempontok ....................................................59

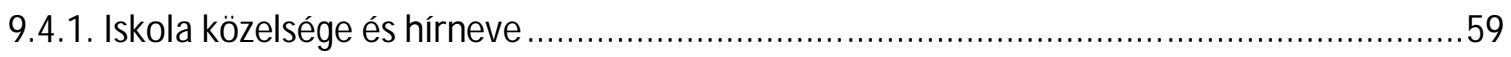

9.4.2. Családi nyelvhasználathoz igazodó iskolaválasztás .........................................................60

9.4.3. Későbbi érvényesülés/boldogulás esélye ........................................................... 61

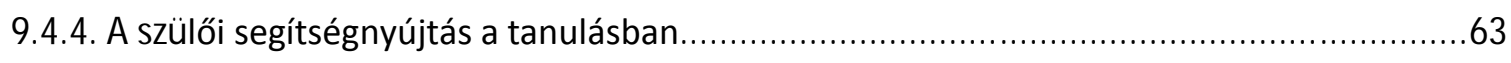

9.4.5. A szülők saját negatív/pozitív tapasztalata ..............................................................64

9.5. Az óvodai/bölcsődei nevelés befolyásoló hatása...........................................................66

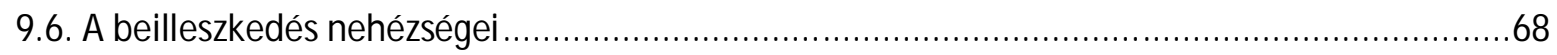

9.7. Pedagógusok véleménye a tannyelvválasztásról .........................................................68

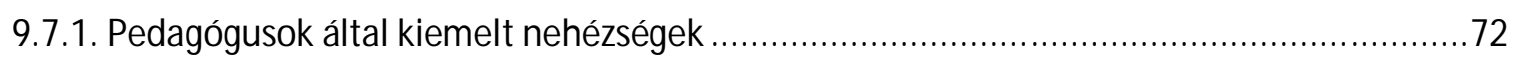

9.8. Az iskola jellemzése és az iskolában folyó oktatás ........................................................... 74

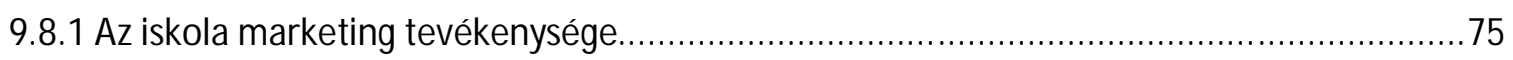

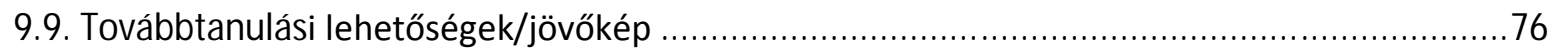

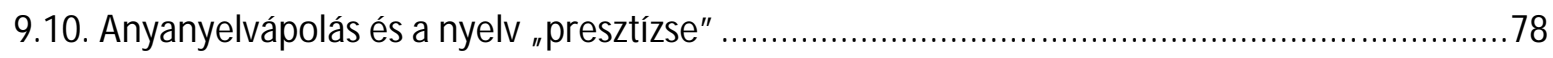

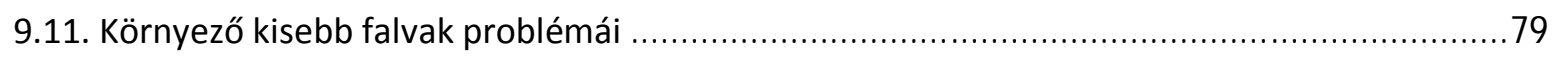

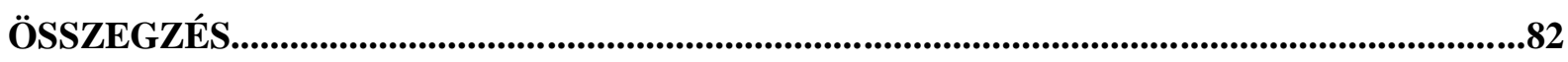

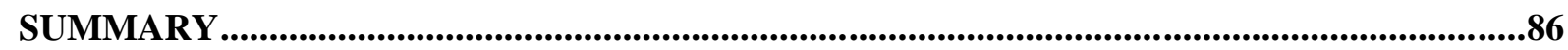

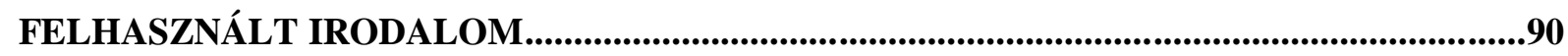

FELHASZNÁLT FORRÁSOK ÉS STATISZTIKAI ADATBÁZISOK......................................101

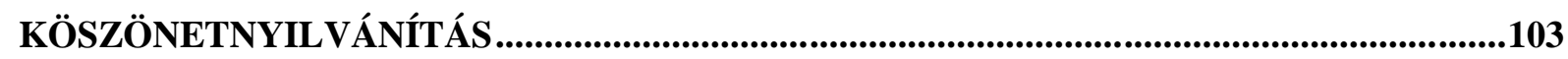

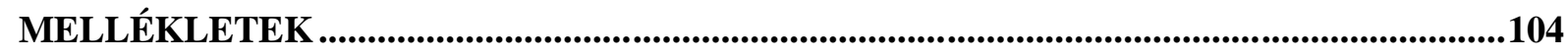

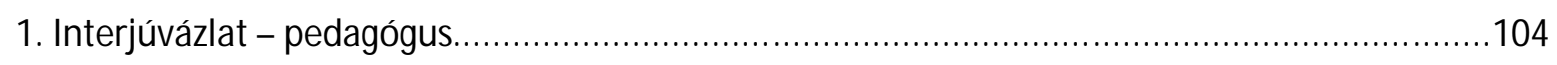

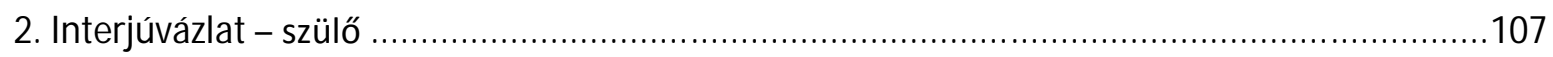

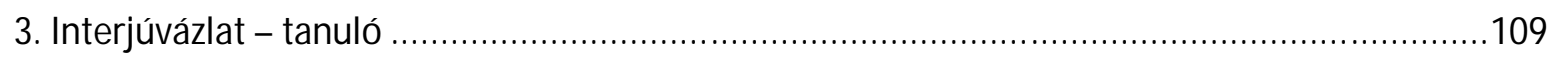




\section{Bevezetés}

Térbeli elhelyezkedésük következtében, a szórványban élő magyar kisebbségek helyzete különleges, hiszen a különböző etnikai, vallási, nyelvi és kulturális sokszínüségük által meghatározott egyének együttélése, és egymásra gyakorolt hatása következtében sajátos társadalmi-kulturális értékek alakulnak ki egy közösségen belül. A heterogén kulturális környezet számos, az identitással, az oktatással, a nyelvhasználattal és az asszimilációval összefüggő kérdést vet fel.

A vajdasági szórványban élő magyar kisebbség anyanyelvhasználata a mindennapok során háttérbe szorul, és olykor használati értéke elsorvad. Ennek következtében felerősödnek az asszimilációs folyamatok, ezért is fontos kiemelten kezelni a szórványterületek magyar nyelvü oktatását. Fontos, tehát az anyanyelvi müveltség, de hasonlóképpen lényeges az államnyelv megfelelő szintü elsajátítása is, hiszen az etnikai környezet sajátosságai megkövetelik az egyéntöl a környezet nyelvének ismeretét (TAKÁCS Z. 2008). E két fontos tényezőt szem előtt tartva igyekekeznek a kisebbségben élő szülök és gyermekeik oktatási nyelvet választani.

Az anyanyelv, és annak megtartása a magyar kisebbség számára, föleg a szórványterületeken élöknek a közösség fennmaradását is jelenti. Ebben komoly szerepet játszik az oktatás nyelve, hiszen a nyelvnek közösségteremtö-, és megörző szerepe van. Mindemellett az anyanyelvü oktatást végző iskola nem csupán ismeretátadást végez, hanem művelődési és nyelvhasználati teret ad a közösség tagjai számára. Azonban, az anyanyelven való tanulás, nem minden esetben magától értetődő dolog, még akkor sem, ha a törvények lehetővé teszik a kisebbségek nyelvén történő iskoláztatást, mivel az iskola kiválasztásakor egyéb szempontok is közrejátszanak, mint például egy család többes kulturális/nyelvi kötődése, vagy a gyermek nyelvtudása (MOLNÁR CsIKÓs L. 1989).

Egy kisebbségi nyelvi, kulturális közegből származó gyermek iskola- és tannyelvválasztása összetett feladat, ugyanis amikor a szülő iskolát, és ezzel együtt tannyelvet (tanítási nyelvet) választ gyermekének, több döntési dilemmával is szembe kell néznie. Az egyik ilyen alapvető dilemma, hogy a gyermek milyen nyelvü iskolai oktatásban részesüljön, hiszen a tannyelv befolyásolja a gyermek későbbi iskolai életútját. Erről a kérdésről megoszlanak a vélemények, ugyanis az oktatás nyelve, és az iskola által képviselt tanterv számos vitára adhat okot, mind a laikusok, mind a szakemberek számára. A családok esetében a tannyelvvel kapcsolatos választás egy döntési sorozat része, amelyben az egyéni elhatározások egymásra épülnek.

A multikulturális, és többnyelvü közösségek iskoláiban gyakori jelenség, hogy a tanuló nem anyanyelvén tanul, illetve iskoláztatása folyamán nyelvet cserél. Ehhez kapcsolódóan, dolgozatom a vajdasági szórványterületeken élő szülők, diákok és pedagógusok véleményét vizsgálja az oktatási nyelv megválasztásának hátteréről, és értelmezi mindezt társadalomföldrajzi szempontból, amely során hangsúlyos szerepet kap a szórványban élő magyar kisebbség társadalma, és a térbeliség tényezője is.

Sok esetben nehéz megnyitni, és fenntartani egy kisebbségi tannyelvü osztályt, ezért a vajdasági szórványterületekre jellemző, hogy az ott élő kisebbség komoly erőfeszítést tesz azért, hogy egy osztályt, ha alacsony létszámmal is, de megnyissanak, ugyanakkor ugyanazon a településen több magyar felmenőkkel rendelkező szülő már a többségi (szerb) nyelven iskoláztatja gyermekét. A nem anyanyelvü képzés melletti döntés egyéni szinten fogalmazódik meg, ám hatása a kisebbségi közösségre is hatással van. Ezért is érdemes megvizsgálni azokat az egyéni döntéseket, mikro-társadalmi jellemzőket, és térbeli 
vonatkozásokat melynek következtében a szórványközösségben élő szülők és gyermekek, akik számára elérhető volt a kisebbségi tannyelven történő oktatás, mégis a többségi nyelven folyó taníttatás mellett döntöttek. A szülök és a diákok megkérdezése mellett, meghatározó a pedagógusok véleményének meghallgatása is, hiszen mindennapi munkájuk és az oktatásban való tapasztalataik alapján igen nagy rálátásuk van a diákok kompetenciájára és a későbbi érvényesülési lehetőségeikre is, ezért dolgozatomban a pedagógusok meglátásai központi helyet foglalnak el.

\section{Problémafelvetés}

Minden tudományágban meghatározó szerepe van a folyamatok és a jelenségek elemzésének, felmérésének. Fontos a szórványközösségek mindennapi élö kultúrájának, társadalmi- és oktatási folyamatainak a nyomon követése, hiszen a valós folyamatok ismeretének függvényében lehet olyan intézkedéseket tervezni, amelyek hozzájárulnak a szórványközösségek valódi problémáinak feltárásához, és értékeinek megőrzéséhez, mivel egy kisebbségi csoport jóléte és állapota össztársadalmi érdeket szolgál.

Kisebbségben, az anyanyelv ápolásának és a kisebbségi identitás megőrzésének egyik legmeghatározóbb eszköze az oktatás, viszont az oktatási nyelv megválasztásában számos egyéb tényező is szerepet játszhat (SCHNEIDER, M. - BUCKLEY, J. 2002; PAPP Z. A. 2012a; MALMBERG, B. et al. 2013; M. CSÁSZÁR Zs. 2011). Mindemellett, a tannyelvválasztással kapcsolatos dilemmát tovább bonyolíthatja, hogy egy kisebbségi csoport egy összefüggő etnikai tömb-, vagy szórvány területen él. Ehhez kapcsolódóan az iskolaválasztás motivációit különböző megközelítésekből vizsgálhatjuk (PAPP Z. A. 2012a). Pragmatikus szempontokat figyelembe véve megkülönböztethetjük a szimbolikus (nyelv és kultúra), és a racionális motivációkat (iskola adottságai), továbbá, ha a kisebbségi közösség területi elhelyezkedését vesszük figyelembe, megkülönböztethetjük a tömbben, és a szórványterületen élők sajátos motivációt, ezen kívül különbséget tehetünk azon személyek (szülő, diák, pedagógus) motivációi között, akik szerepet játszanak a tannyelvválasztás döntésének kialakításában (PAPP Z. A. 2012a).

Az iskolaválasztás során a szülöknek, a diákoknak, valamint a pedagógusoknak is, (akik esetenként a szülőket is megfelelő tanáccsal kell, hogy ellássák) több dolgot kell mérlegelniük, hiszen egy ilyen fontos döntés a gyermek egész további életútját, lelki fejlödését, közösségi és családi kapcsolatait is nagymértékben befolyásolhatja (CSERNICSKÓ I. - GöNCZ L. 2009). Hiszen az oktatás egyik legfontosabb funkciója a kultúra újratermelése, azaz a társadalom által felhalmozott tudás, megalkotott értékek és normák továbbadása az ifjabb generációknak (BOURDIEU, P. 1996; HALÁsZ G. 2001).

Egy területen a kisebbségben élő családok esetében a tannyelv megválasztása sajátos módon bukkan fel a gyermekkor és a nevelés kérdéseivel kapcsolatban. Jelen fejezetben, a problémafelvetéshez kapcsolódóan három olyan tényezőt emelek ki, amely jól érzékelteti, hogy az oktatási nyelv megválasztása valós nehézség elé állítja a szülőket, a diákokat és a pedagógusokat. E három tényező a következő: a társadalmi mobilitás és az oktatási nyelv összefüggési, a választott tannyelv identitásformálásának hatása, illetve a családok etnikai háttere (pl. vegyes nemzetiségü házastársak).

A kisebbségben élő, iskolaválasztás előtt álló szülők számára fontos kérdés, hogy gyermekeik hogyan tudnak a jövőben hatékonyabban érvényesülni, ha anyanyelvükön vagy, ha az adott állam nyelvén (államnyelven) kezdik meg tanulmányaikat. Egy kisebbség szempontjából az iskolaválasztásról hozott döntés, nem csak az iskoláztatás nyelvét határozza meg, hanem a döntés nyelvválasztást és identitásváltást is eredményezhet, hiszen a többségi 
nyelvü iskola a többségi értékeket és szocializációs mintákat közvetíti (LANSTYÁK I. 1994; PRIESTLY, T. 1994; SZÜGYI É. 2014; GÖNCZ L. 2014).

Kisebbségi szempontból vizsgálva, a társadalmi mobilitás szoros összefüggésben áll az államnyelv megfelelő ismeretével, hiszen, ha egy kisebbségi környezetből származó egyén, anyanyelvü képzése mellett nem sajátítja el az államnyelvet, akkor ez számára a munkaerőpiacon csökkenti a sikeres pozíciók megszerzését (PAPP Z. A. 2012b). Ebből a szempontból nézve, az államnyelvnek, mint az érvényesülés nyelvének a szerepe meghatározó, ezért több kisebbségben élö szülő az államnyelven történő iskoláztatást tartja a sikeres társadalmi, és munkaerö-piaci érvényesülés zálogának, tehát az államnyelv (a hatalom nyelvének) választásában benne van a társadalmi elismerésre való törekvés (FODOR D. 2005a). Érdemes, tehát megvizsgálni az iskoláztatás szempontjából a társadalmi státus és az oktatási nyelv összefüggéseit. Andor Mihály és Liskó Ilona véleménye alapján az iskolaválasztás során (legyen szó akármelyik társadalmi csoportról) az a törekvés érvényesül, miszerint a szülők legalább olyan, vagy jobb társadalmi helyzetbe szeretnék hozni gyermekeiket, mint amilyenben ők vannak (ANDOR M.- LISKó I. 2000). Emiatt is számít nehézségnek az oktatási nyelv megválasztására irányuló kérdésfelvetés, hiszen több szülö úgy gondolja, hogy gyermekének a későbbiekben nagyobb lehetőségei lesznek, ha államnyelven kezdi meg tanulmányait, viszont eközben vállalva azt, hogy saját anyanyelve, és kultúrája gyakran háttérbe szorul, ami az egyént az asszimiláció irányába sodorhatja. Cholnoky megfogalmazása szerint a többségi és a kisebbségi nyelv és kultúra versenyében az az érték „győz”, amelyik a diák számára önmegvalósítást és érvényesülést biztosít (CHOLNOKY GY. 2000).

A választott iskola, annak tannyelve és az oktatott tartalmak a tanuló identitásformálásának meghatározó tényezői (GöNCZ L. 2006; GöNCZ L. 1995). Az iskolaválasztás hatást gyakorol a gyermek identitásának későbbi alakulására, hiszen egy adott tanítási nyelven müködő osztály etnikai, identitás-megjelölő szereppel is bír, mivel az egyik, vagy a másik nyelv iránti elkötelezettség meghatározza a nemzeti hovatartozást (FODOR D. 2005a; ÁRENDÁs Zs. 2012). Mindent összevetve megállapítható, hogy a nyelv nem csupán a közvetítés eszköze, hanem a személyiség, illetve a személyes identitás fontos része is (LÁNCOS P. L. 2012).

Papp Z. Attila szerint egy gyermek beiskolázásakor a szülő tudatos vagy a környezet hatására determinált döntése áll, és e döntésének társadalmi, közhasznúsági és gazdasági relevanciája is van (PAPP Z. A. 2013). Az iskolaválasztással kapcsolatos döntés, kisebbségi perspektívából nézve, további egyéni és sajátos szempontokkal is kibővülhet, hiszen az iskoláztatás nyelve nyelvváltást is eredményezhet (PAPP Z. A. 2013). Emiatt egy idő után az anyanyelv elveszíti elsőbbségét a többségi (államnyelv) javára, és a gyermekek számára a szülők nyelve idegenné válik (MIRNICS K. 2003; PÉNTEK J. 2000). Bodó szerint az iskolaválasztás során a szülők nemzeti identitáshoz való viszonya jut kifejezésre, hiszen a szülők a tannyelvválasztással megerősíthetik identitásukat vagy ellenkezőleg: nyitnak (sodródnak) az asszimiláció irányába, mivel az iskoláztatás tannyelve döntő tényező a kétnyelvüség, esetleges nyelvcsere létrejöttében (BODÓ B. 2013). A legtöbb esetben, viszont ennél sokkal inkább gyakorlatiasabb indokok húzódnak meg a háttérben, mint például az iskola közelsége, vagy a tovább tanulás lehetősége.

Ezenfelül fontos szerepet játszik a család etnikai beágyazottsága is, mint amilyen a vegyes házasság, vagy az etnikailag vegyes baráti társaság/rokonság jelenléte is, és ezek a tényezők szórványban nagyobb jelentőséggel bírnak. Bernstein meglátása szerint is egy gyermek nyelvi fejlődésére nagy hatással van környezete, az a társadalmi közeg, amelyben felnövekszik (BERNSTEIN, B. 2002). Szórványterületen jellemző a kétnyelvű vegyes 
házasságok száma, és ezekben az esetekben nehezebb eldönteni, hogy a gyermek mely szülő nyelvét tekinti majd a sajátjának (MIRNICS K. 1994). De Klerk (2001) tanulmányában leírtak szerint, a vegyes nemzetiségü házastársak esetében, a családi nyelvpolitika sikere vagy kudarca többnyire a szülői elkötelezettségnek, és a kulturális háttér fenntartásának a függvénye, amelyet több külső tényező is befolyásolhat, úgy, mint a történelmi, társadalmi és politikai tényezők (DE KLERK, V. 2001). Mindemellett a család, mint mikroközösség, sajátos dinamikai erőtér, amelyben egyedi viszonyok alakulnak ki (VAJDA ZS. - KósA É. 2005).

Szülöi szemszögből nézve, a tannyelvválasztás (nyelvválasztás) összefüggésbe hozható a nyelvek presztízsével, vagyis azokkal a „vélt vagy valós elképzelésekkel”, amely szerint valamelyik nyelv sikeresebb életpályát biztosíthat a gyermek részére (PAPP Z. 2012a). A kettős vagy többes etnikai, nyelvi, kulturális kötődésekkel rendelkező szülök esetében tehát különleges helyzet áll elő, akik ráadásul gyakran eltérő iskolázási mintákat képviselhetnek, például az egyikük kisebbségi nyelven tanult, a másikuk államnyelven végezte iskoláit (ÁRENDÁs Zs. 2012). Ezekben az esetekben a döntés nehezebb, hiszen nincs jelen az iskolába íratásnak az a fajta természetes automatizmusa, amely a homogén nemzetiségü családoknál döntő mértékben előfordul (ÁRENDÁs Zs. 2012). Bartha munkájában saját, és más korábbi kutatásokra hivatkozva megállapítja, hogy a vegyes házasságok esetében az iskolaválasztás többnyire a többségi nyelvü iskolai oktatást eredményezi (BARTHA Zs. 2014). Dobos és Sorbán szintén arra a meghatározásra jutottak, hogy a vegyes házasságokból (ahol az egyik fél magyar nemzetiségü) született gyermekek általában államnyelvü képzésben vesznek részt (DobOs F. 2011; SORBÁN A. - DobOS F. 1997).

\section{Elméleti keretek és fogalmi háttér}

E fejezet a könnyebb áttekinthetőség érdekében három nagyobb alfejezetre tagolódik. Az első részben a kisebbségek oktatásának értelmezési lehetőségeit, és a kisebbségi oktatás elméleti megközelítését elemzem. A második alfejezetben a kétnyelvüség, a nyelvcsere és ehhez kapcsolódóan a tannyelv-választás fogalomkörével és folyamatával foglalkozom röviden, illetve néhány nemzetközi példa segítségével ismertetem a kisebbségek oktatásának lehetséges rendszerét. Az utolsó fejezetben, a téma szempontjából a két legfontosabb kifejezést: a kisebbség, és a szórvány fogalmának meghatározását tekintem át.

\subsection{Kisebbségek oktatásának értelmezési lehetőségei}

A dolgozatomban az elméleti háttér kidolgozása során Papp Z. Attilának az iskolaválasztás megközelítésének elméleti modelljeiről szóló tanulmánya jelentette a kiinduló pontot (PAPP Z. A. 2012a; PAPP Z. A. 2012b; PAPP Z. A. 2013; PAPP Z. A. 2014a). Nevéhez füződnek a határon túli magyarok tannyelvválasztási szokásairól és eredményességeihez füződő legáltalánosabb megállapítások. Munkáiban, mind a piaci mechanizmusok, mind a kisebbségi kontextus függvényében elemzi az iskolaválasztással kapcsolatos motivációs tényezőket (HíRES-LÁSZLó K. 2016). Tanulmányaiban több külföldi szerző munkájára hivatkozva (HeCKMAnN, F. 2008; McDonough, P. M. - FAnN, A. J. 2007; Condron, D.J. 2009; EUMC 2006) a kisebbségi oktatás sajátosságaira adható magyarázatokat makro-, mezo, és mikroszinten csoportosította. Makroszint alatt azokat az iskolaválasztáshoz kapcsolódó motivációkat kell érteni, amelyek az oktatási rendszer egészével kapcsolatosak, mezoszint az iskolához szorosan kapcsolódó tényezőkent jelenti, míg a mikroszint az egyéni döntések motivációit jelenti (1. ábra). A szintek között létezik átjárhatóság, hiszen a makrotényezők (oktatási rendszerhez kapcsolódó tényezők) kihatással vannak az iskola vagy az egyén/család szintjére, illetve ,ami egyéni vagy intézményi szinten érvényesül, annak vélhetően 
rendszerszintü okai is vannak". Továbbá megkülönbözteti az etnicitással közvetlenül összefüggő, és az etnicitással közvetlenül nem összefüggő tényezők csoportját is, és kiemeli, hogy ezen tényezők a gyakorlat során gyakran összemosódhatnak, hiszen az etnikailag látszólag semleges tényezők könnyen etnikai színezetet kaphatnak, és fordítva (PAPP Z. A. 2013). Jelen dolgozat e felvázolt rendszeren belül a mikroszinthez kapcsolódik, vagyis az egyéni döntések hátterében meghúzódó motivációkat kutatja.

1. ábra: A kisebbségi oktatás sajátosságait magyarázó tényezők

\begin{tabular}{|c|c|c|}
\hline Makroszintū magyarázatok & Mezoszintű magyarázatok & Mikroszintü magyarázatok \\
\hline \multicolumn{3}{|l|}{ Etnicitással összefüggő } \\
\hline $\begin{array}{l}\text { 1) Nemzetállami keret és etnopolitikai } \\
\text { kömyezet; } \\
\text { 2) Deszegregációs politika; } \\
\text { 3) Lingvicizmus; } \\
\text { 4) Etnokulturalista magyarázatok } \\
\text { 5) Diszkrimináció; } \\
\text { 6) Társadalmi elóítéletek és interetnikus } \\
\text { kapcsolatok rendszere; } \\
\text { 7) Kisebbségek kurikuláris jelenléte; }\end{array}$ & $\begin{array}{l}\text { 1) Iskolák közötti és iskolán belüli szeg- } \\
\text { regáció; } \\
\text { 2) Anyanyelvi programok, önkéntes szeg- } \\
\text { regáció; } \\
\text { 3) Tanár-diák kapcsolat, pedagógusok } \\
\text { elvárásai; } \\
\text { 4) Kisebbségi tanulási útvonalak; } \\
\text { 5) Oktatást támogató civil társada- } \\
\text { lom léte; } \\
\text { 6) Család iskolával szembeni elvárásai; }\end{array}$ & $\begin{array}{l}\text { 1) Család kulturális tôkéje; } \\
\text { 2) Etnikai stereotípiák; } \\
\text { 3) Államnyelvi kompetenciák megléte; } \\
\text { 4) Ifjúsági kultúra sajátosságai; }\end{array}$ \\
\hline \multicolumn{3}{|l|}{ Etnikailag semleges } \\
\hline $\begin{array}{l}\text { 1) Az ország külső-belső regionális kör- } \\
\text { nyezete; } \\
\text { 2) Oktatási rendszer filozófiája; } \\
\text { 3) Rendszer müködése (korai szelek- } \\
\text { ció, óvodátatás, centralizáció-decent- } \\
\text { ralizáció); } \\
\text { 4) Pedagógiai képzés, továbbbépzés } \\
\text { rendszere; }\end{array}$ & $\begin{array}{l}\text { 1) Iskola mint szervezet; } \\
\text { 2) Iskolai erőforrások megléte; } \\
\text { 3) Pedagógusok társadalmi összetétele; } \\
\text { 4) Pedagógusok bérezése (alulfizetés, } \\
\text { korai kiégés); } \\
\text { 5) Használható pedagógiai kultúra; } \\
\text { 6) Iskolaszerkezet, iskola-előkészitő ok- } \\
\text { tatás léte; } \\
\text { 7) Település szintü szegregáció; }\end{array}$ & $\begin{array}{l}\text { 1) Család szociális és gazdasági iőkéje/ } \\
\text { pozíciója (egészségi állapot, családszer- } \\
\text { kezet, lakáskörülmények, munkanélkülli- } \\
\text { ség, jövedelem mértéke); } \\
\text { 2) Belső migráció, lakóhely váltotatatás; } \\
\text { 3) A célországban eltöltött idő és mo- } \\
\text { tivációja }\end{array}$ \\
\hline
\end{tabular}

Forrás: PAPP Z. A. (2012b), 9.o.

Papp Z. Attila (2014a) munkájában megkülönbözteti a kisebbségeket érintő oktatási formák főbb típusait is. Véleménye szerint anyanyelvi oktatásról akkor beszélünk, ha a kisebbségek tagjai saját anyanyelvükön tanulnak, és ha ez az anyanyelvi oktatás kiterjed a rendszer egész vertikumára, ebben az esetben a kisebbségek anyanyelvén történő képzése a nemzetállami keretekben müködő oktatási rendszer alrendszerének tekinthető. Mindazonáltal, a kisebbségek oktatása horizontálisan akár részleges is lehet. Ez egyrészt a kétnyelvü oktatás által valósulhat meg, vagy abban az esetben, ha az oktatás során csak bizonyos anyanyelvi modulokra van lehetőség. Egy országon belül a legtöbb esetben a kisebbségi oktatás részrendszer, azaz a fő erőforrásait, jogi keretét a többségi állam szereplői és eljárásai biztosítják. A nemzeti kisebbségek anyanyelvi oktatásának ellenpólusa az oktatási szolgáltatások államnyelven való igénybevétele (PAPP Z. A. 2014a).

\subsubsection{Kisebbségi oktatás elméleti megközelítései}

A kisebbségi oktatás elméleti megközelítését a kutatás szempontjából fontos, négy elmélet ismertetésével, rövid elemzésével vezetem fel. Jelen fejezetben a következő kisebbségi oktatást befolyásoló makroszintü tényezőkkel foglalkozom: lingvicista megközelítés, az etnokulturalista magyarázatok, a társadalmi elöítéleteket és az interetnikus 
kapcsolatok rendszere, illetve a kisebbségek kurrikuláris és iskolai jelenlétének megközelítése.

A kisebbségi oktatás lingvicista megközelítése Skutnabb-Kangas svéd nyelvészhez kötődnek (SKUTNABB-Kangas, T. 1994; SkUtnabB-Kangas, T. 1997). A lingvicizmus szakkifejezést általában a különböző nyelveket beszélő csoportok közötti társadalmi diszkriminációra használják (KONTRA M. 2005). E szemlélet valójában a kisebbségi csoport sajátos céljait, illetve az állam kisebbségekkel kapcsolatos stratégiáit, és oktatáspolitikai elképzeléseit fogalmazza meg. Skutnabb-Kangas a kisebbségi oktatásra vonatkozó magyarázatokat két nagyobb csoportra osztja fel: a hiányelméletekre, és a gyarapodáselméletekre. A kisebbségi oktatásra vonatkozó hiányelméletek azon az elképzelésen alapulnak, miszerint a kisebbségi közösségekböl származó diákoknak kell alkalmazkodnia a többségi nyelven müködő iskolához, és az alkalmazkodás folyamata során az „örökölt” nyelvi, kulturális és társadalmi hátrányokat le kell küzdeni, mindaddig, amíg a gyermek többségi nyelvüvé nem válik. A hiányelméletek az integráció folyamatát a kisebbségek számára szóló teendőnek tekinti, tehát a kisebbségi csoportnak kell alkalmazkodnia a többségi társadalomhoz (PAPP Z. A. 2014a). Az lingvicista megközelítés másik csoportja, a gyarapodáselméletek szerint az iskolának kell alkalmazkodnia a tanuló sajátos igényeihez. Ezen elképzelés szerint a kisebbségi gyermek anyanyelvét, és kulturális hátterét pozitívumként kell értékelni, továbbá a kétnyelvüséget és a két kultúrába való illeszkedést, a társadalmat gazdagító, és a gyermeket ösztönző jelenségnek kell tekinteni (SKUTNABB-KANGAS, T. 1994). Ezen elméletet kisebbségközpontúnak tekinthetjük. A lingvicizmusra a közép- és kelet-európai térségben, illetve a nyugat-európai államokban is találhatunk példát. A hiányelméletek szemlélete alapján ide sorolhatjuk a Nyugat-Európába bevándorolt csoportok egy részét, akik arra törekszenek, hogy integrációjuk sikeres legyen a helyi társadalomba, ezáltal a kisebbségi csoport tagjai igyekeznek minél gyorsabban elsajátítani az adott ország nyelvét. A gyarapodáselméletek sorába pedig a Magyarországon müködő kisebbségi oktatás bizonyos szegmenseit sorolhatjuk, illetve ezen elméletek körébe tartozik a határon túli magyar kisebbségi oktatás is, hiszen ezen esetekben az állam elismeri a kisebbségek létét és nyelvét. A jugoszláv utódállamokban ma is létező kétnyelvü oktatás, vagy a többségiek számára oktatott kisebbségiek által használt ún. környezetnyelv a Skutnabb-Kangas által említett kétnyelvüség értékeit tűzik ki célul (PAPP Z. A. 2014a).

Az etnokulturalista magyarázatok abból a szemléletből indulnak ki, hogy a kisebbségi csoportok között alá/fölérendeltségi viszonyok alakultak ki. Az etnikai jellegü iskolázottsági esélyegyenlötlenségek vizsgálatában John Ogbu (OGBU, J. 1978; OgBU, J. 1981; OGBU, J. 1993; OGBU, J. 1997) elmélete máig az egyik legnagyobb vitákat kiváltó elméletek közé tartozik (PÁSZTOR A. 2006). Ogbu, elsősorban az USA-ra vonatkoztatható, a kisebbségi csoportok oktatását elemezve egy kulturális-ökológiai modellt állított fel. Elméletében a kisebbségeket három csoportba sorolja: az autonóm, a bevándorló (vagy önkéntes), illetve nem önkéntes (vagy kasztszerü) kisebbségek (PAPP Z. A. 2014a). Az autonóm kisebbségek lélekszámukat tekintve is számottevőek, valamint sajátos etnikai, nyelvi, vagy vallási jellegzetességekkel bírnak. A bevándorló kisebbségek önkéntesen érkeztek az Egyesült Államokba, míg a harmadik kisebbségi csoport képviselői a gyarmatosítás vagy a rabszolgamunka következtében kerültek oda, és alárendelt helyzetükön változtatni szeretnének. Míg az első két csoport tagjai elfogadják a többségi társadalom által képviselt értékeket és eszmerendszert, addig a kasztszerü csoportok kitermelik másodlagos kulturális különbözőségeiket, amely ellenkultúraként is értelmezhető. Ogbu szerint míg az őshonos és bevándorló kisebbségek iskolai teljesítménye átlagos vagy átlag fölötti, addig a nem önkéntes kisebbségi csoportok alulteljesítenek, amelynek oka éppen az általuk felállított, a többségi 
társadalom értékeit elutasító kulturális keret (PAPP Z. A. 2014a; VAJDA Zs. - KósA É. 2005). Elméletét azonban több oldalról is megkérdőjelezik, hiszen megközelítése leegyszerüsítő és általánosító. Az elmélet figyelmen kívül hagyja az egyes kisebbségi csoportok belső rétegzettségét, a kulturális keret dinamikáját (PAPP Z. A. 2014a). Ennek ellenére Ogbu elméletét azért érdemes kiemelni, mert az általa alkotott szabad akaraton, avagy az önkéntességen alapuló tipizálás lehetővé teszi a bevándorlók és a nemzeti kisebbségek megkülönböztetését (PÁSZTOR A. 2006).

A társadalmi elöítéletek és interetnikus kapcsolatok rendszerének megközelítése szerint az előítéletek kihatással lehetnek egy állam etnopolitikai jellegzetességeire, ennek alapján az etnikai csoportokkal szembeni elfogultság (akár negatív, akár pozitív irányú), elősegíthetik vagy hátráltathatják a kisebbségi oktatás sikerességét (PAPP Z. A. 2014a). A elöítéletesség a mindennapi interetnikus együttélés folyamatait is befolyásolhatja, amely így kevesebb lehetőséget ad a többségi és kisebbségi csoportok közötti együttmüködésre, ez pedig gyakran diszkriminációhoz is vezethet. Egy társadalomban minél nagyobb az elöítéletesség mértéke, annál több lehetséges akadály alakulhat ki a kisebbségek sikeres iskoláztatásával szemben, és minél kisebbek az etnikai csoportok közötti társadalmi távolságok, annál nagyobb lehetősége van valamiféle kisebbségbarát oktatáspolitika, illetve a másságot befogadó iskolai kultúra kialakulásának (PAPP Z. A. 2014a).

A kisebbségek kurrikuláris és iskolai jelenlétének megközelítése abból indul ki, hogy a kisebbségek iskolai tananyagban való jelenléte erősítheti a kisebbségi csoportok önértékelését, és ezzel egy időben a többségi társadalom tanulóinak toleráns viszonyulását is. A kurrikuláris jelenlét vagy hiány rejtett üzenetként müködik, és a társadalom kisebbségekkel szembeni ideologikus vagy attitüdbeli stratégiáját, a pozitív vagy negatív sztereotípiák kialakulását szolgálja. Hasonlóképpen modellként szolgálhat a kisebbségiek számára, és ezáltal növelheti az oktatási szolgáltatások iránti igényt az, ha az oktatási rendszerben kiépült csatornái vannak a kisebbségi pedagógusok jelenlétének (képzésének és továbbképzésének). Megjegyzendő azonban, hogy a nyelvi oktatási alrendszerrel rendelkező kisebbségek esetében a pedagógusképzés túlterjedése veszélyeket is rejthet. A többséginél pusztán számbeli korlátok miatt is még szükösebb erőforrásokkal rendelkező csoport számára ugyanis komoly kockázatokat rejt, ha az oktatási expanzió következtében a társadalmi presztízsét részben vesztett szakmára részarányosan többet képez, mint más (magasabb presztízzsel rendelkező) szakmákra (PAPP Z. A. 2014a).

\subsection{Kétnyelvüség, nyelvcsere, tannyelvválasztás}

Tudjuk, hogy a nyelv a kultúra egyik legfontosabb, legtartósabb, de ugyanakkor a legellentmondásosabb alkotórésze is, hiszen összeköti, de egyúttal szét is választja embereket (HAGGETT, P. 2006). Egy társadalmon belül, a többségi, és a kisebbségi közösségek közti különbségek meghatározásának egyik leglényegesebb jellemzője a nyelv (HAGGETT, P. 2006).

Az uniós nyelvpolitikai diskurzusban a többnyelvüség, a nyelvi sokszínüség kiemelten jelenik meg, ahol a nyelvi sokszínüség nem teher, hanem érték (ERDEI I. 2010; GOMBOS G. 2010; SzOTÁK Sz. 2013). Ezzel ellentétben a kisebbségi kétnyelvüségre egyfajta kényszertöbbnyelvüségként tekintenek, és nem kerül elö az érték-többnyelvüség jelensége, inkább a nyelvcsere folyamatokra, a nyelvi asszimiláció kérdésére asszociálnak (ERDEI I. 2010).

Általánosságban elmondható, hogy az egymással kapcsolatba kerülő nyelvek kölcsönösen hatnak egymásra, és ez fokozottabban érvényes a heterogén nemzeti közösségekre, ahol a többségi nyelv jelentősebb mértékben hat a nemzeti kisebbségek nyelvhasználatára, mint fordítva (ANDRIĆ E. 2003). A nyelvet tekinthetjük a legalapvetőbb kulturális jelenségnek, a nyelv a társadalomban való részvétel eszköze is, így a nyelvi 
szocializáció meghatározó része a társadalomba való beilleszkedés folyamatának (ERDEI I. 2011). Multietnikus környezetben, a kisebbségi csoportok tagjai számára a kétnyelvü /többnyelvü lét megszokott jelenség, hiszen mind a nyelvileg vegyes család, mind pedig az egynyelvü, de a környezet nyelvétől eltérő nyelvet beszélő család több nyelvet használ (ERDEI I. 2010).

A kétnyelvűség világszerte ismert jelenség, egyes vélemények szerint az emberiség többségére kiterjed (GEREBEN F. 2007; BARTHA CS. 1999). Vélekedések szerint az anyanyelven kívüli más nyelvek ismerete, bővíti az ember látókörét, empatikusabbá teheti különböző kultúrák és identitások iránt (GöNCZ L. 1985; KISS J. 1995; BARTHA CS. 1999; GEREBEN F. 2007).

A kétnyelvüség Grosjean szerint, két (vagy több) nyelv rendszeres használatát jelenti, és kétnyelvünek azok a személyek tekinthetőek, akiknek a mindennapi életük során két (vagy több) nyelvre van szükségük, és ezeket használják is (GROSJEAN, F. 1982). Andrić megfogalmazása szerint a kétnyelvüség fogalmán két nyelv anyanyelvi szinten történő használatát kell érteni, vagyis az anyanyelv és egy másik nyelv megközelítőleg azonos szintü ismeretét (ANDRIĆ E. 2004). Ezen megfogalmazások mellett a kétnyelvüségre egyéb más definíciók is alkalmazhatóak, ugyanis a kutatók szerint többféle kétnyelvüség létezik, viszont a meghatározások közös pontja, hogy kétnyelvünek azokat a személyeket tekinthetjük, akik hétköznapi kommunikációjuk során két nyelvet használnak.

Andrić (2004) a kétnyelvüség kialakulásának két nagy típusát különbözteti meg, amelyek a vajdasági közösségre is érvényesek. Az első nagy típusba a természetes, spontán úton létrejött kétnyelvüek csoportja tartozik, amely csoport tovább bontható két további altípusra. Az első altípusba azon gyermekek tartoznak, akik vegyes házasságban születtek és egyidejüleg, párhuzamosan sajátítják el mindkét szülö nyelvét. A kutató ezt a fajta kétnyelvüséget kiegyensúlyozott kétnyelvüségnek nevezi, mert a gyermek mindkét nyelven meg tudja formálni gondolatait, és fejében nem fordítja le mondatait egyik nyelvről a másikra. Később, amikor ezek a gyermekek iskoláskorba kerülnek és oktatási nyelvet választanak maguknak, ez az egyensúly felbomlik egyik vagy másik nyelv javára. A másik altípus szerint, a kétnyelvüség kialakulásához az a társadalmi többnyelvü környezet járul hozzá, amelyben a gyermek felnövekszik, ugyanis lakosság nemzetiségi összetétele nagymértékben befolyásolja a kétnyelvűség fokát. Ezen eseteknél a kisebbségi családból származó gyermek a szélesebb társadalmi közösségtől tanulja el a második nyelvet (az államnyelvet). A kétnyelvüség kialakításának másik nagy típusa, a második nyelv intézményes tanulás (oktatás) útján való elsajátítása, amelyet az előzőekkel ellentétben mesterséges kétnyelvüségnek tekinthetünk (ANDRIĆ E. 2004). Az intézményes nyelvoktatás már az óvodában jelen van, de jellemzően csak általános iskolától kezdve fektetnek rá nagyobb hangsúlyt. Ezekben az esetekben az anyanyelv domináns marad, a második tanult nyelvvel szemben (ANDRIĆ E. 2004).

Csernicskó és Göncz (2009) munkájában hozzáadó és felcserélő kétnyelvüségről tesznek említést. A hozzáadó kétnyelvüség során a nemzetiségileg és a nyelvileg vegyes környezetben használt nyelveket, és a hozzájuk „tartozó” kultúrákat nem rangsorolják, hanem egyformán értékelik. Ebben az esetben a használt nyelvek tanulása vonzó cél, és ritka a nyelvcsere, az egyik nyelvhez hozzáfejlődik a másik nyelv (CSERNICSKó I. - GÖNCZ L. 2009). A felcserélö kétnyelvűség esetében pedig, a környezet az egyik nyelvet és kultúrát fontosabbnak tartja a másiknál, az az előnyben részesíti. Legtöbbször a leértékelt nyelvet felcserélik a felértékelt nyelvvel, ez a fajta helyzet a nyelvcseréhez, beolvadáshoz vezet. A szerzők munkájukban kiemelik, hogy a felcserélő kétnyelvüség következményeként előfordulhat mindkét nyelv hiányos ismerete is (CSERNICSKÓ I. - GöNCZ L. 2009). 
A heterogén, sokszínü nemzeti és nyelvi közösségben a kétnyelvűség természetes, és olykor magától értetődő folyamat. Ez számos helyen megszokott jelenség, és elfogadott az a nézet is, hogy a kisgyermekek nagyobb erőfeszítés nélkül tudnak elsajátítani két vagy akár több nyelvet is (PETITTO, L. A. et al. 2001). Ugyanakkor létezik egy ezzel ellentétes vélemény is, miszerint a korai kétnyelvű elsajátítás valamilyen formában negatív hatással lehet a gyermek fejlődésére (MACNAMARA, J. 1967).

Puskás tanulmányában Skutnabb-Kangas megközelítését emeli ki, miszerint a kisebbségben élő egyének számára a kétnyelvüvé válás elmulasztása végezetes következményekkel járhat, és ehhez kapcsolódóan a sikertelenség három tipikus esetét különbözteti meg (PUSKÁs T. 2000, SKUTNAAB-KANGAS, T. 1981). Az első esetben az egyén egynyelvü marad vagy az anyanyelvén domináns, tehát a továbbtanulási esélyei korlátozottak lesznek, a második esetben az egyén által tökéletesen elsajátított második nyelv lesz az egyén domináns nyelve, míg az anyanyelvét elfelejti, esetleg rosszul beszéli. Ebben az esetben nagy az esélye annak, hogy ez az egyén az etnolingvisztikai csoporttól, melyhez korábban tartozott, elidegenedik, gyökértelennek érzi magát, és az etnikai hovatartozás kérdései problematikussá válnak a számára. A harmadik esetben az egyén mindkét nyelvet rosszul beszéli, tehát a korábbi két esetben felvázolt problémák halmozódnak (PUSKÁs T. 2000, SKUTNABB-KANGAS, T. 1981).

Susan Gal (1991) véleménye szerint, általánosságban kijelenthető, hogy a legtöbb esetben az államnyelv kiszorítja a kisebbség nyelvét. Hozzáteszi, hogy a kétnyelvűség sokszor mint átmeneti szakasz szerepel a nyelvcsere folyamatban, de lehet állandó állapot is. A nyelvcsere kialakulásához külső (politikai és gazdasági viszonyok, lakóhely, munkahely, iskola), és belső (mentalitás, nyelvekhez füződő attitűdök, nyelvek presztízse) tényezők is hozzájárulhatnak, illetve befolyásolhatják azt (GAL, S. 1991).

Európa, sőt a világ valamennyi országát etnikai és nyelvi sokféleség jellemzi, ezért a kisebbségben élők oktatásának és tannyelvválasztásának a nehézségei nem sajátosan magyar jelenség, ezért e kérdésben nemzetközi kitekintésre is szükség van. Külföldi példák egész sorát lehetne idézni az iskolaválasztás változatos gyakorlatainak szemléltetésére, kiemelve és egymással összevetve a különbségeket (ÁRENDÁs Zs. 2012). Dolgozatomban ezek közül csak néhányra teszek említést. Québec oktatásügyi berendezkedése gyakran idézett példa a kisebbségi-többségi iskolák kérdéskörének elemzésekor, hiszen francia és angol nyelvü iskolák egyaránt rendelkezésre állnak a kisebbségek által lakott területeken (ÁRENDÁs Zs. 2012). Egy a kanadai szülők iskolaválasztási mintáit vizsgáló tanulmány szerint számos nemetnikus szempont érvényesül az iskolaválasztás során (GUILLEMETTE, Y. 2007). A kutatás ismerteti, hogy a nem-etnikus szempontok közül leginkább az iskola közelsége, és az intézmény jó tanulmányi eredményei képezték a legnagyobb vonzerőt. Mindemellett további fontos tényezőként jelent meg, hogy ha az intézményt korábban már látogatta a család egy gyermeke, vagy ha a baráti körből valaki ajánlotta az iskolát, illetve, ha olyan, speciális oktatási-módszertani mintát követ az iskola, amelyet más környező iskola nem biztosít, és ezzel az intézmény kiemelkedik az átlagból. A kutatás eredményei szerint az oktatás piacosodó jellege miatt a nem-etnikus szempontok közül az iskola által kínált minőségi oktatás kiemelt szempontnak számít.

Létezik egyfajta nyugati-európai liberális modell, ahol az egyenlő bánásmód elve érvényesül, viszont egyesek a kisebbségek megkülönböztetett bánásmódját, és a pozitív diszkrimináció elvét szeretnék szorgalmazni (ÁRENDÁs Zs. 2012). A finnországi svédek, és az olaszországi németek helyzete szintén gyakran idézett példa a kisebbségi oktatás tekintetében (GYÖRI SZABÓ R. 1999; PÁSZTOR A. 2006). Finnországban a svéd kisebbségnek saját, a finnel párhuzamos iskolarendszere van. Az oktatási minisztériumban külön részleg foglalkozik a 
svéd nyelvü iskolaüggyel, valamint az oktatási rendszeren belül a kisebbségre nézve kedvező, pozitív diszkrimináció érvényesül. A svéd nyelvű oktatásban a tanárok svéd anyanyelvűek, és a tanítás nyelve kizárólag a svéd, egyedül a finn nyelv oktatása történhet svéd vagy finn nyelven (GYÖRI SZABÓ R. 1999). A finnországi példával egyetemben a Dél-Tiroli német kisebbség helyzetét „szokás” még megemlíteni, ugyanis a tartományban mindkét nyelven, olaszul és németül is egyaránt lehetőség van tanulni (PÁsZTOR A. 2006).

A négy nagyobb határon túli magyar közösségnek (Romániában, Szerbiában, Ukrajnában és Szlovákiában) szintén lehetősége van az anyanyelvü oktatásra, az óvodai neveléstől a felsőfokú képzésig (részben). Ezekben a régiókban a kisebbségi oktatás főleg a magyar nyelvet többé-kevésbé a családban is domináns nyelvként használó diákokat célozza meg (PAPP Z. A. 2014a).

Magyarországon a kisebbségi oktatás lehet anyanyelvü, kétnyelvü, nyelvoktató és kiegészítő jellegü is (PAPP Z. A. 2014a). A külhoni magyarok oktatásától eltérően, a magyarországi kisebbségi oktatás sok esetben csak a nyelvoktatásról szól, és kevés diák vesz részt az oktatás egészére kiterjedő nemzetiségi nyelvü oktatásban, illetve az oktatási intézményeknek csak kis része nemzetiségi tannyelvű (MARIÁN B. - SZABÓ I. 2003). Ezzel ellentétben a határon túli magyarok esetében az oktatási alrendszer léte lehetővé teszi a magyar - azaz a kisebbségi - nyelv használatát akár a felsőoktatásban is. A magyarországi kisebbségeket érintő oktatás nyelvileg meglehetősen asszimilálódott és méretét tekintve kis etnikai közösségeket érint. Míg a határon túliak esetében visszatérő oktatáspolitikai téma a többségi nyelv elsajátítása, addig a magyarországi nemzetiségek esetében, éppen az iskolarendszer sajátosságaival, illetve csoportnagyságukkal is összefüggő elörehaladottabb asszimilációjuknak köszönhetően a kisebbségi nyelv megőrzése és fenntartása a kulcskérdés (PAPP Z. A. 2014a).

\subsection{A dolgozatban szereplő fontosabb fogalmak}

Munkám során fontosnak tartom néhány fogalom definiálását, hiszen a kisebbség fogalma, de főleg a szórvány fogalmának meghatározása sokrétü, olykor képlékeny és több kutatási nézőpontból is vizsgálható. Jelen fejezetben, főként a kisebbség és a szórvány meghatározását ismertetem, e mellett a nemzet és a diaszpóra fogalmát is elemzem röviden.

\subsubsection{Kisebbség fogalma}

A többség-kisebbség fogalompárossal a mindennapi nyelvhasználat során elsősorban demográfiai arányviszonyokat jelölnek, miszerint egyik csoport nagyobb a másiknál (HoRVÁTH I. 2006). Dolgozatomban előforduló többség és kisebbség kifejezés tartalma szintén a népesség létszámbeli arányára történő utalás. Munkám során a többségi nyelv alatt a szerb nyelvet, az államnyelvet értem, míg a kisebbségi nyelv kifejezés a Szerbiában élő kisebbségek nyelvére, köztük a magyar kisebbség nyelvére való hivatkozás.

A kisebbség fogalmának megértéséhez először tisztázni kell a nemzet fogalmát és kettős értelmezhetőségét, ugyanis az eltérő fogalomértelmezés főként az eltérő történelmi fejlődéssel hozható összefüggésbe (IzSÁK É. 2002). A középkori Európában a nemzet fogalma inkább rendi és regionális kategória volt, az azonos területen élő és azonos jogállású személyek csoportját jelentette, majd később az újkori Európában egyre inkább politikai kategóriává vált (BAJMÓCY P. 2009).

A nemzet fogalma a modern európai történelemben két csoportra különül el, az egyikre a közös területhez, az államhoz való tartozás, míg a másikra a közös nyelv, a kultúra és a közös származás azonossága a jellemző (IzSÁK É. 2002). Az első típust, Meinecke német történész, politikai vagy államnemzetként definiálta, míg a második típust kultúrnemzetként 
határozta meg (IzSÁK É. 2002). Az államnemzet jelentése egy ország valamennyi állampolgárának az összessége, míg a kultúrnemzet fogalmát olyan közösség megjelölésére használják, amelyekre a tartós együttélés és a közös történelmi múlt mellett, a területi, nyelvi, kulturális egység, és a kultúrában megnyilvánuló közös értékrendek a jellemzőek (KOVÁCs Z. 2015).

A nemzet fogalmának kettősége miatt, a nemzetiség fogalma is eltérő Nyugat- és Kelet-Európában. A nemzetiség fogalma nyugaton alapvetően állampolgárságot jelent, ugyanakkor Kelet- és Közép-Európában föként nemzeti kisebbség értendő alatta, vagyis az adott ország területén élö, de nem a többséghez (névadó nemzet), hanem a kisebbséghez tartozó egyének csoportja, mindemellett kontextustól függően etnikai csoportot is jelölhet a fogalom (BAJMÓCY P. 2004). Míg Nyugat-Európában az a felfogás terjedt el, miszerint egy nemzet körét az azonos állampolgársággal rendelkező egyének alkotják, addig KeletEurópában a nemzet fogalma leginkább az etnikum fogalmához közeledett (BAJMÓCY P. 2004). Ezen megközelítések szerint egy társadalmi csoporton belül általánosságban kisebbségnek azt a kisebb létszámú csoportot tekintjük, amely valamilyen ismérv alapján különbözik a többségtől, ezen ismérv alapján leggyakrabban etnikai, nemzetiségi, nyelvi, vallási kisebbségekről beszélünk (A. GERGELY A. et al. 2004). Mindemellett, egy kisebbségi csoportot a közös történelmi múlt, az ebböl fakadó magatartásbeli sajátosságok, valamint az összetartozás tudata köt össze (KoCSIS K. 2002).

Az etnikai földrajzi tényezőket figyelembe véve Kocsis (2002) nyomán, a kisebbségeket több szempontból osztályozhatjuk. A kisebbségi csoportokat etnikai területük jellege (pl. kompaktság, diaszpóra-jelleg) alapján megkülönböztethetjük az anyaország megléte, vagy ennek hiánya, illetve az anyaország földrajzi fekvése és az államhatárhoz való viszonya alapján. Ezen osztályozás alapján a következő csoportokat különíthetjük el: azon kisebbségek, melyek anyaországuk szomszédságában, viszonylag kompakt etnikai területen élnek; kisebbségek, melynek anyaországa (szárazföldön) nem szomszédos az adott álammal, de viszonylag kompakt etnikai területen élnek; anyaországgal nem, de kompakt, államhatár(ok) által két vagy több részre felosztott etnikai területtel rendelkező kisebbségek; anyaországgal nem, de egy állam keretein belül elhelyezkedö, többnyire kompakt jellegü etnikai területtel rendelkező kisebbségek; anyaországgal rendelkező, szórványban, diaszpórában élö kisebbségek; anyaországgal nem rendelkezö, apró nyelvszigetekben, szórványban, diaszpórában élö kisebbségek (KoCsIs K. 2002).

A kisebbségeket eredetük, származásuk alapján autochtonokra (őslakosokra), és allochtonokra (jövevényekre, újonnan érkezettekre) tagolhatjuk (KOCSIS K. 2002). Az autochton kisebbségek tagjai helyben maradtak, de valamilyen külső hatás révén kisebbséggé válták (KOVÁCS Z. 2015). Az allochton kisebbségek pedig vándorlás révén „alakultak ki”, amely vándorlás történhet szabad elhatározásból (döntően gazdasági megfontolásból), menekülés következtében (pl. politikai kényszer), illetve erőszakos betelepítés során (KovÁCS Z. 2015). Itt megjegyezendő, hogy Kárpát-medencei magyar kisebbségi közösségek autochton kisebbségnek számítanak (PAPP Z. A. 2014a).

\subsubsection{A szórvány meghatározásának dilemmái}

A diaszpóra helyzete széles körü népességre és történelmi helyzetekre terjed ki (Clifford, J. 1994; BRUBAKER, R. 2005). Több kutató is foglalkozott a szórvány megfogalmazásának módszertani dilemmáival és az ezzel kapcsolatosan felmerülő tudományos problémákkal, kategórizációs kérdésekkel. A szórvány kifejezés fogalma, és demográfiai operacionalizálása nem egységes (PAPP Z. A. 2016; ILYÉS, Z. 2007). Abban azonban közmegegyezés van, hogy a szórványhoz kapcsolódó legfontosabb fogalmak a 
asszimiláció és a migráció, amely folyamatok hatására a szórványhelyzet kialakul (TÁTRAI P. 2017b). A szórvány nehezen definiálható, hiszen nagyon sokrétủ és komplex fogalom, ezért lehetetlen egy mindenki által elfogadott meghatározást találni, napjainkig sem alakult ki közmegegyezés arról, hogy pontosan mely jellemzök alapján beszélhetünk szórványról (BICZÓ G. 2005). Ehhez kapcsolódóan Szilágyi N. Sándor megfogalmazását idézem, amely jól érzékelteti a szórvány kifejezés problematikáját: „én a szórvány (magyarság) megnevezést az alábbiakban a legszívesebben elkerülném. Ennek oka az, hogy - bármilyen meglepő is tapasztalatom szerint senki sem tudja pontosan megmondani, mit kell rajta érteni" (SzILÁGYI N. S. 1997).

Eredetileg a magyar szórvány kifejezésnek megfelelő görög eredetű diaszpóra szó bibliai eredetü, és szétszórtságot, szórványt jelent, és e terminust elsősorban az zsidó, görög és örmény közösségek megnevezésére alkalmazták (ILYÉs Z. 2011; BODÓ B. 2007; TÓTH PÁL P. 2005). Később e kifejezés szélesebb értelmü tartalommal egészült ki, és napjainkban a diaszpóra fogalmát általában a migrációs folyamatok következményeként, kisebbségi léthelyzetbe kerülő etnikai csoportok megnevezésére használják (BICZÓ G. 2007).

A magyar közbeszédben és a tudományos szóhasználatban is, a magyar vonatkozású szórványokra egyedi módon megkülönböztetik a „diaszpóra” és a „szórvány” fogalmát (BALOGH B. et al. 2007). A földrajztudomány, a diaszpóra megnevezést a vállalt, vagy kényszer hatására történő migráció következtében idegen országban kisebbségi csoportként élők megjelölésére használja. Addig a szórvány kifejezés, egyfajta belső fogalmomként, elsősorban a határváltozások következtében helyben kisebbséggé váló, „szétszórtan”, más etnikumokkal vegyesen élő magyarok megjelölését jelenti (KEMÉNYFI R. 2005; ILYÉS Z. 2011). A szórvány kifejezést, tehát elsősorban a történeti Magyarországnak a trianoni békeszerződés következtében utódállamokhoz került részein nem többségben, hanem más etnikumú csoportokkal vegyesen, kisebbségben élő magyarok helyzetére használjuk (BoDó B. et al. 2007). „A Kárpát-medencei összmagyar diskurzusban, egyfajta „hallgatólagos” közmegegyezés szerint minden szórvány, ami nem a tömbmagyarsághoz tartozik, amelyet bizonyos diszperzió, térbeli keveredettség jellemez" (ILYÉs Z. 2005b, p.145.), mindemellett a szórvány egyfajta határhelyzetet is jelent (BODÓ B. 2006).

A határhelyzet fogalmát a nyelvhatárral is összekapcsolhatjuk, hiszen a nyelvhatár az a térbeli választóvonal, amelyen túl az adott nyelv szórványba kerül, vagyis az adott nyelvet beszélő közösség „előfordulásának utolsó vonala” (FARKAS GY. 2000). Ilyés véleménye szerint a határrégiókban, kontaktzónákban, olyan kisebbségi csoportok alakulnak ki, amelyeknek tagjai egyidejüleg „több világban” képesek (kénytelenek) élni, ez számukra egyidejüleg előnyként (többnyelvüség, multikulturalitás), és hátrányként is megélhetik (elöítéletek, félelem az idegenektől) (ILYÉs Z. 2004; ILYÉS Z. 2008). A határrégiókat gyakran a kulturális stílusok keveredéséből adódó átmeneti kultúrák helyszínekét is értelmezik (ILYÉS Z. 2008).

Összegezve, míg a fenti megfogalmazások szerint a diaszpóra fogalmában, erőteljesen megjelenik a „szétszóratás”, a vándorlás, az eredeti helyről való elkerülés momentuma, addig a szórvány fogalomban a helyben maradás, a maradék-jelleg, a felmorzsolódás, és a regresszió kap hangsúlyos szerepet (ILYÉS Z. 2011). Keményfi véleménye szerint, habár az autochton (szórvány) és allochton (diaszpóra) felosztás eligazítana e kifejezések tartalma között, több esetben ez az elkülönítési elv megkérdőjelezhető lenne, hiszen példának okáért megemlíti, hogy másként szórvány egy mezőségi magyar református, mint egy 19. században odatelepült katolikus magyar közösség (KEMÉNYFI R. 2005).

Módszertani szempontból nincs pontos meghatározás, hogy milyen nagyságú népességet tekintünk szórványnak egy településen, illetve egy régión belül. Ezzel 
kapcsolatban eltérő vélemények alakultak ki, amelyek országonként változnak (MIRNICS K. 2003). A szórvány meghatározásánál, általában figyelembe kell venni a magyar népesség abszolút számát, százalékos arányát, a többségi etnikum (ok) nagyságát, a település/mikrorégió nagyságát, valamint a térbeli szétszórtság mértékét is (ILYÉS Z. 2011; TÁTRAI P. 2017b).

Ilyés Zoltán munkájában a szórvány legáltalánosabb meghatározás szerint a községek, falvak vonatkozásában a 300 fő jelenti a határt, amely alatt szórványról beszélünk, az arány tekintetében a 30 százalékot tekinti elfogadottnak (ILYÉS Z. 2011). Mindamellett említést tesz arról, hogy Schneller Károly a 25 százalékot és a 200 fót (1943), mások a 10 százalékot tekintik az igazi szórvány relatív értékhatárának (ILYÉS Z. 2011). Tátrai (2017b) tanulmányában, ahol a Kárpát-medencei magyar szórványok településszerkezetét vizsgálja, különböző szerzők munkáira hivatkozva (DÁNYI D. 1999; GYURGYÍK L. 2006; GYURGYíK L. HorvÁth I. - KISS T. 2010; MolnÁr J. - MOlnÁr D. I. 2005; KISS T. - BARNA G. 2012; Bodó B. 2014; VetÉSI L. 2000; GÁBRITY MOLNÁR I. 2005a; SEBÖK L. 2005; BADIS 2011) a szórvány kvantitatív határának leggyakrabban használt küszöbeként említi az 1 százalékos, a 10 százalékos, a 20 százalékos, és a 30 százalékos arányt (TÁTRAI P. 2017b). Ezen abszolút és relatív mennyiségi mutatók miatt változatos nagyságú és helyzetü csoportok sorolódhatnak a szórvány kategóriába, de természetesen nem csak a települési arány a döntő tényező a szórvány definíciójának meghatározásakor (ILYÉS Z. 2011). A szórvány értelmezése és lehatárolása során a települési arány mellett érdemes területi szempontokat is figyelembe venni. Ezen megközelítés szerint szórványnak tekinthetjük azokat a területeket és településeket, amelyek nem tartoznak a területileg egybefüggő, többnyire magyar többségü településekből álló tömbökhöz (TÁTRAI P. 2017b).

Különböző ismérvek alapján szórványtípusokat különíthetünk el, melynek csoportosítását végezhetjük a szórvány elhelyezkedése, társadalmi-gazdasági helyzete, integrációs-asszimilációs szintje, önkép, önreprezentáció, illetve veszélyeztetettség alapján is (ILYÉS Z. 2011). Kialakulásuk szerint különbséget tehetünk az autochton és allochton szórványok között. Autochton szórványközösségeknek azok a csoportok tekinthetők, amelyek helyben laknak, az allochton szórványközösségek pedig többnyire telepítések során kerültek a térségbe, példaként említhetjük a történelmi Délvidéket, ahol török hódoltság után számos kincstári és magánföldesúri telepítés, és önkéntes település zajlott (ILYÉS Z. 2011).

A településhálózat különböző nagyságú, hierarchiaszintű egységeiben való jelenlét alapján is osztályozhatjuk a szórványokat. Megkülönböztethetjük a falusi, helyenként tanyai, városi, kisvárosi-nagyvárosi szórványokat (ILYÉS Z. 2011). A településtérben megfigyelhetö mintázat alapján beszélhetünk szigethelyzetü szórványokról, ahol a magyarság létszáma gyakran meghaladja a szórvány mennyiségi kritériumát, mégis a más etnikumú többségi környezet miatt szórvány besorolást nyernek. Diszperz helyzetű az a szórványvidék, ahol viszonylag egyenletesen szétszórt helyzetben találjuk, tömb-peremi helyzetü szórvány esetében pedig az etnikai tömb peremén „lemorzsolódó, erodálódó” közösségről van szó. A legkisebb töredékcsoportokra a „foszlánymagyarság” kifejezést is alkalmazzák (VETÉSI L. 2000; ILYÉs Z. 2011).

Ilyés Zoltán munkájában leírtak szerint a szórványokat osztályozhatjuk továbbá, integrációs-asszimilációs szintjük szerint is, azaz érzékelhetők a kulturális, etnikai, nemzeti beolvadás különböző fokozatai. A kisebbségben élök, a többségi (és más) közösségtöl, számos kulturális elemet „kölcsönözhet”, de át is adhat egyes kultúrelemeket (ILYÉS Z. 2011). A társadalomtudományok azt a folyamatot, ahol a társadalmi csoportok egy más kultúrával való érintkezés révén átveszik annak kulturális elemeit, akkulturációnak nevezik (ILYÉs Z. 2011). Yinger írásában (YINGER, J. M. 2002) az akkulturáció fogalmát Spicer munkájára 
(SPICER, E. H. 1968) hivatkozva két vagy több csoport kapcsolatából eredő folyamatnak tekinti, és kiemeli, hogy e jelenség a kulturális hasonlóság növekedése felé halad. Mindemellett hozzáteszi, hogy néhányan két kulturális csoporttal is azonosulnak, de gyakran előfordul, hogy helyzetüket mindkettőben marginálisnak érzik, ilyenkor az egyén „két világ határán" reked (YINGER, J. M. 2002).

Itt ki kell emelni, Bodó megfogalmazását, miszerint a szórvány asszimilációra hajlamosító közeg, illetve folyamat, a végeredményt nevezhetjük kultúraelhagyásnak vagy akár etnikai adaptációnak (BODÓ B. 2003). Térségünkben legnyilvánvalóbban a nyelvváltással jellemzik az asszimilációt, melyhez hozzá kell füzni, hogy ez többlépcsős folyamat, amelyben a nyelvváltás az egyik ilyen lépcsőfok, és szórványban ez következik be hamarabb, míg az etnikus tudat tovább fennmarad (ILYÉs Z. 2011; RADó P. 1996).

Általánosságban kijelenthető, hogy a szórványközösségek többsége kétnyelvü, ami az anyanyelv domináns kétnyelvüségtöl, a majdnem teljes nyelvcsere állapota közötti többféle nyelvállapot jellemző rájuk (ILYÉS Z. 2005a). A szórványban az anyanyelv használatának természetességét felülírják a környezeti hatások, egyre fontosabbá válnak más közösségek nyelvi és kulturális szemléletei, aminek eredményeként az egyén életében és kapcsolataiban a másik, a kulturálisan domináns közösség válik meghatározóvá, egyfajta hangsúly eltolódásról beszélhetünk (BoDÓ B. 2006, p.24.).

A vajdasági szórványosodó településekre vonatkozóan, Mirnics 2003-ban írt tanulmányában négy kategóriába osztotta ezen településeket (MIRNICS K. 2003). A lehatárolás során föként demográfiai, és intézményi jellemzőket vett alapul. Az első kategória szerinti településeknek 1991-ben és 2002-es évben is volt magyar tannyelvü iskolája, müvelődési és közéleti intézménye, de a születési arányszám nem volt elég a népességreprodukcióhoz; Második kategória: megszünt a magyar tannyelvü oktatás, de még vannak a magyar közösség által müködtetett müvelödési, és közéleti intézmények; Harmadik kategória: megszüntek a művelődési és közéleti intézmények, de az ott élők továbbra is igénylik ezen intézmények szolgáltatásait a magyar kisebbség nagyobb központjaiból; Negyedik kategória: a kisebbségi közösségi élet megszűnt, csupán az egyénekre korlátozódó, esetenkénti egyházi szertartás igénylése (MIRNICS K. 2003).

Véleményem szerint a Vajdaságban minden olyan területet szórványnak tekinthetünk, amely nem a tömb része, viszont az empirikus kutatást szempontjából szükségesnek tünt egyfajta számarányt is figyelembe venni a mintaterületek lehatárolása során, ezért Gábrity Molnár Irén szórvány meghatározását vettem tekintetbe, miszerint a „szórványmagyarság fogalmán általában a határon túli magyarságnak azt a rétegét értjük, amely a többségi nemzetekhez képest településén, mikro régiójában 30 százaléknál kisebb arányban él, hátrányos nyelvi, etnikai, vallási helyzetben és a nemzettesttől elszigetelődve, leépült intézményrendszerrel, folyamatos veszélynek, felszámolódásnak van kitéve" (GÁBRITY MOLNÁR I. 2005a, p.24.).

\section{Kutatási előzmények}

A Kárpát-medencei magyar szórványok témaköre a rendszerváltás után került ismételten a tudományos kutatások fókuszába (TÁTRAI P. 2017b). Később a 2000-es évektől kezdve a szórványkutatás aktuális feladatait és irányait illetően egyre több konferenciát, szimpóziumot és kutatást szerveztek össz Kárpát-medencei szinten. Többek között ezen konferenciák és kutatások foglalkoztak a szórvány meghatározás dilemmáival, a szórványközösség mindennapjait érintő kérdéssekkel, mindemellett foglalkoztak a 
szórványközösségek nyelvvel, nemzettel és az interetnikus együttéléssel kapcsolatos kulturális magatartásáról is. Összegezve, ezen konferenciák alkalmával igyekeztek felhívni a figyelmet a szórványban élök helyzetére. A szórvány utáni érdeklődés oly annyira megnőtt, hogy a Magyar Állandó Értekezlet szórvány szakbizottsága 2013 májusában határozatot hozott, mely szerint november 15-e a magyar szórvány napja. Mindemellett a tudományos intézmények (pl. Társadalomtudományi Kutatóközpont - Kisebbségkutató Intézet, Magyar Tudományos Akadémia Etnikai-Nemzeti Kisebbségkutató Intézete, „Határon Túli Magyar Kisebbségek" kutatócsoportja) kutatási irányai is mind nagyobb figyelmet szenteltek a szórvánnyal kapcsolatos témák iránt. Ehhez kapcsolódóan érdemes kiemelni, hogy a vajdasági Magyar Nemzeti Tanács a magyar szórvány napját beemelte a vajdasági magyarság ünnepnapjai és jeles napjai sorába, amely azt igazolja, hogy egyre nagyobb figyelem fordul a szórvány területek és közösségek felé a Vajdaságban is.

A szórványra vonatkozó nemzetközi és hazai szakirodalmat oly módon kell megkülönböztetni, hogy a nemzetközi szakirodalom többsége azon diaszpóra közösségeket vizsgálja, akik maguk vándoroltak (önszántukból vagy kényszer hatására) egy bizonyos területre. Ezen vizsgálatok középpontjában kiemelkedően a beilleszkedés, az integráció, és a nyelvi akadályok leküzdése áll. Míg a magyar szakirodalom a külföldön élő diaszpóra közösségek mellett, elemzi a Magyarország határain túl élő magyarságot, az úgynevezett „belső szórványt”.

\subsection{Kutatások a Kárpát-medence régióiban}

A dolgozatban a kutatási előzményeket oly módon csoportosítom, hogy elöször a Kárpát-medence magyar nemzetiségüek által lakott régióiban készült főbb kutatások eredményeit ismertetem, ezt követően pedig a vajdasági magyar szórványról szóló elemzéseket foglalom össze.

A határon túli magyarság körében (erdélyi, felvidéki, kárpátaljai, és vajdasági magyar közösségek) a Balázs Ferenc Intézet 1996-ban kutatást végzett, amelyet 2011-ben a B-Fókusz Intézet és a KárpátPress kutató csapata megismételt (DOBOS F. 2011). Mindkét kutatás a határon túli magyarság körében jelentkező asszimilációs folyamatokat kutatta, amely vizsgálat kiterjedt az említett közösség anyanyelvhasználatára, anyanyelvi oktatására, és nemzeti identitásához való viszonyára is. A regionális és idősoros összehasonlítást tartalmazó elemzés során összesen 4476 fö vett részt a kutatásban, ebböl 3285 fö gyermekeit magyar nyelven, míg 1896 fő gyermekét többségi iskolába, az adott állam nyelvén, államnyelven tanítatta. A kérdőíves adatfelvétel során a kutatásban részt vevő szülők, döntő többségükben magukat magyar nemzetiségünek vallották, és a lekérdezés időpontjában volt óvodába, illetve általános iskolába járó gyermeke vagy gyermekei (DOBOS F. 2011). A kutatás eredményeit a kutatási jelentés zárta: Asszimilációs folyamatok az erdélyi, felvidéki, kárpátaljai és vajdasági magyarság körében 1996-2011 címmel. Az eredmények szerint másfél évtized során a vizsgált régiókban az intergenerációs (családon belül „öröklődő”) iskolaválasztás vonatkozásában megfigyelhető, hogy a magyar iskolát végzett szülők gyermekeik számára (a Vajdaság kivételével) kisebb arányban választanak anyanyelvi oktatást, mint tették azt másfél évtizeddel azelőtt. A korábbi kutatás során részben, vagy teljesen többségi nyelvü oktatásban részesültek körében, pedig jelentősen tovább növekedett az ukrán, szerb és a román iskolát választók részaránya, a szlovák tannyelvü iskolát választóké pedig a korábbi magas szinten stagnált (DoBos F. 2011). Mindemellett, a kutatás rámutatott, hogy az államnyelvű iskolát választó kisebbségi gyökerekhez tartozó családokon belül egyre fokozódó többségi nyelvhasználati gyakorlatról is beszélhetünk (DoBOs F. 2011). 
Fontos továbbá kiemelni Gereben Ferenc kultúrszociológiai munkáját is (1999), amely empirikus kutatásra támaszkodva vizsgálta a határon túli magyarság identitástudatát, és a kultúrához való viszonyát (GEREBEN F. 1999). E két nagy témához kapcsolódva a következő témakörökkel foglalkozott: értékrend és értékszemlélet kérdése, nyelvhasználat, vallási identitás, kulturális magatartásmód (olvasási szokások témaköre). Munkájában a nyelvhasználat és nyelvválasztás témájának kutatásakor kitért az iskolai tannyelv kutatására is, ahol az iskola nyelvének megválasztását is vizsgálta. Az eredmények szerint az általa megkérdezett személyeknek mintegy fele folytatta tanulmányait végig anyanyelvén, további, körülbelül 40 százalékuk pedig vegyes nyelvhasználattal (anyanyelven és államnyelven) járta ki iskoláit, míg 5-10 százalékuk végig államnyelven tanult (GEREBEN F. 1999). A kutató hozzáteszi, hogy nem mindegy, hogy milyen magas fokozatig jut el az iskolázottsági folyamat, amelyet a válaszadók „végig” magyarul végeztek el. Kifejti, hogy e kategória többnyire általános (alap-) iskolai vagy gimnáziumi (líceumi) végzettséget takar. A főbb eredményeket a kutató a következöképpen foglalta össze: az anyanyelven végzett tanulmányok lehetőségével föként a tömbszerüen együtt élő magyar közösség rendelkezik, míg a vegyes tannyelvü, illetve államnyelvü oktatásban a szórványterületen élők, és a városokban lakó közösség vesz részt (GEREBEN F. 1999).

A szorosan a kutatáshoz kapcsolódó előzmények közül, az iskolaválasztást társadalmi összefüggésében vizsgáló felméréseket kell megemlíteni, amelyek a Kárpát-medence magyar nemzetiségüek által lakott régióiban a 2012-es és a 2013-as évben készülttek. Ezen kutatások Papp Z. Attila és Bodó Barna vezetésével kerültek megszervezésre, amelyek tömb- és szórványterületen vizsgálták a magyar kisebbségek körében a többségi- és kisebbségi tannyelvválasztást. A kutatás során elsősorban az érintettek (szülők, diákok) motivációit vizsgálták, és ezekből a motivációkból kiindulva vizsgálták a tannyelvválasztási döntéseket (PAPP Z A. 2012b; PAPP Z A. 2013; Bodó B.-MÁrton J. 2012; FERENC V. - SÉRA M. 2012; Morvai T.-SZARKa L. 2012; MÁRton J. 2013; Bodó B. 2013; RAVASZ Á. 2013; Morvai T. 2013; SZÜGYi É. 2012; SzÜGYI É. 2013; Trombitás T. 2013; FERENC V. 2013; SÉRA M. 2013). A kutatások eredményei közül azt emelném ki, hogy a többségi iskolaválasztásra befolyásoló hatással van a vegyes házasság, a szülök iskolai végzettsége, és a társadalmi-gazdasági helyzet (PAPP Z. A. 2014b).

Kutatásomhoz kapcsolódik Bartha Zsuzsanna munkája, ahol az iskolaválasztással összefüggő döntések magyarázatait kutatta. Munkájának központi kérdése, hogy a tannyelvválasztás mögötti érvek mennyiben pragmatikus, cél racionális vonatkozásúak (például az oktatás költségei, színvonala, várható haszon stb.), és mennyiben tartalmaznak a magyar identitás és anyanyelvhez köthető értékelkötelezettségre utaló elemeket (BARTHA ZS. 2014).

Erdei Ildikó doktori értekezésben szintén a többnyelvü környezetben élő gyerekek nyelvi szocializációját vizsgálta. Munkája során külön figyelmet fordított a „nyelvileg” vegyes családokban élő gyermekek nyelvi szocializációjára, valamint a családi és intézményi kétnyelvüvé válás körülményeinek felkutatására, továbbá kutatta a pedagógusok nézeteit is, a kétnyelvüséggel kapcsolatban (ERDEI I. 2010).

Rendkívül hasznos információforrásként szolgáltak kutató munkám során Fodor Dóra esettanulmányai, melyet Aranyosgyéresen és Tordán készített (FODOR D. 2005a; FODOR D. 2005b). Munkája során feltárta, hogy egy nyelvcsere felé haladó családban a nyelvek presztízse, a nyelvi attitüdök hogyan befolyásolják a nyelvhasználatot és az identitást. E kutatásban egy család három tagja vett részt, a kutatás 1998-ban készült, majd 2003-ban a kutató ismét felkereste a családot. Eredményei szerint egy család nyelvcseréjét nagymértékben befolyásolja a szülői modell, és a családot jellemző belső, pszichikai kötelékek. Mindemellett az olyan külső tényezők, mint a munkahelyi környezet, a 
szomszédok, a barátok, a szétszórtság (szórvány), a magyar nyelvü óvoda és iskola hiánya fontos szerepet játszottak abban, hogy elindult a nyelvcsere folyamata (FODOR D. 2005a). Egy másik helyszínen, Tordán végzett komparatív elemzése során pedig azt a célt tüzte maga elé, hogy 15 etnikailag homogén házasságból származó magyar tagozaton tanuló diák nyelvhasználatát, nyelvi attitüdjeit összehasonlítsa 13 magyar-román vegyes házasságból származó magyar és román tagozaton tanulóval. Továbbá megvizsgálta a fiatal generáció identitásképletének alakulását, megfigyelte, milyen jellegzetes tényezők járulnak hozzá a gyermekek anyanyelvi és nemzetiségi hovatartozásának megválasztásához. Az általa gyüjtött adatok szerint, a vegyes házasságokban a kisebbségi nyelv megmaradásában és átörökítésében fontos szerepet játszik a gyermekek iskolázásának nyelve, vallási hovatartozása, valamint e tényezők mellett fontos még az anya nemzetisége és anyanyelve (FODOR D. 2005b). A kutató viszont hangsúlyozza, hogy következtetései nem tekinthetők általános érvényünek, mivel viszonylag kis létszámú minta került a kutatásban, és csupán egy iskolában történt a felmérés (FODOR D. 2005b).

Árendás Zsuzsanna tanulmányában az iskolaválasztás körülményeit DélnyugatSzlovákia két vegyes lakosságú területén, a Galántai és a Vágsellyei járásban vizsgálta. Munkájában elemzi a szülők elvárásait, az iskolaválasztás és (társadalmi) siker összefüggéseit, valamint az iskolaválasztás egy sajátos aspektusára, a gender (társadalmi nem) lehetséges szerepére hívja fel a figyelmet (ÁRENDÁs Zs. 2012). A kutató összegzésként arra a megállapításra jutott, hogy míg a homogén etnikai kötődésekkel rendelkezők automatikusan választanak iskolát gyermeküknek, addig a kettős etnikai kötődésekkel rendelkezők esetében nincsenek ilyen kész válaszok az iskolát illetően. Mindemellett, az empirikus kutatás azt igazolta, hogy az oktatási nyelv megválasztásakor többségében nem etnikus szempontok érvényesülnek, hanem egyéb, nem-etnikus tényezők játszanak szerepet a döntésben, úgy mint a siker, a társadalmi érvényesülés, az elismerés és a mobilitás. A kutatás rávilágít, hogy a „többes etnikai kötődéssel rendelkező családok jelentős része, kilépve a nemzeti-etnikai kritériumrendszerből, nem etnikus szempontok szerint választ iskolát, és igyekszik gyermekét a siker, a társadalmi érvényesülés útjára terelni” (ÁRENDÁs Zs. 2012, p.12.).

Badis Róbert által vezetett zentai Identitás Kisebbségkutató Mühely szórványstratégiai javaslatot készített a vajdasági területre vonatkozóan. A stratégiában összesen kilenc célt fogalmaztak meg, amelyek a következők: a magyar anyanyelvü oktatás megörzése a szórványterületeken; a kisebbségi családtámogatási rendszer kialakítása; a müvelődési élet felélénkítése és fejlesztése; a politikai képviselet biztosítása; a gazdasági befektetések szórványba kanalizálása; az asszimiláció folyamatának lassítása és megállítása; a szórványban élő magyar közösségek integrációja a magyar nemzetbe; a szórványközpontok létrehozása; az egyházak nagyobb szerepvállalása a szórványgondozásban. Mindemellett itt kell megjegyezni Tóth-Glemba Klára, a vajdasági szórványmagyarság közösségét érintő igények szakterületek szerinti feltárását célzó munkáját is (TóTH-GLEMBA K. 2005).

A vajdasági magyar közösség tannyelvválasztásával kapcsolatban Szügyi Éva elemzéseit kell megemlíteni, amely kutatómunkámhoz a legszorosabban kapcsolódik. Szügyi a már említett Kárpát-medencét átfogó tannyelvválasztás motivációira irányuló kutatások során a vajdasági szórvány- és tömbterületeken végzett felmérést. Eredményei szerint az iskolaválasztással illetve oktatási nyelvvel kapcsolatos döntéshozatal etnikai mozzanata (etnikai alapon történő tannyelvválasztás) elhanyagolható azokban a régiókban, amelyekben a kisebbség aránya elenyésző, ahol a gyermekek már hiányosan beszélik anyanyelvüket, vagy már nem is beszélik azt, illetve az anyanyelvü oktatás sem elérhető (SzÜGYI É. 2014). Mindemellett azokban a régiókban is elhanyagolható a döntéshozatal etnikai mozzanata, amelyekben a kisebbségi nemzet többséget alkot (egy tömbben él), ahol bárki számára adott 
az anyanyelvü oktatás lehetősége és akár több oktatási intézmény közül is választhat a szülő (SZÜGYI É. 2013). A Vajdaságban a többségében magyarok lakta területeken, ahol az óvodától a középiskoláig biztosított a magyar tannyelvü oktatás, a legtöbb szülö számára természetes, hogy a gyerekeket anyanyelvükön taníttatják (SzÜGYI É. 2012). Itt a szülő döntését praktikus kérdések befolyásolják, úgy mint a saját tapasztalat az intézménnyel kapcsolatban, az iskola távolsága az otthontól, a biztonságos közlekedés, hogy hova jár az idősebb testvér, stb. Ennek következtében a többségi nyelvü iskolaválasztást különbözőképpen kell értelmezni a tömbben és a szórványban, ugyanis a tömbben akár több anyanyelvű oktatást is folytató iskola közül is lehet választani, míg a szórványban sok településen nem áll rendelkezésre kisebbségi nyelvü oktatás (SzÜGYI É. 2012). Kiemeli továbbá, hogy magyar nemzetiségü családokból származó gyermekek boldogulására a szerb nyelvü tagozatokon pozitív és negatív példát egyaránt lehet találni, azt viszont ki kell hangsúlyozni, hogy a sikerhez elengedhetetlen, hogy a gyermek már meglévő nyelvtudással iratkozzon be az iskolába, és ne az első osztályban ismerkedjen meg az államnyelvvel (SzÜGYI É. 2012). Összegezve, éles határvonal húzható a tannyelvválasztást befolyásoló tényezők között a tömbmagyarság területén és a szórvány területeken, továbbá ezen belül is más tényezők hatnak a kisebbségi (magyar) tannyelvválasztásra, mint a többségire (szerb). Míg a kisebbségi tannyelvválasztását a tömbben racionális tényezők motiválják, addig a szórványban érzelmi tényezők (pl. a kisebbségi kultúra fennmaradása). A többségi tannyelvválasztásnak külön figyelmet kell szentelni a kutatások során, a tannyelv ugyanis bizonyítottan befolyásolja a gyermek későbbi iskolai életútját (SZÜGYı É. 2014).

Hajnal Virág és Papp Richárd a vajdasági tömbmagyarság és a szórvány kulturális különbségeiröl írnak, amely föleg a nyelvhasználat terén mutatkozik meg. Kutatásukban egy szórványtelepülés, a szerémségi dobardósi mikro-társadalom tagjainak nyelvválasztási stratégiáit vizsgálják. A kétnyelvü közösség mindennapjaik során a magyar, a szerb és a horvát nyelvet is használják, a kutatás egy példája lehet egy közösségben zajló nyelvcsere vizsgálatának (HAJNAL V. - PAPP R. 2005). Ezen felül több kutatásuk is foglalkozott a Vajdaságban élő magyar kisebbség kultúrájával, identitásával és nyelvhasználati szokásaival, amely tanulmányok főként a kulturális antropológiai kutatások közé sorolhatók (HAJNAL V. 2003a; HAJnal V. 2003b; HAJnAL V. - PAPP R. 2004; HAJnAL V. - PAPP R. 2007; HAJnAL V. - PAPP R. 2008).

Egy az 1990-es években készült tanulmányt is érdemes kiemelni, hiszen már akkoriban is foglalkoztak a vajdasági kisebbségeket érintő tannyelvválasztási problémákkal. Bálint Sándor 1991-ben megjelent tanulmányában többek között azzal is foglalkozik, hogy Vajdaságban miért járnak az egyes nemzetiségi tanulók szerbhorvát tannyelvü iskolába olyan esetekben is, amikor lehetőségük van az anyanyelvü képzésre. Felhívja a figyelmet arra, hogy a magyar nyelvü szaktanárok hiányát sok esetben, főleg a szórványban, az iskolák a szerbhorvát tagozatokon tanító tanárok bevonásával igyekeznek megoldani, ezért a kisebbségi tannyelven tanulók, több esetben államnyelven hallgatják az óráikat. Külön gondként említi meg a szaktárgyukat szerbhorvát nyelven tanult tanárok problematikáját, akik, véleménye szerint, olykor „kerékbe törve” beszélik a kisebbségeket érintő tanítási nyelvet. Véleménye szerint a tanítási nyelv nem megfelelő minőségü használata kedvezőtlenül befolyásolja a tantárgyak oktatási eredményeit, és nehézségeket okoz az anyanyelv tanításában (BÁLINT S. 1991). A tanulmány szerzője szerint, több szülő, azért választja az államnyelvü oktatást, mert sokszor nem találnak olyan pedagógust, aki a kisebbség nyelvén tanítana, illetve a szülök a könnyebb boldogulás reményében íratták gyerekeiket szerbhorvát tannyelvü iskolába. Rámutat továbbá, hogy a fokozatosan fogyó diákok miatt kérdésessé válik a nemzetiségi tannyelvü iskolai tagozatok müködtetése (BÁLINT S. 1991). 
Továbbá hangsúlyozni kell, hogy a Vajdaság területén több kvalitatív kutatás történt, amelynek nagy részét a Magyar Nemzeti Tanács készítette, igen hasznos eredményekkel. Itt szeretném ismertetni Joó Horti, Mengyán Pletikoszity, Csernik és Badis tanulmányát. A kutatás során magyar nemzetiségü elsős tanulók nyelvi kompetenciáját vizsgálták, amely gyermekek szerb tagozatra jártak, olyan önkormányzatokban, ahol rendelkezésre állt a magyar nyelvű oktatás is. A kutatást a 2013/2014-es iskolaévben, főként kérdőíves módszert alkalmazva bonyolították le Vajdaság iskolában, de a kérdőívek elemzése mellett, a kutatás során interjúk is készültek. A kapott eredmények szerint, a kutatásba bevont 244 szerb tagozaton tanuló magyar nemzetiségü elsős 69\%-a (168 diák) egyáltalán nem érti, beszéli és használja a magyar nyelvet, 31\%-uk (76 diák) valamilyen szinten beszéli és használja, és mindössze 19,2\%-uk (47 kisdiák) ismerte olyan jól a magyar nyelvet, hogy akár magyar tannyelven is tanulhatott volna (JOÓ HORTI L. et al. 2014).

A felsorolt irodalmak alapján látható, hogy az utóbbi években több tanulmány is született a vajdasági magyarságot érintő oktatási helyzetről, illetve tannyelvválasztásról. Az Európai Unió bővülése, a globalizáció, a növekvő elvándorlás jelensége és a felgyorsult asszimilációs folyamatok mind szükségessé teszik az e témakörben megújuló kutatásokat, hiszen ezen folyamatok és tényezők mind kihatással vannak a többségi és kisebbségi nyelvek szerepére, valamint a beszélő közösség életére/társadalmára. Saját empirikus kutatásom abban különbözik a már meglévő kutatásoktól, hogy egyrészt társadalomföldrajzi szemszögböl vizsgálja az iskolaválasztás tannyelvhez füződő folyamatát, amely során hangsúlyos szerepet kap a szórványban élő magyar kisebbség társadalma, és a térbeliség tényezője is. Másrészröl vizsgálatomban a pedagógusok véleménye hangsúlyosan megjelenik, de kutatásom célját és kérdéseit a következő fejezetben részletesen kifejtem.

\section{A dolgozat célja és kérdései}

A szórványban élő magyar közösségek alacsony számbeli arányuk miatt sajátos társadalmi és szociokulturális környezetben élnek, emiatt egyedi érték- és normarendszert képviselnek. A társadalmi együttélés sajátos nyelvi (többnyelvü) környezetet teremt, ahol általános vélemény szerint a kisebbségek estében az iskolai oktatásban mindkét nyelv (az államnyelv és a kisebbség nyelve) egyaránt fontos, hiszen a kisebbség egészére vonatkoztatva az államnyelv hatékony elsajátítása kulcsfontosságú, hiszen ahhoz, hogy a kisebbségi közösség tagjai bekapcsolódhassanak a helyi felsőoktatásba, illetve, hogy képesek legyenek sikeresen jelen lenni a munkaerőpiacon, ennek mind előfeltétele az államnyelv megfelelő szintü ismerete, ami a szórványba adott. E mellett a kisebbség számára döntő fontosságú anyanyelvének ápolása/ismerete is, hiszen identitásuk megtartásának folyamatában a nyelv meghatározó tényező (M. CSÁSZÁR Zs. 2011).

Vetési szerint a Kárpát-medencében a kisebbségi sorban élök között a magyar nyelvü oktatás presztízsvesztése figyelhető meg (VETÉSI L. 1999). Göncz adatai (GöNCZ L. 2004) alapján a vajdasági szülök körülbelül 20-30 százaléka dönt a többségi (szerb) oktatás mellett, de e kérdésben hasonlóképpen döntenek a Kárpát-medence más határon túli magyar nemzetiségüek által lakott régiókban is (CSETE Ö. et al. 2009; CSERNICSKÓ I. - GÖNCZ L. 2009; ERDEI I. 2010). Mindemellett, szórványhelyzetben, a demográfiai zsugorodás is hatással van a magyar nyelv pozíciójára és használatára is (TÁTRAI P. 2017a).

A vajdasági szórványterületeken általánossá vált, hogy a szülők különböző megfontolásból gyermekeiket többségi (szerb) nyelven iskoláztatják annak ellenére, hogy biztosított a magyar tannyelvü oktatás (JOÓ HORTI L. et al. 2014). Vajdaságban, tehát a magyar nemzetiségü általános iskolások körülbelül 20 százaléka tanul szerb nyelven, viszont 
ezen belül egyes szórványtelepüléseken a szerb tannyelven tanuló magyar nemzetiségü diákok aránya az 50 százalékot is meghaladja. ${ }^{1}$ Nem szabad azonban figyelmen kívüil hagynunk azt a tényt sem, hogy a magyar gyerekek jelentős része azért tanul szerb tagozaton, mert nincs a közelben lehetősége anyanyelvén tanulni. Egy 2014-ben készült kutatás szerint a nem magyar nyelven tanuló magyar nemzetiségü diákok körülbelül 5\%-a él Vajdaság olyan területén, ahol már nem müködik magyar tannyelvü iskola, valamint iskolabuszokkal is elérhetetlen távolságban van a legközelebbi magyar osztály (JOÓ HORTI L. et al. 2014). Meg kell említeni, hogy Vajdaságban a Magyar Nemzeti Tanács több módon támogatja a magyar nyelven történő oktatást, beiskolázást, ilyen az ingyenes tanszercsomagok osztása, az iskolabusz program, illetve a különböző ösztöndíj lehetőségek a tanulók számára. Mindemellett tájékoztató körutak alkalmával és különféle projektek (pl. Újvidéki Magyar Oktatásért Projekt) keretein belül igyekeznek felhívni a magyar szülők figyelmét az anyanyelven történő oktatás fontosságára.

Kisebbségi léthelyzetben az oktatási nyelv megválasztásának kérdésköre bonyolult, és e téma vizsgálatakor különbséget kell tenni a tömb- és a szórványterületen élő magyar lakosság között. A tömbterületen tanuló magyar anyanyelvü diákok általában nagyon gyengén beszélik az államnyelvet, és ez gátolhatja a későbbi érvényesülésüket a szülőföldön, illetve a továbbtanulásukat nem érdeklődési körük szerint választják, hanem a magyar nyelven elérhető szakokhoz igazítják, vagy a Magyarországon történő továbbtanulás mellett döntenek (TAKÁCS Z. et al. 2014; TAKÁCS Z. et al. 2013; SZÜGYI É. - TAKÁCS Z. 2011). Ezzel ellentétben a szórványterületeken fordított a helyzet, hiszen a magyar nemzetiségüek szinte hiánytalanul kommunikálnak az állam nyelvén, míg saját anyanyelvük használata háttérbe szorul, és föleg csak a családi környezetre korlátozódik. A szórványban élöknek nem az a „gondjuk”, hogy hogyan sajátítsák el az államnyelvet, hanem az, hogy hogyan tartsák meg anyanyelvüket. Még bonyolultabbá válhat az oktatási nyelv megválasztása a vegyes nemzetiségü házasságokból született gyermekeknél, hiszen a szülőknek itt dönteniük kell egyik vagy a másik nyelv között.

Ehhez kapcsolódóan a kutatás általános célja az volt, hogy puha módszerek segítségével megismerjem azokat az egyéni szempontokat, motivációkat és háttértényezőket („mögöttes meghúzódó tartalmakat”), amelyek során a magyar kisebbségi kultúrához/gyökerekhez tartozó diákok és szülők a szerb tannyelvü iskoláztatás mellett döntöttek, továbbá nagyon fontosnak tartottam, hogy a pedagógusok véleményét is megismerjem az iskolát kezdő gyermekek tannyelvválasztási nehézségeiről.

A célom, tehát a szórványban élő magyar kisebbség iskola- és tannyelvválasztásával kapcsolatos nézeteinek a felkutatása. A célkitüzéshez kapcsolódó fő kérdés, hogy milyen egyéni, családi, kulturális, és mikroközösségi háttere van a magyar nemzetiségü szülők beiskolázási gyakorlatainak a szórványban? Ehhez kapcsolódóan további alkérdéseket fogalmazok meg: Milyen szempontokat vettek figyelembe az iskola megválasztásánál? Miként fogalmazzák meg az iskolaválasztással kapcsolatos döntéshelyzetet az etnikailag vegyes házasságban élők? Milyen társadalmi, gazdasági és térbeli körülmények befolyásolják az oktatási nyelv megválasztását egy szórványtelepülésen? Hogyan vélekednek a pedagógusok a tannyelvválasztásról?

Ha a disszertáció témáját el kellene helyezni a geográfia hagyományos rendszerében, akkor a kutatásom a társadalomföldrajzon belül, az etnikai földrajz és a kultúrföldrajz

\footnotetext{
${ }^{1}$ Oktatásfejlesztési Stratégia 2010-2016, Magyar Nemzeti Tanács
} 
metszéspontjában helyezkedne el, hiszen a kutatás az iskolai nyelvhasználat megválasztásán keresztül vizsgálja egy szórványterületen élő kisebbségi csoport hozzáállását, illetve dilemmáit a nyelvhez/kultúrához egy multietnikus közösségben.

A kutatás újszerüsége abból adódik, hogy egyrészt társadalomföldrajzi szemszögből vizsgálja a szórványterületen kisebbségben élők oktatási nyelv megválasztásához kapcsolódó körülményeit. A dolgozatban hangsúlyos szerep jut a szórványban élők társadalmának, és az ehhez kapcsolódó térbeli/lokális tényezők elemzésének is, illetve a pedagógusok véleménye kiemelten jelenik meg. A kutatás során felvetődnek mind földrajzi, mind pedig pedagógiai jellegü szempontok is. A vizsgálatnak nem célja, hogy állást foglaljon sem a többségi, sem a kisebbségi tannyelvü oktatás mellett. Az oktatási nyelv megválasztásával kapcsolatos döntés minden egyén esetében saját szubjektív elhatározáson alapul, hiszen minden családnak sajátos élethelyzete, háttere és körülményei vannak, ezáltal döntésüket teljes mértékben tiszteletben kell tartani.

A fentiekben leírtakhoz igazodva összegezném, hogy kutatásom középpontjában egy szórványközösség oktatási nyelvhez kötődő vizsgálata áll. E téma relevanciáját indokolja, hogy a rendszerváltást követően elötérbe kerültek a kisebbségek, és a velük kapcsolatos témakörök. Ezen kutatások egy része az 1989/90-es fordulat hatásait vizsgálja az oktatásra, az oktatást irányítókra és az oktatásban részt vevő társadalmi csoportokra, többek közt a kisebbségekre is (KozMA T. 2003). Továbbá napjainkban mind nagyobb társadalmi érdeklődés kíséri az etnikai jellegü kérdéseket és a hozzájuk kapcsolódó lokális folyamatokat (BALIZS D. 2015). Mindemellett a tudományos intézmények is egyre fokozottabb figyelmet fordítanak a társadalmi diverzitás témakörének a kutatására, ahol kiemelten foglalkoznak a különböző etnikumokkal és kultúrákkal (KovÁcs Z. 2017), hiszen a geográfusok közül bárki, aki meg akarja érteni a világ kulturális sokszínüségét nem tekinthet el a nyelvek vizsgálatától (HAGGETT, P. 2006)

\section{Az adatgyưjités és az elemzés során alkalmazott módszerek}

A tanítási nyelvnek kultúrahordozó és -alakító tulajdonsága, a személyekre és a közösségekre gyakorolt hatása különböző tudományterületek érdeklődését felkeltette (VÁMOS Á. 2017). A szórványhelyzettel, a kisebbségekkel, a kisebbségek oktatásával és identitásával foglalkozó kutatások általában interdiszciplináris jellegű megközelítést igényelnek, hiszen e témaköröknek földrajzi, történelmi, demográfiai, néprajzi, kulturális, politikai, jogi, stb. vetülete van. Horváth meglátása szerint az etnicitás, és az interetnikus viszonyok tanulmányozása szükségszerüen is multidiszciplináris megközelítést feltételez (HORVÁTH I. 2006).

A dolgozat témájára és céljára való tekintettel kutatási kérdéseimet interdiszciplináris megközelítésben dolgoztam fel, így a földrajztudományon belül készített releváns munkákon túl, az egyes fejezetek elkészítése során „átlépve a geográfia határait”, nyelvtudományi, neveléstudományi, politikatudományi, közgazdaságtudományi, történelmi, szociológiai kutatások eredményeit és munkáit is felhasználtam. Itt jegyezhető meg, hogy a földrajztudomány igen alkalmas az interdiszciplinaritásra és az összetett tudományos kérdések megközelítésére, valamint további előnye, hogy egyszerre merít a társadalomtudományok és a természettudományok tudáskészletéböl és módszertanából (MÉSZÁROS R. 2014; KovÁCS Z. 2017). Mindemellett az elmúlt évek változásainak köszönhetően, a hazai társadalomföldrajzban egyre nagyobb teret hódítanak más társadalomtudományok eredményei és elméleti megközelítései is (BOROS L. 2008). 
Jelen kutatási téma tehát interdiszciplináris, amely szorosan kapcsolódik a szociológiához és a neveléstudományokhoz is. Az interdiszciplináris témák egyik nagy előnye, hogy a különböző tudományágakhoz tartozó kutatók hasznosíthatják egymás módszereit, megközelítéseit és eredményeit. Jelen bekezdésben Kozma Tamás tanulmányára hivatkozva ismertetem, hogy az egyes tudományterületek képviselöi hogyan közelítik meg a kisebbségi oktatás témakörét. Hiszen a különböző diszciplínák képviselői eltérő tudományos konvenciókat képviselnek, ezért más-más nézőpontból közelítenek a témákhoz (KOZMA T. 2003). Kozma Tamás vélekedése szerint a kisebbségi oktatással foglalkozó pszichológusok többnyire az egyén és a közösség viszonyán keresztül az identitás problémakörét vizsgálják, amelyben az egyéni és a csoportidentitások alakulnak ki (KozMA T. 2003). A történészek és a politológusok főként a kisebbségi oktatás során fennálló „legitimitással és érdekérvényesítéssel" foglalkoznak, úgymint az érdekképviselet, a nyelvhasználat és a közösséghez füződő jogok. A kulturális antropológusok a kisebbségeket kultúrájuk alapján definiálják, véleményük szerint a „kisebbségi sajátosságok kulturális eltérésként írhatók le a többségi kultúrától", és munkáikban a kisebbségek alulról jövő kezdeményezéseire hívják fel a figyelmet. A társadalmi struktúrakutatók a kisebbségekhez kapcsolódó oktatási kérdéseket a társadalmi egyenlőtlenségi probléma szemszögéből kutatják. Ezekben a kutatásokban többnyire a kisebbségek, mint deprivált társadalmi csoportok jelennek meg, ahol a kisebbséghez tartozás a társadalmi struktúrában elfoglalt sajátos helyként értelmezhetö, és ebből kifolyólag a kisebbségi oktatáspolitikának a célja az egyenlőtlenségek kiküszöbölése. Egyik fő kérdésük, hogy azok a különbségek, amelyek a kisebbségi létből, mint külső meghatározottságból fakadnak, milyen iskolai stratégiákkal csökkenthetők (KozMA T. 2003).

$\mathrm{Az}$ empirikus kutatás alatt föként kvalitatív (mélyinterjúkra épülő) módszert alkalmaztam, amely módszernek köszönhetően jobban kirajzolódik a megkérdezett személyek véleményének alakulása. Interjút készítettem a szórványban élő magyar nemzetiségü, illetve vegyes házasságokból származó diákokkal, szüleikkel és a pedagógusokkal is. A kutatási helyszín Nagykikinda (Kikinda), Újvidék (Novi Sad) és Zombor (Sombor) községközpontok voltak, amely településeken a felmérés időpontjában létezett mind magyar, mind pedig szerb tannyelvü általános iskolai oktatás, tehát a diákoknak és szüleiknek volt választási lehetősége az általános iskola tannyelvének megválasztására. Az empirikus kutatás folyamata a felsorolt föbb lépések szerint történt: mintaterületek kiválasztása, interjúalanyok felkutatása, interjúkészítés- adatgyüjtés, adatok feldolgozása és elemzése.

A tanulmányban szereplő adatok a Szerbiai Statisztikai Hivatal és a Tartományi Oktatási Titkárság adatbázisából származnak. Mindemellett a szekunder adatgyüjtés során igyekeztem mindazon rendelkezésre álló szakirodalmat feldolgozni, melyek releváns adatokkal szolgálhatnak a témában, valamint szakirodalom feldolgozása során felhasználtam a Magyar Tudományos Müvek Tárának (MTMT) elektronikusan elérhető adatbázisát is. A szakirodalom feldolgozásán túl, nagy hangsúlyt fektettem a Magyar Nemzeti Tanács² által

2 A 2002-es évtől létező Nemzeti Tanácsok kezdetben kis hatáskörrel rendelkeztek. Elektori rendszerben választották meg őket, így valójában 2010-től váltak fontossá az új törvény elfogadása után. A kisebbségek 2010-ben és 2014-ben választhattak maguknak nemzeti tanácsot (NT), oly módon, hogy a választóknak fel kellett iratkozniuk egy külön választói listára. A választásokon listák indulhattak (pártok nem, de támogathatták a listákat). Attól függ a Nemzeti Tanács képviselőinek száma, hogy a népszámlálási adatok alapján mekkora létszámú az adott kisebbség (így 15-től 35 tagja lehet egy Nemzeti Tanácsnak). A legkisebb közösségek esetében még most is lehetséges az ún. elektori választás, amikor a jelöltet szervezet vagy egyesület nevesíti. A nemzeti 
kidolgozott stratégiai és egyéb fejlesztési dokumentumok és akciótervek elemzésére is, amely főként a szórványban élők helyzetével foglalkozik. Ezen dokumentumokat a Magyar Nemzeti Tanács honlapjáról értem el. Az értekezés szempontjából releváns fejlesztési dokumentumok és akciótervek tanulmányozása során a Tanács által kidolgozott legújabb dokumentumokat elemeztem (Népesedési akcióterv 2013-2017, Oktatásfejlesztési Stratégia 2010-2016, Vajdasági magyar kulturális stratégia 2012-2018). Felhasználtam továbbá a Vajdasági Magyar Pedagógusok Egyesülete, és az Észak-Bácskai Magyar Pedagógusok Egyesülete által kiadott dokumentumokat és zárónyilatkozatokat. Mindamellett a kutatás szempontjából további hasznos forrásokkal (pl. jogszabályok, statisztikai jelentések) bővítettem munkám.

Kutatási ösztöndíjaknak ${ }^{3}$ pályázatoknak ${ }^{4}$ köszönhetően a 2013-as és 2014-es évek között interjús kutatásokat végeztem három szórványtelepülésnek számító községközpontban, melynek során az általános iskolák tanárait, diákjait, valamint a diákok szüleit kérdeztem meg a tannyelv-választás hátteréről. A kutatási helyszínek közül Nagykikindán 13 interjút, Újvidéken 14 interjút, Zomborban 15 interjút készítettem. A három mintaterületen összesen, tehát 42 interjú készült. A kutatás során strukturált (diákok), és félig strukturált interjúk készültek (szülők, pedagógusok), a pedagógusokkal készített interjúk esetében kitértem a saját iskolai életútjukra, továbbá saját gyermekeik iskoláztatására is, ami további hasznos eredményeket hozott. A pedagógusokkal folytatott interjúk egy része életút interjú kategóriába is sorolható. Ennek előnye, hogy ezen személyek (tanárok) a saját szavaikkal mesélték el életüket, és elmondhatták problémáikat (TIMÁR J. 2001).

Az empirikus kutatás alatt alkalmazott módszertan egy korábbi kutatás ${ }^{5}$ során került kidolgozásra, amely az iskolaválasztás és asszimiláció tárgykörében 2013-2014-ben készült a Vajdaságban, és más Kárpát-medencei régiókban. A kutatás vezetője Bodó Barna volt, a felmérést az MTA Domus 2012.évi pályázata támogatta: Többségi nyelvü iskolaválasztás címmel. Ezen kutatás keretében kidolgozott tematikát, módszertant, mintaválasztási eljárást és interjúkérdéseket alkalmaztam a nagykikindai, az újvidéki és a zombori mintaterületek során is. A Nagykikindán végzett felmérést ${ }^{6}$ a fentiekben említett kutatás keretén belül végeztem el, a zombori és az újvidéki mintaterületen történt kutatást ${ }^{7}$ pedig a „TÁMOP-4.2.4.A/2-11/12012-0001 azonosító számú Nemzeti Kiválóság Program” támogatta.

A kutatás során az iskolaválasztás és az oktatás nyelvének megválasztásán túl, számos egyéb témáról szó esett, úgy mint a nemzeti identitás, az elvándorlás, a külföldi munkavállalás, a pedagógusok helyzete, a diákok kompetenciája, a mindennapi nyelvhasználat, a helyi lokális és gazdasági problémák, a kisebbségi léthelyzet és az interetnikus kapcsolatok.

A mintaterületek (községközpontok) kiválasztásakor két fontos tényező játszott szerepet. Az első szempont szerint mindhárom településen elérhetőnek kellett lennie egyaránt

tanácsok jogköre alapvetően négy területre vonatkozik: az oktatásra, a tájékoztatásra, a kultúrára és a nyelvhasználatra (Szerbhorváth Gy. 2015).

${ }^{3}$ MTA Domus Szülöföldi Ösztöndíj 2013

4 TÁMOP-4.2.4.A/2-11/1-2012-0001 azonosító számú Nemzeti Kiválóság Program - Hazai hallgatói, illetve kutatói személyi támogatást biztosító rendszer kidolgozása és müködtetése konvergencia program. A projekt az Európai Unió támogatásával, az Európai Szociális Alap társfinanszírozásával valósult meg

5 Többségi nyelvű iskolaválasztás címü kutatás, amelyet az MTA Domus 2012.évi pályázata támogatott

${ }^{6}$ MTA Domus Szülöföldi Ösztöndíj 2013

7 TÁMOP-4.2.4.A/2-11/1-2012-0001 azonosító számú Nemzeti Kiválóság Program - Hazai hallgatói, illetve kutatói személyi támogatást biztosító rendszer kidolgozása és müködtetése konvergencia program. A projekt az Európai Unió támogatásával, az Európai Szociális Alap társfinanszírozásával valósult meg 
a szerb és a magyar nyelvü oktatásnak, a második kritériumot pedig a település földrajzi elhelyezkedése (tájegységi elhelyezkedése) jelentette. Mivel minden területi szemléletü kutatásban alapvető dilemmát jelent a releváns területi egységek lehatárolása (FORRAY R. K.KozMA T. 1992.), ezért a mintaterületek kiválasztásakor arra törekedtem, hogy a települések lefedjék a tartomány keleti, nyugati és déli részét. Így esett a választás Nagykikindára (Kikinda), amely a Vajdaság keleti részén, Bánát tájegységben található, továbbá Újvidékre (Novi Sad), amely a Vajdaság déli részében, a Dél-bácskai körzetben helyezkedik el, valamint Zombor (Sombor) községre, amely a Vajdaság nyugati részén a Nyugat-bácskai körzetben terül el (2. ábra). A kutatás szempontjából Gábrity Molnár Irén a már fentiekben említett szórvány meghatározását vettem figyelembe. Mindemellett a mintaterületek kiválasztásában az a további szempont is közrejátszott, miszerint a Magyar Nemzeti Tanács 2011-ben készült jelentéséből kitünik, hogy ezekben a községközpontokban egyre nehezebbé válik a magyar nyelvü tagozatok megnyitása. ${ }^{8}$

\section{2. ábra: Magyar nemzetiségúek aránya községenként Vajdaság területén a 2011-es népszámlálás adatai} alapján

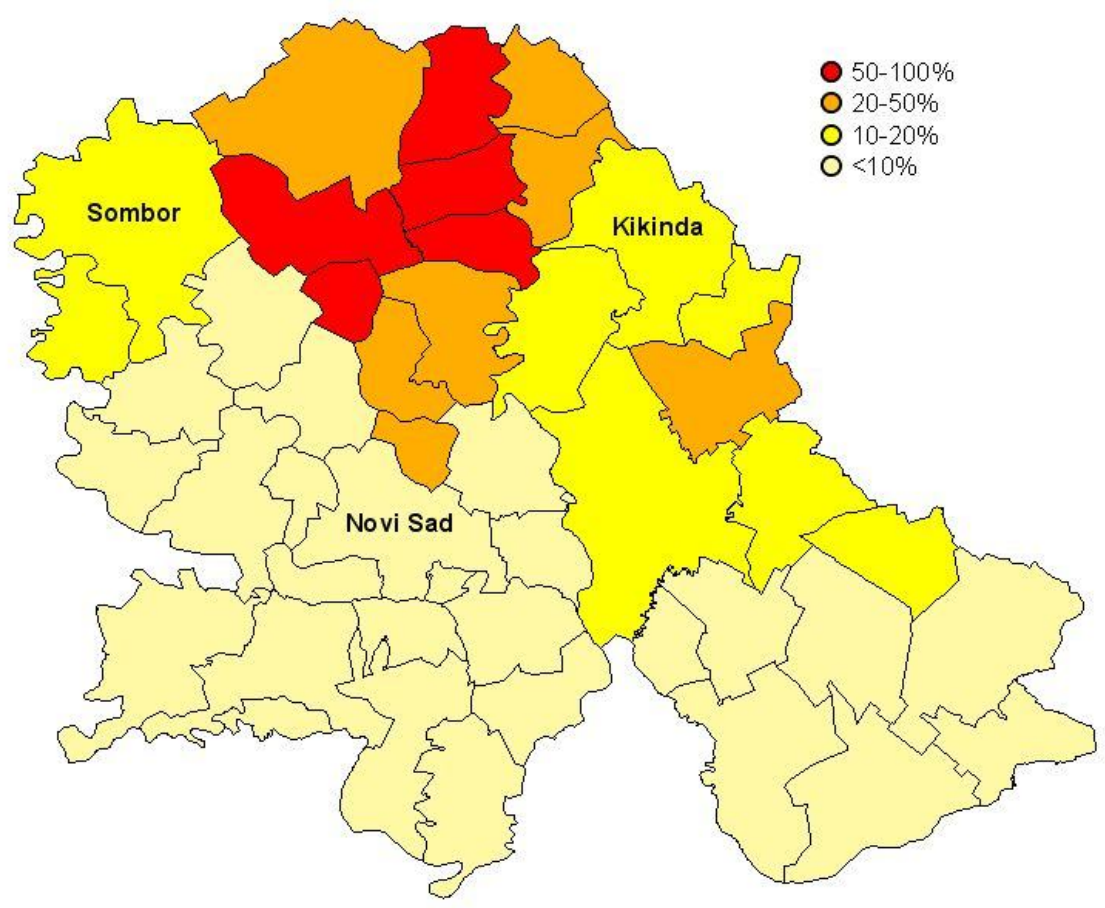

Forrás: saját szerkesztés

A vizsgált mintaterületek lakosságszámát tekintve Újvidék a legnagyobb település, majd Zombor és Nagykikinda. A vizsgált területi egységek községközpontok voltak, tehát urbanizált népesség körében készült a felmérés, amelyhez hozzá kell tenni, hogy a városi környezet elösegíti a domináns többségi nyelvhez való alkalmazkodást, tehát a nagyobb városokban a nyelvváltás sokkal gyakoribb jelenség, mint a falusi környezetben, ahol a

\footnotetext{
${ }^{8}$ MNT 2011: Oktatásfejlesztési stratégia megvalósítása egy év távlatából
} 
kisebbségi nyelvet beszélők koncentráltan élnek ${ }^{9}$ (LAPONCE, J. 1987; PUSKÁs T. 2000). Több kutatás eredménye is rámutatott arra, hogy az urbanizáció elősegíti a nyelvi asszimilációt, mert a nyelvek közti kontaktus a legtöbb esetben a domináns nyelv oldalára billenti a mérleg nyelvét, és így a nagyvárosokban a nyelvváltás sokkal gyakoribb jelenség, mint a falvakban, ahol a kisebbségi nyelvet beszélők koncentráltan élnek, és így nyelvük dominanciája megörizhető (PUSKÁs T. 2000).

Az alkalmazott módszertan szerint a vizsgálatba olyan szerb tannyelvü osztályokban tanuló hatodik és hetedik osztályos tanulókat kellett bevonni, akik magyar nemzetiségűek vagy vegyes nemzetiségü családból származnak. Mindemellett interjú készült a diákok szüleivel és a pedagógusokkal is. A pedagógusok nemzetiségét tekintve 3 fó szerb nemzetiségü volt, 3 fö vegyes (szerb-magyar) nemzetiségünek vallotta magát, a többiek magyar nemzetiségüek voltak. A pedagógusokkal készített interjúk esetében kitértem a saját iskolai életútjukra, továbbá saját gyermekeik iskoláztatására is, ami további hasznos eredményeket hozott. Az eredeti elképzeléstől eltérően, a későbbiekben (mindhárom mintaterületen: Nagykikinda, Újvidék, Zombor) a célcsoportot kibővítettem, és nemcsak hatodik és hetedik osztályos tanulók kerültek be az interjú készítés folyamatába, hanem ötödikes és nyolcadikos tanulók is, tehát a kutatásban felső tagozatos diákok vettek részt. A diákok célcsoportját tekintve, azért volt indokolt a kibővítés, mert több esetben a hatodik és hetedik osztályban járó diákok és szüleik nem engedélyezték az interjúkészítést, így további interjúalanyok megkeresése volt szükséges. Mindemellett, a zombori mintaterületen a lekérdezésben olyan pedagógusok is részt vettek, akik az általános iskola mellett középiskolákban is tanítottak.

$\mathrm{Az}$ alanyok megkeresése személyes kapcsolati hálókon keresztül indult el, majd a mintavétel során „hólabda módszert” alkalmaztam, amelynek lényege, hogy a kutató adatokat gyüjt a megcélzott populációba tartozó néhány személytől, akiket meg tud találni, majd megkéri őket, hogy adják meg más általuk ismert, a populációba tartozó személyek elérhetőségét (BABBIE, E. 2008). Először tanárokkal, majd a tanárokon keresztül a diákokkal, és rajtuk keresztül szüleikkel kerültem kapcsolatban, de természetesen több esetben közvetlenül (személyes kapcsolati hálón keresztül) tudtam elérni a szülöket.

Az interjú során feltett kérdéseket öt nagyobb csoportra lehet bontani. A kérdések a családi háttérre, az iskolai életútra, az iskola jellemzésére, a társas kapcsolatokra és a diákok jövőbeli terveire vonatkoztak. Az interjúk lefolytatása a szülőkkel átlagosan háromnegyed órát, a pedagógusokkal egy - másfél órát vett igénybe, míg a diákokkal való interjúkészítés folyamata átlagosan húsz perc volt. Az interjúalanyok nyelvtudásához és kéréséhez igazodva magyar és szerb nyelven történt a lekérdezés. A kutatás főleg a pedagógusok és a szülök véleményét és meglátásait tükrözik, ennek oka, hogy az interjúkészítéskor tőlük kaptam a legtöbb információt.

Az interjút adó egyének felkutatása során arra törekedtem, hogy főleg közvetlen kapcsolati hálón keresztül keressem fel őket, ezáltal azt feltételeztem, hogy ezen személyekkel egy bizalmasabb beszélgetést tudok majd kialakítani, ahol bátran beszélhetnek döntésükröl, tehát a beszélgetést ne befolyásolja pártpolitika, vagy esetleg egy intézmény programja.

\footnotetext{
${ }^{9}$ Laponce munkájában kifejti, hogy a kisebbségi nyelvek túlélésének alapvető feltétele, hogy az etnolingvisztikai közösség tagjai valódi közösségekben, területileg koncentráltan éljenek (LAPONCE, J. 1987).
} 
Nagykikindán általában jellemző volt, hogy inkább az apa volt magyar nemzetiségű, Újvidéken és Zomborban az anya és az apa nemzetiségét tekintve vegyesen kerültek a mintába, illetve Újvidéken egy szülőpár volt, akik mindketten magyar származásúak voltak, viszont a szülők maguk is vegyes nemzetiségü felmenőkkel rendelkeztek.

Az interjúkészítés során a megkérdezett személyek sokszor eltértek a kutatás tárgyától, viszont az általuk elmondott plusz információk nagyban segítették a településen élők helyzetének, vagy akár egy család döntésének megértését. Ahhoz, hogy a szülökkel, a diákokkal és a pedagógusokkal készített interjúkat közel azonos módon tudjam elemezni, ezért azonos kutatási csomópontokat határoztam meg, így alakult ki a három településről gyüjtött információk közel egységes váza. Közös csomópontnak tekintettem: a családi hátteret (nyelvhasználatot), a gyermekek létszámfogyását, a saját véleményüket a tannyelvválasztásról, az iskola jellemzését és marketing tevékenységét, és a diákok jövőképet.

\subsection{Az empirikus kutatás sajátosságai és nehézségei}

A kutatás során több nehézség is felmerült, amelyet jelen fejezetben részletesen kifejtek. A legfőbb nehézségeket a következők jelentették: azon családok felkutatása, akiknek tagja vagy tagjai a magyar gyökerekhez köthetőek, de gyermekeiket szerb nyelven iskoláztatják, illetve további gondot jelentett, hogy a szülök közül többen elutasították az interjúkészítést. E fejezet keretein belül továbbá részletezem, hogy a kutatás szempontjából mely személyeket tekintettem magyar nemzetiségünek.

Az első nehézséget az jelentette, hogy fel kellett keresni azokat a szülöket, családokat, akik a magyar közösséghez tartozóknak vallják magukat, de gyermeküket szerb nyelven taníttatják. Mivel nem áll rendelkezésre olyan nyilvános statisztikai adatbázis, amelyből kiválaszthatóak lennének a magyar, illetve többségi tannyelvü iskolát választó szülök, ezért személyes kapcsolati hálón keresztül indult el a mintavételi eljárás, majd a fent említett hólabda módszert alkalmazva jutottam el az interjúalanyokig.

Barth munkájában leírja, hogy az etnikai hovatartozás identitás kérdése, ezért besoroláson vagy önbesoroláson kell alapulnia, amelyhez kutatásom is igazodott (BARTH, F. 1996). Jelen kutatás szempontjából tehát magyar nemzetiségünek tekintettem az önmagukat magyar kötődésüeknek vallókat, viszont itt hozzáfüzném, hogy több interjúalany bizonytalan volt nemzetiségében, egyfajta köztes vagy kettős identitás volt érzékelhető. Az, hogy kit tekintünk magyar nemzetiségünek föleg egy szórvány területen, ez akár igen bonyolult kérdésé is válhat, és ehhez kapcsolódóan Biczó (2005) munkásságára hivatkozom. A tanulmányában leírtak szerint 2003-ban egy bukovinai településen Rádócon (RadautzRadăuți) a Magyarországról érkező vendéget a helyi magyar kisebbségi élet szervezői megismertették a közösséghez kötődő személyekkel. A bemutatkozás után a látogató kérdésére, hogy beszélnek-e magyarul, egy 14 éves kislány a következőképpen válaszolt: „Nu, dar eu sînt ungur”-,Nem, de magyar vagyok” (BICzó G. 2005, p.34.). Ehhez kapcsolódóan a kutató a tanulmányában a következő kérdéseket vetette fel: „Vajon a rádóci kislány tagja-e még a városban található kisszámú magyar etnikai szórványnak, vagy sem? Románul megfogalmazott etnikai identitása, vagy esetleg befejezett nyelvi asszimilációja alapján sorolható-e a szórványba, illetve az asszimilált magyarok igen homályos társadalmi csoportjába? Kérdés, hogy a rádóci szórvány még magyarul aktívan tudó tagjai a kislány vallomásszerü megnyilatkozását legitimnek ítélik, vagy a szórványidentitás bevett feltételeinek tekintett nyelvtudás hiányának okán kirekesztik? Mit kezd a tudományos érdeklődés ezzel a stílussal?" (BıCzóK G. 2005, p.34.). Az idézettel érzékeltetni szerettem 
volna, hogy a szórványban föleg a vegyes nemzetiségü családoknál a nemzetiség kérdésének meghatározása nem minden esetben egyértelmü.

Mindhárom mintaterületen főleg vegyes házasságban élő szülőkkel sikerült interjút készíteni, ahol a szülők maguk is, több estben, vegyes házasságból származtak. Ezekben a családokban a megkérdezett diákok többségében jobban beszéltek szerb nyelven, mint magyarul, tehát a nyelvhasználat a szerb nyelv felé tolódott el. Hasonló helyzet alakult ki, mint amit Árendás Zsuzsanna Délnyugat-Szlovákiában végzett kutatása is feltárt, miszerint a magyar nyelvi hátterü vagy vegyes házasságból származó gyermekek szlovák iskolába íratásakor általános tényezőként jelentkezett, hogy a gyermek otthoni nyelvhasználata igazodott az iskolaihoz, azaz a család korábbi magyar vagy kettős nyelvhasználata az évek során eltolódott a szlovák nyelv felé, abban viszont különbségek mutatkoztak, hogy ez az eltolódás végleges-e, vagy átmeneti jelenségről van szó (ÁRENDÁs Zs. 2012).

Mindhárom mintaterületen nehézséget jelentett, hogy különböző megfontolásból a szülők közül többen elhárították az együttmüködést, kevesen vállalták az interjút, többszöri megkeresésre is nemleges választ kaptam, emiatt bővítettem a célcsoportom tagjait is (felső tagozatos diákok). Úgy vélem viszont, hogy azokkal a szülőkkel és pedagógusokkal, akik részt vettek az interjú készítés folyamatában a beszélgetések során sikerült pozitív légkört kialakítani, sőt az interjú végén több esetben is szó esett olyan dolgokról, ami konkrétan nem kapcsolódik a kutatás tárgyához, viszont valósabb képet adott a helyi állapotokról. Ezen felül a kutatásba bevont mintaterületeken túl, az adott községhez tartozó további településekről is információt kaptam. Példának okáért a zombori kutatásom során felmerült a községhez tartozó, Doroszló (Doroslovo) és Szilágyi (Svilojevo) magyar közösségének létszámfogyása, illetve az Újvidéken végzett kutatás során több esetben szó esett Temerin (Temerin), és Óbecse (Bečej) községek helyi társadalmának állapota. A szóban forgó települések azért kerültek említésre, mert a pedagógusoknak és/vagy a szülőknek rokoni, baráti, vagy egyéb kötődésük volt az adott településhez, és ezáltal további hasznos információkkal bővült a kutatási anyag.

\section{Vajdaság Autonóm Tartomány bemutatása}

Az oktatással, nyelvválasztással kapcsolatos mikro-társadalmi jellemzők kutatásakor elengedhetetlen a tágabb földrajzi, etnikai, demográfiai, közigazgatási és gazdasági kapcsolatok és struktúrák jellemzőinek az ismertetése. E fejezet fontos a kutatási téma szempontjából, hiszen a vizsgált mintaterületek (községközpontok) társadalmi folyamatai csak egy tágabb, makroszintü kontextusban értelmezhetőek és vizsgálhatóak. Mindemellett ezen jellemzők is formálják az adott közösséget, és kihatással vannak fejlődésére és vitalitására. Egy közösséget érintő téma vizsgálatakor számba kell venni azon külső tényezőket, amelyek befolyásolják a helyi kisebbségi közösség mindennapjait.

\section{1. Általános földrajzi jellemzők}

Vajdaság Autonóm Tartomány a Szerb Köztársaság északi része, székhelye Újvidék (Novi Sad), területe $21.506 \mathrm{~km}^{2}$. Természetföldrajzi szempontból a tartományt három nagy folyó, a Duna, a Tisza és a Száva három tájegységre osztja: Bácskára, Bánátra és a Szerémségre. Az országon belül Vajdaság viszonylag fejlett térségnek számít. A síkságból csak a szerémségi és a bánáti tájegységben emelkednek ki szigethegységek: ezek a Fruška 
Gora (Tarcal-hegység) és a Verseci-hegység (ProbÁld F. 2007, BElankA Cs. 2007). Vajdaság lakossága az utolsó népszámlálás alkalmával (2011-ben) 1931889 fö volt. ${ }^{10} \mathrm{~A}$ 2002-es és a 2011-es népszámlálási időszak között a tartomány lakossága hozzávetőlegesen 100000 fövel csökkent (Kocsis K. et al. 2015).

Vajdaság Autonóm Tartomány legmagasabb jogi rendelkezése a statútum, amelynek az alkotmánnyal összhangban kell állnia. A dolgozat témájának szempontjából fontos kiemelni, hogy az említett statútum értelmében a kisebbségek tagjai számarányosan képviseltethetik magukat a vajdasági parlamentben. A tartomány szervei a képviselőház, a végrehajtó tanács és a közigazgatási szervek.

Közigazgatási szempontból jelenleg Vajdaság 7 körzetre (okrug) és 45 községre (opština) tagolódik. A hét körzet (okrug) a következő: Dél-bácskai körzet, Dél-bánsági körzet, Észak-bácskai körzet, ${ }^{11}$ Észak-bánsági körzet, Közép-bánsági körzet, Nyugat-bácskai körzet és a Szerémségi körzet. A körzetek elvileg olyan területi egységek, amelyek a központi és a lokális szint között helyezkednek el, viszont nem rendelkeznek önálló feladatkörrel, kizárólag olyan tevékenységeket látnak el, amelyeket a köztársasági minisztériumok engedélyeznek (NAGY I. 2015). Ezek a körzetek nem minden esetben követik a tájegységek természetes földrajzi határait. Közigazgatásilag a körzetek tovább „bonthatóak” községekre (opština), amelyek sajátos területi igazgatási-önkormányzati egységek (3. ábra), ugyanis a község több települést összefogó, legalacsonyabb szintü közigazgatási egységet jelent, ami jellemzően egy nagyobb települést (várost) és közvetlen vonzáskörzetét foglalja magába (KUGLER J. 2007; NAGY I. 2015).

A község székhelye - amiröl általában az egész községet is elnevezik - a községközpont (KUGLER J. 2007). Egymáshoz viszonyítva a községek terület- és népességszám szerint igen eltérőek lehetnek, viszont közös tulajdonságuk, hogy városias és falusias tereket egyaránt magukba foglalnak, és „tükrözik a térségre jellemzö településhálózati sajátságokat" (KUGLER J. 2007). A fenti községre vonatkozó definíció értelmében Vajdaság területén összesen 45 község létezik, amely 467 települést ölel fel, tehát átlagosan 1 községre körülbelül 10 település jut (KoCSIS K. et al. 2006).

Vajdaság városhálózatának élén, mind funkcionális, mind térszerkezeti szempontból Újvidék (Novi Sad) áll, amelynek vonzáskörzete igen kiterjedt (BELUSZKY P. - KovÁCS Z. 2012). A városnak egyaránt kiemelkedő szerepe van politikai, demográfiai, kulturális, gazdasági és oktatási szempontból (KUGLER J. 2007). A tartomány további fontosabb, központi funkcióit is ellátó települései: Szabadka (Subotica), Zombor (Sombor), Nagybecskerek (Zrenjanin), Pancsova (Pančevo), és Szávaszentdemeter (Sremska Mitrovica). A tartomány népességének a fele 2 ezer és 20 ezer fö közötti településeken él (BELUSZKY P. KovÁcs Z. 2012).

Kovács tanulmányában leírtak szerint Vajdaságban a községek számos komplex településkörnyezeti és társadalmi-gazdasági problémakörrel küzdenek, amelyek szorosan összefüggenek egymással (KovÁcs A. D. 2015). Ezen problémák között megtalálhatóak a termelöi és vállalkozói szektor bizonytalanságai, a környezetvédelmi kérdések megoldatlansága, az infrastrukturális felzárkózás késedelme, a város-falu kapcsolatok szétesése, valamint a rurális leértékelödés általános tünetei is; az elöregedés, az elvándorlás, a

\footnotetext{
${ }^{10}$ Popis stanovništva, 2011

${ }^{11}$ Az Észak-bácskai körzetben él a vajdasági magyarság közel harmada
} 
kirekesztődés és a fokozódó szociális feszültségek (szegénység, bünözés, szuperszegregáció) (KovÁCS A. D. 2015).

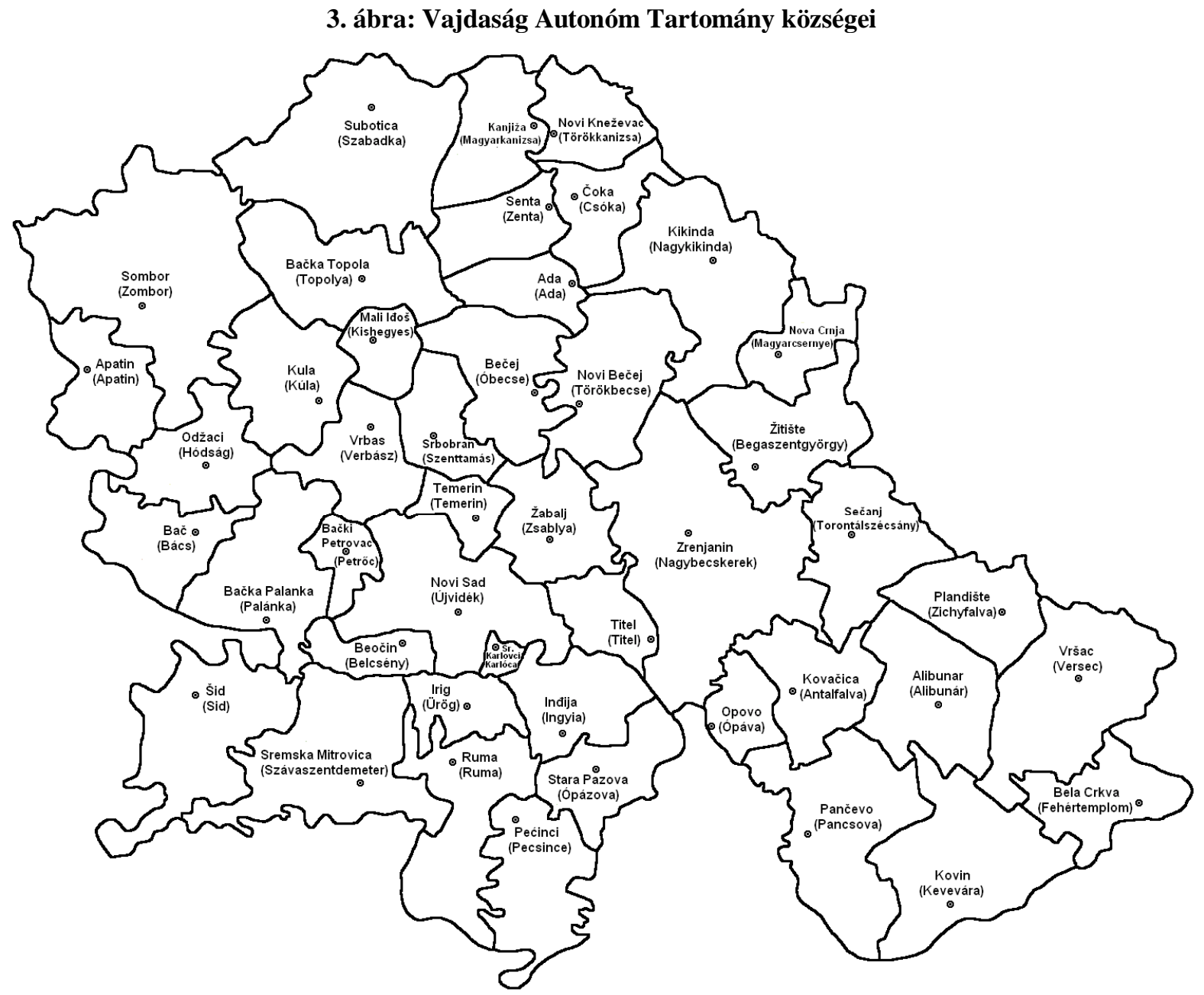

Szerkesztette: Trombitás Tímea, 2016

\subsection{Gazdasági jellemzők}

Az egykori Jugoszlávia szétesése, a regionális háborúk, valamint a gazdasági embargó, mély és elhúzódó gazdasági hanyatlást eredményezetek Szerbiában (HUSZKA B. BAKÓ T. 2007). Ezek hatására számtalan társadalmi, politikai és gazdasági változás következett be, melyek hatással voltak az országban élő egyénekre, családokra, közösségekre, mindemellett ezen társadalmi változások hatással voltak az interetnikus viszonyokra és kapcsolatrendszerekre is, emiatt fontos kitérni a dolgozat keretein belül a gazdasági környezet fontosabb jellemzöire is.

A hanyatlást és a háborús időszakot követően gazdasági szerkezetváltás csak a 2001es évtől kezdődött meg, amikor is a parlament elfogadta az új privatizációs törvényt. Ezt követően az országban egy nagyon lassú növekedési trend volt megfigyelhető, majd 2004-ben a gazdaság fenntartható növekedési pályára került. Mindenütt beindult a nemzeti jövedelem bővülése, ami részben a privatizációnak volt köszönhető (HUSZKA B.- BAKÓ T. 2007). 
Vajdaságban elsősorban a mezőgazdaság, ${ }^{12}$ az élelmiszer-, a fém- és vegyipar, továbbá az építő- és a textilipar mondható jelentősnek (GÁBRITY MOLNÁR I. 2006). Miután az ország gazdaságában a korábban uralkodó nagyvállalati struktúra gyakorlatilag összeomlott, a kis- és középvállalati gazdasági szerkezet épült ki, melynek gazdasági súlya és szerepe mára jelentőssé vált. ${ }^{13}$ Jelenleg Vajdaság tevékenységét a mikro és kisvállalkozások magas aránya jellemzi, ezek a vállalkozások a munkahelyek egyharmadát képezik. ${ }^{14}$

A munkanélküliség súlyos probléma egész Szerbiában, így Vajdaságban is, amely egyaránt sújtja a női és a férfi munkavállalókat, a pályakezdőket és azokat, akik korábban már munkaviszonyban álltak (SZLÁVITY Á. 2008). Ezért a fiatal szakképzett munkanélküliek már néhány évtizede tömegesen külföldre távoznak az országból. Az elvándorlás föleg a fiatal, tanult és szakképzett csoportokat sújtotta/sújtja (NAGY I. 2006). Az elvándorlásra, a munkanélküliségen és a háborús válságon kívül fontos motivációs tényezőként hatott a bizonytalanság, a szociális-anyagi helyzettel való elégedetlenség, valamint a reformok lassúsága. ${ }^{15}$ A magasan kvalifikált szakemberek elvándorlása további problémákat generál a térségben, úgymint a lassuló gazdasági fejlődés, munkatermelékenység-csökkenés és versenyképesség vesztés (KINCSES Á. 2012). Mindemellett általánosságban az elvándorlásnak további hosszabb távon is jelentkező negatív hatásai lehetnek, úgymint az ellátórendszerek fenntarthatóságának veszélybe kerülése, illetve a költségvetés egyenlegének felborulása (LADOS G. et al. 2015).

\subsection{Etnikai megoszlás}

Etnikai és kulturális kérdésekben Vajdaság területe mint határ menti régió érdekes kutatási területként szolgálhat, hiszen társadalmi és kulturális vonatkozásaiban a régió egyedülálló multikulturális és többnemzetiségü terület (DJURDJEV, S. B. et al. 2003; KOVAČEVIĆ, T. et al. 2010; ĐERČAN, B. et al. 2017). Vajdaság területe a történelmi eseményeknek, az évszázadok alatt végbement migrációnak, és az államalakulatok átszerveződésének következtében vált multietnikus és multikulturális térséggé (TÁTRAI P. et al. 2014). A történelem folyamán és napjainkban is, különböző származású, anyanyelvü és vallású közösségek tagjai élnek itt, jelenleg is több mint húsz etnikai csoport él e területen (HAJDÚ Z. - SZÜGYI É. 2015; GÁBRITY MOLNÁR I. 2005b). Az államalkotó nemzet (szerb) tagjain kívül, jelentős számban élnek itt magyar, szlovák, horvát, montenegrói, román, ruszin, bunyevác és roma nemzetiségüek is (1. táblázat). Vajdaság területén hat nyelv van hivatalos használatban, amely tükrözi a vidék sokszínü etnikai és nyelvi összetételét (GÁBRITY MOLNÁR I. 2008a, HUSZKA B. 2008). A szerb nyelv mellet ezek a következők: magyar, szlovák, román, ruszin és horvát.

Az elmúlt évtizedek politikai és gazdasági történései átalakították a tartomány etnikai, demográfiai és társadalmi szerkezetét (KICOŠEV - KoCSIS 1998; KOVAČEVIĆ, T. - KICOŠEV, S. 2007). A kilencvenes években lezajlott háborúk ideje alatt csökkent a természetes népszaporulat, és növekedett a külföldre irányuló emigráció, mindamellett a jugoszláv utódállamokból jelentős számú szerb nemzetiségü menekült lakosság érkezett Vajdaság

\footnotetext{
${ }^{12}$ A mezőgazdaságban foglalkoztatottak aránya az országos átlag több mint kétszerese

13 TÁMOP-1.3.1-07/1.-2008-0002 „Az Állami Foglalkoztatási Szolgálat fejlesztése az integrált munkaügyi és szociális rendszer részeként" c. kiemelt projekt, 3.6 alprojekt

14 TÁMOP-1.3.1-07/1.-2008-0002 „Az Állami Foglalkoztatási Szolgálat fejlesztése az integrált munkaügyi és szociális rendszer részeként" c. kiemelt projekt, 3.6 alprojekt

${ }^{15}$ Hídvégi Mikó Imre Kutatóintézet Alapítvány tanulmánya alapján
} 
területére (Golubović, P. - Marković Krstić, S. 2006; GÁbrity MolnáR I. 2011; TÁtrai P. et al. 2013). A Vajdaságra jellemző demográfiai helyzetkép ellentmondásos, ugyanis jellemző a lakosság elvándorlása és elöregedése, valamint a születések számának csökkenése, viszont a bevándorlási folyamatok (menekült személyek betelepedése) a lakosság növekedését eredményezték (KINCSES Á. 2012). Az elmúlt évtizedben a cigány népességet kivéve, az összes etnikai csoport létszáma csökkent, de a kisebbségek fogyásának mértéke (elöregedésük, asszimilációjuk és magas kivándorlási hajlandóságuk következtében) meghaladja az államalkotó nemzetét (KoCSIS K. et al. 2015).

1. táblázat: Vajdaság Autonóm Tartomány nemzetiségi összetétele, 2011

\begin{tabular}{|c|c|c|}
\hline \multicolumn{3}{|c|}{ Vajdaság nemzetiségi összetétele 2011-ben } \\
\hline Nemzetiség & Fö & $\%$ \\
\hline Szerb & 1289635 & 66,76 \\
\hline Magyar & 251136 & 13,00 \\
\hline Szlovák & 50321 & 2,60 \\
\hline Horvát & 47033 & 2,43 \\
\hline Roma & 42391 & 2,19 \\
\hline Román & 25410 & 1,32 \\
\hline Montenegrói & 22141 & 1,15 \\
\hline Bunyevác & 16469 & $\mathbf{0 , 8 5}$ \\
\hline Rutén & 13928 & 0,72 \\
\hline Jugoszláv & 12176 & $\mathbf{0 , 6 3}$ \\
\hline Macedón & 10392 & 0,54 \\
\hline Ukrán & 4202 & 0,22 \\
\hline Muszlim & 3360 & 0,17 \\
\hline Német & 3272 & $\mathbf{0 , 1 7}$ \\
\hline Albán & 2251 & 0,12 \\
\hline Bolgár & 1489 & 0,08 \\
\hline Szlovén & 1815 & 0,09 \\
\hline Gorán & 1179 & 0,06 \\
\hline Orosz & 1173 & 0,06 \\
\hline Boszniai & 780 & 0,04 \\
\hline Vlah & 170 & 0,01 \\
\hline Nem nyilatkozott & 81018 & 4,19 \\
\hline Regionális kötődés & 28567 & 1,48 \\
\hline Egyéb & 6710 & $\mathbf{0 , 3 5}$ \\
\hline Ismeretlen & 14791 & 0,77 \\
\hline
\end{tabular}

Forrás: Republika Srbija, Republički Zavod za Statistiku (RZS) - Stanovništvo: Nacionalna pripadnost, 2011 (Knjiga 1). 
Penev adati szerint 1991 és 1995 között 157084 fö telepedett le Vajdaság területén, amely személyeknek több mint 94 százaléka az egykori Jugoszlávia valamely tagköztársaságából érkezett. Az utána következő években, 1996-tól 2002-ig pedig további 56111 fó érkezett, és több mint 72 százalékuk szintén a széteső délszláv állam valamely tagköztársaságából települt át (PENEV, G. 2006). A betelepülők nagy száma ellenére negatív a migrációs mérleg, ugyanis a 2011-es adatok szerint mintegy 15 ezer fövel többen költöznek el, mint ahányan betelepülnek Vajdaságba (GÁBRITY MOLNÁR I. 2015). A tartomány esetében, mindenhol csökkent a népességszám, ez alól csak Újvidék képez kivételt. A nagyobb városok községei 5 százalék körüli népességcsökkenést, míg a kisebb községek 1015 százaléknyi csökkenést mutattak (GÁBRITY MOLNÁR I. 2015).

\subsubsection{A vajdasági magyarság demográfiai-és társadalomszerkezeti jellemzői}

Vajdaság lakosságának több mint a fele szerb nemzetiségű, viszont az államalkotó nemzet képviselőit követően a legnépesebb etnikai közösség a magyar kisebbség. A 2011. évi népszámlálási adatok szerint Szerbiában 253899 fő vallotta magát magyar nemzetiségünek, amelyből 251136 fő Vajdaság területén élt. ${ }^{16}$ A tartományban, a magyar nyelvet 241164 fö tartotta anyanyelvének. ${ }^{17}$ A magyar kisebbség részaránya az ország összlakosságához viszonyítva 3,5 százalék, míg a tartomány összlakosságához viszonyítva 13 százalék (KAPITÁNY B. 2013). A 2002-es népszámlálás adataihoz képest az összmagyar lakosság 2011re 39400 fövel csökkent. ${ }^{18}$

Szerbiában a magyar kisebbség által lakott községek többnyire Vajdaság északi részén helyezkednek el, a magyar nemzetiségüek többsége a Magyarországgal határos régiókban és a Tisza-mentén él. ${ }^{19}$ A „leginkább magyarnak” tekinthető települések tömbjét Bácska északkeleti részén, a Tisza jobb partjához tapadó Horgos (Horgoš) - Bácstopolya (Bački Topola) - Bácsföldvár (Bačko Gradište) háromszögben találjuk (Kocsis K. - Kocsis-HodosI E. 1998). Vajdaságon belül Bácska a legnépesebb tájegység, ahol a legtöbb magyar nemzetiségü is él, Bánátban már jóval csekélyebb a számuk, Szerémségben pedig már elenyésző a magyar nyelvszigetek száma (GÁBRITY MOLNÁR I. 2008). Vajdaság öt községében a magyarság abszolút többséget alkot: Magyarkanizsán (Kanjiža), Zentán (Senta), Adán (Ada), Kishegyesen (Mali Iđoš) és Topolyán (Bačka Topola); továbbá relatív többségük figyelhető meg Szabadkán (Subotica), Csókán (Čoka) és Óbecsén (Bečej). ${ }^{20}$ A magyar nyelvet, mint anyanyelvet használó személyek Vajdaság területén, számszerüen a legtöbben Szabadkán, Magyarkanizsán, Bácstopolyán, Zentán és Óbecsén voltak. ${ }^{21}$

Vajdaság Autonóm Tartomány területén 467 település van, és ebből 389 településen írtak össze magyar nemzetiséghez tartozó egyéneket, míg 78 településen senki sem vallotta magát a magyar közösséghez tartozónak. ${ }^{22}$ Elemezve a településeket elmondható, hogy az

\footnotetext{
${ }^{16}$ Népszámlálási adatok alapján (RZS), 2011

${ }^{17}$ Republika Srbija: Treći periodični izveštaj o primeni Evropske Povelje o regionalnim ili manjinskim jezicima u Rebuplici Srbiji, Beograd, decembar, 2014, 18. p.

${ }^{18}$ Népszámlálási adatok alapján (RZS), 2011

${ }^{19}$ Vajdasági magyar kulturális stratégia 2012-2018, Magyar Nemzeti Tanács, 2011

${ }^{20}$ Népszámlálási adatok alapján (RZS), 2011

${ }^{21}$ Republika Srbija: Treći periodični izveštaj o primeni Evropske Povelje o regionalnim ili manjinskim jezicima u Rebuplici Srbiji, Beograd, decembar, 2014, 18. p.

${ }^{22}$ Népesedési akcióterv 2013-2017, Magyar Nemzeti Tanács
} 
elmúlt tíz évben 91 településen növekedett a magyarok létszáma. ${ }^{23}$ Mindemellett a települések alkotta községeken belül (elsősorban a Tisza melléken és a tartomány periférikus fekvésü, elöregedés és emigráció sújtotta területein) 81 olyan település lelhetö fel, ahol a magyarok száma meghaladja a más nemzetiségüekét (Kocsis K. et al. 2006 ).

$\mathrm{Az}$ utóbbi évtizedekben több tényező befolyásolta negatív irányban a magyar kisebbség számát: az időről időre bekövetkezett elvándorlási hullámok, az asszimilációs folyamatok, a magyar családokban születő gyerekek alacsony száma (átlagos családnagyság csökkenése). A létszám-problematika általános jelleggel jelen van Európában, nem csupán a kisebbségeket érinti, a legtöbb európai ország természetes szaporulata csökkenő tendenciát mutat (HABILCSEK L. 2004). Az előző mondatban leírtak szerint, tehát a népességfogyás nem etnikai specifikum, mégis a születések számának csökkenésével kapcsolatban meg kell említeni, hogy a magyar nemzetiségüként regisztrált újszülöttek száma Szerbiában nagyobb mértékben csökken, mint az össznépességre jellemző átlag. ${ }^{24}$

2. táblázat: Magyar nemzetiségúek száma (fö) 1948-től 2011-ig a Szerb Köztársaság területén $^{25}$

\begin{tabular}{|c|c|c|c|c|c|c|c|c|}
\hline & \multicolumn{7}{|c|}{ Évszám } \\
\cline { 2 - 8 } & 1948 & 1953 & 1961 & 1971 & 1981 & 1991 & 2002 & 2011 \\
\hline $\begin{array}{c}\text { Magyar } \\
\text { nemzetiségúek } \\
\text { Szerbiában } \\
\text { (fó) }\end{array}$ & 433701 & 441907 & 449587 & 430314 & 390468 & 343800 & 293299 & 253899 \\
\hline
\end{tabular}

Forrás: Republika Srbija, Republički Zavod za Statistiku(RZS) - Stanovtištvo: Nacionalna pripadnost (Knjiga 1), 14.o. ${ }^{26}$

A népességfogyásért mintegy hetven százalékban az alacsony születésszám tehető felelőssé, hiszen általánosságban kijelenthető, hogy Vajdaságban egyre kevesebb gyermek születik. $^{27}$ A vajdasági magyarság körében 1960-as évek óta figyelhető meg negatív természetes szaporulat (GYÉMÁNT R. 2008). A hetvenes években stagnált a születések száma, de a nyolcvanas évektől ismét csökkenés következett be (2. táblázat). ${ }^{28}$ Badis kutatásai alapján 1991 és 2000 között 32559 újszülöttet, 2001 és 2010 közötti években pedig már csak 25354 magyar újszülöttet regisztráltak, azaz 22,1 százalékkal kevesebbet (BADIS R. 2012). A születésszám 2002 óta 2817-ről 2092-re csökkent, azaz negyedével születtek kevesebben 2011-ben, mint a 2002-es népszámláláskor. ${ }^{29}$ Itt meg kell jegyezni, hogy 2002 óta a

\footnotetext{
${ }^{23}$ Népesedési akcióterv 2013-2017, Magyar Nemzeti Tanács

${ }^{24}$ Népesedési akcióterv 2013-2017, Magyar Nemzeti Tanács

${ }^{25}$ Az adatok 1948-1981 között a Szerb Köztársaság teljes területére vonatkoznak, míg 1991-2011 között végzett népszámlálások adatai nem tartalmazzák Koszovó és Methóhija területének adatait (Forrás: Republika Srbija, Republički Zavod za Statistiku Stanovtištvo: Nacionalna pripadnost (Knjiga 1)).

${ }^{26}$ RZS:http://pod2.stat.gov.rs/ObjavljenePublikacije/Popis2011/Nacionalna\%20pripadnost-Ethnicity.pdf

${ }^{27}$ Népesedési akcióterv 2013-2017, Magyar Nemzeti Tanács

${ }^{28}$ Népesedési akcióterv 2013-2017, Magyar Nemzeti Tanács

${ }^{29}$ Népesedési akcióterv 2013-2017, Magyar Nemzeti Tanács
} 
születésszám mellett nagymértékben, legalább 7 ezer fővel csökkent a szülöképes korban lévő nők száma is (BADIS R. 2012). Az utóbbi tíz évben a népességfogyatkozás tendenciája mérséklődött, ami a halálozások számának csökkenésével magyarázható, hiszen halálozások száma 2002 és 2011 között 5907 föröl 4793 före csökkent, ami 19 százalékos csökkenést jelent. $^{30}$

A népesség kor szerinti összetétele összefügg a csökkenő természetes szaporodással, és ez jól tükrözi az elöregedés folyamatát a tartomány lakosai körében. A Vajdaság 1971-re és 1981-re vonatkozói korfái aránylag fiatal és gyarapodó népességet mutattak, hiszen az idősebb korosztály száma alacsonyabb volt, mint a fiataloké. A 1991-ben a népesség korösszetétele stabilnak volt mondható, majd ezt követően az idősek száma nagymértékben megnövekedett, és a 2002. évi korfa már tipikusan hagyma alakú volt, vagyis elöregedö társadalmat vetített előre (SZLÁvITY Á. 2007). A tartomány korfájához hasonlóan a vajdasági magyar társadalom is kedvezőtlen korszerkezettel rendelkezik (BADIS R. 2012). A Szerbiában élő magyar népesség korstruktúrájának alakulását az 4. ábra szemlélteti. A Szerbiai Statisztikai Hivatal által készített korfán megfigyelhető, hogy folyamatosan csökken a fiatalkorúak (0-14 év), és folyamatosan növekszik az időskorúak (60 év felett) aránya. Ennek oka legfőképpen a csökkenő natalitás miatti gyors elöregedés, illetve a migráció hatása. A vajdasági magyarság körében is nagyon fontos nyomon követni a népesség kor szerinti összetételét, hiszen ezekkel az adatokkal összefüggésben alapozhatóak meg például a beiskolázással összefüggő intézkedések.

\section{4. ábra: A Szerbiában élő magyar nemzetiségúek korfája, 2011}

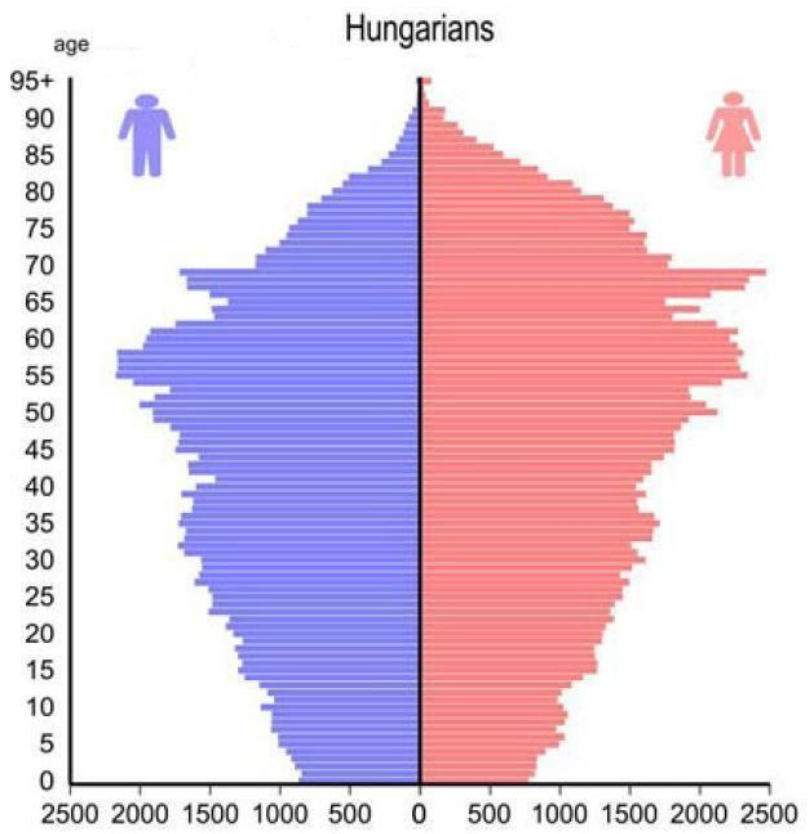

Forrás: Republika Srbija, Republički Zavod za Statistiku (RZS) - Stanovtištvo: Veroispovest, maternji jezik i nacionalna pripadnost (Knjiga 4), 33.o. ${ }^{31}$

\footnotetext{
${ }^{30}$ Népesedési akcióterv 2013-2017, Magyar Nemzeti Tanács

${ }^{31}$ RZS: http://pod2.stat.gov.rs/ObjavljenePublikacije/Popis2011/Knjiga4_Veroispovest.pdf
} 
A vajdasági magyarság közel kétharmada él a magyar etnikai tömb területén, nagy részük az Észak- Bácskai, és az Észak- Bánáti körzetben (BADIS R. 2011). A tömbterületen elő magyar közösség két fontos központjának Szabadka és Zenta tekinthető.

A vajdasági magyarság körében éppen azokon a területeken tapasztalható a legkisebb termékenységi arányszám, ahol a legnagyobb a koncentrációjuk (Tisza mente és ÉszakBácska), annak ellenére is, hogy ők mindennapi életük folyamán kevésbé kényszerülnek szembesülni a kisebbségi lét hátrányaival, szemben a szórványban élőkkel, ahol jóval magasabbak ugyanezek a mutatók, de összességében itt is, mint a vajdasági magyarság egészének körében a reprodukciót jelentő 2,1-es érték alatt maradnak. A termékenységi arányszám 2010-ben Észak-Bánátban 1,07, a Tisza mentén 1,20, Észak- Bácskában pedig 1,30 volt szemben Dél-Bácska 1,68-as értékével, ami a legmagasabb az említett évben (BADIS R. 2011).

A negatív természetes szaporulat mellett a migrációs veszteségek is a tömbben a legnagyobbak, hiszen az itt élök mobilisabbak (5. ábra). Ezekről a területekről (Szabadka és Tisza menti településekről) költöztek el a legtöbben Magyarországra az utóbbi években (BADIS R. 2011), illetve a fiatalok/egyetemi hallgatók is leginkább ezekről a területekröl mennek el Magyarországra továbbtanulni. Mindemellett a vajdasági magyar népesség évtizedek óta külföldön (föleg Ausztriában, Németországban és Svájcban) dolgozik vendégmunkásként. A nagyarányú kivándorlás károsan befolyásolta a Vajdaság, és ezen belül a magyar nemzetiségüek által lakott települések demográfiai és gazdasági fejlődését. A tartományból legintenzívebben a viszonylag fejletlen Dél-bánsági régióból, valamint a gazdasági és kulturális szempontból fejlett Észak-Bácskából vándoroltak ki (SZLÁVITY Á. 2007).

A vegyes házasságok és az asszimiláció jóval kisebb arányban figyelhető meg a tömbben, mint a szórványban. A vajdasági magyarság körében a Tisza menti településeken a legkisebb a vegyes házasságok aránya (7,3 százalék), hiszen ezen a területen a magyarok 80 százalék feletti abszolút többséget képeznek az összlakosságon belül (BADIS R. 2011).

A vajdasági magyarok közül többen élnek tömbben, mint szórványban. Gábrity Molnár Irén az előzőekben már felvetett meghatározása alapján szórványnak, vagy a szórvánnyá válás valamely fázisában lévőnek tekinthető a Bánátban, a Szerémségben és a Bácska déli, illetve nyugati részén élő magyarság. Mindemellett egyes vajdasági magyar többségű települések is a szórvány részét képezik (pl. Ürményháza (Jermenovci)). A vajdasági magyarok hozzávetőlegesen 37 százaléka él szórványterületen (GÁBRITY MOLNÁR I. 2005a).

A vajdasági magyarság körében a legmagasabb és a legalacsonyabb mértékü népességfogyás is a szórványban élők esetében volt megfigyelhető. A szórvány területeken élők a 2011-es népszámlálás alkalmával többen vallották magukat magyarnak adott esetben olyanok is, akik eddig jugoszlávnak tartották magukat (pl. Belcsény (Beočin) és Ópázova (Stara Pazova) község). A szórványmagyarság másik véglete, ahol 20-30 százalékos népességcsökkenést jegyeztek fel (pl. Sid (Šid), Alibunár (Alibunar), Hódság (Odžaci községek), ennek oka főleg a rendkívül alacsony születésszám és az asszimiláció voltak. A tömbben élö magyar közösségek esetében 10-15 százalék körüli fogyatkozás volt tapasztalható (Szabadka, Magyarkanizsa, Zenta, Ada községek). ${ }^{32}$

${ }^{32}$ Népesedési akcióterv 2013-2017, Magyar Nemzeti Tanács 
A szórványterületeken az asszimiláció felgyorsult, ami elsősorban a vegyes házasságoknak, valamint egyes településeken a magyar nyelvü oktatás hiányának tudható be. A vegyes házasságok száma Vajdaságban az elmúlt időszakban növekvő tendenciát mutat, különösen a szórványterületeken. Az utóbbi 10 évet vizsgálva megállapíthatjuk, hogy a vegyes házasságok száma 27-28 százalék körül mozog. A magyar nők által kötött vegyes házasságok aránya az összes megkötött házasság arányában valamivel magasabb (30 százalék), mint a férfiak által kötöttek (25 százalék). A vegyes házasságokat tekintve számolni kell az etnikai reprodukciós veszteséggel is, ami azt jelenti, hogy a megszülető gyermek feltehetően nem magyar nemzetiségűként lesz regisztrálva. ${ }^{33}$ A statisztikai adatok azt mutatják, hogy a szórványban több gyermeket vállalnak a magyar nők, ez azonban nem növeli a magyar lakosság számát az asszimilációs veszteség miatt, hiszen a szórványban a vegyes házasságok száma magasabb, és vélhetően ezekből a házasságokból születő gyermekek már nem a kisebbségi közösség tagjait bővíti. ${ }^{34}$

A fenti adatokból kitünik, hogy a jövőre nézve a földrajzilag koncentrált, túlnyomórészt helyi többségben élő tömbmagyarság fennmaradása valószínüsíthető, míg a szórványban élők száma (részleges újratermelődése ellenére) továbbra is erőteljes csökkenést fog mutatni (TÁTRAI P. 2017b).

5. ábra: Tömb- és a szórványmagyarság elvándorlását és asszimilációját szemléltető ábra
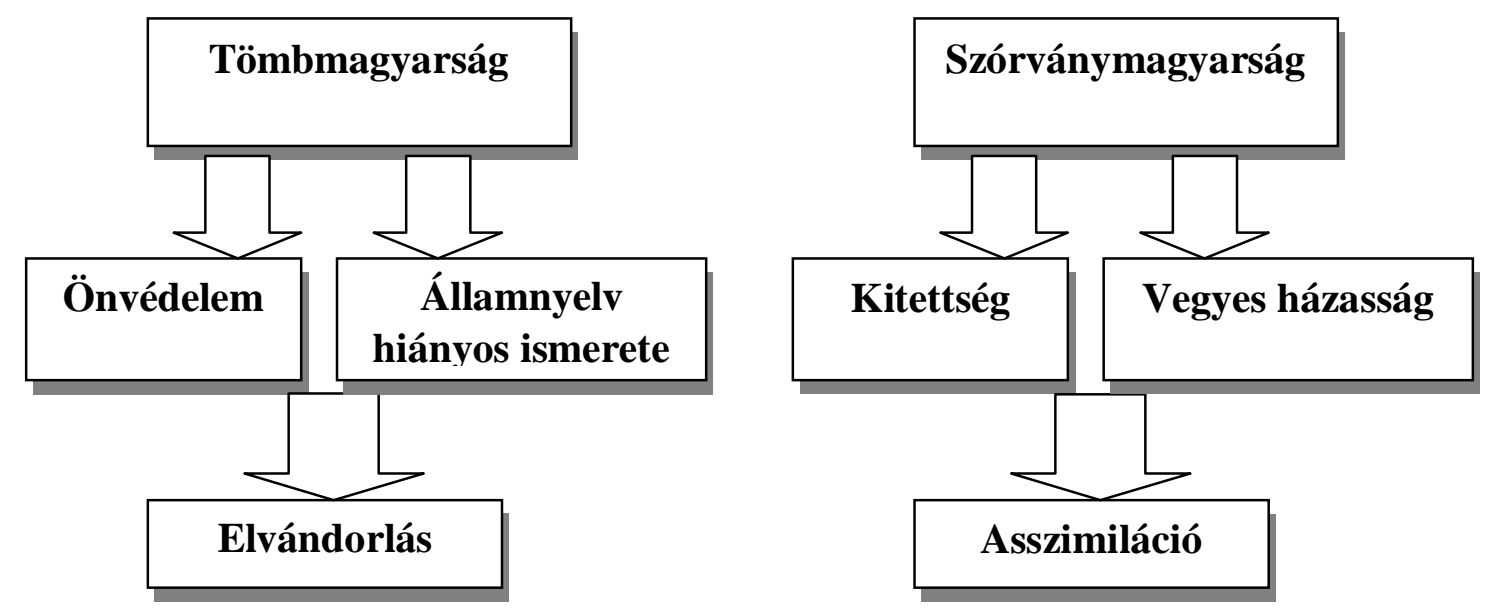

Forrás: saját szerkesztés

\section{A vizsgált területek bemutatása (Nagykikinda, Újvidék, Zombor)}

Jelen kutatás az oktatással kapcsolatos társadalmi és kulturális folyamatokat elemzi, amely folyamatok térbeli egységekhez, településekhez (községközpontokhoz) kötődnek, amelyek sajátos ismérvekkel bírnak, ezért fontos a mintaterületek földrajzi jellemzőinek és lokális viszonyainak az ismertetése.

\footnotetext{
${ }^{33}$ Népesedési akcióterv 2013-2017, Magyar Nemzeti Tanács

${ }^{34}$ Népesedési akcióterv 2013-2017, Magyar Nemzeti Tanács
} 
A nagykikindai község földrajzilag Vajdaság bánáti tájegységében helyezkedik el. A teljes község összesen tíz kisebb településböl áll, melynek központja Nagykikinda. A községközpont közigazgatásilag az Észak-bánsági körzet központja is egyben. A 2011-es népszámlálási adatok alapján, a község területén összesen 59453 fó élt, míg a községközpontnak 38065 lakosa volt. A községhez közigazgatásilag a következő települések tartoznak: Basahíd (Bašaid), Bánátnagyfalu (Banatsko Veliko Selo), Homokrév (Mokrin), Nákófalva (Nakovo), Szaján (Sajan), Tiszahegyes (Iđos), Torontáloroszi (Rusko Selo), Torontáltószeg (Novi Kozarci), Töröktopolya (Banatska Topola) (6. ábra).

A községhez tartozó falvakban és a községközpontban is etnikailag a magukat szerb nemzetiségünek vallók vannak többségben. A teljes község területén a magyarság részaránya 20 százalék alatt van. Nagykikindán összesen 4 504-en vallották magukat magyar nemzetiségünek, tehát a magyarok részaranya az össznépességhez viszonyítva 12 százalék volt. ${ }^{35}$ A nagykikindai magyarság kulturális élete szempontjából meghatározó jelentőségű az Egység Müvelődési Egyesület.

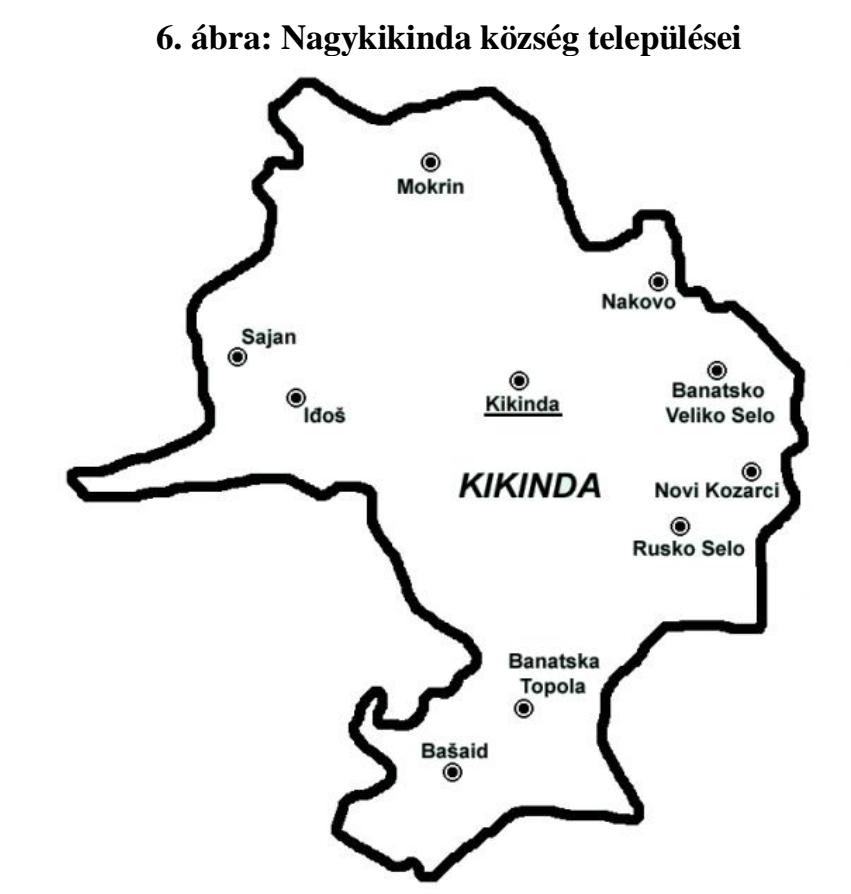

Forrás: http://vajdasag.rs alapján szerkesztette Trombitás Tímea

Újvidék város Vajdaság Autonóm Tartomány székvárosa és a Dél-bácskai körzet központja is egyben. Lakosságszáma szerint a második legnagyobb város Szerbiában. Földrajzilag Vajdaság középső részén, Bácska és Szerémség tájegységek határán helyezkedik el. Újvidék városi község két részből áll Újvidék és Pétervárad, melyeket a következő települések alkotnak: Újvidék (Novi Sad), Begecs (Begeč), Csenej (Čenej), Futak (Futog), Hadikliget (Veternik), Kabol (Kovilj), Káty (Kać), Kiszács (Kisač), Máriamajor (Stepanovićevo), Piros (Rumenka), Tiszakálmánfalva (Budisava), Pétervárad (Petrovaradin),

35 A 2011-es népszámlálási adatok alapján 
Bakolc (Bukovac), Kamanc (Sremska Kamenica), Ledince (Ledinci), Óledince (Stari Ledinci) (7. ábra).

Újvidék egy olyan multikulturális település, amely nemcsak földrajzi elhelyezkedésének, hanem gazdag történelmének is köszönheti nyelvi sokszínüségét. A 2011es népszámlálási adatok alapján a község területén összesen 341625 fő élt, míg a községközpontnak 307760 lakosa volt. A községhez tartozó falvakban és a községközpontban is a magukat szerb nemzetiségünek vallók vannak többségben. A teljes község területén a magyarság részaránya 5 százalék alatt van. Újvidéken összesen 12637 vallották magukat magyar nemzetiségünek, tehát a magyarok részaranya az össznépességhez viszonyítva megközelítőleg 4 százalék volt. ${ }^{36}$

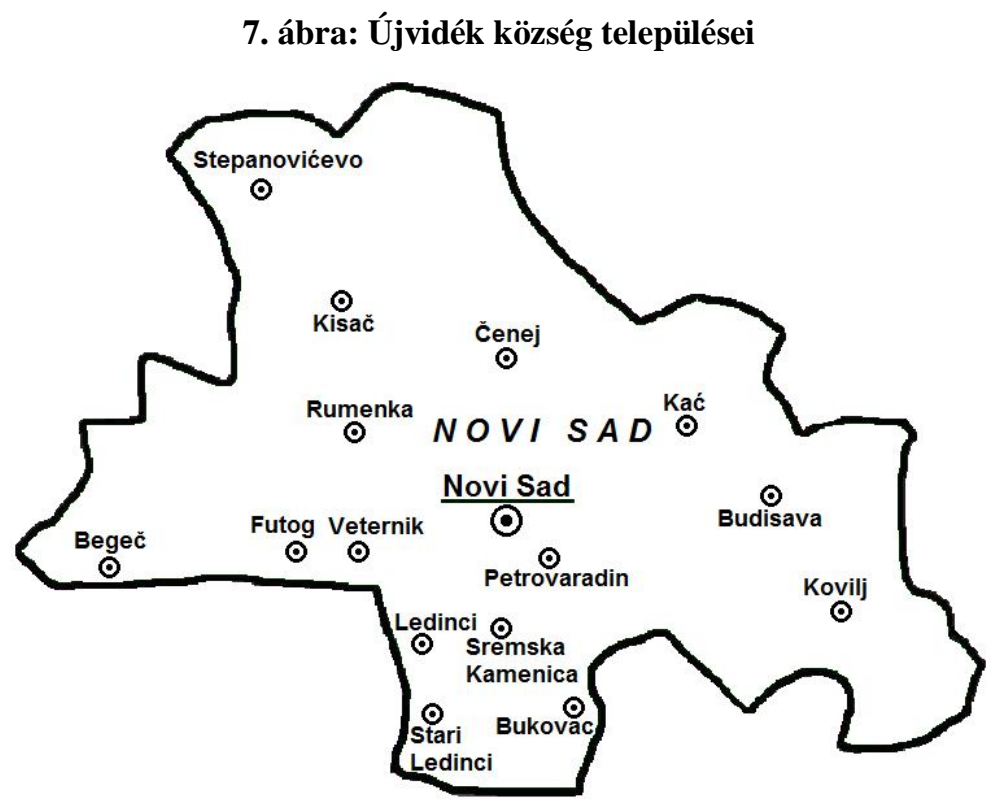

Forrás: http://vajdasag.rs alapján szerkesztette Trombitás Tímea

Zombor község a Nyugat-bácskai körzetben helyezkedik el. A község lakossága 2011ben 85903 fö volt, míg magában a községközpontban 47623 fó élt. A községhez közigazgatásilag a következő települések tartoznak: Babapuszta (Aleksa Šantić), Bácsgyulafalva (Telečka), Bezdán (Bezdán), Béreg (Bački Breg), Csonoplya (Čonoplja), Doroszló (Doroslovo), Gádor (Gakovo), Haraszti (Rastina), Kerény (Klajićevo), Küllőd (Kolut), Monostorszeg (Bački Monostor), Nemesmilitics (Svetozar Miletić), Örszállás (Stanašić), Regőce (Riđica), Sztapár (Stapar), Zombor (Sombor) (8. ábra)

Nyugat-Bácska Vajdaság azon régiói közé tartozik, ahol nagymértékben csökken a magyar lakosok száma. A város népessége állandó növekedést mutat, viszont a magyar nemzetiségüek száma és aránya csökken (NAGY I. et al. 2012). Az utolsó népszámlálás alkalmával 2011-ben Zombor községközpontban összesen 2851 fö vallotta magát magyar nemzetiségünek, tehát a magyarok részaranya az össznépességhez viszonyítva megközelítőleg

\footnotetext{
${ }^{36}$ A 2011-es népszámlálási adatok alapján
} 
6 százalék volt. ${ }^{37}$ A utolsó népszámlálást megelőzően, 2002-ben viszont az önmagukat magyarnak vallók 3743-an voltak.

Jelentős magyar intézmény a Magyar Polgári Kaszinó, amely több magyar nyelvű oktatási és kulturális programmal vesz részt a helyiek életében. Mindemellett a Kaszinó épülete ad helyet a Pécsi Tudományegyetem kihelyezett tagozatának, ahol a fiatalok ápolói szakon tanulhatnak magyar nyelven. A magyar közösség szempontjából az 1990-es évekig Doroszló, Bácsgyulafalva és Bezdán települések fejlett müvelődési élettel, és erősnek mondható általános iskolai hálózattal rendelkeztek. ${ }^{38}$ Több vajdasági településhez hasonlóan mára ezen említett települések is demográfiai problémákkal és az elvándorlásból származó nehézségekkel küszködnek.

\section{8. ábra: Zombor község települései}

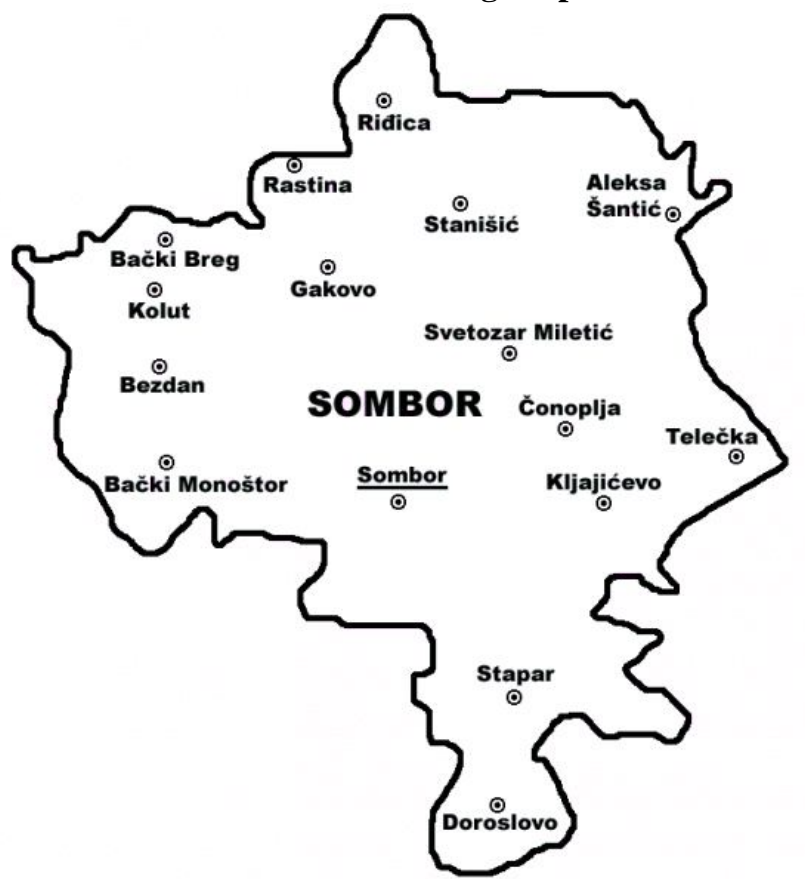

Forrás: http://vajdasag.rs alapján szerkesztette Trombitás Tímea

\section{Kisebbségi oktatás jellemzői Vajdaságban, különös tekintettel a magyar kisebbségre}

Szerbiában az alapszintű oktatásban való részvétel kötelező és tandíjmentes. Az általános iskolai oktatás, alsó (1.- 4. osztály) és felső (5. - 8. osztály) osztályokra tagozódik. Az általános iskolák állami alapításúak és az állam finanszírozza a múködésüket. A magyar közösséget érintő alapítói jog tekintetében annyi változás történt az utóbbi években, hogy a

\footnotetext{
${ }^{37}$ A 2011-es népszámlálási adatok alapján

${ }^{38}$ Esélyek és lehetőségek a vajdasági magyar szórvány felzárkózására (2005. június 30-án, a Mozaik Alapítvány szervezésében megrendezésre kerülő tanácskozása dokumentuma)
} 
Magyar Nemzeti Tanács egyes intézmények alapítói jogát átvehette, valamint egyes iskolákat kiemelt jelentőségű intézményekként kezelhet (SZÜGYI É. - TROMBITÁs T. 2013).

Szerbiában az oktatásról három jogi alapdokumentum rendelkezik, ezek a következők: Törvény az Oktatás és a Nevelés Alaprendszeréröl $(2003 / 04)^{39}$, Törvény a Középiskolákról (2003 és 2005) ${ }^{40}$, valamint Törvény a Felsőfokú Oktatásról (2005) (RÁCZ L. 2008). Az oktatásügy a 2002.évi törvénykezéseknek köszönhetően részben decentralizálttá vált, ezáltal az oktatás közigazgatása immár kiterjed a Tartományi Oktatási és Müvelődési Titkárságra, illetve az önkormányzatokra is (GÁBRITY MOLNÁR I. 2008b).

A Törvény ${ }^{41}$ értelmében az oktatás egy- vagy kétnyelvű. Szerbiában az oktatás alapvetően szerb nyelven történik, mindemellett, meghatározott feltételek mellett a nemzeti kisebbségek nyelvén is megszervezik a tanulók oktatását (FILIPOVIĆ, J. et al. 2008). ${ }^{42}$ Azoknak a tanulóknak is joguk van anyanyelvük ápolására, akik anyanyelvén nincs megszervezve az oktatás (ukrán, macedón, bolgár, roma, bunyevác). A vajdasági általános iskolákban az oktatás és nevelés a fentiekben már említett hat tannyelven folyik: szerb, magyar, szlovák, román, ruszin és horvát nyelven, valamint kétnyelvüen - szerb nyelven és valamelyik nemzeti kisebbségi nyelven. ${ }^{43} \mathrm{Az}$ anyanyelv, a nemzeti kultúra elemeivel választott tantárgy a felsorolt nyelveken kívül ukrán és roma nyelven is választható.

A kisebbségi tannyelven történő oktatás szervezésénél figyelembe veszik a gyereklétszámot, és a szükséges tanerő meglétét. Tizenöt tanuló jelentkezése esetén az intézmény köteles kisebbségi nyelvü osztályt nyitni, ennél kevesebb jelentkező esetén pedig engedélyezhető a kisebbségi nyelvü tagozat megnyitása egy-egy iskolában. Vajdaságban 539 általános iskolában és 110 középiskolában folyik valamely (esetleg több) nemzetiség nyelvén oktatás, viszont évről évre kevesebb a kisebbségi nyelven tanuló diák (SZERBHORVÁTH GY. 2015).

Vajdaság sokszínü etnikai összetétele miatt az oktatási intézmények zöme egy-, vagy kétnyelvü, amelynek előnye és hátránya is van. Előnye, hogy a tanulók szünetekben és közös tevékenységeken, iskolai rendezvényeken folyamatosan találkoznak a többségi nyelvvel, és ezáltal nyelvi kommunikációjuk fejlődik, ami a későbbi munkaerö-piaci alkalmazkodáskor is fontos lehet számukra (GÁBRITY MOLNÁR I. 2008b). Azonban a kétnyelvü iskolák egyik hátránya, hogy a magyar osztályokban, ahol nincs megfelelő magyar tanerő átmenetileg, ami sokszor évekig eltarthat, államnyelven oldják meg az oktatást, ezzel hozható összefüggésbe, hogy a szórványban sokszor a tantárgyak egyharmadát-felét szerb nyelven tanulják a magyar gyerekek. Ilyen esetekben a szülök gyakran úgy döntenek, hogy a gyermekeiket inkább kezdettől fogva szerb osztályba íratják (GÁBRITY MOLNÁR I. 2008b).

Vajdaság jól kiépített, széles körü magyar tannyelvü általános iskolai hálózattal rendelkezik, ahol 77 általános iskolában van lehetőség magyar nyelven tanulni, ${ }^{44}$ valamint 39

\footnotetext{
${ }^{39}$ Zakon o osnovama sistema obrazovanja i vaspitanja=Sl. Gl. RS 62/03, 58/04, 58/04, i 62/04), "Sl. Glasnik RS", br. 88/2017 i 27/2018)

${ }^{40}$ Zakon o srednjem obrazovanju i vaspitanju ("Sl. glasnik RS", br. 50/92, 53/93, 67/93, 48/94, 24/96, 23/2002, 25/2002 - ispr., 62/2003 - dr. zakon, 64/2003 - ispr. dr. zakona, 101/2005 - dr. zakon i 72/2009 - dr. zakon), "Sl. glasnik RS", br. 55/2013 i 101/2017

${ }^{41}$ Zakon o osnovama sistema obrazovanja i vaspitanja

${ }^{42}$ A közoktatási törvény (7. szakasz) elöírja, hogy az iskola oktatási nyelve a szerb, de a nemzeti kisebbségek anyanyelvükön tanulnak, kivételes esetben szerb nyelven (Molnár Gábrity I. 2008).

${ }^{43}$ Zakon o osnovama sistema obrazovanja i vaspitanja

${ }^{44}$ Magyar Nemzeti Tanács 2011: Oktatásfejlesztési stratégia megvalósítása egy év távlatából
} 
állami és 1 egyházi középiskolában folyik magyar nyelvü oktatás (BERETKA K. 2012). A 2013/2014-es iskolaévben a Tartományi Oktatási, Közigazgatási és Nemzeti Közösségi Titkárság adatai alapján összesen 26 önkormányzat 73 általános iskolájában 14.828 diák tanult magyar tannyelven, ezek közül 1.828 első osztályban. Ugyanezen adatok szerint 3295 magyar nemzetiségü diák többnyire szerb nyelven tanult, közülük 401 elsős (JOÓ HORTI L. et al. 2014). A 401 elsősből 108-an olyan önkormányzat területén élnek, ahol már nem elérhető a magyar oktatás, 293-an olyan önkormányzatban, ahol rendelkezésre áll a magyar tannyelvü oktatás. A hivatkozott tanulmány szerint, a nem magyar nyelven tanuló magyar nemzetiségü diákok kb. 5\%-a él Vajdaság olyan területén, ahol már nem müködik magyar tannyelvü iskola, valamint iskolabuszokkal is elérhetetlen távolságban van a legközelebbi magyar osztály. Az elemzés szerint a diákok 14\%-a él olyan önkormányzatban, ahol legalább egy iskola indít magyar tannyelvü osztályt, igaz számos esetben ez nem a diák lakóhelyén található, ugyanakkor iskolabuszokkal elérhető távolságban van (JOÓ HORTI L. et al. 2014).

A statisztikai adatok arról tanúskodnak, hogy függetlenül attól, hogy tömb vagy szórvány területről van-e szó, az anyanyelvükön tanuló magyar elsősök száma is folyamatosan csökken. Vajdaságban, a 2011/2012-es tanévben 1.927 tanuló, a 2012/2013-as tanévben 1.793 tanuló, 2013/2014-es évben 1.828 tanuló, 2014/2015-ös évben pedig 1.586 tanuló kezdte el az első osztályt. ${ }^{45}$ A legfrissebb iskolastatisztikai adatok szerint a 2016/2017es évben pedig 1521 magyar nemzetiségü kisdiák kezdte meg az első osztályt. A gyermeklétszám csökkenése miatt, Vajdaság szerte a nagyobb létszámú iskolákban csökkent a párhuzamos osztályok száma, és az egyes osztályok létszáma is, valamint több iskolában évről évre kérdéses a magyar osztályok megnyitása. ${ }^{46}$ A már említett problémákon kívül (a lakosság elöregedése, a születések számának csökkenése, kivándorlás, és a vegyes házasságok/asszimiláció) a gyermeklétszám csökkenésénél szerepet játszik még a szülök egy részének bizalmatlansága a magyar tagozatok nyújtotta lehetőségek iránt a gyermek életpályájának biztosítása terén. ${ }^{47}$

Azoknak a magyar nemzetiségü diákoknak, akik szerb tannyelvü osztályokban tanulnak, lehetőségük van részt venni az anyanyelvápolás órán, amely fakultatív (nem kötelezö). A magyar nyelvet, mint választható tantárgyat, főleg azon tanulók számára vezették be, akik vegyes nemzetiségü családból származnak, illetve azon tanulók számára, akiknek szülei magyar nemzetiségüek, de a továbbtanulás sikerességét abban látták, hogy szerb tagozatra íratták gyermeküket (TAKÁCS I. 2011).

A magyar általános iskolások körülbelül 20 százaléka tanul szerb nyelven (3. táblázat). A tömb területen (pl. Adán, Zentán, Magyarkanizsán) a magyar nemzetiségü gyerekek megközelítőleg 99 százaléka tanul magyarul, míg a szórványban (pl. Újvidék, Zombor, Nagykikinda) viszont csupán a fele, de egyes szórvány településeken, a szerb tannyelven tanuló magyar diákok aránya az 50 százalékot is messze meghaladja. ${ }^{48}$ Az oktatást illetően több szórvány településen, mint például Apatin (Apatin), Kúla (Kula), Hódság (Odžaci), Verbász (Vrbas), Fehértemplom (Bela Crkva), Versec (Vršac), Antalfalva (Kovačica),

\footnotetext{
${ }^{45}$ Informacija o upisu učenika u prvi razred osnovne škole u AP Vojvodini u školskoj 2014/15 godini

${ }^{46}$ Oktatási helyzetkép: A Vajdasági Magyar Pedagógusok Egyesülete évi közgyülésén elfogadott zárónyilatkozat, 2016.11.11.

${ }^{47}$ Oktatási helyzetkép: A Vajdasági Magyar Pedagógusok Egyesülete évi közgyülésén elfogadott zárónyilatkozat, 2016.11.11.

${ }^{48}$ Oktatásfejlesztési Stratégia 2010-2016, MNT
} 
Zichyfalva (Plandište), Szécsány (Sečanj), és Begaszentgyörgy (Žitište) évről évre bizonytalan a magyar osztályok megnyitása és fenntartása (GÁBRITY MOLNÁR I. 2002).

E fejezetben külön ki kell hangsúlyozni a falusi települések problémáit is, ahol szintén komoly nehézséget jelent a magyar tannyelvü iskolák megnyitása, mivel kicsi a lakosságszám, elöregedett a helyi népesség, és kevés a gyermek. Ezekben az iskolákban az osztályok kis létszáma nem csupán a tagozatok megnyitásánál jelent gondot, hanem a falusi iskolák fenntartásánál is, hiszen felmerül a kérdés, hogy vajon gazdaságos-e csupán néhány gyerek miatt müködtetni egy intézményt. Gyakran előfordul, hogy ezek az iskolák kevesebb támogatásban részesülnek, mint a városi intézmények, ez pedig könnyen vezethet a felszerelés elavulásához, a szemléltetőeszközök hiányához, kedvezőtlenebb feltételek kialakulásához. Mindemellett nagy hátrány a falusi iskolákban, hogy nincsenek helybeli (magyarnyelvü) tanárok, így a délutáni foglalkozások, különórák, csoporttevékenységek eleve kizártak (TROMBITÁS T. - SZÜGYIÉ. 2012).

3. táblázat: A magyar anyanyelvü diákok részvétele az alapszintü oktatásban 2014-ben

\begin{tabular}{|l|c|c|c|c|c|c|c|}
\hline Osztály & $\begin{array}{c}\text { Magyar } \\
\text { nemzetiségű } \\
\text { diák }\end{array}$ & $\begin{array}{c}\text { Magyarul } \\
\text { tanul }\end{array}$ & $\%$ & $\begin{array}{c}\text { Más } \\
\text { nyelven } \\
\text { tanul }\end{array}$ & $\%$ & $\begin{array}{c}\text { Más nemzetiségü } \\
\text { vagy nem } \\
\text { nyilatkozik, de } \\
\text { magyarul tanul }\end{array}$ & $\%$ \\
\hline 1 & 2109 & 1708 & 81 & 401 & 19 & 120 & 6,6 \\
\hline 2 & 2051 & 1647 & 80 & 404 & 20 & 122 & 6,9 \\
\hline 3 & 2222 & 1755 & 79 & 467 & 21 & 123 & 6,5 \\
\hline 4 & 2254 & 1849 & 82 & 405 & 18 & 113 & 5,8 \\
\hline 5 & 2312 & 1876 & 81 & 436 & 19 & 120 & 6,0 \\
\hline 6 & 2127 & 1767 & 83 & 360 & 17 & 108 & 5,8 \\
\hline 7 & 2166 & 1740 & 80 & 426 & 20 & 60 & 3,3 \\
\hline 8 & 2076 & 1680 & 81 & 396 & 19 & 42 & 2,4 \\
\hline
\end{tabular}

Forrás: Trombitás T.- Szügyi É. (2014)

\subsection{Tannyelvválasztási stratégiák tömbben és szórványban}

Több szempontból különbséget kell tenni a tömb- és a szórványterületek között. Elsősorban fontos különbség, hogy a tömbterületek településein (pl. Magyarkanizsa, Zenta, Ada, Kishegyes) általában a magyar nemzetiségü gyerekek nagyon alacsony szinten beszélik a szerb nyelvet, ami különböző objektív és szubjektív tényezőkre vezethető vissza. A szerb nyelvvel kapcsolatos hiányosságokat és lemaradást az iskolákban már nem tudják „,behozni” a tanulók, ugyanis a szerb nyelv, mint környezetnyelv tanítása nem illeszkedik megfelelően a nyelvtanulási igényekhez. Több szülő és pedagógus is úgy véli, hogy a tömbben élő gyerekek számára nem megfelelő az iskolában előírt program, hiszen az órákon komoly szerb nyelvü irodalmi szövegeket értelmeznek olyan diákok, akik a hétköznapi beszédet sem értik meg igazán. Ehhez kapcsolódóan több tanulmány foglalkozott már azzal, hogy a Kárpát-medence más, többségében magyar nemzetiségüek által lakott régióiban is, a gyermekek alacsony 
szinten beszélik az államnyelvet, és ezen mihamarabb változtatni kellene (SoRBÁN A. 2000; LANSTYÁK I. - SZABÓMIHÁLY G. 2002; ÁRENDÁS Zs. 2012; HíRES-LÁSZLó K. 2016).

Szerbhorváth (2015) tanulmányában leírtak szerint a magyar kisebbség hiányos államnyelvtudásának oka egyrészt a médiahasználat, hiszen a magyar nyelvü televízió müsorokat és sajtót követik, másodsorban szerb kortársaikkal alig érintkeznek/beszélgetnek. További okként hozzáteszi, hogy a szerb nyelvet környezetnyelvként tanítják, nem pedig idegen nyelvként, emiatt az oktatásügyi szakemberek a tananyagot ehhez mérten szerkesztik, hiszen feltételezéseik szerint a kisebbségi gyerekek megfelelő alapokkal rendelkeznek, s így azonnal nehezebb anyaggal indul az oktatás. E probléma kezelésére az oktatási minisztériumban külön egységet alakítottak ki, hogy a kisebbségi nyelveken tanulók új tankönyvhöz jussanak, hogy minél hatékonyabb legyen a szerb nyelv környezetnyelvként való oktatása (SZERBHORVÁTH GY. 2015). Ennek eredményét illetően a pedagógusok pozitív elörelépésröl adtak visszaigazolást.

A tömbben élő magyar nemzetiségü diákok gyenge szerb nyelvtudásuk miatt igyekeznek minél inkább „,kudarckerülő” magatartást tanúsítani, ami azt jelenti, hogy igyekeznek olyan egyetemi és fóiskolai szakokat választani, ami magyarul választható (MOLNÁR GÁBRITY I. 2007; SZÜGY É. 2010; ÁGYAS R. 2016). Tehát nem azt a hivatást választják, ami érdekli őket, hanem ami magyar nyelven tanulható Vajdaságban. Jellemző az is, hogy akik magyar nyelven végezték föiskolai vagy egyetemi tanulmányaikat nagyon nehezen kapcsolódnak be a szerbiai munkaerőpiacra hiányos nyelvtudásuk miatt. Mindemellett sokan a magyarországi továbbtanulás felé irányulnak, ami megnöveli a végleges elvándorlás lehetőségét, és az ő estükben a hazatérés igen bizonytalan (ERÖSs Á. et al. 2011).

A tömbterülettel ellentétben a szórványterületeken általában ellentétes a helyzet, mert a gyermekek már fiatalon elsajátítják az államnyelvet, hiszen környezetükben többet vagy kizárólag a szerb nyelvet hallják, és emiatt gyorsan meg is tanulják. Számukra egyáltalán nem okoz gondot a szerb nyelven történő kommunikáció. A szórványban a többségi közeg dominál, itt hangsúlyosabb a szerb kapcsolati háló, tulajdonképpen a többségi dominancia egyfajta folyamatot indít el, ugyanis a szülőnek a tannyelvválasztás során döntenie kell az anyanyelve és a környezetnyelv között. Általánosságban elmondható, hogy a szórványterületeken élő magyarok esetében jellemző a kétnyelvüség, azonban ritka a balanszkétnyelvüség, hiszen az egyik nyelv dominál, és ez általában az államnyelv. Ezekben a térségekben a magyar anyanyelvü diákok jelentős része szerb nyelven végzi tanulmányait, emellett a magyar kötődésü gyermekek jelentős aránya nem magyar anyanyelvü. A Magyar Nemzeti Tanács által készített kutatások is alátámasztották, hogy a magyar anyanyelvünek bejegyzett, de szerbül tanuló gyerekek nagy része nem, illetve nagyon alacsony szinten beszél magyarul. A szórványban jelentkező, a magyar kisebbség oktatásával kapcsolatos problémákat igyekeznek a lehetőségekhez mérten megoldani. A megoldásokat gyakran az összevont osztályok és az iskolabusz szervezése jelenti, továbbá azokon a településeken, ahol magyar nyelvű oktatás „kikerül” az intézményes keretből, ott hétvégi iskolák szervezésével igyekeznek fenntartani a magyar nyelvü anyanyelvápolást.

Mindemellett a szerb tannyelvü osztályokat választó szülők úgy vélik, hogy gyermekük a későbbiekben a felsőoktatásban és a munkaerő-piacon is jobban tud majd érvényesülni, ha kezdettől fogva szerb nyelven tanul. Ehhez kapcsolódóan ki kell emelni azt is, hogy a vegyes házasságok során a gyermek iskoláját gyakran a szláv szülő nyelvéhez igazodva határozzák meg (GÁBRITY MOLNÁR I. 2005; GYÉMÁNT R. 2008).

A legtöbb szülő és pedagógus véleménye szerint kardinális kérdés, hogy egy kisebbségben élő gyermek milyen nyelven kezdi meg tanulmányait, hiszen ez lényeges 
tényezőként hat a későbbi fejlődésére és érvényesülésére, továbbá nyelvtudása vagy annak hiánya meghatározhatja későbbi munkaerő-piaci helyzetét is. Az Oktatásfejlesztési Stratégiában leírtak szerint is, Vajdaság területén az egyéni boldogulás és a sikeresség egyik fontos záloga a szerb, a magyar, és egyre inkább az angol (esetleg a német) nyelv együttes ismerete. ${ }^{49} \mathrm{Az}$ előzőekben leírtakat egy álláshirdetéssel szeretném alátámasztani (9. ábra), miszerint az említtet nyelvek ismerete fontos egy adott munka betöltésére a vajdasági munkaerőpiacon.

\section{9. ábra: Álláshirdetés, 2015}

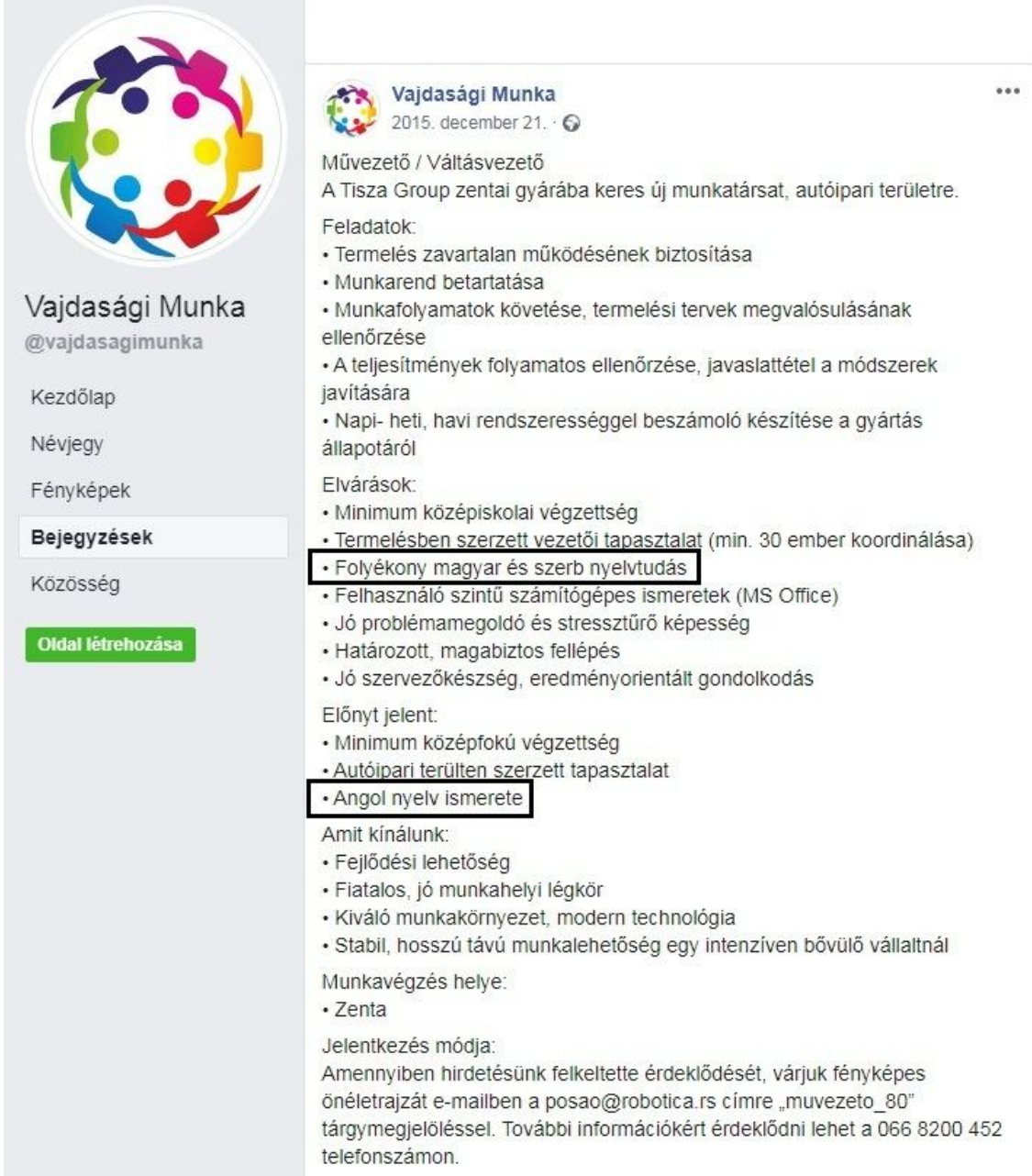

Forrás: https://www.facebook.com/vajdasagimunka/

\section{Az empirikus kutatás eredményeinek elemzése}

\subsection{A kutatás tapasztalatai Nagykikindán, Újvidéken és Zomborban}

A kutatás idején Nagykikindán a Fejős Klára Általános Iskolában és a Szent Száva Általános Iskolában volt lehetőség magyar nyelven tanulni (10. és 11. ábra). Mindemellett a

${ }^{49}$ Oktatásfejlesztési Stratégia 2010-2016, Magyar Nemzeti Tanács 
községen belül, Kisoroszban (Torontáloroszi (Rusko Selo)) ${ }^{50}$, Szajánban (Sajan) ${ }^{51}$, és Töröktopolyán (Banatska Topola) ${ }^{52}$ is folyik magyar nyelvủ oktatás. ${ }^{53}$ Középiskolai szinten a nagykikindai Müszaki Iskolában van mód magyar nyelven is tanulni. A kutatást követően azonban gyermekhiány miatt a két általános iskola tagozatait összevonták, így ma már csak egy intézményben, a Fejős Klára Általános Iskolában folyik magyar nyelvű oktatás. Mindemellett a kutatást követő években megszünt a középiskolai oktatás is, így azok a végzős magyar általános iskolás diákok, akik anyanyelvükön szeretnének továbbtanulni kénytelenek más városokban folytatni a tanulmányaikat, ami hátrányt jelent a magyar közösség számára. ${ }^{54}$

A kutatás során 13 interjút készítettem a vizsgálat helyszínéuil szolgáló Nagykikindán. A településen összesen hat iskola müködik, és ebböl ahogyan a fentiekben már említést tettem a kutatás időpontjában két iskolában lehet magyar nyelven tanulni (ezek nem kéttannyelvü iskolák, hanem önálló szerb és magyar nyelvü tagozatokon folyik a tanítás). A 13 megkérdezettből hat diák, négy szülő és három pedagógus volt. A szülőkkel készített interjú során egy esetben jelen volt a lekérdezett személy házastársa, illetve egy másik esetben jelen volt a megkérdezett szülő édesanyja is. A pedagógusok közül egy szerb nemzetiségü volt, aki szerb osztályokban tanít, egy magyar nemzetiségü, aki szintén szerb tannyelvü osztályokban tanít, míg a harmadik egy magyar nemzetiségü magyar tannyelvü osztályban tanító pedagógus volt. Az interjúk 2013. február és március hónap közötti időszakban készültek el. A 13 interjúból hét szerb nyelven, hat interjú pedig magyar nyelven készült. Az interjúalanyok felkutatásában egy nagykikindai általános iskolában dolgozó tanítónő segítségét kértem. Általa jutottam el a diákokhoz, valamint később a diákokon keresztül szüleikhez. A kutatás során nehézségekbe ütköztem, ugyanis a megkeresett hét szülőből mindösszesen négyen vállalták az interjút. A többieket a megadott telefonszámon nem tudtam elérni, vagy elfoglaltságukra hivatkozva nem kívántak felelni a kérdéseimre. A szerb tannyelvü osztályokban tanuló diákokkal az interjúk szerb nyelven készültek el, az ő saját kérésükre. Ök úgy fogalmaztak, hogy nehezen megy a magyar nyelv, ezért inkább szerbül beszélnének. Az interjúk készítése közben viszont kiderült, hogy egy kisfiú kivételével a diákok alig, illetve nagyon gyengén beszélnek magyarul.

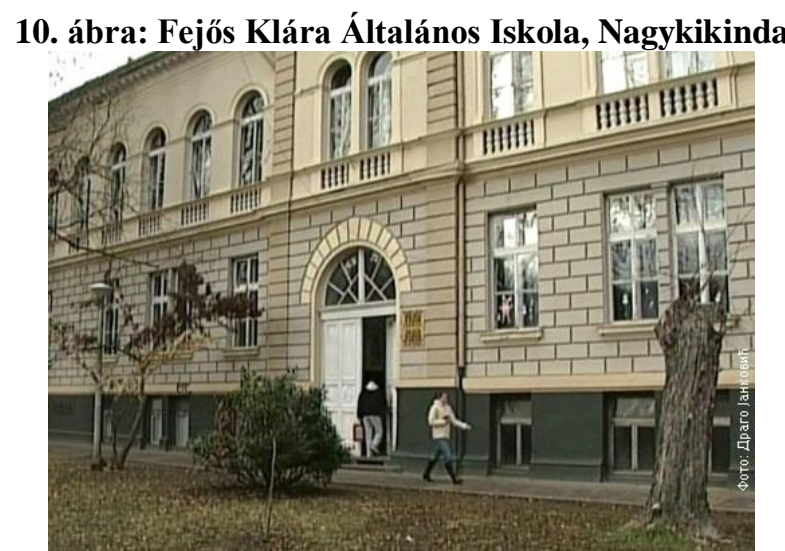

Forrás: https://ilovekikinda.com/vesti/1145-nastav-u-novim-ucionicama

\footnotetext{
${ }^{50}$ Gligorije Popov Általános Iskola

${ }^{51}$ Móra Károly Általános Iskola

${ }^{52}$ Testvériség - Egység Általános Iskola

${ }^{53}$ Észak-Bácskai Magyar Pedagógusok Egyesületének adatai alapján

${ }^{54}$ Magyar Szó napilap, 2012.07.12.
} 


\section{1. ábra: Szent Száva Általános Iskola, Nagykikinda}

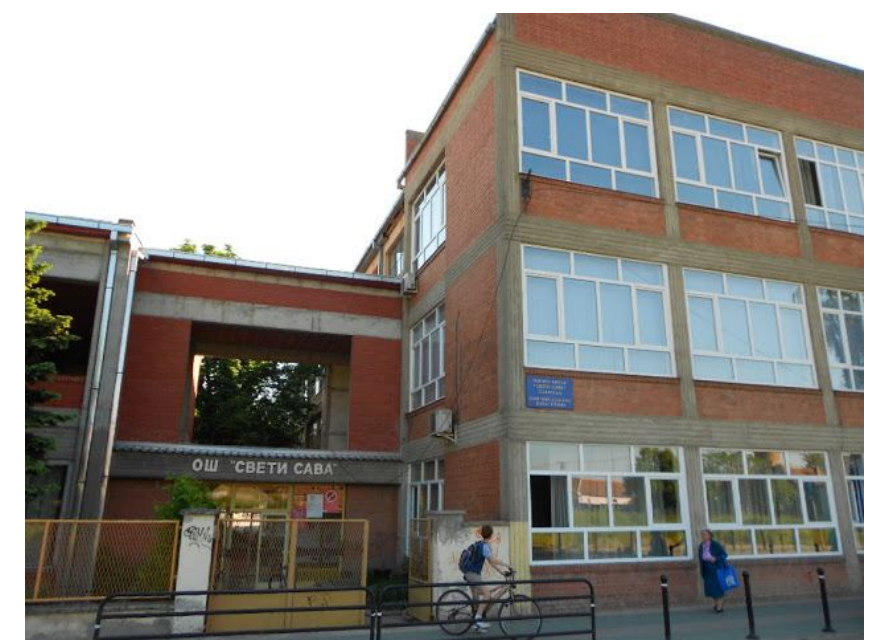

Forrás: http://osnovneskole.edukacija.rs/drzavne/kikinda/os-sveti-sava

Az Újvidéken készült interjúk 2014. szeptember és október hónap közötti időszakban készültek el. A kutatás során 14 félig strukturált interjú készült, melyböl hat szerb nyelven, nyolc interjú pedig magyar nyelven került lekérdezésre. A nagykikindai kutatáshoz hasonlóan a diákok kérésére az interjúk szerb nyelven készültek, egy kisdiák kivételével a többi tanuló igen gyengén beszél magyarul. A 14 megkérdezettböl öt diák, három szülő és hat pedagógus volt. A megkérdezett pedagógusok közül egy fö szerb nemzetiségü szerb tannyelvü osztályokban tanító tanár volt, továbbá a kutatásban részt vett négy magyar nemzetiségü pedagógus, aki egyaránt tanított szerb és magyar tannyelvü osztályokban is, illetve interjú készült egy alsó tagozaton tanító magyar pedagógussal is.

A kutatás időpontjában Újvidéken három általános iskolában volt lehetőség magyar nyelven tanulni, a Petőfi Sándor Általános Iskolában, a József Attila Általános Iskolában és a Sonja Marinković Általános Iskolában (12. 13. és 14. ábra), azzal, hogy a korábbi években a Nikola Tesla Általános Iskolában is müködött magyar nyelvü tagozat, de az utóbbi években az iskolában már nem indult első osztályos tagozat. Ezen felül az újvidéki községhez tartozó Piroson (Rumenka) ${ }^{55}$ és Tiszakálmánfalván (Budisava) ${ }^{56}$ szintén lehetőség volt magyar nyelven tanulni. ${ }^{57}$

A 2014/15-ös tanévben az Újvidék város területén müködő általános iskolákba összesen 37 gyerek iratkozott magyar tannyelvü tagozatra. A Petőfi Sándor Általános Iskolába 13 fơ, a József Attilába 9 fö, a Sonja Marinković Általános Iskolában 5, az Újvidék községhez tartozó tiszakálmánfalvi Ivo Andrić Általános Iskolában pedig 10 gyermek kezdte meg az első osztályt. ${ }^{58}$

A kutatás időpontjában a következő középiskolákban tudnak a diákok magyar nyelven továbbtanulni: Svetozar Marković Gimnázium, Mihajlo Pupin Elektrotechnikai Középiskola, Április 7. Egészségügyi Középiskola, Bogdan Šuput Képzőművészeti Középiskola, továbbá lehetőség van az újvidéki községhez tartozó Futakon (Futog) mezőgazdasági középiskolába

\footnotetext{
${ }^{55}$ Szent Száva Általános Iskola

${ }^{56}$ Ivo Andrić Általános Iskola

${ }^{57}$ Észak-Bácsaki Magyar Pedagógusok Egyesületének adatai alapján

${ }^{58}$ Újvidéken nőtt a magyar ajkú elsősök száma, Magyar Szó online, 2014.06.26.
} 
iratkozni. Bár a felsőoktatáshoz kapcsolódik, de fontosnak tartom kiemelni, hogy a kutatást követően 2015-ben Újvidéken megnyitották az Európa Kollégiumot, azzal a céllal, hogy megkönnyítsék a magyar anyanyelvü hallgatók lakhatását, és egyúttal a kollégium a vajdasági magyarság szellemi, tudományos és múvészeti központja kíván lenni. Mindemellett a kollégiumban helyet kapnak a magyarországi szerb közösséghez tartozó diákok is, így elösegítve a nemzetek közötti párbeszédet és egymás iránti toleranciát.

\section{2. ábra: Petőfi Sándor Általános Iskola, Újvidék}

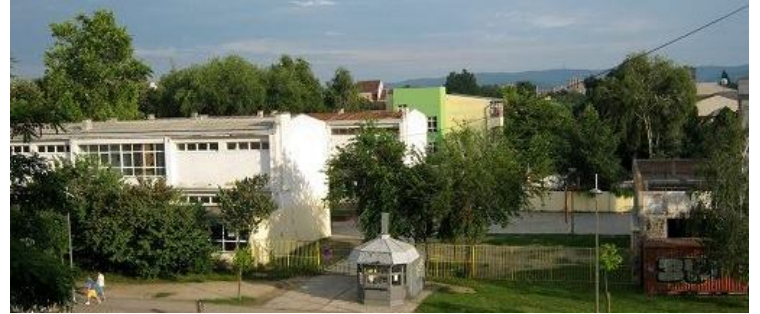

Forrás: http://osnovneskole.edukacija.rs/drzavne/novi-sad/os-petefi-sandor

\section{3. ábra: József Attila Általános Iskola, Újvidék}

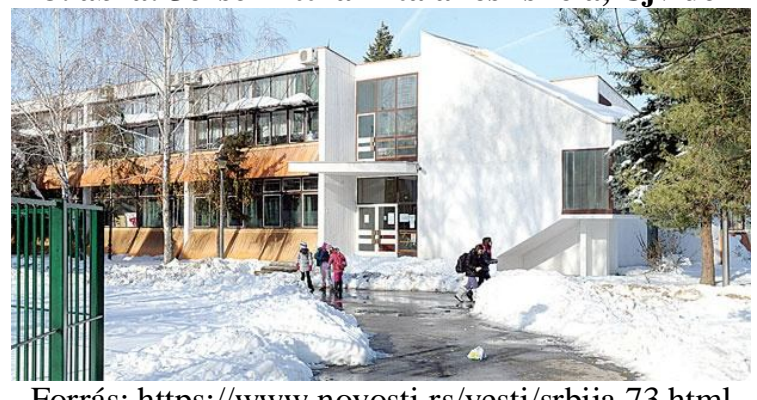

Forrás: https://www.novosti.rs/vesti/srbija.73.html

\section{4. ábra: Sonja Marinković Általános Iskola, Újvidék}

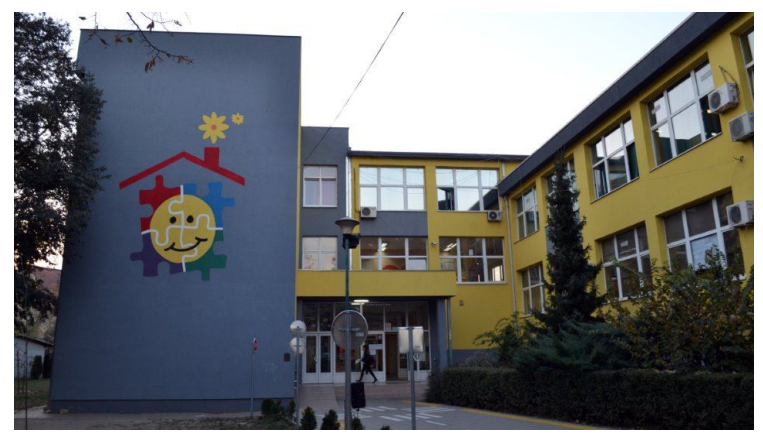

Forrás: http://www.sonjamarinkovicns.edu.rs/

A zombori interjúk 2014. november és december hónapok közötti időszakban készültek. A kutatás során 15 félig strukturált interjú készült. A 15 személyből nyolc pedagógus, három diák, és négy szülő volt. A nyolc pedagógus közül öt fő általános és középiskolában is tanít, három fó pedig kizárólag középiskolákban. A megkérdezett pedagógusok közül egy fő szerb nemzetiségü szerb tannyelvü osztályokban tanító tanár volt, hét fő pedig magyar vagy vegyes nemzetiségü pedagógus, aki egyaránt tanított szerb és magyar osztályokban is. A megkérdezett diákok vegyes nemzetiségü családból származtak. 
Zomborban az első interjúalanyom egy pedagógus volt, rajta keresztül kerültem kapcsolatban a többi pedagógussal, a pedagógusokon keresztül pedig a diákokkal és szüleikkel.

Zomborban egy iskolában, a Testvériség Egység Általános Iskolában van mód magyar nyelven tanulni (15. ábra). A zombori községen belül pedig Bácsgyulafalván (Telečka) ${ }^{59}$, Bezdánban (Bezdan) ${ }^{60}$, és Doroszlón (Doroslova) ${ }^{61}$ müködnek magyar osztályok. ${ }^{62}$ A zombori általános iskolában évről évre csökken a magyar diákok száma, ami komoly gondokat vet fel a jövöre nézve.

A kutatást követően elsős diák hiányában 2016-ban nem indult el a magyar tannyelvü osztály, ami korábban még nem fordult elő az iskola történetében, majd a következő évben (2017-ben) is csak két diák iratkozott magyar tagozatra. A 2019-es évben pedig szintén nem indult magyar első osztály. A folyamatosan csökkenő gyereklétszám a tanítók és tanárok normáját is súlyosan érinti. Egész Nyugat-Bácskában nő azon pedagógusok létszáma, akik több településen is dolgoznak, és sokan közülük míg így sem tanítanak teljes óraszámmal. Az általános iskolai tanulmányokat követően, a kutatás idöpontjában Zomborban a gimnáziumban, az egészségügyi, a közgazdasági és a müszaki középiskolában van lehetőség középfokon magyar nyelven továbbtanulni.

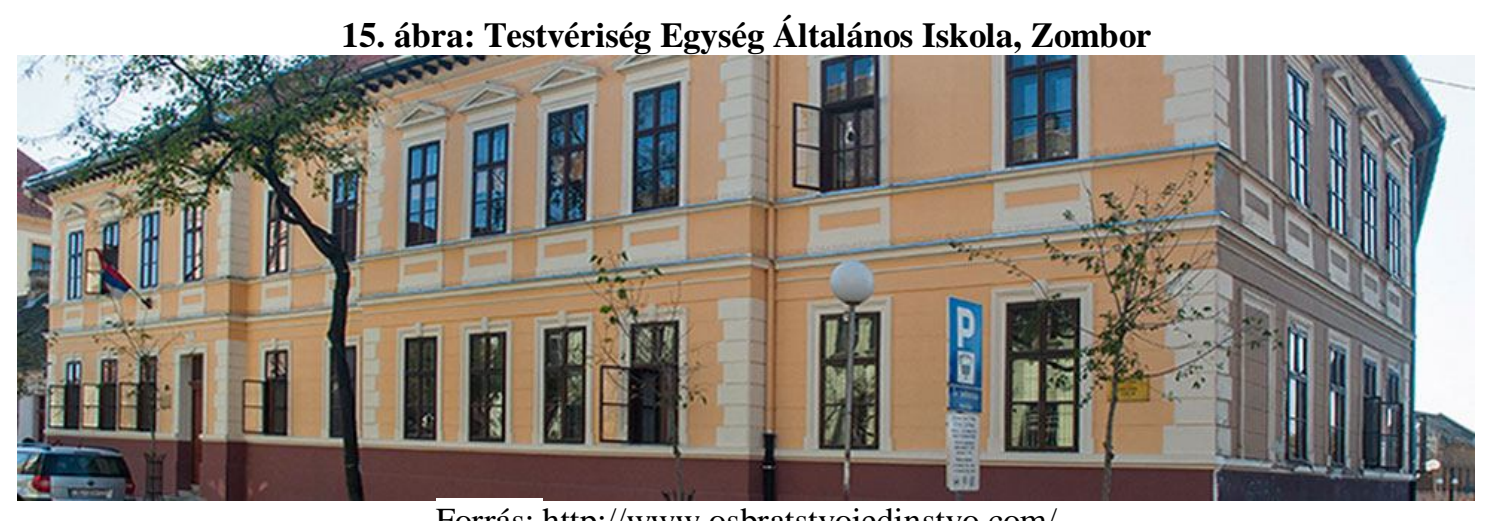

Forrás: http://www.osbratstvojedinstvo.com/

\subsection{Családi háttér és nyelvhasználat}

A megkérdezett diákok és szülök családi hátterét tekintve nagy többségük vegyes nemzetiségü családból származott (magyar-szerb). A három mintaterületen megkérdezett tanulók közül két diák (Nagykikindán és Újvidéken) kivételével nagyon gyengén beszélnek magyar nyelven. A diákok többségének elmondása szerint sokkal többet beszélnek szerbül, mint magyarul, a megkérdezett diákok a magyar szülővel, testvéreikkel és a magyar nagyszülőkkel is többnyire szerb nyelven beszélnek otthon. A megkérdezett tanulók, tehát családjukkal többnyire szerb nyelven beszélnek, és a magyar nyelvet ritkábban, vagy nem is használják, ennek következtében számukra nem jelentett gondot a szerb nyelven való tanulás. Ez alól egy újvidéki kisfiú képez kivételt, aki számára a szerb nyelv megnehezítette az iskolai közösségbe történő beilleszkedést.

\footnotetext{
${ }^{59}$ Kiss Ferenc Általános Iskola

${ }^{60}$ Testvériség egység Általános Iskola

${ }^{61}$ Petőfi Sándor Általános Iskola

${ }^{62}$ Észak-Bácsaki Magyar Pedagógusok Egyesületének adatai alapján
} 
Mindhárom mintaterületen a diákok mindegyike átlagos jövedelmi kategóriába sorolta családját, azaz nem tartotta családját sem gazdagnak, sem szegénynek. Egyik interjúalanyom így fogalmazott: „,.. normálisan élünk. Ha krízis van az országban, akkor nálunk is egy kicsit rosszabb, ha az országban jobb a helyzet, akkor nálunk is egy picit jobb..." (interjúrészlet, hetedik osztályos tanuló-K4, Nagykikinda, 2013).

A kutatásból kitűnik, hogy már a szülők esetében is a nyelvhasználat a szerb nyelv felé tolódott el. Több szülö azt mondta, hogy ök gyermekkorukban magyarul beszéltek a szüleikkel és a testvéreikkel, és az általános iskolát is magyar tannyelvü osztályokban végezték el. Ennek ellenére ezek a szülök ma már szinte csak szerbül beszélnek, egyrészt szerb nyelvü házastársuk vagy a rokonság/szomszédság miatt, illetve mindennapi munkájuk során is kizárólag a szerb nyelvet használják.

Többet beszélünk szerbül, mint magyarul. Vejem is szerb és a menyem is szerb. Értenek ök is magyarul, de ha velük vagyunk, akkor úgy kell beszélnünk, hogy ök is megértsenek, tehát szerbül. Az üzletben is többnyire a szerb nyelvet kell használnom, ha bejön egy magyar vevö, és magyarul köszön, akkor azzal magyarul beszélünk, de egyébként a szerbet használjuk, mert itt az emberek nagy része szerb. Keveset használjuk a magyar nyelvet..." (interjúrészlet, szülö-K12, Nagykikinda, 2013).

„... A gyerekek csak akkor hallanak magyar beszédet, ha én és a bátyám magunk vagyunk és ketten egymással magyarul beszélünk, de nagyon ritka az ilyen, mert már mi is megszoktuk a szerbet. Ha feleségem is itt van, ö nem érti a magyart, és e miatt úgy szoktuk meg, hogy szerbül beszéltünk. Feleségem nem tud magyarul, pedig az ö apja is magyar volt..." (interjúrészlet, szülö-K11, Nagykikinda, 2013).

„... Mi, az édesanyámmal magyarul beszélünk itthon egymás között, de a kislánnyal szerbül beszélünk, de néha van, amikor magyarul szólok neki, ö megérti, de szerbül válaszol vissza. Bár hallottam már egyszer-kétszer, hogy a magyar barátnőjével magyarul beszéltek..." (interjúrészlet, szülö-K10, Nagykikinda, 2013).

A szülők és a pedagógusok egybehangzóan nyilatkoztak arról, hogy általában a szórványterületeken, a domináns szerb nyelvü környezet miatt, a gyerekek már kiskoruktól kezdve nagyon jól beszélnek szerbül, illetve a pedagógusok nagy része arra hívta fel a figyelmet, hogy fontos az államnyelv megfelelő ismerete, ami ezeknél a gyermekeknél megvan, de emellett az is lényeges, hogy a magyar gyökerekkel is rendelkező gyerekek a magyar nyelvet is elsajátítsák, illetve szinten is tartsák azt.

„Olyan környezetben vagyunk, ahol állandóan, tehát nem tudja megkerülni azt, hogy szerbül ne beszéljen. Nincs olyan gyerek itt az iskolákban, aki ne tudna perfekt szerbül beszélni” (interjúrészlet, pedagógus-U3, Újvidék, 2014).

„... a családban a sógorom is szerb volt és a barátaink is szerbek...” (interjúrészlet, szülöZ13, Zombor, 2014).

„Kell beszélni a szerbet, hiszen Szerbiában élünk, de lényeges, hogy saját nyelvünket is beszéljük [magyart] ” (interjúrészlet, pedagógus-U5, Újvidék, 2014). 
A kisebbségi nyelv ismerete a család hozzáállását is tükrözi az adott kisebbségi nyelvhez/kultúrához. Több pedagógus kiemelte az apák dominanciáját egy családon belül. Véleményük szerint az apa nemzetisége és nyelvhasználata befolyásolja a gyermek későbbi nyelvválasztását, ha az apa a szerb nemzetiségü, és mivel ő tekinthető a családfönek (ö a domináns), ezért az apa által használt nyelv (szerb nyelv) kerül előtérbe. Ehhez kapcsolódóan, viszont kutatásom során azt tapasztaltam, hogy a vegyes nemzetiségü családoknál ha az apa magyar nemzetiségü volt, akkor gyermekei nem követték az apa nyelvhasználatát, tehát nem érvényesült az apa domináns helyzete.

„... tulajdonképpen a családtól függ, nem is annyira az iskolarendszertöl, hogy hogyan tanul meg a gyerek magyarul. Fontos az identitás, fontos, hogy az embernek legyen egy ösvénye, egy frontvonala, ami az övé... Vissza kell megint menni a családba, hogy például a férj milyen nemzetiségü, ez döntö szerepü” (interjúrészlet, pedagógus-U5, Újvidék, 2014).

A családi nyelvhasználatot továbbá nagyban meghatározzák a gyermekek személyes tapasztalatai is. Egy ilyen tapasztalatról mesélt egy édesanya, aki elmondta, hogy lánya nagyon jól beszél szerb nyelven, hiszen minden nap ezt a nyelvet használja, e nyelven tanul az iskolában is. A szülő elmondása szerint lánya magyarul is jól beszél, viszont fiatalabb korábban az iskolában magyar nyelvü társai kinevették hiányos magyar nyelv tudása miatt, ezért manapság már szorong, ha a magyar nyelvet kell használnia, bizonytalan lett nyelvtudásában, ezért nem szívesen használja a nyelvet.

A lányomnak a szerb nyelv nem gond, de magyarul is tud beszélni, de néha szégyelli magát. Egyszer kisebb korában, ha valamit nem jól mondott, akkor kinevették, és valószinüleg e miatt, nem akar magyarul beszélni. De ért magyarul, és tud is beszélni. Olvas magyarul, magyar tévét néz..." (interjúrészlet, szülö-K12, Nagykikinda, 2013).

Érdemesnek találom kiemelni egy újvidéki család történetét, ahol a szülők miután fiukat szerb tannyelvü iskolába íratták, ezt követően igyekeztek otthon is szerb nyelven beszélni, hogy a fiúk füle „mind inkább hozzászokjon” a szerb nyelvhez. Itt a szülők maguk kívántak változtatni az addig használt belső családi nyelvrendszeren. A család a mai napig többnyire szerb nyelven beszél, viszont érdekesség, hogy a két testvér egymás közt a magyar nyelvet használja.

„... itthon szinte majdnem mindig szerbül beszélünk a nagyobb gyerek miatt, viszont ők ketten egymás között [két testvér], mindig magyarul beszélnek. Viszont az érdekes, hogy én beszélek szerbül a fiamhoz, és mondok valamit a lányomnak is, azt is szerbül mondom, de ö magyarul válaszol vissza. Ha a fiam felidegesedik valami miatt, és elindul szerbül [beszélni], tehát automatikusan, mondjuk tanulás közben, és persze szerbül megy az egész, akkor felszól szerbül, de rögtön vált magyarra, meglátja a húgát, rögtön vált magyarra.” (interjúrészlet, szülö-U12, Újvidék, 2014).

$\mathrm{Az}$ interjúalanyok nagy része beszélt arról is, hogy a Vajdaságban élő legtöbb családnak vegyes etnikai háttérrel rendelkező felmenői voltak/vannak, hiszen a Vajdaság a történelem folyamán, és manapság is, több népnek az otthonát jelenti, amely magával hozta azt a helyzetet, miszerint az itt élők mindennapjaik során több nyelvet használnak, ami egy multietnikus környezetben teljesen természetesnek számít. Bár módszertanilag a pedagógusok által elmondottak más típusba sorolhatóak, mégis a leírtakat egy tanár szavaival is szeretném 
alátámasztani, mert ő foglalta össze legjobban a vajdasági családokban előforduló nemzetiségi sokszínüséget.

„... szóval mi itt nagyon-nagyon kevert társaság vagyunk. Én egy olyan családból, kevert családból vagyok, az anyukámnak az anyukája magyar volt, és az apja az német, úgyhogy én ilyen három nyelves családban nöttem föl. Az apukám horvát volt, az anyja német. Úgyhogy van mindenféle, és három nyelven úgy fölnöttem. De szerb iskolába jártam, és a magyarból én nem voltam, nem volt sok gond, amíg a nagyszülö élt...A férjem, ö is ilyen kevert származású, szóval a nagyapja, az német volt, az anyukája, az bunyevác...de magyarnak érezte magát" (interjúrészlet, pedagógus-Z6, Zombor,2014).

„Szerb szomszédjaink voltak, de nagyon vegyes a környezet itt nálunk. Vannak itt szerbek, magyarok, boszniaiak” (interjúrészlet, szülö-K11, Nagykikinda, 2013).

\subsubsection{Vegyes házasságból született gyermekek nyelvhasználata}

A kutatásban részt vett szülőket (főleg a vegyes házasságban élőket) a kétnyelvüség (a szerb nyelv volt domináns), és a kettős identitás jellemezte. Több esetben tapasztalható volt az is, hogy a szórványterületen domináló szerb kapcsolati háló következtében az évek során a belső családi nyelvi rendszer megváltozott, az otthon beszélt nyelv a többségi nyelv (szerb nyelv) lett.

A kutatásba bevont szülök közül, ha az anya volt szerb nemzetiségü, és az apa a magyar, akkor a legtöbbször a szülök azt mondták, hogy amiatt, hogy az anya többet van otthon és emiatt több időt tölt el a gyermekkel, ezért az anya révén inkább a szerb nyelv került előtérbe. Ezt a ,jelenséget” Árendás Zsuzsanna Délnyugat-Szlovákiában végzett kutatásáról írt munkájában ki is fejti, ahol a szülő társadalmi nemi (gender) szerepét, illetve az anyai szerep iskolaválasztással kapcsolatos lehetséges összefüggéseit vizsgálja. Árendás empirikus kutatása alapján a szülők annak alapján döntöttek az oktatási nyelv mellett, hogy a későbbiekben kinek a feladata lesz tanulni a gyermekkel (ÁRENDÁs Zs. 2012). A vizsgált településeken vegyes nemzetiségü családokban (is) tipikusan anyai feladatként reprezentálódott az otthoni lecketanulás (ÁRENDÁs Zs. 2012). Ugyanakkor az anya saját nehézségeiből kiindulva, és/vagy mert saját iskolai mintáját nem tartja kellően sikeresnek „fordíthat” is az iskolaválasztás korábbi mintáján a családban (ÁRENDÁs Zs. 2012). Ebből kifolyólag az anya nemzetisége és az, hogy ö milyen nyelven végezte tanulmányait, az iskolaválasztás során döntő szerepü lehet.

A szórványban, főleg a vegyes házasságból született gyermekek már többnyire szerb nyelven beszélnek, és a magyar nyelvet ritkábban vagy inkább nem használják. Ennek ellenére a megkérdezett tanulók esetében a magyar nyelvismeret szintje változó volt. A szórványban, a gyermekeket kevés magyar nyelvi hatás éri, és több család esetében a nyelvátadási funkció elveszett, emiatt a szülők egy része természetesnek tartotta, hogy a gyermeküket szerb osztályba íratták. Természetes dolog az, hogy ha vegyes házasságról van szó, akkor az számít „,normálisnak”, ha a gyerek nem magyar nyelven tanul, hanem szerbül.

„... Ha már az egyik szülő szerb, akkor természetesen már szerb osztályba megy a gyerek...” (interjúrészlet, pedagógus-Z5, Zombor, 2014). 
„Nagyon sok magyar szülö meg sem tanítja beszélni magyarul a gyermekét” (interjúrészlet, pedagógus-K3, Nagykikinda, 2013).

„Anya nem tud [magyarul], apa viszont tud magyarul, de sokszor nincs idő rá, mert dolgozik” (interjúrészlet, diák-U9, Ujvidék, 2014).

Egy zombori diák, akinek édesapja magyar nyelven végezte iskoláit, édesanyja pedig szerb nyelven tanult, arra a kérdésemre, hogy milyen nyelven beszélnek otthon, azt válaszolta, hogy csak szerbül, ő nem is tud olyan jól magyarul. A diák kiemeli, hogy testvére magyar nyelvet is tanul az iskolában, ekkor magyar anyanyelvü édesapja segít neki, ilyenkor szokta őt hallani magyar nyelven beszélni.

szerbül beszélünk otthon, csak szerbül, apával is. Apa csak segít néha a testvéremnek, mert ö tanul magyarul is, de én nem" (interjúrészlet, diák-Z10, Zombor, 2014).

Egy Nagykikindán vegyes házasságban élő szülő azt is elmondta, hogy sajnos a két gyermeke közül egyik sem beszél magyarul, és most már nagyon sajnálja, hogy ő, mint szülő erre nem figyelt oda korábban, mert jobb lenne, ha a gyermekei minél több nyelven beszélnének. A szülő kisebbik gyermeke, aki most a szerb tannyelvü osztály negyedikes tanulója nagy érdeklődést mutatott a magyar nyelv iránt, ezért egy éve külön magyar órákra jár. Az interjúk során az is elhangzott, hogy Nagykikindán gyakran előfordul, hogy a magyar családok is szerbül beszélnek otthon, de ez főleg a vegyes nemzetiségü családokra jellemző.

A nagyobbik fiam nem igazán érdeklödött a magyar nyelv iránt, pedig van neki egy magyar barátja is. Itt nálunk Kikindán elöfordul, hogy magyar a család, de a gyerekek már nem tudnak magyarul. Hiába vagyunk magyarok, mi már szerbül beszélünk, ritka az is, hogy mi is a bátyáimmal magyarul beszélünk, pedig gyerekkorunkban csak magyarul beszéltünk egymással..." (interjúrészlet, szülö-K11, Nagykikinda, 2013).

\subsection{Magyar tagozaton tanulók létszámának csökkenése}

Az elméleti részben említett demográfiai folyamatok nagymértékben befolyásolták a beiskolázás folyamatát, a magyar tagozaton tanulók létszáma jelentősen lecsökkent az utóbbi években/évtizedekben. A létszámfogyatkozás oka a magyar családokban születő gyerekek számának folyamatos csökkenése, valamint az egyes időszakokban bekövetkezett kivándorlási hullám. A gyerekek számának csökkenése nem etnikai jellegzetesség, ugyanis ez a tendencia az egész országra jellemző. A magyar tagozaton észlelhető csökkenéshez az is hozzájárul, hogy több magyar családból, illetve vegyes házasságból származó kisdiákot szerb tagozatra íratnak.

Az egyik pedagógus véleménye szerint, abban az iskolában, ahol ő tanít körülbelül 10 százalékra tehető azoknak a diákoknak a száma, akik magyar vagy vegyes (fóként magyarszerb) nemzetiségü családokból származnak, de szerb tannyelvü osztályokban tanulnak. Az egyik megkérdezett diák nagymamája úgy fogalmazott, hogy húsz évvel ezelőtt automatikusan a magyar gyerek magyar, a szerb pedig szerb nyelven tanult, de ez mára megváltozott.

„... Akkoriban, amikor a fiam elkezdett iskolába járni, akkor jobban ment a magyar, minden szülö azon volt, hogy magyar tagozatra adjuk a gyerekeket. Arra nem is gondoltunk, hogy amikor befejezik majd a nyolc osztályt, akkor talán nekik nehezebb lesz majd a 
középiskolában a nyelv miatt. Mi azzal voltunk, hogy magyarok vagyunk, és ezért magyar tagozatra adjuk a gyereket. A lányom és a fiam is magyar tagozatra járt, de unokáim most szerb tagozaton tanulnak..." (interjúrészlet, hatodik osztályos diák nagymamája-K14, Nagykikinda, 2013).

A nagykikindai mintaterületen eddig azok a szülök, akik magyar tagozatra szerették volna íratni gyermeküket dönthettek arról, hogy melyik iskolában taníttatják őket, viszont a 2013-as év szeptembertől már csak a Fejős Klára Általános Iskolában lehet magyar nyelven első osztályba iratkozni. A Fejős Klára Általános Iskolában a kutatás időpontjában az első osztályban nyolcan, a második osztályban hatan, a harmadik osztályban négyen, a negyedik osztályban pedig heten vannak (pedagógus-K3, Nagykikinda, 2013). Ennek következtében indokolttá is vált, hogy az eddigi két iskola helyett csupán csak az egyik iskolában szervezzék meg a magyar nyelvü oktatást.

„... amikor én jártam elemi iskolába, akkor két magyar és egy szerb tagozat volt a Fejös Klára iskolában, és a Szent Száva iskolában szintén, tehát összesen négy magyar tagozat volt. Ezek a diákok, most negyvenhét évesek. Ezeknek a volt diákoknak a gyerekei tizennyolctizenkilenc létszámú tagozatokba jártak tíz évvel ezelött, és ez a szám mostanra drasztikusan lecsökkent. Most a magyar tagozaton egy osztályban hat, hét diák van...” (interjúrészlet, pedagógus-K3, Nagykikinda, 2013).

„... most meséli a szomszéd kislány, aki magyar tagozatra jár, hogy ők az osztályában hatan vannak. Nagyon lecsökkent a gyerekek száma, de nem csak a magyar tagozatokon...”(interjúrészlet, szülö-K10, Nagykikinda, 2013).

A létszámfogyáshoz kapcsolódóan egy újvidéki alsóosztályokban tanító pedagógus arról panaszkodott, hogy a jelenlegi magyar nyelvü osztályában 8 kisdiákja van, véleménye szerint ez igen kevésnek számít, föleg az elmúlt évekhez viszonyítva. Tapasztalatai alapján az ideális osztálylétszám 15 fóből kellene, hogy álljon, mert meglátásai szerint, ezen létszám esetében több csoportos feladat elvégzésére lenne lehetőség.

„A magyar alsó osztályokban öt és tíz között van a létszám, így szokott mozogni, sajnos, most nyolc diákom van. Legalább tíz kellene, nehéz, mert kevesebb, mint tíz gyereknél nehéz csoportban dolgozni, jó volna, ha legalább tíz, tizenkét gyerek volna, de tizenöt volna az ideális" (interjúrészlet, alsóosztályban tanító pedagógus-U3, Újvidék, 2014).

Ehhez kapcsolódóan az újvidéki iskola tanárai éppen az alacsony létszám előnyeire hívták fel a figyelmet. Kifejtették, hogy a magyar tannyelvü osztályokban kevesebb diák tanul, mint a szerb osztályokban, és véleményük szerint ez az egyik legerősebb érv amellett, hogy a szülők gyermekeiket magyar tannyelvü osztályba írassák, hiszen a kevesebb létszámú osztályokban a tanár több időt tud fordítani egy-egy tanulóra, ami bizonyítottan elönyös a diákok számára.

legütösebb érv az, hogy kisebb osztályban sokkal könnyebb tanulni. A magyar diákokra egyenként több idö jut rájuk egy tanár részéröl, mert kevesebben vannak, és ezért sokkal jobban teljesítenek a felvételiken, záróvizsgákon is. Záróvizsgákon átlagban, a mi iskolánkból, 2,5 ponttal többet sikerül összegyüjteniük. Egész más 25 diákkal dolgozni vagy 15-tel vagy 10-zel. Ettöl erösebb érv szerintem nem kell. Aki ezt nem fogja fel, annak mesélhetek én, hogy 
milyen a magyar osztály és mi magyarok vagyunk, ezt én nem tartom érvnek, ez mindenkinek a saját érzésvilága, hogy ö magyarnak érzi magát vagy szerbnek vagy akármilyen más nemzetiségünek, vagy nem is tartja ezt fontosnak, az tény, hogy a kevesebb létszámú osztályban gyorsabb a haladás” (interjúrészlet, pedagógus-U2, Újvidék, 2014).

A fentiekhez kapcsolódóan a zombori mintaterületen végzett kutatás során arról az esetről is beszéltek, amely során egy vegyes házasságban élő szerb nemzetiségű szülő mindenképpen ahhoz ragaszkodott, hogy gyermeke magyar nyelven tanuljon, mert véleménye szerint, a kisebb osztálylétszámnak köszönhetően, a tanár több időt tud fordítani az osztályába járó diákokra, így gyermeke vélhetően színvonalasabb oktatásban részesülhet.

de voltak olyan esetek is, hogy kevert házasságból épp a szerb szülö volt az, hogy menjen magyar osztályba a gyerek, mert, hogy minöségesebb a tanitás, mert úgy gondolják, hogy talán jobb, mert kisebb létszámúak az osztályok..." (interjúrészlet, pedagógus-Z1, Zombor, 2014).

A kutatásba bevont mintaterületeken a szülők és a pedagógusok egybehangzóan a létszámfogyás és a magyar osztályok megszünésének problémájára hívták fel a figyelmet. Újvidéken négy iskolában volt lehetőség magyar nyelven tanulni, viszont ez változóban van, hiszen a gyermekek létszámának általános csökkenése miatt egyre kevesebb magyar nyelvü tagozatot tudnak „feltölteni” kisdiákokkal. Egy pedagógus kifejti, hogy ha egy év „kimarad”, tehát ha egyik évben nem indul magyar nyelvű tagozat egy iskolában, akkor az azt követő évben már egyre nehezebb diákokat toborozni, és ez a folyamat lassan az magyar nyelvü tagozat sorvadásához, megszünéséhez vezet.

„Általános iskolából, négyben müködik magyar oktatás, a József Attilában, a Petöfi Sándorban, a Sonjában [Sonja Marinković-ban], és a Nikola Tesla-ában, ez a négy. Viszont, ez, mondjam így, ez az adat tavalyig volt nagyjából érvénybe, mert nem nyíltak azt hiszem a Sonjába, nem tudtak új elsösöket toborozni, és a Teslában sem tudtak új elsösökkel osztályt nyitni...egyenlöre lehet még mind a négyben tanulni, az elsö osztályok nem indulnak, ami azt jelenti, hogy mondjam így, hat-hét-nyolcéven belül ott megszünnek. Ott a lényeg, hogy ha nem indulnak az elsö osztályok, egy év kimarad, akkor a következö évben már nehezebb összeszedni annyi gyereket, hogy meglehessen nyitni első osztályt, és két-három évig nem nyilik magyar elsö osztály, az azt jelnti, hogy öt év múlva nem lesz magyar nyelvü oktatás abban az iskolában" (interjúrészlet, pedagógus-U1,Újvidék, 2014).

Hasonló helyzetre reflektálva, az újvidéki József Attila Általános Iskola tanárai elmondták, hogy iskolájukban első osztálytól nyolcadik osztályig egy-egy magyar osztály müködik, ahol a gyermeklétszám 10 fó körül mozog. Külön említést tesznek az anyanyelvápolás óráról, ahol hozzáteszik, hogy ezt föleg a vegyes házasságból származó diákok veszik igénybe, illetve azon tanulók, akik rokonságában, környezetében élnek még a magyar nyelvü kapcsolatok. Mindemellett az interjút adó tanárok kiemelik, hogy iskolájukban nemcsak magyar, hanem ruszin, szlovák és roma nyelvápolás órát is tartanak, amelyre igen büszke az iskola.

„... körülbelül 1200 tanulója van az iskolának. Egy-egy magyar osztály van elsötöl nyolcadikig, a tízes létszám az az átlag, tehát van ettöl több és kevesebb is, körülbelül 80 magyar diákunk van. Ezen felül magyar nyelvápoláson, még körülbelül százan vesznek részt. Ez heti két órával megy az iskola keretein belül. Ezek a diákok föként vegyes házasságokból 
jönnek, de vannak olyanok is, akik beíratják, hogy megtanulják a magyar nyelvet, mert a környezetükben, a rokonságban, valahol valamilyen magyar szál müködik. Nálunk egyébként, a magyar nyelvápoláson felül van még ruszin, szlovák, meg roma nyelvápolás" (interjúrészlet, pedagógus-U2, Ujvidék, 2014).

A létszámfogyás problémájával kapcsolatban a pedagógusok úgy értékelték a helyzetet, hogy Újvidék sokkal jobb helyzetben van, mint más vajdasági települések, hiszen igaz, hogy sok magyar nemzetiségü családot érint az elvándorlás, és a környezet miatti természetes asszimiláció jelensége, de ugyanakkor számos család be is költözik Újvidékre, hiszen a település Vajdaság egyik legdinamikusabban fejlödő városa. Az Újvidékre beköltözött, gyermekekkel rendelkező fiatal családok pedig növelik az itt müködő iskolákban tanuló diákok létszámát. Bár a pedagógusok hozzáteszik, hogy az elvándorlást tekintve, főleg a vajdasági magyar tömbterületekröl jellemzőbb, hogy a családok célországa inkább Magyarország.

„,Ujvidéknek van egy nagy elönye, a többi, várossal, faluval ellentétben, hogy Újvidék nö, Ujvidékre beköltöznek az emberek, ugyanúgy, ahogy ide vonzza a szerb ajkúakat, a magyar ajkúakat is egész Vajdaság területéröl. Annyi, hogy a magyar ajkúaknak az északi irányítottsága sokkal erösebb, azon egyszerü okoknál fogva, hogy mégis az anyaország ott van, így aztán nagyon sokan mennek Magyarországra, tölünk is. Most megint volt egy kivándorlási hullám... viszont ugyanúgy be is költöznek Újvidékre magyarok, én se vagyok újvidéki születésü..." (interjúrészlet, pedagógus-U2, Újvidék, 2014).

A zombori tanárok szintén a diákok létszámfogyásáról és a napjainkban egyre intenzívebben megjelenő elvándorlás jelenségéről beszéltek. Egy interjút adó pedagógus elmondta, hogy az osztályában jelenleg három tanuló van, négy volt, de mára az osztálylétszám három diákra zsugorodott, akik magyar nyelven tanulnak. Elmondásuk szerint a jelenlegi osztálylétszámok öt és tíz fö között alakulnak, míg az előző években többen tanultak az osztályokban, a csökkenés egyik fök okát a fokozódó elvándorlásban látja.

„Nekem három tanulóm van. Igen. Négyen voltak, és most már hárman vannak. Az elvándorlás hihetetlen mértékü, úgyhogy nagyon kevesen vannak. Általában heten-nyolcan vannak osztályonként, de most az enyémben éppen hárman vannak, szóval ez a legkisebb tagozat. A hetedikesek vannak heten, a hatodikosok nyolcan, az ötödikesek hatan vannak. Tavaly például tizenketten voltak, aztán elötte megint ilyen nyolcan, akkor kilencen. Akkor talán még inkább a 10 felé húzott, most már az öt és a tíz között van” (interjúrészlet, pedagógus-Z8, Zombor, 2014).

Több pedagógus, aki általános és középfokú intézményekben is oktat, az általános iskolás diákok létszámfogyásának problémája mellett hangsúlyozza, hogy egyes középfokú intézmények magyar nyelvü osztályaiban szintén csökken a tanulók létszáma. Az oktatók elmondták, hogy a középfokú intézményekben, főleg a gimnáziumokban, az előző években általánosak voltak a húszfös osztályok, ezzel ellentétben a jelenlegi diák létszámok öt és tíz fö körül alakulnak egy-egy osztályban. A létszámfogyás oka egyrészt az elvándorlásban keresendő, másrészt a gimnáziumokat az utóbbi időben kevesebben választják. A diákok úgy gondolják, hogy négy év után nincs konkrét ,szakma a kezükben”, mindemellett a gimnázium után tovább kell tanulniuk, ha érvényesülni szeretnének, és emiatt a tanulók kis létszáma választja csak a magyar nyelvü gimnáziumokat. 
„A gimnáziumban négy osztály van, tehát elsőtöl negyedikig, általános irányzat, és az első osztályban van nyolc diák, a másodikban hét, a harmadikban, ahol én osztályfönök vagyok, ott öten vannak, és a negyedikben nyolcan. Úgyhogy, nagyon kevés, de, mondjuk rá, nekem az elözö generációm, akik most harmadéves egyetemisták, 17-en voltak, úgyhogy voltak nagyobb osztályaink is, csak, mondom, most, most valahogy csökken a diákok száma." (interjúrészlet, pedagógus-Z2, Zombor,2014).

Az oktatók a diákok létszámfogyása mellett megemlítik a szakképzett, magyarul is előadni tudó pedagógusok hiányát is. Véleményük szerint azoknak a diákoknak és szüleiknek, akik a magyar általános iskolát követően magyar nyelvü középiskolába, vagy gimnáziumba íratják gyermekeiket, fontos, hogy magyarul jól tudó, szakképzett oktatók tanítsanak. Véleményük szerint egy oktató esetében nem mindegy, hogy hogyan tud magyar nyelven beszélni illetve előadni, itt főleg a szakkifejezések használatára utaltak.

„... sok helyt megcsinálják az iskolát, hogy úgymond magyar osztálynak, de, viszont a magyarul elöadó pedagógusok száma minden évben kevesebb. És különösen azoknak a száma, akik szakképzettek arra, hogy elöadjanak. Na, most, hogy ha nézem a gimnáziumot, ök is nagyon kevés igazán magyarul tanult kádert tudnak elöhozni, hogy az tudjon is magyarul elöadni. Nem mindegy az, hogy tudok magyarul, és tudok magyarul elöadni is. Mert a szakkifejezések, maga a tanmenet, az egésznek egész más azért, hogyha magyarul tanult, magyarul hallotta az elözö elöadásokat, és úgy fogja beállitani azokat az órákat, vagy megcsinálta, megtanulta ö azt, de annak nem, nem úgy hangzik. És ne mondjam azt, hogy nagyon sok tantárgyban van az, hogy egyszerüen nincs szakelöadó, és akarom, nem akarom, szerbül kell tanulnom (interjúrészlet, pedagógus-Z5, Zombor,2014).

\subsection{Az iskola- és tannyelvválasztást befolyásoló szempontok}

Az iskola megválasztásakor a nagykikindai, az újvidéki és a zombori szülők számára az egyik legfontosabb szempont az iskola közelsége volt, e szempontot a tanító/tanítónő jó hírneve, illetve az iskola jó hírneve követte. Szintén fontos tényező volt az, hogy a szülő vagy a nagyszülő maga is ugyanabban az iskolában végezte tanulmányait, továbbá, hogy a tanuló idősebb testvére is ugyanabban az iskolában tanul/tanult és ez által a szülő már ismeri az ott tanító tanárokat. A kutatás eredményei rámutattak, hogy a legtöbb esetben nem egy, hanem egyszerre több tényező is hatással van a diákok oktatási nyelvének megválasztásában, és ezek egymásra épülnek. Arra a kérdésemre, hogy gyerekek iskoláztatásával kapcsolatban a családon belül ki hozta meg a döntést, a diákok és a szülők nagy többsége az édesanyát jelölte meg, illetve a házastársak közösen döntöttek.

\subsubsection{Iskola közelsége és hírneve}

A pedagógusok egybehangzóan elmondták, hogy az eddigi tapasztalataik alapján az iskola közelsége döntő fontosságú az iskolaválasztás során, hiszen a szülőknek nagyon fontos szempont, hogy gyermekük minél gyorsabban, és minél biztonságosabb útvonalon érjen el az iskolához. Az elmúlt években ez jelentős tényezővé vált, főleg a fiatalabb szülők körében. Ehhez kapcsolódóan a pedagógusok kiemelik, hogy az iskola közelsége mellett, az iskola jó hírneve is szerepet játszik a döntésben, tehát lényeges szempont, hogy a szülőkhöz és diákokhoz milyen információk jutnak el az iskoláról. 
„... az iskola közelsége az fontos, tehát ez Újvidéken igencsak fontos dolog, és az utóbbi idöben egyre nagyobb szerepet kap az, hogy milyen az iskolának a hírneve...” (interjúrészlet, pedagógus-U2, Újvidék, 2014).

Az iskola közelségének szempontján túl, az iskolaválasztás során hasonlóan lényeges faktor, hogy a szülő is ugyanabba az iskolába járt, ahová gyermekét szeretné íratni, illetve további tényező lehet az is, hogy a szülő már ismeri a jövendőbeli tanítót. Ehhez kötődően az iskola szempontjából fontos, hogy jó kapcsolatot ápoljon az óvodákkal, hiszen óvodalátogatásokkor (beiskolázás előtt) a leendő elsős diákok szülei találkozhatnak az iskola tanáraival. Azok az iskolák, ahol magyar nyelvü oktatás is folyik, ezen találkozások alkalmával felhívják a magyar nemzetiségü, és a vegyes házasságban élö szülök figyelmét is, hogy iskolájukban lehetőség van magyar nyelven tanulni.

„Iskolaválasztáskor leginkább az a döntö, hogy a közelben laknak, akkor az is lehet, hogy a szülö ide járt vagy, hogy ismeri a tanitót. Ugye bejárunk mi az óvodákba is, és megismerkedünk a szülökkel már korábban, meg a gyerekekkel is, de azért vannak összejövetelek, amikor a szülöknek mondva lesz, hogy magyar osztályba van lehetöség beíratni a gyereküket." (interjúrészlet, pedagógus-U1, Újvidék, 2014).

Az iskolaválasztás során a szülök döntő többsége az iskola közelségét fontos befolyásoló szempontként jellemezte. Ezen felül egyes szülök azt is figyelembe vették, hogy minél kevesebb közlekedési jármüvet kelljen ahhoz igénybe venni, hogy gyermekük eljuthasson az iskolába. Az idézett interjúrészletben egy édesapa elmondta, hogy abban az iskolában, ahol jelenleg gyermeke tanul, lehetőség volt mindkét nyelven tanulni (magyarszerb), de a szerb nyelvet elönyösebbnek tartották, mivel ez az ország nyelve, de első helyen, a döntési okok között az iskola közelsége állt.

„... azért írattuk be ide a gyereket, mert hozzánk ez volt a legközelebb” (interjúrészlet, szülöU14, Újvidék, 2014).

Több diák szintén az iskola közelségét emelte ki, mint befolyásoló tényezőt, valamint elmondásuk szerint, a család döntésében az a családi tradíció is közrejátszott, miszerint a családtagok (édesanya, nagymama, testvér) szintén ugyanabban az iskolában tanult, így a diákok is követték a családi mintát.

„Azért iratkoztam ebbe az iskolába, mert anyukám és mindkét nagymamám is ebbe az iskolába járt, valamint azért, mert a közelben laktunk...” (interjúrészlet, diák-K6, Nagykikinda, 2013).

„... ugyanebbe az iskolába jártak a testvéreim, mint én, de ők magyar tagozatra jártak. Ök idösebbek, mint én, ök már felnöttek” (interjúrészlet, diák-K9, Nagykikinda, 2013).

\subsubsection{Családi nyelvhasználathoz igazodó iskolaválasztás}

Mindhárom mintaterületen végzett kutatás során a megkérdezett tanulók családjukkal többnyire szerb nyelven beszélnek, és a magyar nyelvet ritkábban vagy inkább nem használják, e miatt a kutatásba bevont szülők nagy része természetesnek tartotta, hogy a gyermeküket szerb osztályba íratták. A megkérdezett szülők elmondták, hogy valójában nem igazán gondolkodtak el az iskola tannyelvén, automatikusan a szerb osztályba íratták a 
gyermekeiket, nem igazán merült fel a magyar nyelven való oktatás kérdése, mindemellett döntésükre kihatással volt a későbbi boldogulás esélye, és a szélesebb körü továbbtanulási lehetőségek is.

„Igazából nem is nagyon gondolkodtunk, de jobbnak láttuk a feleségemmel a szerb osztályt, mert később több középiskola közül bír választani..."(interjúrészlet, szülö-U14, Újvidék, 2014).

Az egyik megkérdezett nagykikindai szülő (édesapa) elmondta, amely több szórványban élö családra is jellemző, hogy azért döntöttek a szerb tannyelü iskoláztatás mellett, mert ö nagyon sokat dolgozott és emiatt nagyon keveset volt otthon, így a gyerekekkel nem nagyon beszélgetett magyarul. Szerb nemzetiségü felesége volt otthon és vigyázott a gyerekekre, aki szerb nyelven beszélt velük, így jobban elsajátították a szerb nyelvet, és ennek következtében később a gyerekeket szerb tannyelvü iskolába íratták. Ebben az esetben érvényesül Árendás Zsuzsanna munkájában vizsgált kérdés, miszerint az iskolaválasztást a társadalmi nemmel (gender) hozza összefüggésbe, miszerint az otthoni korrepetáció és lecketanulás az anya feladata, és ez összefüggésben áll a oktatási nyelv megválasztásával (ÁRENDÁs Zs. 2012).

én nagyon sokat dolgozok, keveset vagyok itthon a gyerekekkel. A feleségem csak szerbül tud, ö van jobban a gyerekekkel itthon, és így a gyerekek jobban megtanultak szerbül. Ha magyar osztályba mentek volna, én nem is tudtam volna nekik segíteni a tanulásban, mert nem vagyok itthon, és a feleségem, ahogy mondtam, nem tud magyarul, ezért így láttuk jobbnak, ha a gyerekeket szerb osztályba íratjuk...” (interjúrészlet, szülö-K11, Nagykikinda, 2013).

\subsubsection{Későbbi érvényesülés/boldogulás esélye}

Az oktatással kapcsolatos egyéni döntéseket meghatározó mértékben a későbbi munkaerö-piaci esélyek befolyásolták, vagyis a szülők nagy része a későbbi érvényesülésre gondolva íratta gyermekét többségi nyelvü osztályba. Arra a kérdésünkre, hogy általában a magyar szülők miért íratják szerb tagozatra gyermekeiket, egyik nagykikindai pedagógustól, azt a választ kaptuk, hogy a szülők úgy érzik, hogy ha itt, Szerbiában élnek, akkor inkább szerb osztályba íratják be a gyereküket, főleg a későbbi érvényesülésre gondolva. A pedagógus hozzátette, hogy ő már több szülőtől azt hallotta, amely véleménye szerint, egyes szülőknél döntő a gyermekük tannyelvválasztása során, hogy a szülőnek a magyar tannyelvü általános iskola után nehéz volt a középiskolában szerb nyelven tanulni, és később a szerb nyelv hiányos tudása miatt nem mertek egyetemen tanulni sem. Ennek okaként a szülők úgy gondolják, hogy jobb, ha gyermekük már az általános iskolában szembesül ezzel, és a későbbiekben vélhetően könnyebben tud majd érvényesülni. A szerb tagozat választásánál közrejátszik még az a tényező is, hogy a szülők idejében, Jugoszláviában, az volt a jellemző nézet, hogy beszélj úgy, ahogy mindenki megérti, és ez a nyelv abban az időben ${ }^{63}$ a szerb volt.

A megkérdezett pedagógusok többsége úgy gondolja, hogy a döntés nem egyszerü, több tényező is szerepet játszik. Az egyik gyakran előforduló ok, hogy a szülők a későbbi

63 „Testvériség - Egység időszaka” 
munkaerö-piaci érvénysülést szem elött tartva tekintik elönyösebbnek az államnyelven történő iskoláztatást.

„... ha a gyerek jól megtanul szerbül és itt marad, akkor majd érvényesülni tud...” (interjúrészlet, szülö-U12, Újvidék, 2014).

„... mert akkor már biztosak voltunk benne, hogy szerbül fog menni, mert nagyobb a választéka [tovább tanulást és munkaerö-piaci szempontokat figyelembe véve] neki..." (interjúrészlet, szülö-Z15, Zombor, 2014).

A családokat arról is kérdeztem, hogy hallottak-e az oktatási- és nevelési támogatásról, és ez hogyan befolyásolja az iskolaválasztást, esetleg a gyermek jövőbeli iskolai útját. A szülők többségében hallottak és tudnak a támogatásról, egyrészt jónak tartják, hiszen minden támogatás jól jön a családoknak, viszont ennek ellenére elönyösebbnek látták gyermekük részére a szerb nyelvü oktatást, amely a későbbi érvényesüléssel hozható összefüggésbe. Mindemellett egy édesapa elmondta, hogy a meggyőződését nem szerette volna ahhoz kötni, hogy könnyebb lenne gyermekét kiiskoláztatni.

„amennyi mindent áll a magyar állam, ez a szülöföldön magyarul opcióban, tudok én erröl az egészröl, de a meggyözödéseimet nem akarom ahhoz kötni, hogy könnyebb lenne kiiskoláztatni a gyereket. Mert, ha befejez itt egy középiskolát magyarul, de itt egyetem, ne beszéljünk mellé, de az mindig kisebb esély, hogy legyen. Tudna menni utána szerbül, de feleségem is megszenvedett ezzel, hogy ö magyar után ment szerbül. Nem egyszerü egyikröl váltani a másikra” (interjúrészlet, szülö-U13, Újvidék, 2014).

Mindhárom településen a szülőkkel való interjú során felvetődött a szülők részéről az a meglátás, hogy miután gyermekeik elkezdték tanulmányaikat az első osztályban szerb nyelven, ott döbbentek rá, hogy ők maguk talán nem is tudnak olyan jól szerbül, annak ellenére, hogy szinte csak szerb nyelven beszélnek, főleg a munkahelyükön. Ennek oka, saját meglátásuk szerint az, hogy hiányzik az a fajta tudás, amelyet az iskolában töltött évek alatt sajátít el az ember. Mivel a kutatásba bevont szülők egy része magyar nyelven végezte el iskoláit, így gyermekük részére a tanulásban való segítségnyújtás nehézkes volt. Véleményük szerint, azonban ezt a fajta nehézséget kárpótolja az, hogy a későbbiekben gyermekeik könnyebben fognak boldogulni.

„... én is azt hittem, hogy tudok szerbül, és mikor a fiam megindult elsöbe, akkor jöttem rá, hogy mennyire nem tudok szerbül, mert én is ugye, a konyhai nyelvet beszélem, hiányzik az a fajta tudás. A nyelvtant az életbe nem tanulom meg rendesen, nem is érdekel, a magyar nyelvtant se szerettem. Ez miatt szeretném, ha jobban boldogulna, és, hogy itt boldogulna. Könnyebb legyen neki érvényesülni, opciókat választani" (interjúrészlet, szülö-U13, Újvidék, 2014)

A szülők egybehangzó véleménye szerint nagyon fontos az államnyelv ismerete, hiszen ennek hiányában nehezebb a boldogulás, főleg a munkaerőpiacon. A szülők kitértek arra is, hogy az oktatás terén a Szerbiában élö kisebbségeknek joguk van választani, hogy középiskoláig, sőt az egyetemig szerb nyelven, vagy saját anyanyelvükön kívánnak-e tanulni. Véleményük szerint figyelemre méltó, hogy kisebbségeknek van választásuk a tanulási nyelvet illetően, tehát meglátásuk szerint korrekt jogokkal rendelkeznek a kisebbségi oktatás terén. 
„... történelmi határok ide vagy oda, amelyik országban vagy, annak az országnak a nyelvét beszéled. A kisebbségeknek a környezetünkben sehol senkinek sincsen ekkora joga és nem is gyakorolhat ekkora jogot, mi még mindig bírunk választani, hogy akarunk-e magyarul tanulni középiskoláig, az egyetem az már kérdés, persze, és nemcsak a magyarok bírnak választani. Persze, mindig lehet több" (interjúrészlet, szülö-U13, Ujvidék, 2014)

Ehhez kapcsolódóan egy zombori apuka, aki szintén a jobb érvényesülés reményében választotta gyermekének a szerb nyelvü tagozatot, szintén nagyon fontosnak tartja az államnyelv anyanyelvi szintü elsajátítását. A szülö azzal érvelt, hogy baráti körükben sokan kimentek külföldre dolgozni, és ott mindenki gyermekét német nyelven iskoláztatja, vagyis az állam nyelvén.

„Ha kimész külföldre dolgozni mint kisebbség, akkor is tudnod kell az állam nyelvét. Mindenki németül járatja a gyerekét iskolába, óvodába" (interjúrészlet, szülö-Z10, Zombor, 2014).

A tanárok a beiskolázás során sok szülővel találkoznak és beszélgetnek, ezért tapasztalatik alapján, úgy vélik, hogy a szerb nyelvü környezet hatására a szülők, úgy gondolják, hogy gyermekük jobban tud majd érvényesülni, ha szerb tannyelvü iskolában tanul, hiszen így „tökéletesen” elsajátítja majd az államnyelvet, ami majd a későbbiekben az elönyére válhat.

„... föleg a környezet miatt, úgy gondolják, hogy jobban érvényesülnek, ha szerb osztályba mennek" (interjúrészlet, pedagógus-U2, Újvidék, 2014).

\subsubsection{A szülői segítségnyújtás a tanulásban}

Az újvidéki kutatás során új érvként jelentkezett az, hogy a szülő azért döntött a szerb tannyelvü osztály mellett, mert attól félt, hogy gyermekének a magyarul történő tanulás során nem tud majd segíteni. Itt a pedagógusok is megemlítették, hogy a legtöbb magyar nemzetiségü szülő az általános iskolát leszámítva szerb nyelven végezte iskoláit, jelenleg munkahelyükön is szerb nyelven beszélnek, és ök már attól tartanak, hogy gyermekeiknek magyar nyelven nem tudnak majd segíteni a tanulásban.

A pedagógusok által adott interjúkban került szóba az az eset is, amikor egy magyar nemzetiségü család gyermekét szerb nyelvü iskolába íratta, viszont a kisfiú nem tudott beilleszkedni, ezért a szülők átíratták magyar osztályba. Viszont problémaként jelentkezett, hogy mindkét szülő az iskoláit szerb nyelven végezte, ezért nem tudtak gyermeküknek segíteni a magyar nyelven való tanulásban, ezért magántanárt fogadtak gyermekük mellé. Az interjú során a szóban forgó pedagógus érdekes jelenségre hívta fel a figyelmet, ugyanis arról beszélt, hogy esetenként több olyan diák jár magyar tannyelvü iskolákban, akik otthon, családi környezetben szerbül beszélnek, és számukra nehézséget jelent a magyar nyelvü irodalmi szövegek megértése, és a magyar nyelvü fogalmazások megírása, hiszen ezek a diákok „szerbül gondolkodnak”. Ilyen esetekben a magyar nyelvet tanító pedagógusok is nehéz helyzetben vannak, állítja az interjút adó tanítónő, hiszen nem adhat egyes-kettest ezeknek a tanulóknak, hiszen elvennék a kedvét a diákoknak, és a szülöknek is egyaránt, vagy adjon a tanár mindenkinek ötöst „,csak azért mert szegény szülö magyarra adta a gyerekét?”.

„Az iskolából az egyik kisfiút beíratták szerb osztályba, de nem tudott oda beilleszkedni, akkor a szülö beíratta magyar iskolába, de már nehéz a gyereknek, már külön tanítónö jár hozzá, privát, mert nem tudják tartani a szülök a frontot, mert már nem tudja követni, nem 
tudnak neki segíteni. Az apuka mérnök, végig az iskoláit szerbül járta, otthon szerbül beszélnek, de a kislányukat már szintén szerb iskolába íratták. De ez nem is olyan rossz, mint amilyennek látszik, képzeld el milyen rossz helyzetben vannak a magyar tanárok, mikor a magyar nyelvet tanítják öttöl nyolcadikig és tényleg a haja égnek áll, hogy hová is rakja a kritériumot, mert ugye, hogy várod el, hogy fogalmazást írjon és, hogy értelmezzen irodalmi szövegeket, irodalmi nyelvet használva, de nem tudod ezt elvárni, mert haza megy és a szülővel szerbül beszél, és amott magyar iskolába jár. Na most itt kell nagyon óvatosnak lenni, ugye beszélik rá a gyerekeket, hogy magyar iskolába menjenek minden áron, de itt van ez a kettöség. És azt is kell nézni, hogy a tanárok és valójában az iskolarendszer ne vegye el a reményt a szegény szülöktöl, meg a szegény gyerekektöl, hogy magyarból mindenkinek egyese, meg kettese van/lenne magyarból, ha a tanár tartja a kritériumot, szóval nehéz a helyzet. Vannak gyerekek magyar osztályokban is, akik nem beszélnek rendesen magyarul, nem is értik az irodalmi szövegrészleteket, nem tudja megérteni, nem tud abban a világban gondolkodni, szerbül gondolkodik, azt a gondolkodási rendszert használja. Nagyon nehéz ez, mert szegény tanár mit csináljon, vagy mindenkinek adjon ötöst, csak azért mert szegény szülö magyarra adta a gyerekét, és a tanár mégis hármast ad neki, ez szégyen lenne, mit szólnának, szóval sok hátulütöje van ennek." (interjúrészlet, pedagógus-U3, Úvidék, 2014).

A szülök egy kisebb része azt nyilatkozta, hogy általánosságban véve automatikusan döntöttek a szerb osztály mellet, de döntéshozatalukban az a félelmük is közre játszott, hogy ha magyar osztályba íratnák gyermekeiket, akkor nem tudnának segítséget nyújtani a tanulásban, mivel saját bevallásuk szerint már ők maguk sem beszélik olyan jól a magyar nyelvet.

„Itt nálunk erös a szerb vonal, a szülök nem akarnak bibelödni a magyarral. Mi se beszélünk már olyan jól, nem is tudtam volna segíteni a lányomnak, nem lett volna senki, aki itthon tanul vele" (interjúrészlet, szülö-U14, Újvidék, 2014).

\subsubsection{A szülők saját negatív/pozitív tapasztalata}

Azok a tapasztalatok és élmények, amelyet a szülő saját iskoláztatása során szerzett, legtöbb esetben meghatározzák a gyermek iskolájának megválasztását is. Az elemzés során egy édesanya véleményét emeltem ki, amely jól tükrözi, hogy a szülö saját negatív tapasztalata milyen nagy szerepet játszik gyermeke iskolai életútjában. A szóban forgó szülö, aki általános és a középiskolát magyar nyelven végezte, arról a döntéséről mesélt, hogy melyek voltak azok az okok és szempontok, amelynek következtében jobbnak látta gyermeke részére a szerb nyelvü tagozatot. A szülő nem Újvidéken nevelkedett, később költöztek csak a városba. Az édesanya felidézi, hogy már régebben eldöntötte, hogy ha egyszer gyermekei lesznek és Szerbiában fognak élni, akkor kizárólag szerb nyelven fogja iskoláztatni őket. Ebben a döntésében két ok játszott szerepet. Az egyik ok saját életútja volt, ugyanis egyetemi évei alatt a szerb nyelv megnehezítette iskolai előmenetelét, és ezt a fajta nehézséget szerette volna fia számára megkönnyíteni, oly módón, hogy az általános iskolától kezdve fia szerb nyelvi környezetben tanul. A másik okként testvére szerb nyelvü középiskolai életútját hozta fel példaként, amely véleménye szerint, nagyban hozzájárult öccse később kialakult sikeres karrierjéhez.

„... nekem már úgy volt régen is, hogy ha lesznek gyerekeim, akkor magyar nyelven, ha csak lehet, nem fogom adni a gyereket, és, hogy ha maradunk Szerbiában. Tehát nekem az elsö ok én voltam, hogy az egészet így átéltem [egyetemi évek nehézségei], hogy magyar nyelven, és utána a választék nem volt akkora, vagy olyasmit kellett volna választanom, amit nem 
szeretek, hogy magyarul tudjak tanulni, vagy pedig olyat, ugye, amit szeretek, viszont azt csak szerbül, és akkor így automatikusan megduplázódott a nehézség. A második tény az öcsém. Ö magyarul fejezte az elemit, viszont ö már középbe szerbül járt. Mikor ö került oda, hogy iskolát kellett választani, mi legyen, majd ő megpróbálja szerbül. Az iskolába ö tanult szerbet, meg az utcán is annyit, amennyit, tehát az utcai nyelvet tudta, de a szakszavak ott is hiányoztak. Úgyhogy az elsö osztályt kemény kettes, hármasokkal fejezte a nyelv miatt, elsödlegesen a nyelv miatt, de befejezte. Ahogy az évek múltak erösödött, meg ugye megtanulta a nyelvet nagyon jól... Tehát én ezeket a szempontokat vettem elsödlegesen figyelembe, hogy az én gyerekemnek ne csináljam azt, hogy az iskolaválasztás elött azon kelljen gondolkozni, hogy ö mit szeret, de mivel azt nem birja, mert nem tudja a nyelvet eléggé, és akkor mit bír, vagy mit lehet” (interjúrészlet, szülö-U12, Újvidék, 2014).

Az édesanya kiemeli, hogy a gimnáziumi tanulmányai után, csak szerb nyelven tudta folytatni tanulmányait, vagy olyan egyetemet/föiskolát kellett volna választania, ami magyar nyelven is elérhető lett volna, viszont akkor olyan szakon kellett volna tanulnia, ami valójában nem érdekelte, és ez számára komoly dilemmát jelentett. Végül szerb nyelven kezdte meg egyetemi tanulmányait, mely véleménye szerint a hiányos szerb nyelvtudása miatt, „dupla olyan nehézségü volt”, mintha magyarul tanult volna. A szülő saját elmondása szerint jól beszél szerb nyelven, hiszen szerb nemzetiségü felmenőkkel is rendelkezett, de ennek ellenére nyelvtudása nem bizonyult elégségesnek. Kiemeli, hogy egyetemi évei alatt sokat szenvedet és ezt szerette volna elkerülni fia tekintetében. Ebben az esetben jól látszik, hogy az édesanya nem elégedett saját magyar nyelvű iskolai életútjával, ezért „fordított” a helyzeten, és gyermekét szerb nyelven iskoláztatja.

„Magyar az anyanyelvem, a szerb az mellette, most nem mondanám, hogy anyanyelvi szinten, de jó beszélem, jobban, mint azelött, németet azt középfokon beszélem, angolt többet értem, mint amit beszélek. Én mint gyerek, úgy nöttem fel, hogy nekünk normális volt, hogy fél órát magyarul, fél órát szerbül, vagy éppen ki hogy tudta kifejezni magát. Én gyerekkorom óta beszélem a szerbet, és ez nekem normális is volt, nem volt vele gondom, habár nem tudtam kitünöen szerbül, söt miután kimentünk a magyarokhoz és utána hazajöttünk, sokat felejtettem...tehát az elemit, meg a középiskolát magyarul végeztem, és akkor az egyetemre indultam szerb nyelven, mivel magyarul csak a magyar tanszék volt, és ott utána megláttam, hogy mennyire is fontos, hogy az iskolában, ugye a [szerb]nyelvet megtanuljuk, mert Szerbiában lakunk, hogy azért azt tudni kell, meg forszírozhatták volna jobban is. Úgy elemibe, meg középbe, olyan tanáraim voltak, akik nem voltak éppen annyira oda, hogy most a gyerekeknek fontos legyen megtanitani a [szerb] nyelvet, és mivel szerbül volt az elöadás, vagy németül, ez nem lett volna olyan probléma, de mivel én a némettel még nem álltam olyan szinten, hogy én mindent németül mondjak, ezért én inkább a szerbet választottam, de hát ugye a szakszavak meg satöbbi, akkor hazamentem, és akkor szerbröl forditottam magyarra, hogy megértsem, hogy mit kell, hogy megtanuljak, hát nehéz volt, és erre sok idöm elment" (interjúrészlet, szülö-U12, Újvidék, 2014).

Egy másik szülő, aki Temerinben nevelkedett, de jelenleg Újvidéken él családjával, szintén arról számolt be, hogy egyrészt saját negatív iskolai tapasztalatai alapján döntött úgy, hogy gyermeke részére a szerb tannyelü oktatást választja, ezzel szeretné megkönnyíteni gyermeke részére a későbbi érvényesülését. A szülő hangsúlyozza, hogy amikor középiskolát választott magának nem érdeklődési körének megfelelően döntött, hanem az a tényező játszott szerepet, hogy mely szakokon adott a lehetőség a magyar nyelvü tanulásra. Saját elmondása 
szerint, akkoriban azon a véleményen volt, hogy azért nyitnak magyar nyelvü tagozatokat, hogy a magyar gyerekek oda iratkozzanak és anyanyelvükön tanuljanak. Ma már ezt a döntését megbánta, jelenlegi véleménye szerint olyan szakmát választana, ami érdekli, és nem a tanítás nyelve alapján választana. Mindemellett az interjút adó édesapa arról is beszélt, hogy látta saját nővérét, aki szerb nyelven tanult középiskolában, és számára ez igen nehéz volt. Ezen okoknál fogva jobbnak látta, ha gyermekét általános iskolától kezdve szerb nyelven taníttatja.

„Az iskolámat, azt egyrészt azért választottam, amit választottam, mert magyarul akartam menni, bár ezt már manapság hibának találom. Ez hiba, mert tulajdonképpen azt kellett volna választani, amit az ember úgymond szeret... mondjuk tölem sokkal rosszabbul beszélök elmentek szerb nyelven, de én nem akartam. Szóval azért nyitnak magyar tagozatot, hogy oda magyar gyerekek menjenek, ilyen felfogással voltam, utána elmentem egy olyan osztályba, ahol nem azt mondom, hogy kidobtam a három évemet, de majdnem. Nem akartam menni szerbül középiskolába, a másik, láttam, hogy a testvérem szerbül ment középiskolába, ö megizzadt vele rendesen, ö megizzadt a szerbbel, ö megizzadt a hozzáállással, 90-es évek, rengeteg menekült..." (interjúrészlet, szülö-U13, Újvidék, 2014).

\subsection{Az óvodai/bölcsődei nevelés befolyásoló hatása}

A megkérdezett gyerekek mindegyike szerb nyelvű óvodába járt, így a szülők már azt tartották helyesnek, hogy ha gyermeküket szerb tannyelvü osztályba íratják. Az óvoda megválasztásnál szintén a távolság, a földrajzi elhelyezkedés volt a meghatározó szempont. A pedagógusok is megerősítették, hogy az iskolában tanuló gyerekek 95 százaléka járt óvodába, legalább két évet.

Azokban a családokban, ahol mindkét szülő dolgozik és nincs, aki vigyázzon a gyerekekre, a szülők kénytelenek a bölcsőde mellett dönteni. Az egyik nagykikindai pedagógus kiemelte, hogy valójában már itt kezdődnek a problémák, ugyanis Nagykikindán nincs magyar bölcsőde, és a szerb bölcsődékben ,elvesznek” a magyar gyerekek. Itt hangsúlyozni kell, hogy a kutatást követően 2017-ben Kárpát-medencei szintü óvodafejlesztési program indult el, melynek köszönhetően Nagykikindán egész napos benntartózkodást lehető tevő magyar tagozatos napközis csoport indult, amelyre korábban nem volt lehetőség. E projekt elsődleges célja, hogy növeljék a magyar óvodások létszámát, és ebböl következően a magyar kisiskolások számát is szeretnénk megemelni. Az óvodafejlesztési program keretein belül Vajdaságban óvodai szórványközpontok létesültek Nagykikindán, Maradékon, Nagybecskereken, Székelykevén, Ürményházán és Zomborban.

a bölcsödében egy-két éves koruktól kezdve járnak a gyerekek és ezáltal megtanulnak szerbül, hiszen szerbül foglalkoznak velük, szerbül tanulnak, szerbül beszélnek. A szülök ráhagyják. Itt már elvesznek a gyerekek, mert ebböl kifolyólag utána már szerb óvodába kerülnek, és innen már szerb nyelvü általános iskolába iratkoznak..." (interjúrészlet, pedagógus-K3, Nagykikinda, 2013).

„Azért döntöttünk ezek az óvodák mellett, mert mind kettö nagyon közel van, meg ez a reon [terület], ahol mi lakunk, ehhez a két óvodához tartozik. Nekünk ezek voltak a legközelebbi óvodák” (interjúrészlet, pedagógus-K10, Nagykikinda, 2013).

„... söt már az óvodába is szerb nyelven járnak a gyerekek. Mi, amikor a lányt beadtuk a napközibe, mert ő négy évet járt napközibe és két évet járt óvodába, és mindjárt a 
kiscsoportba és a nagycsoportba is szerb nyelven járt, és az iskolába mikor beírattuk, már a tesztet is szerbül írta, tehát szerb gyereknek számított..." (interjúrészlet, hatodik osztályos diák nagymamája-K14, Nagykikinda, 2013)

Újvidéken olyan magyar óvodai csoportok alakultak ki, melyek bár papíron csak magyar nyelvűek, a valóságban vegyes vagy inkább szerb nyelven müködnek, mivel a beíratott gyermekek jelentős része nem beszél magyarul, és ehhez idomul a pedagógusok nyelvhasználata is. A szerb nyelvü csoportok telítettsége miatt választják a szülők a magyar nyelvü csoportot. E folyamat hatására ezekben az intézményekben jellemző, hogy egyfelöl, ezekben a csoportokban az iskoláskor elérésére a magyar gyerekek tökéletesen megtanulnak szerbül, másfelől ezek a magyar gyerekek „némelyike” aztán szerb csoporttársaik beiskolázási mintáját követve jellemzően szerb tannyelvü iskolába kerül.

„Magyar nyelvü óvoda van, nem tudom hány van, de van, vannak magyar nyelvü csoportok, viszont az is jellemzö, hogy a magyar nyelvü csoportokban van jócskán szerb nyelvü gyerek, mivel, hogy, nincs elég hely az óvodákban, és a tiszta szerb ajkú szülök is hajlamosak magyar nyelvre beadni a gyerekeket, csak, hogy bekerüljön az óvodába. Szülök, úgy vannak bele, jól van, majd megtanul a gyerek pár szót magyarul, nem lesz semmi baja. Nem igazán csinálnak ebböl problémát, de tudva levö, hogy elég sok szerb nyelvü gyerek van magyar óvodai csoportba, csak annál az oknál fogva, hogy nincs elég hely az óvodába. Itt külön harc folyik az óvodai helyért. Mondjuk, itt nehéz lenne, hogy gyereket szerb csoportba add be, csak azért, hogy esetleg jobban ragadjon rá valami [szerb nyelvtudás], ${ }^{64}$ ez esélytelen. Hosszú várólista van. Ilyen szempontból nincs gond a magyar gyerekekkel, mert van hely nekik, az iskolában és az óvodában is. Egyedül bölcsöde nincs” (interjúrészlet, pedagógus-U1, Újvidék, 2014).

A következő interjúrészletet azért tartom fontosnak kiemelni, mert annak ellenére, hogy egy pedagógus saját 30-40 évvel ezelötti történetét mesélte el, ez a történet a mai napig jellemző és releváns egy szórványnak számító településen. Hiszen több szülő főleg az óvoda közelsége miatt szerb nyelvü óvodába íratja gyermekét. A pedagógusok véleménye szerint a nyelv miatti váltás a gyermekekben egyfajta törést eredményezhet, viszont van, aki ezzel az óvodában, van aki az iskolában, van aki a középiskolában, és van aki az egyetemen szembesül. Kiemelik viszont, hogy ezt a fajta „nyelvi törést”, át lehet/kell hidalni.

„Zomborban születtem, és itt jártam szerb nyelvü óvodába, mivel hogy az közelebb volt. Tehát Zomborban csak egy magyar nyelvü óvoda van, az a város túlsó felén van, mi meg az ellentétében, tehát a másik felében lakunk, úgyhogy szerb nyelvü óvodába írattak, hát de inkább nem mesélek arról mert az nagyon-nagyon kellemetlen volt, hogy nem tudtam megértetni magam, meg nem tudtam érvényesíteni magam. Viszont az óvoda után akkor az iskolában jobban jártam a szerb nyelvvel, mint ahogy tanulták a gyerekek, mert akkor én azt már mind tudtam. Utána elönyöm volt a szerb órákon, ugye az óvoda miatt. Tehát valahol ezt a törést valahogy át kell hidalni az embereknek, valaki az oviban szenvedi meg, valaki az iskolában, valaki a középiskolában. Tehát magyar nyelvü általános iskolában, magyar nyelvü

\footnotetext{
${ }^{64} \mathrm{Az}$ interjúalany itt arra utal, hogy a többségében magyarok által lakott településeken jellemező, hogy egyes magyar nemzetiségű szülök szerb nyelvü óvodába íratják gyermekeiket, hogy szerb nyelvtudásuk fejlődjön, majd ezt követően iskoláztatásuk magyar nyelven folytatódik tovább
} 
középiskolában jártam, és innen mentem Ujvidékre, a szerb egyetemre." (interjúrészlet, pedagógus-Z3, Zombor, 2014).

\subsection{A beilleszkedés nehézségei}

Egy Újvidéken élő édesanya arról beszélt, hogy gyermekének, aki szerb tannyelvü osztályban tanult, nehéz volt az iskolakezdés, kívülállónak érezte magát és emiatt a gyermek magyar osztályba szeretett volna átiratkozni, tehát oktatási nyelvet szeretett volna váltani. A pedagógus és a pszichológus tanácsára, viszont nem történt meg a váltás. Mivel a szülök mindketten magyar nyelvű iskolába jártak, úgy érezték, hogy gyermeküknek nem tudnak megfelelően segíteni, ezért gyermekük mellé magántanárt fogadtak. Végül a kezdeti nehézségeket sikerült áthidalni, viszont a gyermek tanulási problémákkal küzd jelenleg is.

„Erröl beszélgettem a tanitó nénivel, hogy hogy halad a gyerek, hogy ö mit mond generálisan, mert úgy voltunk, mikor a gyerek azt mondta, hogy magyar osztályba akar menni, nem is tudtuk, hogy csináljuk, avval volt a gond, hogy kívülállónak érezte magát. Ö volt magyar, meg még egy kisfiú, ö is jobban tudott magyarul, meg a fiam is, és egymás közt, ök mindig magyarul beszéltek, míg a tanító néni rájuk nem szólt, mert szerb osztály, akkor szerbül. De a kisfiút átíratták másik iskolába, neki ez egy nehéz időszak volt. Tudtuk, hogy nehéz lesz. Megkérdeztem, hogy mi legyen, meg idöközben pszichológussal is beszéltünk. A tanitó nénivel, a másikkal [magán tanitó] megkérdeztem, hogy ö szerinte mi legyen, akkor azt mondta, hogy ha elkezdtük így, muszáj így befejezni, mert a gyereknek konfliktusai lesznek, meg satöbbi. A tanító néni is azt mondta csináljuk végig. A másik meg azt mondta, hogy intelligens, az, hogy a két nyelv, neki ez az elsödleges nehézség... Nehéz neki is, én tisztába vagyok vele, nehéz nekünk is" (interjúrészlet, szülö-U12, Újvidék, 2014).

A szóban forgó családnak van még egy óvodás korú kislánya. Az édesanyát arról kérdeztem, hogy az idősebb gyermek nehézségeit figyelembe véve, a fiatalabb gyermeküket milyen nyelven szeretnék majd iskoláztatni. A szülő egyértelmü válasza az volt, hogy szerb nyelven szeretné iskoláztatni lányukat is, hiszen nem szeretnének különbséget tenni a két gyermek iskoláztatása között, annak ellenére, hogy lányuk jobban beszél magyar nyelven, sőt a testvérek egymás között is magyarul beszélnek.

„... viszont a lánnyal már nem csinálhatjuk azt, hogy ôt magyarul adjuk, pedig ö sokkal szebben beszél magyarul, mint szerbül. A lány valahogy 'huzavonáskodik' egy kicsit a szerbbel, nem tudom miért (interjúrészlet, szülö-U12, Újvidék, 2014).

\subsection{Pedagógusok véleménye a tannyelvválasztásról}

Mindhárom településen a pedagógusok igen segítőkészek voltak, ezért a kutatásban résztvevők többségét ők alkották, emiatt dolgozatomban hangsúlyosan megjelenik a pedagógusok véleménye, hiszen egyrészt az oktatás kulcsszereplői, másodsorban az oktatás és iskoláztatás tekintetében jelentős információval rendelkeznek. A kutatás során, mindhárom településen egybehangzóan kiderült az a négy érv, melynek következtében a magyar identitáshoz köthető szülők a szerb nyelvü oktatást választották, ezért is jelent sokat a pedagógusok véleménye, akik amellett, hogy további tényekkel egészítették ki a szülők által elmondottakat, saját életútjukról is részletesen beszéltek, ami további fontos adatokkal 
egészítette ki kutató munkám, továbbá a legtöbb pedagógus maga is szülő volt, így saját gyermeke iskoláztatásáról is beszélt

Általánosságban elmondható, hogy a pedagógusok úgy gondolják, hogy az iskola első négy osztályát legjobb, ha a magyarul tudó magyar nemzetiségü diák magyar nyelven végzi, hiszen akkor alakul ki az alap szókincse, viszont hangsúlyozzák, hogy az átmenet során, tehát amikor a gyermek iskolát, és ezzel együtt nyelvet vált (általános iskolából középiskolába, vagy középiskolából egyetemre) ez a diák számára egyfajta törést okozhat, de ezt a nehézséget át kell hidalni.

„Hát tudod, ha te magyar vagy, akkor legjobb az általános iskola első négy osztályát mindenféleképpen magyarul, mert akkor fejlödnek ki ezek az alapfogalmak a dolgokról, és az, hogyha ha magyarul marad meg benne, akkor úgy fog gondolkodni, az a gyerek, szerintem. De viszont az átmenet, az mindegy mikor csinálod, ha ötödikbe csinálod, akkor is nagy törés lesz a gyereknek, mert hiába tudsz beszélni, akkor is az anyaggal az elsö pár hónap biztos egy lemaradás, valahogy ki kell, hogy bírjad, vívjad. Vagy ha az a középiskolában, akkor is az ott egy vágás, ha az egyetemen, akkor is, az az egy év, amikor mész át, az az átmenet, az valamikor téged meg fog vágni, úgy az életbe. Nehezebb lesz... Az lenne a legjobb, hogy ha valaki itt van. Én úgy csinálnám, én nem voltam ebben a helyzetben, akkor még nem volt ilyesmi, hogy rögtön már ilyen három éves, négy éves kortól akár tévébe, akár oviba, hogy egy kicsit ilyen is, meg olyan is, több féle nyelvet, hogy egy kicsit szokjon hozzá, akkor talán zökkenömentesebb. De viszont a tanulásban, hiába tudod te a nyelvet beszélni, hogyha a tananyagot, tehát nem jut eszedbe." (interjúrészlet, pedagógus-Z3, Zombor,2014).

Azok a gyerekek, akik magyar nemzetiségüek és családi környezetükben is többet beszélnek magyarul, mint szerbül, de szerb osztályba jártak, azok közül nagyon kevesen vannak olyanok, akik nagyon jó eredménnyel fejezik be az általános iskolát. Általában átlagos eredményeik vannak, tehát közepes vagy még ennél is rosszabb eredménnyel fejezik be az általános iskolát. Több pedagógus kiemelte, hogy nagyon kevés olyan diák volt, aki magyar anyanyelvünek vallotta magát és színkitủnővel vagy kitünővel fejezete volna be az általános iskolát szerb tagozaton. Szerintük azoknak a gyerekeknek, akik magyarul gondolkodnak, nagyon nehéz felzárkózniuk a szerb osztálytársaikhoz a szerb tannyelvü tagozatokon. Azok a gyerekek, akik magyar anyanyelvüek és többnyire magyarul beszélnek otthon, magyarul is gondolkodnak, és ha beíratják őket szerb tannyelvű osztályokba, bizonyos, hogy nem tudnak úgy érvényesülni, ahogyan valószínüsíthetően anyanyelvükön tudnának.

„... Nem hiszek abban, hogy jobb szerb nyelven kezdeni az iskolát egy magyar anyanyelvünek, mert vannak ismeröseim, akik szerb nyelvü általános iskolába jártak, magyarok ök, de mondhatjuk úgy, hogy nem úgy gondolkodnak, és inkább elsöbb szerbül átgondolják a dolgokat, és utána fordítják át magyarra. Ez az én saját véleményem. Nem tudom, hogy melyik a jobb...” (interjúrészlet, pedagógus, Nagykikinda-K2, 2013).

a magyar, az magyarul tanuljon, magyarul beszéljen és magyarul gondolkozzon. Nem arról volt szó, hogy ez egy ilyen nagy nemzetiségi érzés kimutatása, egyszerüen megvannak annak az elönyei. És használjuk ki azokat az elönyöket..."(interjúrészlet, pedagógus-Z5, Zombor,2014).

A szórványban a magyar anyanyelvű diákok már az iskola megkezdése elött jól beszélnek szerb nyelven, van egy alap nyelvtudásuk, amelyre később tudnak építeni az iskolában is. A szórványban élő magyar nemzetiségü gyerekeknek nem kell tartaniuk attól, 
hogy a magyar általános iskolából való „kikerülés” után nem állják meg a helyüket a szerb nyelvü középiskolákban, vagy az egyetemeken, hiszen a környezet miatt ezek a diákok jól beszélik az államnyelvet. Több pedagógus számos olyan diákját hozta fel példának, akik igen jól érvényesültek az egyetemen, és a diploma megszerezése után a munkaerőpiacon is megállták a helyüket.

„... Itt, Kikindán van lehetőség, hogy a gyerekek megtanuljanak szerbül, itt az egész környezet olyan. Nagyon ritka már az is, ha a családban vagy a baráti körben nincs szerb kötödés, nincs valami fonal. A gyerekek egymás között játék közben megtanulnak szerbül. Ez elegendö. Utána már az óvodában általában párhuzamosan vannak szerb és magyar csoportok, tehát már ott is találkoznak a szerb nyelvü gyerekekkel az udvarban és a közös foglalkozáson. Ugyanigy késöbb, amikor általános iskolába kerülnek kettö, majd három és késöbb négy szerb órával szerintem meg lehet tanulni a szerb nyelvet..." (interjúrészlet, pedagógus-K3, Nagykikinda, 2013).

„Nagyon sok olyan diákom volt, aki a magyar elemi után szerb iskolába iratkozott és érvényesültek, söt nagyon is jól, és a szerb egyetemen is megállták a helyüket. A magyar elemi nem kell, hogy akadály legyen, mert a gyerekek már jól beszélnek szerbül... és itt a Telepen is már sokkal több szerb van, és itt is, ha a gyerek kimegy az utcára játszani, itt is szerbül fog beszélni, tehát megtanul szerbül korán, ez nem gond. Még egy nyelvvel gazdagabb lenne annak a szülönek a gyereke, aki magyar osztályba íratná be. Nem beszélve arról, hogy nálunk a szerb nyelvtanulással, magyar osztályokban nyolcadik osztály végére olyan erös, hogy anyanyelvi szinten beszélik" (interjúrészlet, pedagógus-U3, Újvidék,2014).

Mindemellett a pedagógusok szerint a szülőknek sok tényezőt figyelembe kell venniük az iskolába íratáskor. Ezen tényezők egyike a családon belül használt nyelv, a másik pedig a továbbtanulás és az érvényesülés lehetősége. Elmondták, hogy egyes zombori szülök úgy gondolják, hogy ha a külföldön történő taníttatást anyagilag nehezen tudják majd a jövőben biztosítani, emiatt jobb döntésnek gondolják, hogy gyermeküket szerb nyelven taníttassák, ahol „belerázódik a nyelvbe”, és a későbbiekben számukra nem jelent akadályt a nyelvi nehézség.

„... mindenféle tényezö van, szerintem azért, mert gondolják [a szülök], hogy könnyebb lesz. a továbbtanulás. Mert azért sokan most megint itt, meg az anyagiak is beleszólnak, ez a külföldi tanulástól, habár nem is gondoljuk, de tényleg ez az ösztöndíj szisztéma külföldön elég jól müködik, de viszont sok szülö attól fél, hogy anyagilag nem fogja tehát külföldön öket iskoláztatni, akkor már inkább itt, és akkor, ha már itt, akkor viszont a szerb nyelv miatt biztos, hogy, biztos ezek az okok, amiért szerb elemibe is adják... (interjúrészlet,pedagógusZ1, Zombor).

A pedagógusok azon véleményüket is kifejtették, hogy egyes szülök amiatt is választják a szerb nyelvü oktatást, hogy gyermekük ne „lógjon ki” a többségi környezetböl, tehát a környezetnek (szerb nyelvü rokonság, barátok, szomszédok) is igen nagy a befolyásoló hatása.

„Ahol tényleg sok szerb van, és kevés magyar, sokszor van az, hogy a szülök beiratják épp azért, hogy ne ríjon ki a gyerek a környezetböl, stb., úgyhogy ez van. Ez van." (interjúrészlet, pedagógus-Z3, Zombor, 2014).

Egy fiatal magyar nemzetiségü zombori pedagógust arról kérdeztem, hogy ha gyermeke lenne, milyen iskolai stratégiát választana neki, milyen nyelven taníttatná. A 
pedagógus elmondta, hogy véleménye szerint, ha biztos anyagi körülményeket tudna biztosítani, ahhoz, hogy külföldön tanuljon, akkor magyar nyelvü általános iskolába íratná, ha erre nem lenne lehetősége, akkor szerb nyelvü iskolát választana gyermeke részére.

„Most, hogyha lenne gyerekem, és lenne lehetöségem esetleg általános, vagy középiskola után egyetemre járjon Magyarországon, meg másik országokban, akkor, akkor tehát inkább Magyarországra tovább, tehát az általános iskolába, de viszont, hogyha nincs lehetöségem, hogy, hogy valahogy külföldre, akkor, akkor inkább szerbül. Vagy kevert, vagy mind a kettöt. Tehát magyarul, mondjuk, iskolába, tehát általános iskolába, hogy anyanyelvén tanuljon, és akkor még külön még szerbet, hogy azt is megtanulja rendesen. Olyan szinten, hogy késöbb tudjon követni esetleg középiskolai tanítást, vagy egyetemi tanítást szerb nyelven, hogyha éppen magyarul nem tud beiratkozni. Itt, minálunk valamilyen szakra, és nincs lehetöségem, mondjuk, Magyarországra küldeni iskoláztatni. Úgyhogy szerintem fontos mind a kettöt, leg, tehát legalább anyanyelv, tehát anyanyelvi szinten az anyanyelvet, viszont a, a szerbet is, tehát körülbelül, körülbelül megfelelö szinten, tehát nem úgy csak, hogy pár szót, és akkor éppen csakhogy összerakni pár mondatot, hanem elég magas szinten beszélni a szerbet is. Ez mellé lehet, lehetöleg még az angolt is, arra esetleg, arra szükség lehet, meg még plusz a németet is, Európa környékén az, az fontos. Hogy most ezt mennyire lehet kivitelezni, az, az más." (interjúrészlet, pedagógus-Z4, Zombor,2014).

Egy pedagógus arról beszélt, hogy mivel iskoláit szerb nyelven végezte, de a későbbiekben nagy szüksége volt a magyar nyelvre, hiszen e nyelven is tanítania kellett, véleménye szerint az anyanyelv ápolása miatt a magyar nemzetiségü gyerekeknek legalább az általános iskolát érdemes lenne magyar nyelven elvégezniük, így egy nyelvvel „többek” lennének.

„Hát, én most a saját példámból, tehát a saját tapasztalatomból, mivel komplett szerbül fejeztem be az iskolát, és úgy adódott, ugye, az életben, hogy kellett a magyar nyelv, még hogy ha nagyon is, az a véleményem, hogy tehát ilyen, az anyanyelvápolás miatt a, az ilyen nemzeti identitás miatt szerintem legalább az általános iskolát kellene magyarul befejezni..." (interjúrészlet, pedagógus-Z2, Zombor,2014).

A tanárok arról is beszámoltak, hogy véleményük szerint a szülők iskolai végezettsége is befolyásolja a tannyelvválasztást. Szerintük azok a szülők, akik nem rendelkeznek képesítéssel, úgy gondolják, hogy azért vannak hátrányban, mert anyanyelvükön tanultak, ezért jobbnak látják gyermekük részére az államnyelvű oktatást. A pedagógusok kiemelik, hogy tanulmányaik során ők maguk is többször nyelvet váltottak, ezért tudják, hogy ezt a nehézséget át lehet hidalni, így azt gondolják, hogy a magyar anyanyelvü diákok részére kedvező, hogy anyanyelvükön tanulnak az általános iskolában, majd később, ha szükség van rá, középiskolában vagy főiskolán majd nyelvet „váltanak”.

„Én mindenképpen amellett vagyok, hogy ha anyanyelvü környezetben tanulnak meg a diákok elöször legalább alap- és középfokon, hogy ha van lehetöségük rá. Én nyelvet váltottam, elöször németröl magyarra, és aztán magyarról szerbre a tanulmányaim során, és én mindig amellett vagyok, hogy ha van akarata, akkor ez a nyelvváltás könnyü lehet számára, és, hogy nem hátrány anyanyelven tanulni. Viszont föleg azok a szülök, akik nem rendelkeznek képesitéssel, tehát saját maguk is általános iskolai végzettségüek, ők inkább azt mérik fel, hogy ök azért vannak hátrányban vagy hátrányos helyzetben, mert az anyanyelvükön tanultak, és a saját gyerekeiket ezért iratják inkább szerb osztályba, viszont azok a szülök, akik legalább középfokú vagy egyetemi végzettséggel rendelkeznek, azok már sokkal objektívebben 
tudják felmérni ezt a helyzetet, és ök inkább a mellett döntenek, tehát, hogy anyanyelven tanuljanak tovább a gyerekeik. Én ezen a véleményen vagyok." (interjúrészlet, pedagógus-Z8, Zombor,2014).

A interjút adó pedagógusok úgy gondolják, hogy minél több nyelvet tudnak a diákok annál „többet érnek”. Véleményük szerint beszélni kell az államnyelvet, viszont e mellett, ha lehetőség van rá, akkor a magyar anyanyelvü diákok számára kedvezőbb az anyanyelvü oktatás. Viszont kiemelik, hogy több olyan esettel is találkoztak, amely során a magyar anyanyelvü oktatásban tanulók a későbbiekben, olyan szakokon tanulnak tovább, amelyek magyar nyelven elérhetőek, és nem érdeklődési körüknek megfelelően választanak szakmát, vagy egyetemet, pedig nem szabadna megijedni a szerb nyelvtől. Hozzáteszik, hogy ez a jelenség a főleg a magyar többségü településekről származó diákoknál jellemző.

ahány nyelv, annyi ember, mégis csak ebben az országban élünk, tehát Amerikában is a Puerto Rico-i is beszéli az angol nyelvet, hát, egyszerüen itt vagyunk, és nem szívesen mennénk el innen, akkor viszont alkalmazkodni kell. Söt, ezzel több vagy. A munkaeröpiacon is, ha több nyelvet beszélsz, persze, hogy jobban tudsz érvényesülni. De viszont azzal se értek egyet, hogy, hogy a magyar szülök szerb iskolába adják mindjárt elemibe... legalább az elemije, ha anyanyelven, akkor legyen meg... Csak sajnos az van, hogy tényleg a magyar nyelvü diákok az elemiböl akkor úgy választanak szakmát, hogy ami van magyarul. De megint ezt is sajnálom, hogy, mert ezt is nem úgy kéne, tehát nem kéne megijedni a szerb nyelvtöl" (interjúrészlet, pedagógus-Z1, Zombor, 2014)

\subsubsection{Pedagógusok által kiemelt nehézségek}

A pedagógusokkal történt beszélgetések során számos olyan nehézségnek mondható jelenség is felmerült, amelyet úgy vélem e munka keretein belül érdemes megemlíteni. Azok a tanárok, akik maguk is vegyes nemzetiségü családból származnak és iskoláikat szerb nyelven végezték el, arról beszéltek, hogy olykor nehézségeik adódnak a magyar nyelvvel, és beszélnek azokról a problémákról is, amikor egy oktatónak ugyanazon a napon különböző nyelvü osztályokban kell tanítaniuk. Ezen pedagógusok jelenleg is magyar és szerb tannyelvü osztályokban is tanítanak. A különböző nyelven történő oktatásról elmondták, hogy egy napon több alkalommal kell nyelvet váltaniuk, de egy-két éven belül olyan rutinra tettek szert, hogy ma már könnyedén áthidalják ezt a nehézséget.

„... de azért néha észreveszem, hogy pláne az irásban, az ilyen kettös mássalhangzókat, mondjuk rá, nem vagyok biztos benne, hogy mikor kell használni, vagy esetleg az összetett szavak néha nem mennek. Akkor az is egy probléma, mondjuk, a kétnyelvüségnél, hogy ha két nyelven ad elö az ember, hogy vannak olyan napok, amikor, mondjuk, a szerb osztályban beugrik a magyar kifejezés, vagy fordítva, és egy, egy, egy, egy, na, kellemetlen, nem jön be egyszerüen, úgyhogy voltak ilyen érdekes helyzetek, és akkor most attól függ, hogy milyen az osztály. Volt olyan, hogy a szerb osztálynak akkor mondtam, hogy magyarul ezt így mondják, és akkor a gyerekeknek érdekes volt, és azt kaptam vissza, hogy más órákon is kérték, hogy, tanárnö, mondja meg, hogy ezt magyarul hogy mondják. És sokan megjegyeztek ilyen biológiai szakkifejezést, és nem gúnyolták ki, hanem komolyan vették, és akkor, mondjuk rá, visszamondták nekem ezeket a kifejezéseket, akár összefüggtek a tananyaggal, akár nem... de vannak ilyen, ilyen helyzetek, hogy az ember meglepödik, hogy nem utasitsák vissza, meg nem gúnyolják ki, hogy nem jut eszébe a kifejezés." (interjúrészlet, pedagógus-Z2, Zombor,2014). 
„Ez a, ez a, egy olyan dolog, hogy egy-két éven belül megvan a rutin, és akkor már az ember nem is nagyon érzi. Na, hogyha most megtanulsz, mondjuk, egy olyan szinten beszélni egy nyelvet, hogy nem kell állandóan, tehát fordítgatni, tehát, hogy most ezt így mondom magyarul, vagy mondom én ezt másik nyelven, hanem közvetlenül azon a másik nyelven gondolkodsz, akkor már abszolút nem esik nehezedre. Egyszerüen tudod, hogy most szerbül beszélek, és kész. Tehát épp ugyanúgy, mint ahogy beszélsz magyarul, ugyanúgy beszélsz szerbül is, nem gondolkozol azon, hogy most ezt hogy kell mondani, csak ez az, hogy itt, igen, igen, ez pedig csak gyakorlás kérdése. Tehát abban a környezetben, ahol azt a nyelvet beszélik, oda kell elmenni, hallgatni, beszélni az emberekkel, gyakorolni, és elöbb-utóbb azért az a, az a, tudatban megnö az a szint, és akkor már végül is nem is veszed észre, hogy mostan valamikor nehezedre esett a szerb nyelv, vagy nem. Tehát azért, mert egyszerüen be van gyakorolva, épp úgy, mint a kerékpár hajtás is." (interjúrészlet, pedagógus-Z4, Zombor,2014).

A pedagógusok a saját egyetemi éveikről is beszéltek, ami a mai egyetemistákra is igen jellemző, ezért tartom fontosnak ezt kiemelni. Arra emlékeztek vissza, hogy magyar nemzetiségüként az egyetem első évei számukra nehezen indultak, nyelvi nehézségekkel küzdöttek, mert csak hosszú idő után tudták elsajátítani a szakmájuk szaknyelvét szerb nyelven. Arról is említést tesznek, hogy akkoriban több tanár is felajánlotta számukra, hogy magyar nyelven vizsgázhatnak, de mivel szerb nyelven hallgatták óráikat, ezért úgy gondolták számukra talán könnyebb, ha szerb nyelven vizsgáznak.

én tudtam szerbül, de mindig mikor ez a szakterminológia megy, meg egyetemi szinten, úgyhogy az elsó évet, amikor az ember magyarról vált szerb iskolába, akkor bizony-bizony az az elsö év, azt mindig megszenvedi. Azért mert hiába megy a szerb, meg hiába érti azt meg szerbül, de egy dolog megérteni, a másik dolog, mikor neked kell reprodukálni. A mondatokat, a szövegeket, a szakterminológia, tehát az elsö év az nehéz volt, az nagyon nehéz volt, de gondolom nem azért, mert nem tudtam, hanem azért mert kellett eztet a szavakat, mondatokat, kifejezéseket. Amikor megy az ember kolokválni ${ }^{65}$, ott nem bírsz gondolkodni sokat, nem jut eszedbe a szó, hogy mondjuk rá érdekes, hogy kémiából, ugye hát én magyarul jön eszembe, hogy az „O” az oxigén, az „N” az nitrogén, és akkor ott meg az oxigén szerbül „kiseonik”, a nitrogén meg „azot”, és akkor ezt mikor látom, hogy „N”és akkor kell mondani, akkor nitrogén jön eszembe, de közben „azot-ot” kell mondani” (interjúrészlet, pedagógus-Z3, Zombor, 2014).

A tanárok az államnyelv oktatását javító sürgető lépések fontosságára is felhívták a figyelmet. Hangsúlyozták, hogy sürgősen át kellene szervezni a szerb mint nem anyanyelv (környezetnyelv) tantárgy oktatását, mert a jelenlegi program és tankönyv már igencsak elavult, és nehezen lehet a jelenlegi témákkal odafigyelésre ösztönözni az általános és középiskolás diákokat.

„... most meg az a másik, hogy a szerb nyelvet akik tanítják, most nem a tanárok, hanem ez a program, ez az amióta én tanítok, meg még lehet, hogy nekünk is ugyanaz volt. Tehát egy középiskolai szerb tankönyvet kinyitsz, ilyen 'Ivo Andrić Na Drini Ćuprija', tele török szóval, meg 'Gorski Venac', tehát ilyen régi, nehéz szövegek részei vannak kiszedve...Hát nem lenne

${ }^{65}$ vizsgázni 
egyszerübb, hogyha valami, mondjuk az angol nyelvre amik vannak ilyen új könyvek, amik tele vannak ilyen fiatalos valami témákkal, mind ilyen régi középkori nyelvjárású valamiket, se nem érdekli öket, se nem értik, de én sem értem sokszor, meg ezeket a középkori epikus „epska pesma“...Nézem, hogy most ebböl kell tanitani a szerbet? Most van egy kis kolléganönk, megy majd nyáron valami szemináriumra, és van neki egy ilyen szerb könyve, ami ez modern stílusba, általános iskolákra van. Ö azt hozza, és ö abból tanit a gyerekeknek. Hivatalosan biztos nem azt írja be, vagy nem tudom..." (interjúrészlet, pedagógus-Z3, Zombor,2014).

\subsection{Az iskola jellemzése és az iskolában folyó oktatás}

Az egyik nagykikindai pedagógus úgy vélekedett, hogy a szülöknek jó véleményük van az iskoláról, és a jó vélemény kialakításában nagy szerepet játszik az, hogy igyekeznek az szülőket minél jobban bevonni az iskola életébe, különböző programokon keresztül. A legutóbbi közös program a farsangi ünnepség volt, ahol a szülők segítettek a játékok és a vetélkedők kialakításában, megszervezésében. Az iskola pár évvel ezelőtt bevezetett egyfajta iskolalátogatási rendszert, ami azt jelenti, hogy minden egyes tanár külön osztályokban várja az iskolába látogató szülöket. Ilyenkor a szülö odamehet mindegyik tanárhoz és saját gyermeke osztályzatairól érdeklődhet. Ezt a fajta iskolalátogatást általában szombati napokon szokták megszervezni. A szülők nagyon elégedettek ezzel a rendszerrel.

A szülök elmondása szerint elégedettek az iskolával és az iskolában oktató tanárokkal is. A szülök közül néhányan panaszkodtak arra, hogy szerinte manapság a tanárok már nem olyan elhivatottak, mint régen, valamint nehezebben megy a kommunikáció a tanárok és a szülők között.

A diákok és a szülők mindhárom mintaterületen egybehangzóan azt mondták, hogy nagyon fontosnak tartják a szerb, illetve az idegen nyelvek oktatását is, viszont több szülö szóvá tette, hogy véleményük szerint elég lenne csak egy idegen nyelvet tanulniuk, tehát vagy csak németet, vagy csak angolt, mert gyermekeik túlságosan le vannak terhelve. A gyerekek véleménye szerint, ők maguk alapszinten beszélik az idegen nyelveket, a szerbet pedig „száz százalékosan”.

Egy nagykikindai szerb tanárnő elmesélte, hogy ő arra törekszik, hogy a diákok is aktívan részt vegyenek az órákon. Kerüli azt a módszert, hogy kiáll és egész órán át csak ő beszél, a gyerek pedig csak ülnek és hallgatják öt. Elmondása szerint sokat használja az internetet, a projektort, továbbá hangos könyveket, és CD-ket is alkalmaz, hogy érdekesebbé tegye az óráit. A tanárnő a következőket mondta el saját órájával kapcsolatban: „... szeretek minél több dolgot vizuálisan is bemutatni és minél több gyereket aktivitásra ösztönözni az órán. A szerb nyelv elég terjedelmes és sokoldalú. Nem csak nyelvtanból és irodalomból áll, hanem összeköthetö a színházzal, a múzeummal, a filmekkel, a zenével, az informatika órával és a kultúrával, egyszóval nincs határ. Szeretek együttmüködni a könyvtárral és néha órákat tartunk a múzeumban is. Mindig igyekszem érdekessé tenni nekik az órát, hogy minél több minden megmaradjon bennük és ez által minél több mindent megtanulhassanak. Mindannyian ezt tesszük az iskolában. Ami a tankönyveket illeti, több kiadótól vannak tankönyveink, amit minden tanár a saját belátása szerint választ ki. A tananyag ugyanaz, de minden tankönyv másmilyen, mert különbözö a kiadójuk... Amikor Csókán dolgoztam, a szerb nyelvet mint környezetnyelvet tanítottam az általános iskolában, a középiskolában pedig mint anyanyelvet. Csókán nagyon kevesen voltak azok, akik nem tudtak magyarul és néha elszégyelltem magam, amiért abban a környezetben én nem tudtam magyarul, mivel mégis csak olyan környezetben élünk, ahol egyformán beszélik a két nyelvet. Szerintem itt ebben a környezetben (Kikindán) a magyar anyanyelvü gyerekek jól tanulnak szerbül. Az óvodában szerb anyanyelvü gyerekekkel 
játszanak és könnyebben tanulják meg a szavakat. Ugyanúgy a szerb anyanyelvü gyerekek is sok szavat hallanak a magyar ajkú barátaiktól. Az utcán egyaránt lehet a magyar és a szerb beszédet is hallani. Úgy gondolom, hogy erre szükség van, mivel ilyen környezetben élünk. Az Észak-Bánáti Körzet vegyes összetételü. Mindenkinek tudnia kellene a két nyelvet, de sajnos nekünk nem volt hol megtanulnunk. Valamennyit meg értünk magyarul, de ez csak a környezet hatásának köszönhetö" (interjúrészlet, pedagógus-K1, Nagykikinda, 2013).

Egy Nagykikindán tanuló diáklány, aki szerb nyelven végzi tanulmányait, arra a kérésemre, hogy emeljen ki három pozitívumot az iskolájával kapcsolatban, azt válaszolta, hogy örül, hogy iskolájában magyar tannyelvü osztály is létezik, mert így iskoláját „többnek” érzi.

„Jónak tartom az iskolámat. Legpozitívabb dolog, hogy szerbek és magyarok is járnak az iskolába, és látszik, hogy semmi különbség nincs köztünk, egyformák vagyunk.” (interjúrészlet, diák-K4, Nagykikinda, 2013).

\subsubsection{Az iskola marketing tevékenysége}

A címben megjelölt téma igen fontos a kutatás szempontjából, hiszen a diákok létszámfogyására reflektálva az iskolák komoly marketing tevékenységet folytatnak, ahol mindinkább próbálják felhívni a szülök és a diákok figyelmét iskolájuk előnyeire, legyen ez akár a két tannyelvü oktatás.

A megkérdezett iskolákban egész éven át folytatnak marketing tevékenységet. Az első kutatási helyszínen, Nagykikindán az iskola kapcsolatban van a médiával, ami magába foglalja a rádiót, az újságot és a tévét. Ha bármilyen esemény történik az iskolában az megjelenik a médiában: példának okáért közzéteszik a diákok versenyeken elért eredményeit. Ezen kívül az iskolának saját facebook profilja, és saját weboldala is van. Ily módon kapcsolatban vannak a diákokkal és a szülőkkel is. Mindamellett az iskolának kapcsolata van az óvodákkal, és ennek köszönhetően az óvodások minden évben ellátogatnak az iskolába, ahol a tanítónők fogadják őket.

„,... volt is egy óvoda, ahol minden év végén szülöértekezletet szerveztek, és mindig meghívták a két magyar iskolából a párhuzamos tagozatok tanitónőjét, akik az első osztályos diákokat fogadták volna a következö évtöl. Én ekkor úgy éreztem, mintha elárusítanám magam, mintha egy kiállitó teremben ülnék és ,,méricskélnek” a szülök, na, most ez a tanitónö legyen vagy a másik. Érveket mondott az egyik és a máik tanitó nö is. Véleményem szerint, ezt másképp kellett volna megoldani. Inkább a tanárokat, tanitókat nézik a szülök, hogy hogyan dolgoznak, valamint az iskola marketingje is nagyon sokat jelent..." (interjúrészlet, pedagógus-K3, Nagykikinda, 2013).

Az újvidéki pedagógusok szintén beszámoltak arról, hogy az az iskola, amelyekben tanítanak, folyatat marketing tevékenységet, söt különféle pályázatokon is aktívan részt vesznek. Az iskolák által szervezett előadásokon bemutatják az iskolákban folyó oktatást, és emellett külön programsorozatok keretén belül beszélnek a magyar oktatás sajátosságairól, és igyekeznek felhívni a magyar nemzetiségü szülők figyelmét arra, hogy iskolájukban lehetőség van magyar nyelven tanulni. Több interjúalanyom véleménye szerint ezen a bemutatón az utóbbi években több tanító vett részt, mint szülő. A nehézségek ellenére elmondták, hogy ezeket a programsorozatokat mindenképpen érdemes folytatni, hiszen a szülők így „első kézből” kaphatnak információt az iskoláról, a tantervről, tanítókról, és tanárokról. 
„Néhány évvel ezelött csináltunk az iskoláról egy ilyen bemutató-szerüt, amihez szöveg is járt és képek az iskoláról, és ezt már párszor be is mutattuk nyilvánosan is, tehát itt az iskola elönyeiröl van szó, a tanárokról, mi mindent kaphatnak ettöl az iskolától. Ez egy közös fórumon szokott történni, és minden iskola ott bemutatkozott. De ez sem olyan aktuális már, mert hát általában többen voltunk mi tanitók, mint szülök, mert nehezen jönnek el a szülök ilyesmire, és a tapasztalat az, hogy aki eljön, az már úgyis eldöntötte, hogy magyar iskolába adja a gyerekét, mondjuk egy százaléka azoknak, tíz emberböl mondjuk egy, nem biztos abban, hogy magyar iskolába akarja íratni a gyerekét” (interjúrészlet, pedagógus-U3, Újvidék, 2014)

A pedagógusok egyöntetüen kijelentették, hogy véleményük szerint, nagyon fontos, hogy egy iskola marketing tevékenységet folytasson, hiszen, így a szülök jobban megismerhetik az iskolában folyó oktatást, valamint a diákok versenyeken elért helyezéseiről is tájékozódhatnak, ami növeli az iskola jó hírét. Különösen fontosnak tartják ezt a tevékenységét, mivel általában a települések lakosságszáma csökken (főleg a magyar nemzetiségüeket figyelembe véve), így az iskolák versenyhelyzetbe kerülnek a diákokért. A pedagógusok elmesélték, hogy az egyik legfontosabb tevékenységnek azt tartják, hogy az óvodások részére müsorokat és egyéb foglalkozásokat szerveznek, ahol a leendő kisiskolások és szüleik megismerhetik a tanítókat/tanárokat.

„A marketing tevékenység az nagyon fontos, és nagyon nagyban függ a hírnévtöl is, ha ezen nem dolgozunk, akkor, akkor másik iskolába fogják íratni a szülök a gyerekeket. Innentöl kezdve, akár osztályok is szünhetnek meg...Ügy reklámozzuk magunkat, hogy terjesztjük a jó hírt, hogy milyen jó dolgok történtek az iskolában...a komoly jó híreket kell terjeszteni" (interjúrészlet, pedagógus-U2,Újvidék, 2014)

„... tehát, ugye mivel nagy mértékben csökken a lakosság száma, ezért a városi iskolák, több iskola is van, ilyen versenyhelyzetbe kerültek, és már hosszú évekre tekint vissza az a tevékenységünk, hogy járjuk az óvodákat, és az óvodások számára az alsósok müsorokat szerveznek, és erre jönnek el az óvodások ezeket megnézni, és az utóbbi három évben pedig téli foglalkozásokat tartunk számukra, ahol a téli szünetben a szülök behozzák az óvodás korú gyerekeket, és akkor velük foglalkozunk. ...Megismerik a tanárokat, az osztálytanitókat, szülők is itt lehetnek, beszélgethetnek velünk” (interjúrészlet, pedagógus-Z8, Zombor, 2014)

\subsection{Továbbtanulási lehetőségek/jövőkép}

A megkérdezett diákok fele válaszolta azt, hogy egyetemen szeretne tovább tanulni. Ők a továbbtanulást leginkább Újvidéken, vagy Nagybecskereken képzelik el, szerb nyelven. Egy diák mondta azt, hogy ő német nyelven szeretne majd az egyetemen tanulni. Az esetek túlnyomó többségében a szülők támogatják a gyermekeik felsőfokú tanulmányait, és véleményük szerint gyermekeik szerb nyelven fogják majd tanulmányaikat folytatni.

„... Nem tudom, hogy ö mit akar befejezni. Ha tovább szeretne tanulni, akkor Újvidékre, vagy Zrenjaninba megy majd, és valószínüleg szerb nyelven folytatja majd a tanulmányait, mivel egy éves korától szerb nyelven tanul. Mindent szerbül tanul. Nem fogom eröltetni neki a magyar nyelven való továbbtanulást, mert nem értené meg magyar tagozaton azt, amit kellene. Neki a szerb nyelv nem gond...” (interjúrészlet, szülö, Nagykikinda, 2013). 
„... Szeretném, ha nyelveket tanulna a lányom, angolt és németet. Úgy látom, hogy mostanában ez az, ami keresett, valamint az informatika. Elötte természetesen be kell, hogy fejezzen egy középiskolát, egy négyéveset. Most már szerbül fog tovább tanulni, így kezdte, így is fogja befejezni. Meg a magyar egy kicsit nehezebben megy, megért mindent, de nem nagyon beszél...” (interjúrészlet, szülö-K10, Nagykikinda, 2013).

„... Szeretném, ha befejeznék az általános iskolát és utána azt szeretném, hogy kitanuljanak valamilyen szakmát, ne szenvedjenek, mint én. Milyen nyelven tanuljanak majd tovább, hát biztosan szerbül fognak tovább tanulni, mert magyarul nem is nagyon tudnak..." (interjúrészlet, szülö-K11, Nagykikinda, 2013).

„,nem tudom, lehet, hogy külföldön élek majd” (interjúrészlet, diák-U11, Újvidék, 2014)

„a müszakiba, de utána nem fogok tovább menni, és szerbül megyek” (interjúrészlet, diákZ11, Zombor, 2014)

A pedagógusok a továbbtanulási lehetőségekkel, és a jövővel kapcsolatos kérdésemre egybehangzóan az elvándorlás jelenségére, és az ebből fakadó demográfiai problémákra hívták fel a figyelmet.

„Hát, egyrészt az, hogy, ugye, el is költöznek, ugye, úgyhogy volt diákjaink, amelyek most szülök, ugye, a gyermekei most kerülnének, mondjuk a középiskolába, azok már elköltöztek. Másrészt viszont vannak olyanok is, amelyek, mint ahogy én jártam, ugye, hogy az általános iskolától már szerb osztályba írassák a gyermekeiket, mert úgy gondolják, hogy könnyebben érvényesülnek ebben az országban, vagy vegyes házasságból, és akkor azért mennek szerb osztályba, vagy, mondjuk rá, itt sajnos, a, a környéki falvakból tehát Szabadka felé gravitálnak, vagy Baja felé a diákok, az általános iskola befejezése után, úgyhogy akkor ott folytatják, mert ott több szak van Szabadkán magyarul, tehát a, a mezögazdasági középiskolában, akkor a müszaki iskolában, az egészségügyiben is általános szak is van, akkor a gimnáziumban van külön természeti, természettudományi, társadalmi, általános, úgyhogy akkor van ez a Tehetséggondozó Gimnázium, akkor sport, nyelv, ilyen sport gimnázium, úgyhogy akkor vagy odamennek, vagy mondom, Bajára, akik szeretnék Magyarországon később folytatni az egyetemet, úgyhogy Bezdánból, például, sokan Bajára mennek gimnáziumba." (interjúrészlet, pedagógus-Z2, Zombor,2014).

Több tanár kiemelte föként Zomborban, hogy a tannyelvválasztás megkezdése előtt a szülök felbecsülik saját anyagi kereteiket, mérlegelik a továbbtanulási esélyeket, és ha nem tudják a gyermekeik részére anyagilag biztosítani a külföldön (Magyarországon) történő továbbtanulás lehetőségét, akkor úgy vélik, hogy jobb, ha gyermekük részére általános iskolától fogva szerb nyelvü oktatást választanak. Viszont, ha a szülök anyagilag megengedhetik maguknak a külföldi taníttatást, akkor annak a diáknak jelentősen fel kell zárkóznia, hiszen a magyar oktatási rendszer részben eltér attól a rendszertől, amelyben a diák eddig tanult.

„Föleg, hogy ha most azok a szülök, akik valamiféleképpen tudják finanszirozni a gyerek, hogy most Pesten, vagy, vagy Szegeden, vagy máshol folytassa Magyarországon a tanulmányait, akkor még oké, de viszont az ökonómiai helyzet miatt elég sok szülö ezt nem tudja, és akkor maradtak a, az itteni, tehát a vajdasági középiskolák, viszont magyar nyelvi szakokból nincs nagy választék. Például, itt minálunk konkrétan egy magyar osztályunk van, 
azok gyógyszerészek, viszont, hogy ha valaki most ebben az esetben konkrétan növér szakmát tanulna inkább ki, vagy ezt a fizioterapeutát ${ }^{66}$ igen, azt nem tudná magyarul csinálni, azt kellene akkor szerb nyelven. Épp ugyanúgy van a müszaki középiskolában is, ahol nincs akkora nagy választék magyar nyelven, vagy most nem tudom, hogy a többi iskolában, de ott sincs olyan nagy választék, és hogyha szerbül menne tovább középiskolába, akkor nagyobb a választék, tehát több lehetösége van hallgatni a tanitást, kitanulni azt a szakmát, ami pedig az egyetemet illeti ugyanaz a helyzet. Tehát ott is megvan, hogy van egy pár szak, amit lehet magyarul beírni, de, viszont a javarésze szerbül van. Tehát ez nem kizárólag a középiskolák, meg az egyetemek hibája, tehát egyrészt kevesebb a gyerek, tehát magyar diákok is kevesebben vannak, akik beírnák a középiskolát, másrészt tanárokból is hiány van, akik magyarul is tudnának tanítani, tehát az a másik probléma." (interjúrészlet, pedagógus-Z4, Zombor).

„Azok, akik zsebbel is bírják, gyakran gondolkoznak abban, hogy Magyarországon tovább folytatják tanulmányaikat. Véres tanulmányok. Mert az ottani oktatási rendszer meg se, nem lehet összehasonlítani. Tehát a mi oktatási rendszerünk nincs azon a nívón, mint amilyen a magyar. Tehát a mi diákjaink, az első két évben, mikor elmennek középiskolába, rettenetesen kell, hogy tanuljanak, rettenetesen kell, hogy mutassanak valamit, hogy hozzájuk tudjanak igazodni. Azok a követelmények megközelíthetetlenek, a mi diákjaink számára. Tehát a mi nagyon jó diákjaink ott nagyon megfogják, sokat csalatkoznak abban..." (interjúrészlet, pedagógus-Z5, Zombor,2014).

\subsection{Anyanyelvápolás és a nyelv ,presztízse”}

Azoknak a magyar nemzetiségü diákoknak, akik szerb tannyelvü osztályokban tanulnak, lehetőségük van részt venni az anyanyelvápolás órán, amely fakultatív. A Nagykikindán megkérdezett diákok közül senki sem tanul az iskolán kívül magyarul. Egy diák mondta azt, hogy ő számítógépen keresztül néha szokott magyarul tanulni. Ezzel ellentétben az Újvidéken megkérdezett diákok többsége jár anyanyelvápolás órára, míg a zombori mintaterületen kutatásba bevont diákok mindegyike járt külön magyar órára.

„Nincs környezetnyelv, azt beszüntették, ez anyanyelvápolás. A magyar mint környezetnyelv kötelezö volt régebben, de most nem kötelezö, most ez választott tantárgy egytöl nyolcig. A tantárgy neve az, hogy anyanyelvápolás, de ez már nem anyanyelvápolás, hanem inkább nyelvtanulás, de erre nincs konkrét program, a tanárok magukra vannak hagyva, hogy miböl dolgoznak, de feltalálják magukat...Külön veszem azokat a gyerekeket, akik nem tudnak magyarul, és külön veszem azokat, akik már tudnak, van, akinél ápolni kell a nyelvet, de van, akinél meg el kell ültetni a nyelvtudás alapjait. Szerbül is beszélünk órán, nem tudom azt alkalmazni, hogy csak magyar utasitásokat adok, van, akivel lehet, van, akivel nem, amennyire lehet kerülöm a szerbet, de egyszerüen van, amikor muszáj szerbül beszélnem, mert máskülönben nem érti meg la gyerek/” (interjúrészlet, pedagógus-U5, Újvidék, 2014).

${ }^{66}$ gyógytornász 
Puskás Tünde tanulmányában kifejti azt az álláspontot, miszerint általánosságban elmondható, hogy ha egy adott nyelvet beszélő közösség hatalommal bír, és nagy presztízsre tesz szert, akkor a nyelv presztízsértéke is megnő (PUSKÁS T. 2000). Susan Gal véleménye szintén ezt az álláspontot támasztja alá. Elmélete szerint egy kisebbségi nyelv ereje megnő, ha az a nyelv összeköti beszélőit szimbolikusan és gyakorlatilag is egy gazdaságilag és politikailag fejlettebb hatalommal (GAL, S. - WOOLARD, K. 1995). Összegezve azt állíthatjuk, hogy a gazdaságilag és kulturálisan sikeres közösségek nyelve sikeres (FoDOR D. 2005a). Ezen állításhoz kapcsolódva egy Újvidéken tanító pedagógus a következőképpen beszélt arról, hogy a kettős állampolgárság megszerzése milyen kihatással van a magyar nyelv megítélésére, illetve véleménye szerint a magyar nyelv presztízse az utóbbi időben megnőtt, és ez a piaci és a politikai „mechanizmusoknak” is köszönhető.

„... mert a magyar, csak nem olyan tekintély, de azért most kezd egy kicsit visszakapaszkodni, a magyar mint nyelv, meg mint tekintély, mert mondjuk egy tíz évvel ezelött, nagyon nehéz helyzetben voltak a tanárok, akik magyarul tanitottak, szinte nem is nagyon mertek bekopogni egy-egy osztályba, hogy ekkor meg ekkor lesz a magyar óra, mert hát ez nem volt trendi, most valahogy kicsit érdekes, mert a kettös állampolgárságból kifolyólag sok minden változott....van egy nosztalgia, hogy az ómamám magyar volt, meg Osztrák-Magyar Monarchia meg nem tudom én mi, és most kapálunk a magyar állampolgárságért, mert így egy kis út nyílik a nyugat felé. Ez hozza most azt, hogy de jó lenne magyarul tudni, de sajnos nem beszélek magyarul. De ha itt jobb lenne a gazdasági helyzet, nem is annyira lenne érdekes ez a magyar...” (interjúrészlet, pedagógus-U5, Újvidék, 2014).

A pedagógusok véleménye szerint Zomborban, a magyar nyelv mint választható tantárgy oktatására nagy igény mutatkozik, amelyet nemcsak a vegyes házasságból származó diákok vesznek igénybe, hanem a szerb és horvát anyanyelvü diákok is. Egy interjút adó pedagógus véleménye szerint a nyelv presztízsének növekedése részben a szerb-magyar állami/politikai viszonyok rendeződésének is köszönhetö.

„Választható tantárgyként van a magyar, nagy igény, nem csak a vegyes házasságból származó diákok, hanem szerb vagy horvát anyanyelvü diákok is választják a magyart mint környezetnyelvet, föleg az utóbbi idöben, ahogy a szerb-magyar állami viszonyok kezdtek rendezödni, akkor egyre nagyobb igény mutatkozott erre, ezen kivül a horvát és a bunyevác nyelvet lehet szabadon választott nyelvként tanulni még az iskolában. És a kötelezö idegen nyelvek, azok a német és az angol, amit tanulnak a gyerekek. Az angolt elsö osztálytól, a németet pedig ötödik osztálytól kezdödöen tanulják" (interjúrészlet, pedagógus-Z8, Újvidék, 2014).

\subsection{Környező kisebb falvak problémái}

A kutatás Vajdaság községközpontjaiban készült, a közigazgatásilag a községhez tartozó kisebb (falusi) településeken a módszertan szerint nem történt lekérdezés, mégis az interjúkészítés során többször felmerültek a környező települések társadalmi, oktatási, és térbeli folyamatai. Annak ellenére, hogy információim másodkézből származnak, mégis fontosnak tartom felvetni az interjúalanyok által elmondottakat, így kiegészítve a kutatás fő vonalát. 
Az előző elemzésekből kiderült, hogy általában az a jellemző a községközpontokban, hogy vegyes nemzetiségű családok esetében a szerb nyelvü iskola mellett döntenek. Fordított a helyezet viszont a községhez tartozó magyar többségü falvakban, ott a vegyes házasságból született gyermekeket is többnyire magyar nyelven iskoláztatják, tehát a környezet és az a nemzetiség, amely többségben van egy adott településen, döntő befolyással bír a gyermek nyelvhasználatára, és ezáltal a későbbiekben az oktatási nyelv megválasztására is.

„... nagyon ritka az, hogy a vegyes házasságból már magyar tagozatra íratják a gyerekeket, tehát inkább az a jellemzö, hogy a vegyes házasságokból már szerb tagozatra íratják. A falvakban viszont éppen ez érdekes módon fordítva van, tehát ott többnyire amellett vannak, hogy azért magyar tagozaton folytatják a vegyes házasságból származó gyerekek is a tanulást” (interjúrészlet, pedagógus-Z8, Zombor, 2014)

Arra a kérdésemre, hogy a magyar nemzetiségü diákok milyen szinten beszélik az államnyelvet, a pedagógusok egybehangzó véleménye szerint, a községközpontokban élő magyar nemzetiségü gyerekek nagyon jól elsajátították a szerb nyelvet, főleg a társadalmi környezetüknek köszönhetően, viszont a pedagógusok többsége kiemelte azt is, hogy a községhez tartozó főleg magyar nemzetiségüek által lakott kisebb falvakban a gyermekek nagyon alacsony szinten beszélnek szerbül, és ez a jövőre nézve, föleg a továbbtanulási esélyekben és a munkaerö-piaci kérdésében komoly gondokat vet fel.

„Na, most Zomborban még igen, mert van alkalmuk, ugye, szerb gyerekekkel barátkozni, de a környéki falvakból, tehát magyar lakta falvakból a gyerekek, azok nem. Tehát aki nem barátkozik, aki nem olyan falurészen lakik, ahol van szerb gyerek is, tehát és nincs kontaktusban a nyelvvel, az nem. Tehát alig, hogy értenek valamit. És ez nagyon nagy probléma, mert, mondjuk rá, a szerb tanárok is panaszkodnak, hogy egyszerüen nem bírnak kommunikálni a gyerekekkel, és ök az általános iskola elsö osztályától tanulnak szerbül. Akkor az a kérdés, hogy mit tanulnak, jó, én nem mondom, hogy minden gyerek, megszólal angolul, vagy németül, aki idegen nyelvként az angolt, vagy a németet tanulja, de szerintem azok is többet tudnak, mint a gyerekek a szerbet, mint a környezet nyelvet. Úgyhogy ök sok nehézséggel szembesülnek, de akiben van ambíció, az, az küzd, és az nagyon sikeres tud lenni..."(interjúrészlet, pedagógus-Z2, Zombor,2014).

A tanárok azt is megemlítették, hogy a környezettől is nagymértékben függ, hogy a magyar nemzetiségü gyerekek milyen szinten sajátítják el a szerb nyelvet. Elmondták, hogy azok a diákok, akik magyar nyelvű környezetben nőttek fel, ők nem igazán értették, és nehezen beszélték a szerb nyelvet, és ez a középiskolákban gondot jelenthet. Hiszen, a szórványterületeken magyar ajkú előadó tanár hiányában egyes tantárgyakat gyakran szerb nyelven oktatnak, és ebben az esetekben, ezek a tanulók nem tudják követni az órán elhangzottakat.

„Ez, hát, környezettöl függ. Most itt Zombor községben általában a gyerekek még elég jól beszélik a szerbet, ha mást nem, kézzel, lábbal, de meg tudják magyarázni, viszont volt már alkalmam olyan gyerekeket tanítani, akiknek a szerb egyáltalán nem ment. És akkor az, az problémás, de például, van ilyen tantárgyakat kénytelenek szerbül hallgatni, mert magyar nyelvü tanár, vagy magyar ajkú tanár nincsen per pillanat, például, például a latin tanár, az nálunk elég ritka, az az egyik, például az ilyesmi, és ha éppen az iskolának nincs lehetösége magyar ajkú tanárt valamilyen tantárgyra biztosítani, mert nem mindig sikerül, tehát vagy valaki jelentkezik, vagy sem...abból a szempontból, az elég problémás a gyereknek, mert 
akkor, akkor, tehát nem érti azt, amit a tanár magyaráz, és akkor még plusz magyarázni, és akkor fordítani, akkor beszélni is nehezebben esik" (interjúrészlet, pedagógus-Z4, Zombor,2014).

„mivel a környezet nyelve a szerb, és itt föleg csak az iskolában, illetve otthon beszélnek anyanyelvükön, tehát a gyerekek rá kényszerülnek, kezdve a közintézményektöl a bolton keresztül, a mindennap során használják a szerb nyelvet, úgyhogy a zomboriak nagyon jól beszélnek szerbül. Ez viszont, azokban a falvakban, ahol a magyarok alkotják a többséget, mint pl. Telecska és Kupuszina, ott forditott. Ök alig tudnak megszólalni, mikor bejönnek Zomborba, és gondot okoz számukra az, hogy egy-két tantárgy szerbül van, de viszonylag elég jó, az utóbbi időben elég jól fel tudnak fejlödni egy szintre, és behozzák a hátrányokat" (interjúrészlet, pedagógus-Z8, Zombor,2014).

Az előző fejezetekben említést tettem arról, hogy szórványterületen, az alacsony gyermeklétszám miatt a tanulók gyakran összevont osztályokban tanulnak együtt. A pedagógusok szerint a kombinált tagozatokban sokkal nehezebb az oktatás, föleg ha nagy a korkülönbség a gyermekek között.

„Nagy baj, hogy az osztályokban négy-öt-hat diák van, de viszont, mondjuk, itt Doroszlót illetöen, úgy tudom, hogy az elsötöl a negyedikig van nekik összesen négy, vagy öt diák, elsőben egy diák iratkozott be, egy diák. Szilágyin is úgy tudom, hogy egy diák iratkozott. És ilyen kombinált osztályokat csinálnak, és, hogy most kombinált osztályba, én mikor beiratkoztam '71-ben, mi kombinált osztályba jártunk, elsö, második volt együtt, tehát a harmadikig együtt voltunk kombinált osztályként, és a tanító néni rendesen megcsinálta mindkét osztálynak, mindkét osztály nagyon jól tudott tovább fejlödni, úgyhogy mindegyikünk, amikor ötödikbe értünk, akkor nyolcan voltunk. Aztán buktak hozzánk, úgyhogy a nyolcadik végéig tízen lettünk. Tehát tíz diák fejezte be '79-ben az elemi iskolát Apatinban." (interjúrészlet, pedagógus-Z5, Zombor,2014).

azt is tudom, a Szilágyi az konkrétan falusi, hát, ott már kevert, ott olyan az elsö, második, elsö, harmadik össze van vonva, és a második, negyedik, ennyi a magyar gyerek...Ez van, még örülnek, ha nem csukják be az iskolájukat. Kupuszináról már arról is volt szó, hogy Kupuszináról utaztatják majd a gyerekeket, hogy a két magyar falut össze. Apatin községhez tartozik. Úgy hogy ilyenek.” (interjúrészlet, pedagógus-Z1, Zombor,2014). 


\section{Összegzés}

Az értekezésben lényegében négy fó rész különíthető el. Az első rész a disszertáció elméleti keretit, fogalmi hátterét és kutatási előzményeit elemzi, illetve ehhez a tematikus blokkhoz sorolható a dolgozat céljának, kérdéseinek felvázolása, és ennek módszertana is.

Az elméleti keretek és a kutatási módszertan bemutatása után a második nagyfejezetben kapott helyet Vajdaság Autonóm Tartomány földrajzi, gazdasági és etnikai megoszlásának ismertetése, ezen belül is a dolgozatban kiemeltem foglalkoztam a vajdasági magyarság demográfiai- és társadalomszerkezeti jellemzőivel. A tartomány földrajzi jellemzőinek részletezése után, a kutatási helyszínek (Nagykikinda, Újvidék és Zombor) területi és etnikai szempontú bemutatása következett.

A harmadik nagyobb egységben a kisebbségi oktatás jellemzői kerültek górcső alá, különös tekintettel a magyar kisebbségre. Ezen fejezetben azon tannyelvválasztási stratégiákat vázoltam fel, amelyek különböznek a vajdasági tömb- és szórványterületeken.

Az utolsó, negyedik nagyfejezet a terepi felméréseken gyüjtött kutatási anyag elemzését tárja fel, amelyben kiderülnek azok a fö motivációk és „mögöttes tartalmak”, amelyek alapján szórványban élök oktatási nyelvet választanak.

A dolgozat fó kérdését megválaszolva a gyermekek tannyelvválasztását egyéni, családi, mikroközösségi és földrajzi tényezők egyaránt befolyásolják. Mindemellett mind az elméleti, mind az empirikus kutatásból kiderült, hogy az oktatási nyelv megválasztása az iskolába iratkozó gyermekek és szüleik számára fontos kérdés. A vizsgálat igazolta, hogy a oktatási nyelv megválasztásakor nagyon fontos szerepet játszanak a nem etnikus tényezők, úgy mint a siker, a társadalmi érvényesülés és mobilitás.

A terepi kutatás során nyilvánvalóvá vált, hogy a szórvány területen domináló szerb kapcsolati háló következtében az évek során a családok belső nyelvrendszere megváltozott, az otthon beszélt nyelv a szerb nyelv lett. A szórvány területen a nyelvi preferencia akár már óvodáskor előtt a többségi nyelv irányába tolódhat el. A kutatás során, a legtöbb esetben a gyermekek tannyelv-választása a családban használt nyelvhez igazodott, tehát a megkérdezett szerb nyelven tanulóknak ezért nem okozott gondot az államnyelven történő tanulás.

$\mathrm{Az}$ általam megkérdezett diákok magyar vagy vegyes nemzetiségü családokból származtak, és inkább a szerb nyelvet tekintik anyanyelvüknek, mint a magyart. A tanulók (két kisdiák kivételével) saját elmondásuk szerint nagyon nehézkesen beszélnek magyarul. A szórványban élö, többségi (államnyelvű) oktatásban tanuló diákok egyre kevesebbet beszélnek anyanyelvükön. Az iskoláról való beszélgetés, a tanulás nyelve a szerb lett, ezáltal a magyar nyelv a legtöbb esetben csak a szükebb családra korlátozódik, vagy már az otthon keretein belül is elveszítette jelentőségét, tehát az anyanyelv háttérbe szorult, és csak egy szükebb térre korlátozódik (pl. nagyszülőkkel történő beszélgetés). A tanulók nagy többsége szüleikkel, nagyszüleikkel, testvérükkel és barátaikkal is szerb nyelven kommunikál. Ezeknek a tanulóknak, egy kisfiú kivételével nem okozott nehézséget az, hogy szerb tannyelvü iskolába íratták őket, hiszen a mindennapi kommunikáció során is szerbül beszélnek. Egy nagykikindai pedagógus szavaival élve ezek a tanulók már szerbül gondolkodnak. Mivel e családok többségében a mindennapi nyelvhasználatuk során szerb nyelven beszélnek, ezért a legtöbben a szerb tannyelvű iskoláztatást természetesnek tartották, valamint e mellé a későbbi „jobb” érvényesülés lehetőségét emelték ki fö szempontoknak.

Az iskola választás során magával az iskolával kapcsolatos szempontok közül a szülők a földrajzi elhelyezkedést, vagyis pontosabban az iskolától való távolságot és a családi tradíciót (a szülö, idősebb testvér, vagy a nagyszülő maga is ugyanabba az intézménybe járt), 
tartották az egyik legfontosabb szempontnak, illetve a tanító/tanítónő és az iskola hírneve szintén fontos tényező volt. A szülők közül senki sem említette az iskola felszereltségét vagy, hogy bármilyen etnikai elköteleződésböl választana iskolát. Az iskola közelségét és a családi tradíció tényezője mellett a következő szempontokat vették még figyelembe, amely befolyásolta az iskolaválasztást: a gyermek „erősebb” szerb nyelvtudása miatt természetesnek tekintették a szerb tannyelvü iskoláztatást (családi nyelvhasználathoz igazodtak), a későbbi érvényesülésre gondolva íratták a szülők gyermeküket szerb tannyelvü osztályba, az otthoni tanulás (lecke megírása) során nyújtott segítségnyújtás is fontos szempontnak bizonyult, továbbá az iskolaválasztás során a szülő saját negatív tapasztalata is közrejátszott. A felsoroltak alapján az iskolaválasztás döntésének hátterét és motivációit feloszthatjuk „bottom up” és ,top down” tényezőkre. „Bottom up” tényezőknek tekinthetjük a későbbi jobb érvényesülés lehetőségét, a tanulásban való szülői segítség nyújtást, illetve a szülő saját iskoláival kapcsolatos tapasztalatait. A ,top down” szempont pedig a gyermekek hiányos magyar nyelvtudása, hiszen ebböl fakadóan már egyes diákok nem tudtak volna bekapcsolódni a magyar tannyelvü oktatásba.

A többségi nyelvű iskoláztatás mellett döntő személyek, sokszor az anyanyelven történő oktatásban való részvételt társadalmi hátrányként, érvényesülésük útjában álló akadályként élik meg. Úgy vélik, hogy az a kisebbségi gyökerekkel rendelkező gyermek, aki az anyanyelvü képzésből kikerül, kevésbé lesz sikeres a munkaerö-piacon, hiszen (szerb) nyelvtudása gyengébb lesz azon társaikhoz viszonyítva, akik szerb nyelven végezték iskoláikat. Sok kisebbségi szülő nem is tartja fontosnak átadni a saját anyanyelvét gyermekének, és ekkor már megváltozik a család belső nyelvrendszere, amely később komoly kihatással van a tannyelvválasztásra is. Érdemes kiemelni, hogy a kutatásból kitűnik, hogy az elmúlt évek során a magyar nyelv presztízse megnőtt a szórványterületeken. Ez egyrészt a jelenleg fennálló pozitív politikai kapcsolatoknak, a kettős állampolgárság lehetőségének, és a különböző fejlesztési programoknak (pl. gazdaságfejlesztés, óvodafejlesztés) köszönhető.

Az interjúalanyok között több szülő vegyes házasságban élt, akik maguk is vegyes házasságban élő szülőktől származtak. Ezekben a családokban a gyermekek jobban beszélnek az államnyelven, mint magyarul, és ilyen esetekben a szülök teljesen természetesnek tartják, hogy gyermeküket szerb nyelven iskoláztatják, sőt jövőbeli terveik szerint a továbbtanulást is szerb nyelven szeretnék folyatatni. Ezek a terepi eredmények megegyeznek a dolgozat elméleti részében leírtakkal. A vegyes nemzetiségü családok többségében a nyelv átörökítésének folyamata megszakadt, a szerb nyelv vált domináns nyelvé, a legtöbb interjúalany esetében érezhető volt, hogy a magyar és a szerb szavakat összekeverik, tehát a nyelvromlás jelensége is megfigyelhető volt. A gyermekek nyelvtudása nem tette volna lehetővé, hogy magyar nyelven tanuljanak, tehát ilyen esetben evidens, hogy a hiányos nyelvtudás kihat a tannyelvválasztásra. A vegyes házasságokból születő gyermekeknél a tannyelvválasztás még nehezebb döntés, de legtöbbször a szerb szülő nyelvéhez „,igazodva”, szerb tannyelvü oktatást választanak a családok. A vegyes házasságból született gyermeket legtöbb esetben automatikusan szerb osztályba íratják, és sokszor a szülő nem is tarja fontosnak, hogy gyermekét megtanítsa magyarul, mivel az etnikai környezet többségében szerb nyelvü, és a magyar nyelvet már nem tartják annyira fontosnak. Utólag néhány szülő megemlítette, hogy sajnálják, hogy gyermekeik nem tudnak jól magyarul, és erre nekik, mint szülőknek jobban kellett volna figyelniük. Olyan érdekes esettel is találkoztam, ahol egy családban a három gyermek közül, a két idősebb magyar tagozatokon tanult, de a legkisebb gyermeket már szerb tagozatra íratták. Következésképpen egy családon belül az anyanyelv használata, a párválasztás, és az interperszonális kapcsolatok is befolyásolják az iskolaválasztást. 
Míg tömb területeken döntő tényező a gyermeknek a tanulásban segítő szülő anyanyelve, addig az interjúkból az derül ki, hogy esetenként a magyar szülőknek problémát okoz a magyar nyelven történő tanulásban való segédkezés, amely arra vezethető vissza, hogy a szülök a középiskolát, illetve a föiskolát szerb nyelven végezték és jelenleg is szakmájukból kifolyólag szerb nyelven beszélnek. Mindemellett az interjúkból az is kiderült, hogy a szórvány területeken domináló szerb nyelvű környezet következtében a diákok a későbbi érvényesüléshez szükséges magas szintü szerb nyelvtudással rendelkeznek.

A vizsgált községközpontokban (Nagykikinda, Újvidék, Zombor) az eltérő földrajzi elhelyezkedés ellenére az iskolaválasztást tekintve hasonló folyamatok tapasztalhatók. Egyedüli kivételként viszont érdemes kiemelni, hogy Újvidéken nagyon erősen jelen van az szülők körében az a nézet, miszerint azért tartják előnyösebbnek a szerb tannyelvű osztályt, mert attól tartanak, hogy ők maguk nem tudnának megfelelő mértékben segíteni gyermekeiknek az otthon tanulás során (pl. házi feladat megírásában). Mindemellett fontos tényezőként szerepelt még az iskola közelsége.

A pedagógusok többségének véleménye szerint a vegyes házasságból született gyermekek esetében azt, hogy a gyermek mindkét kultúrkörben nevelkedik egyszerre, a gyermek hasznára kell fordítani, és előnyt kellene kovácsolni belőle. Mindemellett a pedagógusok meglátásai szerint a magyar anyanyelvü, „,magyarul gondolkodó” diákok jobban tudnak a későbbiekben érvényesülni, ha anyanyelvükön tanulnak. Természetesen fontos, hogy a szerb nyelvet megfelelő szinten sajátítsák el, ami a szórványterületeken nem okoz gondot a gyerekeknek. Ha a magyar anyanyelvü diákot szerb osztályba íratják, akkor szerb anyanyelvü társaikhoz képest le fognak maradni és a tapasztalatok azt mutatják, hogy a későbbi érvényesülés során kevésbé lesznek eredményesek.

A pedagógusok meglátásai szerint azokban a családokban, ahol a gyermekekkel kis koruktól kezdve a kisebbség nyelvén (esetünkben magyarul) beszélnek, a gyermekeket az iskolaválasztás során a családban beszélt nyelvhez kell igazítani. Ellenkező esetben, a gyermek önbizalma megrendülhet, hiszen nem fogja teljes mértékben érteni az osztálytanító által kért teendőket, emiatt a tanulásban le is maradhat, és társaihoz képest felzárkózásra lesz szüksége úgy a tanulásban, mint az államnyelvi kompetenciái fejlesztésében. Sok esetben ezek a diákok kívülállónak érzik magukat osztályukban, és ez kihat a fejlődésükre.

A pedagógusok továbbá arra is felhívták a figyelmet, hogy a szórványban élő szülöknek nem kell attól tartaniuk, hogy gyermekük nem fog tökéletesen megtanulni szerb nyelven, hiszen a környezet sajátosságainak köszönhetően, ezek a tanulók az általános iskola befejezése után hiánytalanul kommunikálnak az állam nyelvén. Mindemellett a legtöbb pedagógus kiemelte, hogy a magyar tömbterületen élő diákok esetében pedig fontos, hogy elsajátítsák az államnyelvet, hiszen ellenkező esetben önmagukat rekesztik ki a későbbi munkaerő-piaci és oktatási lehetőségekből.

A pedagógusok szerint az anyanyelvü oktatás mellett szóló legerősebb érv, hogy az alapismerteket és alapvető kompetenciákat a gyermek anyanyelvén képes legjobban elsajátítani. De mi a helyzet akkor, ha az anyanyelv már a gyermek kiskorától fogva háttérbe szorult? A családi nyelvi rendszer lehet, hogy már a szülők nyelvi preferenciájával megváltozott és a gyermekek már nem is beszélik anyanyelvüket. Ebben az esetben nyilvánvaló, hogy ezeket a gyermekeket már értelmetlen volna az anyanyelvű oktatásba kényszeríteni, hiszen ezek a gyermekek nehezen beszélnek már magyarul. A tannyelv kellő ismeretének hiányában alacsonyabb szinten teljesít majd, és ezáltal frusztrálttá válik, nehezen tart lépést a társaival és ez egyben meghatározza a későbbi iskolai életútját is. Itt nagyon fontos hangsúlyozni, hogy a tannyelv-választás során figyelembe vegyék a diákok nyelvi és kulturális hátterét. 
Végső összegzésként két bekezdésben foglalom össze kutatásom legfontosabb eredményeit és következtetéseit. Többnyire már a családi nyelvhasználat során eldől, hogy a gyermek mely tannyelvet fogja választani, amely kihatással van a tovább tanulás felsőbb szintjeire is. A tömbterületekhez viszonyítva a szórványban sok a vegyes házasság, és itt a magyar szülőtől függ, hogy gyermekét megtanítja-e saját anyanyelvére vagy sem, hiszen csak akkor beszélhetünk döntési dilemmáról a tannyelvválasztást illetően ha a vegyes házasságokból született gyermek mindkét szülő nyelvét beszéli. Itt kell megjegyezni a nyelvek presztízsének a fontosságát is. Az utóbbi néhány évben megerösödött a magyar nyelv presztízse a vajdasági szórványtelepüléseken, de még dinamikusabb erösödése volt érezhető az empirikus kutatást követően. Ez elsősorban az egyszerüsített magyar állampolgárság megszerzésével, és ezzel együtt a külföldön való munkalehetőség esélyével, valamint a jelenleg is tartó pozitív hangulatú magyar-szerb politikai kapcsolatnak köszönhetö. Mindemellett fontos kiemelni, hogy Magyarország támogatásával a Vajdaságban müködö Magyar Nemzeti Tanács több programmal és fejlesztéssel támogatta a magyar tannyelvü oktatást, amely során külön hangsúlyt fektettek a szórványterületekre. Ezek a projektek szinte a kutatással egyidejűleg, vagy azt követően indultak el. Az iskolabusz program, a beiskolázási program, illetve a tanévkezdési csomag kiemelt részét képezi annak a tervnek, amely lehetőséget szeretne biztosítani azoknak a szülőknek, akik a szórványban magyar nyelven kívánják taníttatni gyermeküket.

A kutatás során két fontos földrajzi aspektus játszott szerepet a szórványban a tannyelv megválasztása során. Egyik maga a település etnikai összetétele, amely során a kisebbség tagjai nem szerettek volna „kilógni a többségi nemzetből”, tehát emiatt jobbnak látták a szerb nyelvü oktatást. De e tényezö összekeveredik azzal a körülménnyel is, hogy a családoknak kiterjedt szerb nyelvü baráti/rokoni/szomszédi kapcsolatai vannak, amely szintén a település etnikai megoszlásával van kapcsolatban. Másik fontos földrajzi tényező a távolság/közelség faktora, hiszen a szülők számára nagyon fontos, hogy lakóhelyükhöz legközelebbi iskolába járjon gyermekük, és ez főleg Újvidéken lényeges elvárás, ami a város nagyságával van összefüggésben. Sőt, ugyanilyen fontos a szülőknek a magyar bölcsőde/ óvoda közelsége is. Ha a szerb nyelvü óvoda közelebb van, a szülők inkább oda íratják gyermeküket, és sokan ezt követően már úgy gondolják, hogy erre alapozva jobb ha gyermek ezen a nyelven kezdi meg általános iskolai tanulmányait is, hiszen ez az ország nyelve, amit a legtöbb esetben a hatalom és az érvényesülés nyelvének tekintenek.

A kutatás eredményeire építve, a jövőbeli felmérések tárgya lehet a községekhez tartozó kisebb falvak (nem a községközpontok) vizsgálata, illetve további irány lehet még megvizsgálni azokat a szülöket is, akik a magyar nyelvü oktatás mellett döntöttek a szórványban, mind a községközpontokban és azon kívüli településeken is, hiszen a térbeli elhelyezkedés és a települések etnikai összetétele mind befolyással bírnak. Mindemellett érdemes lenne további interjúkat készíteni azokkal a politikai személyekkel és szakemberekkel is, akik az oktatás vagy a szórványgondozás területén dolgoznak.

A többségi tannyelvválasztásnak külön figyelmet kell szentelni a kutatások során, a tannyelv ugyanis bizonyítottan befolyásolja a gyermek későbbi iskolai életútját. Lezáró következtetésként hangsúlyozni kell, hogy az iskolaválasztást befolyásoló szempontokat nagyon nehéz egymástól elválasztani, ezek a tényezők legtöbbször egymásra épülnek. 


\section{Summary}

Four main parts can be identified in the dissertation. The first part looks at the theoretical framework of the dissertation, analysing the conceptual background and the precedents of the research; the aims of the work, along with the listing of the questions and the methodology are also a part of this thematic block.

After presenting the theoretical framework and the methodology of the research, the second main chapter deals with the identification of the Autonomous Province of Vojvodina's geographic, economic and ethnic divisions, within which I deal in greater detail with the characteristics of the demographic and social divisions of the Hungarian population in Vojvodina. After detailing the geographic characteristics of the region, the research areas (Kikinda, Novi Sad and Sombor) are presented in terms of territory and ethnicity.

The third part examines the characteristics of minority education, focusing on the Hungarian minority in particular. In this chapter I describe education language choice strategies that differ in areas of ethnic block and ethnic diaspora communities.

The last, fourth main chapter reveals the results of the empirical research, and it uncovers the main motivations and the "underlying background contents" which form the basis of education language choice in the ethnic diaspora.

Answering the main question of the dissertation, the students' education language choice is influenced by individual, familial, micro-community and geographic factors. Moreover, both the theoretical and the empirical research show that choosing education language is an important question for both the children and their parents.

It became apparent in the empirical research that dominant Serbian connection network, the internal language system of the families has changed, and the language spoken at home has come to be the Serbian language. Language preference in ethnic diaspora areas often comes to be the majority language before preschool. Research showed that in most cases, education language choice corresponded to the language used within the family; thus, education in the state language did not cause any problems for the interviewed individuals studying in the Serbian language.

The students I interviewed come from Hungarian or mixed-ethnicity families and they consider Serbian, rather than Hungarian, to be their native tongue. The students (aside from two pupils), claim to speak Hungarian with difficulty. They study in the majority language and live in ethnic diaspora communities, and admit to using their native language less and less. The language used to speak about education, the one that is also used in education has come to be the Serbian language, and, in the cases of most families, Hungarian has become limited to use within the closer family, or it has already lost its significance, being forced into the background, becoming increasingly restricted in its use (speaking with grandparents, for example). The majority of the students communicate in the Serbian language with their parents, grandparents, siblings and friends. For these students (with the exception of one young boy), it caused no problems to be enrolled in Serbian education language classes, as they used Serbian as the language of everyday communication. To reiterate the words of an educator from Kikinda, these students think in the Serbian language. Since in the majority of the cases the families used the Serbian language as the language of communication in everyday situations, most considered Serbian as the natural choice for education language, and emphasized later, "better" opportunities as the main factor for their choice.

When choosing a school, parents consider geographical location, that is to say the distance between the home and the school, and family tradition (the parent, an older sibling, a grandparent attended the same institution) as the most important factors in making their 
choice. Other important factors include the reputation of the teacher(s) or of the institution. None of the parents mentioned the equipment or facilities of the school, or ethnicity as influential factors. Aside from proximity of the school and family tradition, the following factors were taken into consideration when making their choice: due to the child's better knowledge of the Serbian language, parents found it "natural" to enrol their children in a class with Serbian as the language of instruction (matching language use at home); they enrolled their child in a Serbian class because they considered it advantageous for later success and opportunities; studying together at home (completing homework) and helping their children was also proven to be an important factor, along with any negative experiences the parents themselves might have had in the course of their own studies. Based on these listed factors, we can divide the motivations and backgrounds of the made choices into "bottom up" and "top down" factors. Bottom up factors include later opportunities and success, helping the children study, and the parents' own experiences in schooling. Top down factors, on the other hand, are comprised of the lack of Hungarian language knowledge of the students, since those students that do not speak or understand the Hungarian language sufficiently would have struggled in their classes with Hungarian as the language of instruction.

Individuals who decide on education in the majority language often consider education in the native (minority) language to be a social disadvantage, an obstacle in the way of later success. They believe that children from a minority background who complete their studies in their native language will emerge from school to be less successful in the job market, as their knowledge of the Serbian language will be weaker in comparison with their peers who completed their studies in the Serbian language. Many minority parents do not even consider it important to pass their native language on to their children, and this changes the internal language system of the family, which affects education choice later as well. It is interesting to point out that research shows that the prestige value of the Hungarian language has grown in ethnic diaspora areas in recent years. This is partly due to the present positive political connections, to the possibility of dual citizenship, and to the various development programs available at this time (i.e. economic or preschool development).

Many of the interviewed subjects live in mixed marriages, and many of them come from interethnic families themselves. Children speak the official language better than Hungarian in these families, and in these cases the parents find it natural to educate their children in the Serbian language - furthermore, they plan on enrolling their children in Serbian language (post-) secondary institutions. In the majority of such families, the process of passing on language is interrupted, the Serbian language becomes dominant, and in the case of most interview subjects, the mixing of Hungarian and Serbian words (language attrition) was observed. The children's language knowledge was not sufficient to make it possible for them to study in Hungarian, and in such cases it is evident that the lack of language knowledge impacts education language choice. In the case of children, who born from mixed marriages, education language choice is an even more difficult decision to make, but in most cases, families choose the Serbian language as the education language, "adjusting" to the native language of the Serbian parent. Children from such families are in most cases automatically enrolled in Serbian education language classes by the parents, and they often do not consider it important to teach their children Hungarian, since the ethnic environment is primarily Serbian, and Hungarian is not considered as important. At the end of the interview, a few parents mentioned that they regretted the fact that their children do not speak Hungarian well, and admitted that they, as parents, should have paid more attention to this. I also came across an interesting case in which, within one family, of three children, the two older children studied in Hungarian, while the youngest was enrolled in a Serbian 
education language class. Thus, within a family, native language use, choice of partner, and interpersonal relationships all influence education language choice.

While in areas where the majority of the population is of Hungarian (minority) ethnicity, the native language of the parent that helps in studying is a deciding factor in education language choice, the interviews reveal that in some cases, it is problematic for Hungarian parents to help their children in their (Hungarian) studies, which can be chalked up to the fact that the parents completed their secondary- and post-secondary studies in the Serbian language, and use Serbian at their workplace. Furthermore, the interviews also revealed that as a consequence of the dominant Serbian language environment in ethnic diaspora areas, students had acquired an excellent level of Serbian language knowledge, one that is essential for later opportunities and success.

Despite the different geographic positions of the examined municipal centres of Kikinda, Novi Sad and Sombor, similar processes can be observed in terms of education language choice. The only notable exception is the fact that many parents in Novi Sad consider Serbian education language to be an advantage there for the reason that they fear that they themselves would not be able to sufficiently help their children study at home (i.e. in helping with homework). Moreover, the proximity of the school was also an important factor.

According to the majority of educators, in the case of children from mixed marriages, to be raised in both cultures should be turned into an advantage for the children. Furthermore, in the teachers" opinions, Hungarian students who "think in Hungarian" will be more successful in their further studies if their education language is Hungarian. Of course it is also important to learn the Serbian language well, which is not problematic for children from ethnic diasporas. If Hungarian-speaking pupils are enrolled in Serbian education language classes, experience shows that they will be less successful in their later studies.

Educators believe that children from families in which they speak the minority language (in our case Hungarian), the language of instruction should be adjusted to the language spoken at home. If this is not done, the child's self-confidence could suffer, since he or she will not be able to understand the teacher's instructions completely, which could cause the student to fall behind his or her peers, needing extra help in his or her studies and in developing official language competence. In many cases, students feel like outsiders in their class, which affects their development.

Teachers also highlighted that parents from ethnic diaspora communities should not worry that their children will not learn the Serbian language perfectly, since, thanks to their unique environment, these students use the official language flawlessly upon the completion of elementary school. Moreover, most educators also stated that in the case of students coming from territory of ethnic block, it is very important that the students learn the state language, as they exclude themselves from education and job-marked opportunities if they do not satisfy this requirement.

According to teachers, the most important argument on the side of native language education language choice is that basic knowledge and competences can be best acquired in the child's native language. But what happens when native language is of secondary importance in the lives of the students from a young age? It is possible that the family's language system has changed thanks to the parents' language preferences and the children do not speak their native language. In this case it is obvious that it would not make sense to force these children to study in their native language, since they struggle to speak Hungarian. Due to their lacking language knowledge, they would fail to achieve to a higher degree, which would cause the students to become frustrated and unable to keep up with their peers, and this could define their further path in life as well. It is important to emphasize that the language 
and cultural background of the pupils must be taken into consideration when choosing education language.

As a final summary, I will summarize the most important results and conclusions of my research in two paragraphs. In most cases, in deciding which language to use within the family, education language choice is also decided, which has an effect on the higher levels of education as well. In territory of ethnic diasporas have more mixed marriages than area of ethnic block, and in these marriages, it is up to the Hungarian parent whether the Hungarian language is taught to the child or not, since we can only begin to consider choices if the children speak the language of each parent. The importance of language prestige is also noteworthy. In the past few years, the prestige of the Hungarian language has increased in ethnic diaspora areas, but an even stronger dynamic growth was sensed after the empirical research had been completed. This is mostly due to the simplified process of acquiring Hungarian citizenship, with which come job opportunities abroad, along with the present perceived positive political relationship between the two nations of Hungary and Serbia. Besides this, it is important to mention that, with the support of the Hungarian government, the Hungarian National Council supports Hungarian education through a number of programs and developments in Vojvodina, in which emphasis was placed on ethnic diaspora areas. These projects were begun around the time of the research or just after research had begun. The school bus program, the enrolment program, and the school-starting package program are all part of the plan that ensures an opportunity for parents who wish to educate their children in the Hungarian language.

Two geographic aspects played an important role in the research. One is the ethnic composition of the town, which influenced the members of the minority not to "stand out from the majority ethnicity", causing them to opt for Serbian language education. But the factor is further complicated by the fact that the families have wide friend/relative/neighbour connections which are related to the town's ethnicity. The other important geographic viewpoint is the proximity factor, as it is important for parents that their children attend a school that is close to their home. This is an especially important expectation in the city of Novi Sad, where it is connected to the size of the city. Furthermore, the proximity of Hungarian day-care/preschool is equally important for parents. If the Serbian language preschool is closer to their home, parents would rather enrol their children in that institution, and building from here, most parents believe that it is better for their children to begin their elementary school education in the same language, as it is state language, which is, for the most part, considered to be the language of power and opportunity.

Building on these results, a future subject of study could be examination the smaller villages of municipalities (not municipal centres). Another point of departure could be the study of those parents who opt for Hungarian as the language of instruction for their children in ethnic diaspora communities, as well as in municipal centres or connected towns. It would also be worthwhile to interview politicians and experts who work in the education sector or in ethnic diaspora support.

Majority education language choice must also be considered in further research, as education language is proven to influence the child's later education path. As my closing sentence, I wish to emphasize that it is very difficult to separate the factors influencing education language choice, as they are connected and based on one another. 


\section{Felhasznált irodalom}

A.Gergely A. - GELSEI G. - GeRgely V. - HoRVÁth V. 2004: Nemzeti és etnikai kisebbségek. - In: GELSEI G. - GERGEly V. - HoRVÁth V. - RÁCZ M. (szerk.): A láthatatlanság vége. Társadalomismereti olvasókönyv. Alapítvány a Társadalomelméleti Kollégiumért, Budapest. pp. 99-120.

ANDOR M. - LISKÓ I. 2000: Iskolaválasztás és mobilitás. - Iskolakultúra, Budapest. 264 p.

ANDRIĆ E. 2003: A szerb nyelv hatása a magyar általános iskolás tanulók nyelvére Vajdaságban. - In: GÁBRITYNÉ MOLNÁR I. - MIRNICS Zs. (szerk.): Kisebbségi létjelentségek. Szórvány- és szociolingvisztikai kutatások. Magyarságkutató Tudományos Társaság, Szabadka. pp. 193-214.

ANDRIĆ E. 2004: Iskoláskori kétnyelvüség Vajdaságban. - In: PAPP GY. (szerk.): Mi ilyen nyelvben élünk. Magyarságkutató Tudományos Társaság - Szociográfiai Mühely, Szabadka. pp. 249-267.

ÁGYAS R. 2016: A vajdasági magyar fiatalok mérföldkövei: Továbbtanulás, jövőkép és önszerveződés. - In: GÁBRITY MOLNÁR I. (szerk.): Kutatások sodrásában. Az MTT 25. éve. Magyarságkutató Tudományos Társaság, Szabadka. pp. 119-132.

ÁRENDÁS ZS. 2012: Az iskolaválasztás elbeszélései. - Társadalmi Együttélés 2012/1. [Elektronikus dokumentum]

Forrás:http://epa.oszk.hu/02200/02245/00001/pdf/EPA02245_Tarsadalmi_egyutteles_2012_01_A rendas.pdf (letöltve: 2011.05.05.)

BABBIE, E. 2008: A társadalomtudományi kutatás gyakorlata. Balassi Kiadó, Budapest. 744 p.

BADIS R. 2011: Vajdasági magyar szórványban élők demográfiai helyzete. - Identitás Kisebbségkutató Mühely, Zenta. $17 \mathrm{p}$.

BADIS R. 2012: Látlelet a vajdasági magyarok demográfiai helyzetéröl. - Pro Minoritate 2012/3. pp. 27-38. [Elektronikus dokumentum]

Forrás:http://www.prominoritate.hu/folyoiratok/2012/ProMino12-3-03-Badis.pdf (letöltési idő: 2015.05.02.)

BAJMÓCY P. 2004: A népesség nyelvi, etnikai összetétele. - In: BECSEI J. (szerk.): Népességföldrajz. Ipszilon kiadó Kft., Békéscsaba. pp. 283-294.

BAJMÓCY P. 2009: Általános etnikai- és vallásföldrajz. - JATE Press Kiadó, Szeged. 117 p.

BALIZS D. 2015: Etnikai térstruktúra, asszimiláció és identitás a történelmi Vas megyében. Doktori (PhD) értekezés, SZTE TTIK. 150 p.

BARTH, F. 1996: Régi és új problémák az etnicitás elemzésében. - Regio 7.1. pp. 3-25.

BARTHA Cs. 1999: A kétnyelvüség alapkérdései. Beszélők és közösségek. Nemzeti Tankönyvkiadó, Budapest. 268 p.

BARTHA ZS. 2014: Az iskolaválasztás motivációs hátterének vizsgálata Erdélyben, hangsúlyosan szórványban. - Magyar Kisebbség: nemzetpolitikai szemle 72.2. pp. 60-84.

BERETKA K. 2012: Szerbia nyelvpolitikája a magyar nyelvhasználat szemszögéből. - In: EPELÉNYI K.- KÁNTOR Z. (szerk.): Térvesztés és határtalanítás: A magyar nyelvpolitika 21.századi kihívásai. - Lucidus kiadó, Budapest. pp. 237-270.

BERNSTEIN, B. 2002: Nyelvi szocializáció és oktathatóság. - In: A. JÁsZÓ A. - BóDi Z. (szerk.): Szociolingvisztikai szöveggyüjtemény. Tinta Könyvkiadó, Budapest. pp. 185-195.

BALOGH B. - BODÓ B. - ILYÉS Z. 2007: Előszó. - In: BALOGH B. - BODÓ B. - IlYÉS Z. (szerk.): Regionális identitás, közösségépítés, szórványgondozás. Lucidus Kiadó, Budapest. pp. 7-13.

BÁLINT S. 1991: Gyerek híján nincs iskola. - Létünk 21.3-4. pp. 269-281.

BELANKA Cs. 2007: Mezőgazdaság. - In: NAGY I. (szerk.): Vajdaság. Dialóg Campus Kiadó, PécsBudapest. pp. 256-259.

BELUSZKY P. - KOVÁCS Z. 2012: Vajdaság településfejlődése a rendszerváltozás után. - In: DÖVÉNYI Z. (szerk.): A Kárpát-medence földrajza. Akadémiai Kiadó, Budapest. pp. 553-555.

BICZÓ G. 2005: A szórvány-kérdés transznacionális dimenziói és a magyar szórványkutatás. - In: ILYÉS Z. - PAPP R. (szerk.): Tanulmányok a szórványról. Magyar Világok 2. Gondolat- MTA Etnikai-Nemzeti Kisebbségkutató Intézet, Budapest. pp. 21-42. 
BICZÓ G. 2007: A nemzetközi diaszpóra kutatás eredményeinek gyakorlati jelentősége a magyar szórványkutatásban. - In: BALOGH B. - BODÓ B. - ILYÉS Z. (szerk.): Regionális identitás, közösségépítés, szórványgondozás. Lucidus Kiadó, Budapest. pp. 15-27.

BODÓ B. 2003: Identitás és szórványdiskurzus. - Kisebbségkutatás 12.2. pp. 384-397.

BODÓ B. 2006: Értékek, nyelvhasználat-szórvány. - In: BAKÓ B. - SzOTÁK Sz. (szerk.): Magyarlakta kistérségek és kisebbségi identitások a Kárpát-medencében. Gondolat Kiadó - MTA EtnikaiNemzeti Kisebbségkutató Intézet, Budapest. pp. 20-44.

Bodó B. 2007: A szórványtól a nemzetig- és vissza. - Pro Minoritate 2007 (tavasz). pp. 63-72. [Elektronikus dokumentum]

Forrás: http://www.prominoritate.hu/ (letöltési idő: 2016.10.30.)

BodÓ B. - BALOGH B. - ILYÉs Z. 2007: Előszó. - In: BALOGH B. - BodÓ B. - IlYÉs Z. (szerk.): Regionális identitás, közösségépítés, szórványgondozás. Lucidus Kiadó, Budapest. pp. 7-12.

BODÓ B.- MÁRTON J. 2012: Magyar iskolaválasztás Erdélyben. - Kisebbségkutatás 21.3. pp. 418472.

BODÓ B. 2013: Magyar fiatalok többségi iskolaválasztása Aradon. - Kisebbségkutatás 22.4. pp. 3148.

BoDÓ B. 2014: Szórványról - másként. - Korunk 25.6. pp. 6-23. [Elektronikus dokumentum] Forrás: http://epa.oszk.hu/00400/00458/00605/pdf/ (letöltési idő: 2017.06.15.)

Boros L. 2008: A városi depriváció térbelisége - konfliktuselméleti megközelítés szegedi esettanulmányokkal. Doktori (PhD) értekezés, SZTE TTIK. 146 p.

BOURDIEU, P. 1996: Az oktatási rendszer ideologikus funkciója. - In: MELEGH Cs. (szerk.): Iskola és társadalom I. Szöveggyüjtemény. Janus Pannonius Tudományegyetem, Pécs. pp.10-24.

BRUBAKER, R. 2005: The "diaspora" diaspora. - Ethnic and Racial Studies 28.1. pp. 1-29.

CHOLNOKY GY. 2000: Vetési László: Iskola a nyelvhatáron. - Kisebbségkutatás 9.1. pp. 154-155. Forrás: http://epa.oszk.hu/00400/00462/00005/27.htm (Letöltési idő: 2016.04.22.)

CONDRON, D. J. 2009: Social Inequalities and Children's learning. - American Sociological Review 74. (October). pp. 683-708.

CSERNICSKÓ I. - GÖNCZ L. 2009: Tannyelvválasztás a kisebbségi régiókban: Útmutató kárpátaljai magyar szülőknek és pedagógusoknak. Magyar Köztársaság Miniszterelnöki Hivatala, 2009. [Elektronikus dokumentum]

Forrás: www.kmf.uz.ua. (letöltés dátuma: 2011.12.12.)

CSETE Ö. - PAPP Z. A. - SETÉNYI J. 2009: Kárpát-medencei magyar oktatás az ezredfordulón. - In: BITSKEY B. (szerk.): Határon túli magyarság a 21. században. Köztársasági Elnöki Hivatal, Budapest. pp. 125-165.

CLIFFORD, J. 1994: Diasporas. - Cultural Anthropology 9.3. pp. 302-338.

DÁNYI D. 1999: A szlovákiai szórványmagyarság. - Regio 10.3-4. pp. 161-206.

DE KLERK, V. 2001: The Cross - Marriage Language Dilemma: His Language or Hers? - International Journal of Bilingual Education and Bilingualism 4.3. pp. 197-216.

DoBOS F. 2011: Szociológiai kutatások a határon túli magyarság körében. Asszimilációs folyamatok az erdélyi, felvidéki, kárpátaljai és vajdasági magyarság körében 1996-2011. Kutatási jelentés. B Fókusz Intézet, Budapest. [Elektronikus dokumentum]

Forrás: http://www.kmkf.hu/tartalom/assszimilacio.pdf (letöltve: 2015.09.14.)

ĐERČAN, B. - BUBALO-ŽIVKOVIĆ, M. - SOLAREVIĆ, M. - ŠABIĆ, D. 2017: Living on the border: social indicators of life quality in Srem border region (Vojvodina, Serbia). - Geographica Pannonica 21.1. pp. 26-42.

DJuRdJEV, S. B. - KicoŠEV, S. - VuKSANOvić, G. 2003: Strenghts and Weaknesses of Human Resources in Reginal Development of Vojvodina Province. - Geographica Pannonica 7.1. pp. 2126.

ERDEI I. 2010: Többnyelvü környezetben élő gyerekek nyelvi szocializációja. PhD értekezés. Szegedi Tudományegyetem, Bölcsészettudományi Kar, Neveléstudományi Doktori Iskola, Szeged. 180 p. 
ERDEI I. 2011: Pedagógusok kétnyelvüséggel kapcsolatos nézetei. - In: HORVÁTH I. - TóDOR E. M. (szerk.): Nyelvhasználat, tannyelv és két (több) nyelvü lét. Nemzeti Kisebbségkutató Intézet, Kriterion Könyvkiadó. Kolozsvár. pp. 43-58.

ERÖSS Á.-FILEP B.-RÁCZ K.-TÁTRAI P.-VÁRADI M. M.-D. WASTL-WALTER 2011: Tanulmányi célú migráció, migráns élethelyzetek: vajdasági diákok Magyarországon. - Tér és Társadalom 25.4. pp. 3-19.

FARKAS GY. 2000: A nemzetiségi megoszlás térszerkezete vegyes lakosságú régiókban. „Nulladik” változat a nyelvhatárra - egy módszer próbája. - Fórum Társadalomtudományi Szemle 2.2. pp. $109-124$.

FERENC V. - SÉRA M. 2012: Iskolaválasztás Kárpátalján. - Kisebbségkutatás 21.3. pp. 473-513.

FERENC V. (2013): Nyelvet tanulni, továbbtanulni, „létesülni” - többségi iskolaválasztási stratégiák Beregszászban. - Kisebbségkutatás 22.4. pp. 98-121.

FiLIPOVIĆ, J. - VuČO, J. - DJURIĆ, LJ. (2007): Critical Review of Language Education Policies in Compulsory Primary and Secondary Education in Serbia. - Current Issues in Language Planning 8.2. pp. 222-242.

FODOR D. 2005a: Nyelvi attitüd, nyelvválasztás és nyelvcsere egy aranyosgyéresi kétnyelvü családban. - Kisebbségkutatás 14.2. pp. 253-263.

FODOR D. 2005b: Nyelvhasználat és nyelvi attitüd tordai magyar-román vegyes családok körében. Müvelődés LVIII. november-december

Forrás: http://www.muvelodes.ro/index.php/Cikk?id=157 (Letöltés: 2015.05.26.)

FORRAY R. K. - KOZMA T. 1992: Társadalmi tér és oktatási rendszer. Akadémiai Kiadó, Budapest. 177 p.

GAL, S. 1991: Mi a nyelvcsere és hogyan történik? - Regio - Kisebbségtudományi Szemle 2. 1. pp. 66-76.

GAL, S. - WoOlard, K. 1995: Constructing Languages and Publics: Authority and Representation. Pragmatics, 5.2. pp.129-138.

GÁBRITY MOLNÁR I. 2002: A fiatal értelmiségképzés lehetőségei. - In: GÁBRITY MOLNÁR I. MIRNICS Zs. (szerk.): Holnaplátók. Magyarságkutató Tudományos Társaság, Szabadka. pp. 1339.

GÁBRITY MOLNÁR I. 2005a: Mit értünk szórvány magyarság alatt Vajdaságban? - Létünk, 35.3. pp. 1931.

GÁBRITY MOLNÁR I. 2005b: Vajdasági egyházak, vallásgyakorlási nehézségek. - In: GÁBRITY MOLNÁR I.- MIRNICS ZS. (szerk.): Közérzeti barangoló. Magyarságkutató Tudományos Társaság, Szabadka. pp. 91-106.

GÁBRITY MOLNÁR I. 2006: Szerbia és Vajdaság demográfiai mutatói - migrációk. - In: GÁBRITY MOLNÁR I. - RICZ A. (szerk.): Kistérségek életereje - Délvidéki fejlesztési lehetőségek. Regionális Tudományi Társaság, Szabadka. pp. 57-72.

GÁBRITY MOLNÁR I. 2007: Vajdasági magyar fiatal diplomások karrierje, migrációja, felnőttoktatási igényei. - In: Karrierutak vagy parkolópályák? - Friss diplomások karrierje, migrációs tendenciája, felnőttképzési igényei a Kárpát-medencében. Kutatási zárójelentés. MTA Etnikainemzeti Kisebbségkutató Intézet Fórum Kisebbségkutató Intézet - Max Weber Társadalomtudományi Központ - Beregszászi Magyar Főiskola - Vajdasági Magyarságkutató Tudományos Társaság. pp. 132-172.

Forrás: http://gabritymolnariren.com/karrierutak.pdf (letöltési idő: 2014.05.010.)

GÁBRITY MOLNÁR I. 2008: Oktatásunk látlelete. Oktatásszociológiai olvasmány, Forum Könyvkiadó, Újvidék. 196 p.

GÁBRITY MOLNÁR I. 2011: Szociológiai jelenségvizsgálatok a Vajdaságban. Magyar Tannyelvü Tanítóképző Kar, Szabadka. 176 p.

GÁBRITY MOLNÁR I. 2015: A vajdasági magyarok helyzete és jövőképe. Forrás: http://confessio.reformatus.hu/a-vajdasagi-magyarok-helyzete-es-jovokepe\#page2 (Letöltési idő: 2016.05.20.) 
GEREBEN F. 1999: Identitás, kultúra, kisebbség. Osiris - MTA Kisebbségkutató Mühely, Budapest. $278 \mathrm{p}$.

GEREBEN F. 2007: A határon túli magyarok kulturális identitása (Különös tekintettel a tömb- és szórványmagyarságra). - Pro Minoritate, 2007 (tavasz). pp. 24-38.

Forrás:http://www.prominoritate.hu/folyoiratok/2007/ProMino07-1-04-Gereben.pdf (Letöltési idő: 2016.11.16.)

Golubović, P. - MARKOviĆ KRSTIĆ, S. 2006: Kretanje stanovništva Vojvodine tokom XX i početkom XXI veka. - Zbornik Matice Srpske za društvene nauke, 121. pp. 39-48.

GomBos G. 2010: Oktatás egy soknyelvü világban. Az oktatókat és az oktatási rendszert érintő kihívások. Iskolakultúra, 20.4. pp. 59-67.

GÖNCZ L. 1985: A kétnyelvűség pszichológiája. A magyar-szerbhorvát kétnyelvüség lélektani vizsgálata. Forum, Újvidék. 225 p.

GÖNCZ L. 1995: A tannyelv hatása a tanulók személyiségfejlődésére többnyelvü környezetben. - In: KASSAI I. (szerk.): Kétnyelvüség és magyar nyelvhasználat. MTA Nyelvtudományi Intézet, Budapest. pp. 65-81.

GÖNCZ L. 2004: A vajdasági magyarság kétnyelvüsége. Nyelvpszichológiai vonatkozások. MTT Könyvtár, Szabadka. 317 p.

GÖNCZ L. 2006: Iskolaválasztás Vajdaságban. - In: GÁBRITY MOLNÁR I. - MIRNICS Zs. (szerk.): Oktatási oknyomozó. Magyarságkutató Tudományos Társaság, Szabadka. pp. 125-141.

GÖNCZ, L. 2014: Maintenance of languages and cultures of indigeneous communities in CentralEastern-Europe through education: psycholinguistic and sociolinguistic perspectives. - In: SzALMA, J. (ed.): Strateški pravci razvoja društvenih nauka, kultura i umetnosti u Vojvodini do 2020. Godine. Zbornik radova-2014. Vojvodanska Akademija Nauka i Umetnosti, Novi Sad. pp. 56-80.

GROSJEAN, F. 1982: Life with two languages: An introduction to Bilingualism. Harvard University Press, Cambridge. 370 p.

GuILLEMETTE, Y. 2007: Breaking down monopolies. Expanding choice and competition in education. C.D Howe Institute Backgrounder, 105 (October)

Forrás:https://www.cdhowe.org/sites/default/files/attachments/research_papers/mixed/backgroun der_105.pdf (letöltve: 2015.02.10.)

GYÉMÁNT R. 2008: A határon túli magyarság demográfiai és társadalomstatisztikai sajátosságai. Doktori értekezés, Szegedi Tudományegyetem, Állam- és Jogtudományi Kar. 311 p.

GYÖRI SZABÓ R. 1999: Kisebbségi oktatási rendszerek a példaértékü kisebbségpolitikai gyakorlatú európai államokban - Finnországban és Olaszországban. - Magyar kisebbség: Nemzetpolitikai Szemle, 5.4.

Forrás:http://www.jakabffy.ro/magyarkisebbseg/index.php?action=cimek\&lapid=13\&cikk=m990 427.html (Letöltve: 2017.03.03).

GYURGYíK L. 2006: Népszámlálás 2001. A szlovákiai magyarság demográfiai-, település- és társadalomszerkezetének változásai az 1990-es években. Kalligram, Pozsony. 232 p.

GYURGYíK L. - HoRVÁTH I. - KISS T. 2010: Demográfiai folyamatok, etnikai és társadalmi reprodukció. - In: BITSKEY B. (szerk.): Határon túli magyarság a 21. században. Köztársasági Elnöki Hivatal, Budapest. pp. 69-124.

HABILCSEK L. 2004: A Kárpát-medencei magyarság demográfiai helyzete és előreszámítása 1991-től 2021-re. Bevezetés. - In: HABLICSEK L. - TóTH PÁL P. - VERES V. (szerk.): A Kárpát-medencei magyarság demográfiai helyzete és előreszámítása, 1991-2021. Központi Statisztikai Hivatal Népességtudományi Kutatóintézetének jelentései 78. KSH Népességtudományi Kutató Intézet, Budapest. pp. 25-27.

HAGGETT, P. 2006: Geográfia - Globális szintézis. Typotex Kiadó, Budapest. p. 213.

HAJDÚ Z. - SZÜGYI É. 2015: Szerbia. - In: HORVÁTH GY. (szerk.): Kelet- és Közép-Európa régióinak portréi. Kossuth Kiadó, Budapest. pp. 385-408. 
HAJNAL V. 2003a: „Mint leveleket a vihar” - Egy kétnyelvü vajdasági falu. - In: BAKÓ B. (szerk.): Lokális világok. Együttélés a Kárpát-medencében. MTA Társadalomkutató Központ, Budapest. pp. 283-317.

HAJNAL V. 2003b: Nyelv és kultúra egy szerémségi magyar szórványközösség életében. - In: GÁBRITYNÉ MOLNÁR I. - MIRNICS Zs. (szerk.): Kisebbségi létjelentségek. Szórvány- és szociolingvisztikai kutatások. Magyarságkutató Tudományos Társaság, Szabadka. pp. 85-117.

HAJNAL V. - PAPP R. 2004: „A mi kávénk”. Kulturális határok és mentalitáskategóriák három délvidéki magyar közösség kulturális gyakorlatában. - In: KovÁCS N. - OSVÁT A. - SZARKA L. (szerk.): Tér és terep. Tanulmányok az etnicitás és az identitás kérdésköréböl III. Akadémiai Kiadó, Budapest. pp. 99-118.

HAJNAL V. - PAPP R. 2005: „Nekem úgy szmétál, ha valaki úgy keverten beszél.” Egy Szerémségben élő magyar közösség kulturális antropológiai kutatásának tanulságai. - In: ILYÉS Z. - PAPP R. (szerk.): Tanulmányok a szórványról. Magyar Világok 2. Gondolat - MTA Etnikai-Nemzeti Kisebbségkutató Intézet, Budapest. pp. 52-63.

HAJNAL V. - PAPP R. 2007: „Én pravoszláv katolikus vagyok.” Vallás és identitás egy szerémségi magyar szórványközösség kultúrájában. - In: BALOGH B. - BODÓ B. -ILYÉS Z. (szerk.): Regionális identitás, közösségépítés, szórványgondozás. Lucidus Kiadó, Budapest. pp. 112-130.

HAJNAL V. - PAPP R. 2008: Közelből is távol: Magyar világok a Vajdaságban. Timp Kiadó Vajdasági Magyar Mủvelődési Intézet, Budapest-Zenta. 159 p.

HALÁSZ G. 2001: Az oktatási rendszer. Müszaki Tankönyvkiadó, Budapest. 216 p.

HECKMANN, F. 2008: Education and Migration. Strategies for integrating migrant children in European schools and societies. A synthesis of research findings for policy-makers. European Comission.

Forrás:http://www.nesse.fr/nesse/activities/reports/activities/reports/education-and-migration-pdf (Letöltési idő: 2015.08.15.)

HÍRES-LÁSZLÓ K. 2016: Új stratégiák? Módosulnak a tannyelv-választási szokások Kárpátalján? - In: HíRES-LÁsZló K. (szerk.): Nyelvhasználat, kétnyelvűség. Tanulmányok a Hodinka Antal Nyelvészeti Kutatóközpont kutatásaiból II. II. Rákóczi Ferenc Kárpátaljai Magyar Főiskola, Hodinka Antal Nyelvészeti Kutatóközpont. Autdor-Shark, Ungvár. pp. 119-136.

HORVÁTH I. 2006: Kisebbségszociológia. Alapfogalmak és kritikai perspektívák. Kolozsvári Egyetemi Kiadó, Kolozsvár. 182 p.

HUSZKA B. - BAKÓ T. 2007: Észak-Vajdaság magyar többségü községeinek gazdasága. Mủhelytanulmány 24. Európai Összehasonlító Kisebbségkutatások Közalapítvány, Budapest. 116 p.

HUSZKA B. 2008: Szerbia decentralizációja: a kisebbségi dimenzió. Európai Összehasonlító Kisebbségkutatások Közalapítvány, Budapest. 197 p.

ILYÉS Z. 2004: A határfogalom változó tartalmai a geográfiától az empirikus kultúrakutatásig. - In: KovÁCS N. - OsvÁT A. - SzARKA L. (szerk.): Tér és terep: Tanulmányok az etnicitás és az identitás kérdésköréből. Az MTA Kisebbségkutató Intézetének évkönyve 3. Akadémiai Kiadó, Budapest. pp. 9-16.

ILYÉS Z. 2005a: Szórványkutatás, szórványértelmezés. Megjegyzések a Kárpát-medence szórványközösségeinek társadalomtudományos vizsgálatához. - In: ILYÉS Z. - PAPP R. (szerk.): Tanulmányok a szórványról. Gondolat - MTA Etnikai - Nemzeti Kisebbségkutató Intézet, Budapest. pp. 64-78.

ILYÉS Z. 2005b: Szórványkutatás, Szórványértelmezés. Megjegyzések a Kárpát-medence szórványközösségeinek társadalomtudományi vizsgálatához. - Magyar Tudomány 50.2. pp. 145155.

ILYÉS, Z. 2007: Researching and interpreting diaspora - Remarks on social science research into the diaspora communities of the Carpathian Basin. - In: BALOGH, B. - ILYÉS, Z. (ed.): Perspectives of Diaspora Existence: Hungarian Diasporas in the Carpathian Basin - Historical and Current Contexts of a Specific Diaspora Interpretation and Its Aspects of Ethnic Minority Protection Akadémiai Kiadó, Budapest. pp. 47-65. 
ILYÉS Z. 2008: Mezsgyevilágok: etnikus interferenciák és nemzeti affinitások térbeli mintázatai a Kárpát-medencében. Lucidus, Budapest. 199 p.

ILYÉS Z. 2011: Szórványhelyzetben a Kárpát-medencében: Háttértanulmány a Határon Túli Magyar Oktatásért Apáczai Közalapítvány számára. E-publikáció.

Forrás:http://www.szorvany.hu/_userfiles/olvasnivalok/ilyes_zoltan_szorvanyhelyzetben_a_karpa tmedenceben.pdf (Letöltés időpontja: 2016.11.04.)

IZSÁK É. 2002: Az állam klasszikus politikai földrajzi értelmezése. - In: BERNEK Á. (szerk.): A globális világ politikai földrajza. Nemzeti Tankönyvkiadó, Budapest. pp. 68-80.

JoÓ HorTi L. - MENGYÁn PletiKoszITY I.- CSERNIK I. - BADIS R. 2014: Magyar gyerek, szerb iskola, avagy a magyar oktatás vonzereje a Vajdaságban. - Kisebbségkutatás 23. 4. pp. 174-187.

KAPITÁNY B. 2013: Kárpát-medencei népszámlálási körkép. - Demográfia 56.1. pp. 25-64.

KEMÉNYFI R. 2005: A többrétegü „szórvány” kifejezés a kisebbségkutatásban. - In: ILYÉS Z.-PAPP R. (szerk.): Tanulmányok a szórványról. Gondolat - MTA Kisebbségkutató Intézet, Budapest. pp. 78-90.

Forrás:http://www.mtaki.hu/docs/tanulmanyok_a_szorvanyrol/szorvany_kemenyfi_robert_tobbre tegu_szorvany.pdf (Letöltési idő: 2014.09.14.)

KICOŠEV, S. - KOCSIS K. 1998: A menekültügy társadalmi-demográfiai aspektusai Vajdaságban. Regio - Kisbbségtudományi szemle 9.3. pp. 63-74.

KISS J. 1995: Társadalom és nyelvhasználat. Szociolingvisztikai alapfogalmak. Nemzeti Tankönyvkiadó, Budapest. 318 p.

KISS T. - BARNA G. 2014: Népszámlálás 2011. Erdélyi magyar népesedés a XXI. század első évtizedében. Nemzeti Kisebbségkutató Intézet, Kolozsvár. 78 p.

KINCSES Á. 2012: Szerb állampolgárok Magyarországon - Helyzetkép. - In: KINCSES Á. (szerk.): Szerb állampolgárok Magyarországon. Európai Integrációs Alap, Budapest. pp. 14-39.

Kocsis K. - Kocsis-HodOSI E. 1998: Ethnic Geography of the Hungarian Minorities in the Charpatian Basin. Geographical Research Institute, Research Centre for Earth Science and and Minority Studies Programme, Hungarian Academy of Science, Budapest. 241 p.

Kocsis K. 2002: Etnikai földrajz. - In: TóTH J. (szerk): Általános Társadalomföldrajz I. Dialóg Campus Kiadó, Budapest - Pécs. pp. 313-335.

KOCSIS K.- BOTTLIK ZS. - TÁTRAI P. 2006: Etnikai térfolyamatok a Kárpát-medence határainkon túli régióiban (1989-2002). MTA Földrajztudományi Kutatóintézet, Budapest. 197. p.

Kocsis K. - TÁtrai P. - AgÁRdi N. - BAlizs D. - Kovács A. 2015: A Kárpát-Pannon-térség változó etnikai arculata a 15. század végétől a 21. század elejéig. Térképmagyarázó. - In: KoCSIS K. - TÁTRAI P. (szek.): A Kárpát-Pannon-térség változó etnikai arculata. MTA CSFK Földrajztudományi Intézet, Budapest. 35 p.

KONTRA M. 2005: Mi a lingvicizmus és mit lehet ellene tenni? - In: GÁBRITY MOLNÁR I. - MIRNICS ZS. (szerk.): Közérzeti barangoló (Műhely- és előadás-tanulmányok). Magyarságkutató Tudományos Társaság, Szabadka. pp.175-202.

KORHECZ T. 2009: A hivatalos nyelvhasználat jogi keretei a Vajdaságban - Szerbiában. - Jog és gyakorlat. A Magyar Tudományos Akadémia folyóirata 170.1. pp. 1313-1321.

KOVAČEVIĆ, T. - KICOŠEV, S. 2007: Influence of Global Changes on Micro European Regions, on the Example of Vojvodina. Third International Conference, Sofia University „St. Kliment Ohridski“, Faculty of Geology and Geography, Sofia. pp. 305-309.

KovÁCS A. D. 2015: Megújulási lehetőségek és gátló tényezők a szerb-magyar határ menti térségben. - In: RiCZ A. - TAKÁCS Z. (szerk.): A régió TÍZpróbája. Regionális Tudományi Társaság, Szabadka. pp. 89-99.

KovÁCs Z. 2015: Népesség- és településföldrajz. ELTE Eötvös Kiadó, Budapest. 239 p.

KovÁCS Z. 2017: Társadalom-földrajz: bevezetés. - Magyar Tudomány 178.3. pp. 258-260.

Forrás: http://www.matud.iif.hu/2017/03/01.htm (letöltve: 2017.07.03)

KovaČEviĆ, T. - ZAKIĆ, L. - BUBALO-ZivkOviĆ, M. 2010. Age-gender strukture of Croats in Vojvodina Province. - Journal of Studies and Research in Human Geography 4.2. pp. 63-78. 
KozMA T. 2003: Kisebbségi oktatás Közép-Európában. Oktatáskutató Intézet, Budapest. 80 p.

KozMA T. 2005: Kisebbségi oktatás Közép-Európában. Új Mandátum Kiadó, Budapest. 195 p.

KUGLER J. 2007: Vajdaság településhálózatának sajátosságai. - In: NAGY I. (szerk.): Vajdaság. Dialóg Campus Kiadó, Pécs-Budapest. pp. 225-250.

LADOS G. - HEGEDŰS G. - KOVÁCS Z. - BOROS L. 2015: Oda és vissza - Az elvándorlás hatásainak és a visszavonzás lehetőségeinek értékelése hazánkban. - In: FÁBIÁN A. - BERTALAN L. (szerk.): Otthon a Kárpát-medencében: Területfejlesztési Szabadegyetem 2011-2015. Nyugatmagyarországi Egyetem Kiadó, Sopron. pp.115-136.

LAPONCE, J. 1987: Languages and their territories. University of Toronto Press, Toronto. 265 p.

LANSTYÁK I. 1994: Az anyanyelv és a többségi nyelv oktatása a kisebbségi kétnyelvüség körülményei között. - Regio - Kisebbség, politika, társadalom 5.4. pp. 90-116.

LANSTYÁK I. - SZABÓMIHÁLY G. 2002: Magyar nyelvtervezés Szlovákiában. Kalligram Könyvkiadó, Pozsony. 303 p.

LÉPHAFT, Á. -NÉMETH, Á. - REMÉNYI, P. 2014: Ethnic diversity and polarization in Vojvodina. Hungarian Geographical Bulletin 63.2. pp. 135-157.

LÁNCOS P. L. 2012: Nyelvpolitika és nyelvi sokszínúség az Európai Unióban. Doktori értekezés. Pázmány Péter Katolikus Egyetem, Jog - és Államtudományi Doktori Iskola. 295 p.

MACNAMARA, J. 1967: The bilingual's linguistic performance - A psychological overview. - Journal of Social Issues 23.2. pp. 58-77.

MAlmberg, B. - Andersson, E. - Bergsten, Z. 2013: School Choice Motives: The Effects of Class and Residential Context. Working Paper http://www.su.se/polopoly_fs/1.156150.1384943996!/menu/standard/file/WP_2013_11.pdf (Letöltési idő: 2018.03.15)

MARIÁN B. - SZABÓ I. 2003: A kisebbségi oktatás intézményi környezete Magyarországon. - Regio 14.3. pp.149-218.

MÁRTON J. 2013: Többségi nyelvü iskolaválasztás székelyföldi magyar nemzetiségü diákok körében. - Kisebbségkutatás 22.4. pp.18-30.

MÉSZÁROS R. 2014: Az interdiszciplinaritás néhány földrajzi összefüggése. - Földrajzi Közlemények 138.4. pp. 335-340.

MCDONOUGH, P. M. -FAnN, A. J. 2007: The Study of Inequality. - In: GuMPORT, P. (ed.) Sociology of Higher Education. Contri-butions and Their Contexts. The John Hopkins University Press, Baltimore. pp. 53-93.

M.CSÁSZÁR ZS. 2011: Kisebbség-oktatás-politika a Balkánon. Közép-Európai monográfiák 2. Egyesület Közép-Európa Kutatására, Szeged. 160 p.

MiLOVANOVIĆ, Z. 2006: Starosna struktura stanovništva Vojvodine prema teritorijalnoj i nacionalnoj pripadnosti.

Forrás:http://www.doiserbia.nb.rs/img/doi/0352-5732/2006/035257320621305M.pdf (Letöltési idő: 2016.09.10)

MIRNICS K. 1994: Kétnyelvűség a vajdasági vegyes házasságokban. - Regio - kisebbség politika, társadalom 5.4. pp. 117-127.

MIRNICS K. (2003): Nemzeti kisebbségből szórványnépesség. - In: GÁBRITYNÉ MOLNÁR I. - MIRNICS Zs. (szerk.): Kisebbségi létjelentségek. Szórvány- és szociolingvisztikai kutatások. Magyarságkutató Tudományos Társaság, Szabadka. pp. 25-84.

MOLNÁR CSIKÓS L. 1989: A magyar nyelv helyzete Jugoszláviában. - Magyar Nyelvőr, 113.2. pp. $162-175$.

MOLNÁR J. - MOLNÁR D. I. 2005: Kárpátalja népessége és magyarsága a népszámlálási és népmozgalmi adatok tükrében. Kárpátaljai Magyar Pedagógusszövetség, Beregszász. 115 p.

MORVAI T.- SZARKA L. 2012: A magyar tannyelvű iskolák választása Dél-Szlovákiában. Kisebbségkutatás 21.3. pp. 536-567.

MORVAI T. 2013: „Duplán teljesít.” Iskolaválasztás Zoborvidéken. - Kisebbségkutatás 22.4. pp. 6073. 
NAGY I. 2006: A vajdasági elitmigráció sajátossága. - Létünk, 36.2. pp.111-122.

NAGY I. - KICOŠEV, S. - DÖVÉNYI Z. - LÉPHAFT Á. 2012: Vajdaság. - In: DöVÉNYI Z. (szerk.): A Kárpát-medence földrajza. Akadémiai Kiadó, Budapest. pp. 1130-1178.

NAGY I. 2015: Szerbia térszerkezeti felosztása és annak tükröződése az egyetemi hallgatók mentális térképében. - In: HARDI T. (szerk.): Terek és tér-képzetek: Elképzelt és formalizált terek, régiók a Kárpát-medencében, Közép-Európában. Fórum Kisebbségkutató Intézet - MTA KRTK Regionális Kutatások Intézete, Somorja- Győr. pp. 303-320.

OgBU, J.U. 1978: Minority Education and Caste: The American System in Cross-Cultural Perspective. Academic Press, New York. 410 p.

OGBU, J. 1981: Origins of human competence. A cultural-ecological perspective. - Child Development 52.2. pp. 413-429.

OGBU, J.U. 1993: Variability in Minority School Performance: A Problem in Search of an Explanation. - In: JACOB, E. - HORDAN, C.J. (eds.): Minority Education: Anthropological Perspectives. NJ: Ablex. Norwood. pp. 83-111.

OGBU, J.U. 1997: Understanding the School Performance of Urban Blacks: Some Essential Background Knowledge. - In: WALBER, H.J. - REYES, O. - WEISSBERG, R.P. (eds.): Children and Youth: Interdisciplinary Perspectives. SAGE, London. pp. 190-221.

PAPP Z. A. 2012a: Az iskolaválasztás motivációi és kisebbségi perspektívái. - Kisebbségkutatás 21.3. pp. 399-417.

PAPP Z. A. 2012b: Kisebbségi magyarok oktatási részvételének értelmezési lehetőségei. - Educatio 21.1. pp. 3-23.

PAPP Z. A. 2013: Többségi nyelvü iskolaválasztás kisebbségben, avagy a PISA - adatoktól a Kárpátmedencei diskurzusokig. - Kisebbségkutatás 22.4. pp. 7-17.

PAPP Z. A. 2014a: A kisebbségi oktatás lehetséges magyarázatai és fejlesztési irányai. - In: DIósZEGI L. (szerk.): Kárpátalja magyar nyelvű oktatásának jelen és jövője. Teleki László Alapítvány, Budapest. pp.17-34.

PAPP Z. A. 2014b: Selecting a Majority-Language School by Hungarian Minority Students, or From PISA Results to Discourses in the Carpathian Basin. Minority Studies: demography, minority education, ethnopolitics, 17. pp. 89-101.

Forrás:http://real.mtak.hu/19903/1/papp_z_a_tobbsegi_nyelvu_iskolavalasztas_forditani_hu_en2 _pza_is.pdf (Letöltési idő: 2016.01.21.)

PAPP Z. A. 2016: Változatok erdélyi szórványoktatásra. - Regio 24.4. pp. 173-195.

PÁSZTOR A. 2006: Öshonos kisebbség mint nem önkéntes kisebbség: Ogbu kulturális-ökológiai elméletének tesztelése Európában. - Szociológiai Szemle 16.2. pp. 3-36.

PENEV, G. 2006: Vojvođanske migracije tokom 1990-ih godina: više doseljenih, manje odseljenih. Centar za demografska istraživanja, Institut društvenih nauka Beograd. Forrás:http://www.doiserbia.nb.rs/img/doi/0352-5732/2006/0352-57320621077P.pdf

(Letöltve: 2016.09.14.)

PRIESTLY, T. 1994: Effects of educational and social mobility on language maintenance, language attitudes and language structure: The case of Sele in Carinthia. - Journal of Multilingual and Multicultural Development 15.2-3. pp. 199-217.

PUSKÁS T. 2000: Nyelv, identitás és nyelvpolitika Európában. - Fórum: Társadalomtudományi szemle 2.1. pp. 69-84.

Forrás: http://www.epa.uz.ua/00000/00033/00003/puskas.htm (letöltve:2017.03.10.)

PUSKÁS T. 2003: Magyarnak lenni kisebbségben és szórványban. - Fórum: Társadalomtudományi szemle 6.4. pp. 104-124.

Forrás:http://epa.oszk.hu/00000/00033/00015/szemle_2003_4_agora.htm (Letöltési idő: 2017.03.10.)

RADÓ P. 1996: Asszimiláció és nyelvváltás a magyarországi szlovének körében. - Regio - kisebbség, politika, társadalom 7.1. pp. 142-170.

RÁCZ L. 2008: A szerbiai oktatási rendszer finanszírozása és néhány kisebbségi vonatkozása. - Regio, 19.2. pp. 188-209. 
SEBŐK L. 2005: A szlavóniai magyar szórványok. - In: BAKÓ B. - SzOTÁK Sz. (szerk.): Magyarlakta kistérségek és kisebbségi identitások a Kárpát-medencében. Gondolat - MTA Etnikai-nemzeti Kisebbségkutató Intézet, Budapest. pp. 179-191.

SÉRA M. 2013: Magyarok a szórványban a többségi oktatásban: (interjúzás tapasztalatai Beregrákoson). - Kisebbségkutatás 22.4. pp. 122-136.

SZERBHORVÁTH GY. 2015: A kisebbségi nyelvi jogok Vajdaságban - jog és valóság. - Pro Minoritate, 2015 (ösz). pp. 69-94.

Forrás:http://www.prominoritate.hu/folyoiratok/2015/ProMino-1503-05-Szerbhorvath.pdf

(Letöltési idő: 2016.10.25.)

SkUtNaBb-KangaS, T. 1981: Bilingualism or Not: The Education of Minorities. Avon Multilingual Matters Ltd., Clevedon. 378 p.

SKUTNABB-KANGAS, T. 1997: Nyelv, oktatás és a kisebbségek. Teleki László Alapítvány, Budapest. $93 \mathrm{p}$.

SKUTNABB-KANGAS, T. 1994: A kisebbségi oktatás fejlődésének szakaszai. - Regio 5.3. pp. 3-18.

SPICER, E. H. 1968: Acculturation. - In: SILLS, D.L. (e.d): International Encyclopedia of the Social Sciences. Macmillan and the Free Press, New York. pp. 21-27.

SZILÁGYI N. S. 1997: A szórványmagyarság: probléma vagy ürügy

Forrás:http://docplayer.hu/21940170-A-szorvanymagyarsag-problema-vagy-urugy.html (Letöltési idő: 2016.10.05.)

SZLÁVITY Á. 2008: Az észak-bácskai régió munkaerö-piaci tendenciái. - In: GÁBRITY MOLNÁR I. MIRNICS ZS. (szerk.): Regionális erőnlét. A humánerőforrás befolyása Vajdaságban. Magyarságkutató Tudományos Társaság, Szabadka. pp. 246-265.

SZLÁviTY Á. 2007: Népesség és munkaerőpiac. - In: NAGY I. (szerk.): Vajdaság. Dialóg Campus Kiadó, Pécs-Budapest. pp. 188-223.

SCHNEIDER, M. - BUCKLEY, J. 2002: What do parents want from schools? Evidence from the Internet. - Educational Evaluation and Policy Analysis 24.2. pp. 13-3144.

SzOTÁK Sz. 2013: Elöszó. - In: KöTÉL E. - SzOTÁK Sz.(szerk.): Hagyomány és jövőkép: Anyanyelv(ek), oktatáspolitikai stratégiák, karrierkövetés. Határhelyzetek IV. Balassi Intézet Márton Áron Szakkollégium, Budapest. pp. 7-8.

SZÜGYI É. 2010: A vajdasági fiatalok kar- és szakválasztását befolyásoló tényezők szerbiai/magyarországi diplomások és hallgatók körében. - In: FÁBRI I.-KÖTÉL E. (szerk.) Határhelyzetek III. Önmegvalósítási kísérletek: hagyományőrzéstől a nyelvi identitásig. Balassi Intézet Márton Áron Szakkollégium, Budapest. pp. 259-289.

SZÜGYI É. - TAKÁCS Z. 2011: Menni vagy maradni? Esélylatolgatás szerbiai és magyarországi diplomával a Vajdaságban. - In: PÁGER B. (szerk.): Évkönyv 2011. PTE Közgazdaságtudományi Kar Regionális Politika és Gazdaságtan Doktori Iskola, Pécs. pp. 283-300.

SZÜGYIÉ. 2012: Iskolaválasztás a Délvidéken. - Kisebbségkutatás 21.3. pp. 514-535.

SZÜGYI É. 2013: Délvidéki magyarok a többségi tannyelvü oktatásban. - Kisebbségkutatás 22.4. pp. 74-86.

SZÜGYIÉ.- TROMBITÁs T. 2013: A vajdasági magyarok oktatási helyzete Szerbiában. - In: GALLIK, J. - Rigó, Gy. - Kralina Hoboth, K. - VARGOVÁ, Z. (szerk): Science for Education - Education for Scine. Tudomány az oktatásért - Oktatás a Tudományért. Közép-európai Tanulmányok Kara, Konstantin Filozófus Egyetem, Nyitra. pp. 101-112.

SZÜGYI É. 2014: Többségi iskolaválasztási stratégiák a vajdasági tömbmagyarság körében. - In. TAKÁCS Z.- RICZ A. (szerk.): Regionális kaleidoszkóp. Regionális Tudományi Társaság, Szabadka. pp. 199-210.

Petitto, L. A. - Katerelos, M. - Levy, B.G. - GaunA, K. (2001): Bilingual signed and spoken language acquesition from birth: implications for the mechanism underlying early bilingual language acquisition. - Journal of Child Language 28.2. pp. 453-496.

PÉNTEK J. 2000: Látlelet a szórványhelyzet nyelvi következményeiről. Erdélyi Múzeum, 2000.3-4. pp. 287-290. 
Forrás: http://www.epa.hu/00900/00979/00020/m05pentek.htm

(Letöltési idő: 2012.09.12.)

ProbÁld F. 2007: Szerbia. - In: PROBÁld F. - SzABÓ P. (szerk.): Európa regionális földrajza. Társadalomföldrajz. ELTE Eötvös Kiadó, Budapest. pp. 439-444.

RAVASZ Á. 2013: Tartós döntések: iskolaválasztás Dunaszerdahelyen. - Kisebbségkutatás 22.4. pp. 49-59.

SORBÁN A. - DOBOS F. 1997: Szociológiai felmérés a határon túli magyar közösségek körében az asszimiláció folyamatairól. (I.) Iskolaválasztás és anyanyelvhasználat. - Magyar Kisebbség 1997.3-4. pp. 293-323.

Forrás: http://www.hhrf.org/magyarkisebbseg/9703/m970323.htm

(Letöltési idő: 2012.06.10.)

SORBÁN A. 2000: Tanuljon románul a gyermek, hogy jobban érvényesülhessen. Az asszimiláció természetrajzához. - Magyar Kisebbség 6.3. pp. 167-180.

Forrás:http://www.jakabffy.ro/magyarkisebbseg/index.php?action=cimek\&lapid=16\&cikk=m000 311.html (Letöltési idő: 2013.05.24.)

TAKÁCS I. 2011: Vajdasági magyar anyanyelvü diákok környezetnyelvhez és idegen nyelvhez való viszonyulása. - Alkalmazott Nyelvészeti Közlemények 6.1. pp. 215-231.

TAKÁCS Z. 2008: A munkaerö-kompetencia és az oktatás viszonya. - In: GÁBRITY MOLNÁR I.MIRNICS Zs. (szerk.): Regionális erőnlét. A humánerőforrás befolyása Vajdaságban. Magyarságkutató Tudományos Társaság, Szabadka. pp. 267-293.

TAKÁCS Z. 2009: Oktatási intézetek tudástranszfer hatásának vizsgálata Vajdaságban. - In: SOMOGYI S. (szerk.): Évkönyv, 2008. Regionális Tudományi Társaság, Szabadka. p. 214.

TAKÁCS Z. - TÁTRAI P. - ERÖSS Â. 2013: A Vajdaságból Magyarországra irányuló tanulmányi célú migráció. - Tér és Társadalom 27.2. pp. 77-95.

TAKÁCS Z. - TÁTRAI P. - ERÖSS Á. - FILEP B. - RISTIĆ, D. 2014: Tanulmányi célú migráció: A vajdasági hallgatók esete. - In. TAKÁCS Z.- RICZ A. (szerk.): Regionális kaleidoszkóp. Regionális Tudományi Társaság, Szabadka. pp. 279-289.

TÁTRAi P. - KOCSIS K. - GÁBRITY MOLNÁR I. - TAKÁCS Z. 2013: A Vajdaságot érintő migráció és annak történeti előzményei. -Tér és Társadalom 27.2. pp. 35-54

TÁTRAI P. 2017a: Egy szórványközösség nyelvi és társadalmi jellemzöinek elemzése. - Jel-Kép: Kommunikáció Közvélemény Média, 2017/2.

Forrás:http://communicatio.hu/jelkep/2017/2/JelKep_2017_2_Tatrai_Patrik.pdf (Letöltési idő:2017.09.27)

TÁTRAI P. 2017b: A Kárpát-medencei magyar szórványok településszerkezete és főbb demográfiai jellemzői. - Kisebbségi Szemle 2.1. pp. 7-34.

TÓTH-GLEMBA K. 2005: A szórványmagyarság igényeinek szakterületek szerinti feltárása. - Létünk 35.3. pp. 37-49.

TóTH PÁL P. 2005: Szórvány/diaszpóra. - In: ILYÉs Z. - PAPP R. (szerk.): Tanulmányok a szórványról. Gondolat Kiadó, MTA Etnikai-nemzeti Kisebbségkutató Intézet, Budapest. pp. 108-114.

TÍMÁR J. 2001: A modern társadalomföldrajz szemlélete és módszerei. Regionális Tudományi Tanulmányok 6. pp. 49-60.

TROMBITÁs T. 2013: Többségi nyelvű iskolaválasztás a vajdasági szórványban. - Kisebbségkutatás 22.4. pp. 87-97.

TROMBITÁs T. - SZÜGYi É. 2012: A falusi magyar tannyelvü iskolák Vajdaságban. - A falu 24.4. pp. 27-35.

TrombitÁs T. - SzÜGYI É. 2014: Az újvidéki magyar kisebbség iskolaválasztási jellemzői. - In: KONCZ I. - SzOVA I. (szerk.): „A Tudomány szolgálatában”. Professzorok az Európai Magyarországért Egyesület, Budapest. pp. 149-160.

VAJDA ZS. - KÓSA É. 2005: Neveléslélektan. Osiris Kiadó, Budapest. 564 p.

VÁMOS Á. 2017: Kétnyelvủ oktatás Magyarországon; tannyelvpolitika, tannyelvpedagógia. Doktori értekezés tézisei. 
Forrás:http://real-d.mtak.hu/984/1/dc_1309_16_tezisek.pdf (letöltés ideje: 2017.10.26)

VETÉSI L. 1999: Iskola a nyelvhatáron. - Korunk 10.10. pp. 9-21.

Forrás: http://www.epa.oszk.hu/00400/00458/00022/10k03.htm (letöltve: 2014.02.20.)

VETÉSI L. 2000: Szórványstratégia - nemzetstratégia. - Magyar Kisebbség 20.2. pp. 172-214.

YINGER, J. M. 2002: Az asszimiláció és a disszimiláció elmélete felé. - Regio - Kisebbség, politika, társadalom 13.1. pp. 24-44.

\section{Magyar Szó-közéleti napilap (Szerbia):}

Magyar Szó napilap, 2015.07.12.

Nagykikinda - Összetartással a magyar közösség megmaradásáért-

https://www.magyarszo.rs/hu/2764/hetvege/129956/Nagykikinda.htm

(Letöltöltési idő: 2016.10.09)

Magyar Szó napilap, 2016, LXXIII.évf.,203. (23 591.) szám

Újvidéken nőtt a magyar ajkú elsősök száma, Magyar Szó online, 2014.06.26.

http://www.magyarszo.com/hu/2412/kozelet_oktatas/114046/\%C3\%9Ajvid\%C3\%A9ken-

n\%C5\%91tt-a-magyar-ajk\%C3\%BA-els\%C5\%91s\%C3\%B6k-sz\%C3\%A1ma.htm

(Letöltési idő: 2014.09.26)

\section{Republički Zavod za Statistiku (Statistical Office of Serbia):}

Republički Zavod za Statistiku -RZS, 2011

Forrás: http://webrzs.stat.gov.rs/WebSite/Default.aspx

(Letöltési idő: 2015.03.10.)

Popis stanovništva 2002

Forrás: http://pod2.stat.gov.rs/ObjavljenePublikacije/G2002/pdf/G20024001.pdf

(Letöltési idő: 2016.04.27.)

Popis stanovništva 2011

Forrás:http://media.popis2011.stat.rs/2014/publikacije/Saopstenje_\%20Knjiga20_24april_srpski.pdf (Letöltési idő: 2016.04.27.)

Republički Zavod za Statistiku, Popis stanovništva, domađinstava i stanova 2011 u Republici Srbiji Stanovništvo: Nacionalna pripadnost- Population: Ethnicity (Knjiga 1)

Forrás:http://pod2.stat.gov.rs/ObjavljenePublikacije/Popis2011/Nacionalna\%20pripadnost-

Ethnicity.pdf

(Letöltési idő: 2015.03.12.)

Republički Zavod za Statistiku, Popis stanovništva, domađinstava i stanova 2011 u Republici Srbiji Stanovništvo:Veroispovest, maternji jezik i nacionalna pripadnost- Population: Religion, mother tongue and ethnicity (Knjiga 4)

Forrás: http://pod2.stat.gov.rs/ObjavljenePublikacije/Popis2011/Knjiga4_Veroispovest.pdf

(Letöltési idö: 2015.03.12.)

Republički Zavod za Statistiku -Uporedni pregled broja stanovnika,2011

Forrás: http://popis2011.stat.rs/?page_id=2162

(Letöltési idő: 2016.07.02.) 


\section{Felhasznált források és statisztikai adatbázisok}

EUMC (2006) Romák és travellerek a közoktatásban. Az EU tagállamaiban fennálló helyzet áttekintése. Összefoglaló.

Forrás: http://docplayer.hu/15011543-Romak-es-travellerek-a-kozoktatasban.html

(Letöltési idő: 2015.10.21).

Identitás Kisebbségkutató Mühely: A szórványban tevékenykedőkkel készített mélyinterjúk elemzése Forrás: http://www.idkm.org/hirek/Melyinterjuk_elemzese1.pdf

(Letöltési idő: 2017.09.10.)

Informacija o upisu učenika u prvi razred osnovne škole u AP Vojvodini u školskoj 2014/15 godini Forrás: http://www.puma.vojvodina.gov.rs/documents.php?st=1

(Letöltési idő: 2017.06.25.)

Észak-Bácskai Magyar Pedagógusok Egyesülete (Udruženje Prostvenih Radnika Mađara Severne Bačke)

http://www.tanar.org.rs

(Letöltési idő: 2017.07.04.)

Hídvégi Mikó Imre Kutatóintézet Alapítványának tanulmánya

Forrás: http://www.hidvegimiko.hu/b2_kutatasaink/Unios_palyazatok_SZERBIA.pdf,

(Letöltési idő: 2011.12.08.)

Magyar Nemzeti Tanács 2011: Oktatásfejlesztési stratégia megvalósítása egy év távlatából

Forrás: http://archiv.mnt.org.rs/985-Oktatasfejlesztesi-strategia-megvalositasa-egy-ev-tavlatabol-2011

(Letöltési idő: 2015.06.15.)

Népesedési akcióterv 2013-2017, Magyar Nemzeti Tanács

Forrás: http://www.mnt.org.rs/dokumentumok/strategiak/nepesedesi-akcioterv-2013-2017

(Letöltési idő: 2015.02.28.)

Oktatási helyzetkép: A Vajdasági Magyar Pedagógusok Egyesülete évi közgyülésén elfogadott zárónyilatkozat, 2016.11.11.

Forrás:http://www.vmpe.org.rs/Archivum/2017/figyelo/Oktat\%C3\%A1si\%20helyzetk\%C3\%A9p\%20 2016.pdf

(Letöltési idő: 2017.07.18)

Oktatásfejlesztési Stratégia 2010-2016, Magyar Nemzeti Tanács

http://www.profturchany.eu/documents/UIDD_hu_Vajdasagi_okt_fejl.pdf

(Letöltési idő: 2011.09.10)

Republika Srbija: Treći periodični izveštaj o primeni Evropske Povelje o regionalnim ili manjinskim jezicima u Rebuplici Srbiji, Beograd, decembar, 2014.

Forrás: http://www.ljudskaprava.gov.rs/sh/node/20001

(Letöltési idő: 2016.07.10)

Tanulmányok a határ menti régiók gazdasági és munkaerő-piaci helyzetéröl es lehetőségeiről, a foglalkoztatást segítő támogatásokról (szerb-magyar határrégió)

TÂMOP-1.3.1-07/1.-2008-0002 „Az Állami Foglalkoztatási Szolgálat fejlesztése az integrált munkaügyi és szociális rendszer részeként" c. kiemelt projekt, 3.6 alprojekt 
Forrás: http://www.afsz.hu/engine.aspx?page=afsz_tamop131_36alprojekt

(Letöltési idő: 2013.03.10)

Tartományi Oktatási Titkárság honlapja

http://www.obrazovanje.vojvodina.gov.rs/index.php?option=com_content\&view=article\&id=84\&Item id=43\&lang=hu

(Letöltési idő: 2013.02.10)

Vajdasági magyar kulturális stratégia 2012-2018, Magyar Nemzeti Tanács, 2011

http://www.eugenonline.com/download/kulturalisstrategia.pdf

(Letöltési idő: 2012.09.10)

Vajdasági magyar szórványstratégia 2011-2020. Identitás Kisebbségkutató Mühely, Zenta, 2011

http://www.idkm.org/hirek/Szorvany_strategia.pdf

(Letöltési idő: 2013.06.20.)

\section{Törvények:}

Zakon o osnovama sistema obrazovanja i vaspitanja=Sl. Gl. RS 62/03, 58/04, 58/04, i 62/04, Forrás: www.mp.gov.rs (Letöltési idő: 2011.12.01.)

Zakon o osnovama sistema obrazovanja i vaspitanja, "Sl. Glasnik RS", br. 88/2017 i 27/2018

Source: www.mp.gov.rs (Letöltési idő: 2018.02.01.)

Zakon o srednjem obrazovanju i vaspitanju,"Sl. glasnik RS", br. 50/92, 53/93, 67/93, 48/94, 24/96, 23/2002, 25/2002 - ispr., 62/2003 - dr. zakon, 64/2003 - ispr. dr. zakona, 101/2005 - dr. zakon i 72/2009 - dr. zakon), Forrás: www.mp.gov.rs (Letöltési idő: 2011.12.01.)

Zakon o srednjem obrazovanju i vaspitanju,"Sl. glasnik RS", br. 55/2013 i 101/2017

Source: www.mp.gov.rs (Letöltési idő: 2018.02.01.) 


\section{Köszönetnyilvánítás}

Köszönetemet szeretném kifejezni, Dr. Kovács Zoltánnak, a Szegedi Tudományegyetem Gazdaság-és Társadalomföldrajz Tanszék vezetőjének, aki lehetővé tette számomra a Tanszéken való tanulást és tudományos felkészülést, köszönöm sokoldalú támogatását.

Köszönetemet fejezem ki témavezetőmnek, Dr. Bajmócy Péternek az útmutató tanácsaiért, amelyek hozzájárultak disszertációm elkészítéséhez, illetve köszönöm a kutatás ideje alatt, és az értekezés megírása során nyújtott folyamatos szakmai ajánlásait.

Szeretném megköszönni Dr. Boros Lajos tanár úr segítségét, aki hasznos észrevételivel és értékes tanácsaival gazdagította munkám. Mindemellett köszönöm, hogy saját doktorandusz hallgatói mellett időt szakított, a kutatás és a disszertáció megírása során felmerült kérdéseim megválaszolására.

Köszönet illeti Dr. Mészáros Rezső akadémikus urat, aki a kutatásaimhoz kapcsolódó tanulmányok megírása során hasznos tanácsokkal látott el.

Hálával tartozom Dr. Pál Viktor tanár úrnak, aki ösztönzött részeredményeim tudományos konferenciákon történő bemutatására.

Köszönöm Szügyi Évának, hogy új témák és problémafelvetések felé irányította figyelmem, illetve köszönettel tartozom a közös publikációs tevékenységért, és konferencia részvételekért, amelyek értékes tapasztalatot jelentettek számomra.

Mindazonáltal köszönöm Dr. Papp Z. Attilának és Dr. Bodó Barnának hogy részese lehettem a 2014-ben végzett kutatásnak, amely az iskolaválasztás témája felé fordította a figyelmem.

Köszönöm továbbá azoknak a tanszéki munkatársaknak és kollégáknak a támogatást, akikkel az évek során alkalmam volt a témával kapcsolatos kérdéseket megvitatni, akik építő jellegü megjegyzéseikkel segítették munkám.

Hálával tartozom mindazoknak, akik a felmérés során kutatásomat segítették, itt köszönettel tartozom a nagykikindai, az újvidéki és a zombori pedagógusoknak, szülőknek és diákoknak, akik interjúalanyként részt vettek a kutatásban.

Végül, de nem utolsó sorban, köszönöm közeli barátaimnak, és családom tagjainak, különösképpen Férjemnek és Szüleimnek, hogy kutató munkám során mindvégig támogattak, és a terhek átvállalásával lehetővé tették számomra a szabad alkotómunkát. 
1. Interjúvázlat - pedagógus

\begin{tabular}{|c|c|c|}
\hline & & megjegyzés \\
\hline ÉLETTÖRTÉNET & $\begin{array}{l}\text { 1. Kérjük, röviden mesélje el, élettörténetét } \\
\text { a. mikor és hol született, } \\
\text { b. szülei milyen nemzetiségüek } \\
\text { c. szülei mivel foglalkoztak/nak } \\
\text { d. milyen nyelveken beszél? } \\
\text { e. valamilyen egyháznak tagja-e? } \\
\text { Vallásos-e? }\end{array}$ & $\begin{array}{l}\text { Elöször } \\
\text { hagyjuk } \\
\text { szabadon } \\
\text { beszélni, ha } \\
\text { ezekre a } \\
\text { témákra nem } \\
\text { tér ki, } \\
\text { kérdezzünk rá! }\end{array}$ \\
\hline CSALÁDI ÁLLAPOT & $\begin{array}{l}\text { 2. családi állapota } \\
\text { a. házastárs nemzetisége } \\
\text { b. házastárs iskolai életútja (milyen } \\
\text { típusú, illetve tannyelvű iskolákba } \\
\text { járt) }\end{array}$ & \\
\hline $\begin{array}{l}\text { SAJÁT ISKOLAI } \\
\text { ÉLETÚT }\end{array}$ & $\begin{array}{l}\text { 3. iskolai életútja: } \\
\text { a. hol és milyen típusú iskolákba járt } \\
\text { b. milyen nyelven végezte iskoláit } \\
\text { c. akár magyarul, akár szlovákul } \\
\text { végezte, kérdezzünk rá: } \\
\text { i. miért döntött ő vagy szülei } \\
\text { az ilyen nyelvü iskoláztatás } \\
\text { mellett? } \\
\text { ii. } \quad \text { szerinte ez jó vagy rossz } \\
\quad \text { döntés volt-e? } \\
\text { továbbképzéseken részt vett-e? Ha } \\
\text { igen, milyen képzések voltak ezek? } \\
\text { Saját iskolája támogatja-e, hogy } \\
\text { részt vegyen továbbképzéseken? }\end{array}$ & $\begin{array}{l}\text { Indokolja meg } \\
\text { a választ! }\end{array}$ \\
\hline $\begin{array}{l}\text { SAJÁT GYEREK } \\
\text { ISKOLÁZTATÁSA } \\
\text { Megj: csak ha van saját } \\
\text { gyereke! }\end{array}$ & $\begin{array}{l}\text { 4. gyerekek beiskolázása } \\
\text { a. } \text { milyen iskolába jár(nak) a } \\
\text { gyerek(ek)? } \\
\text { b. Kérjük, elevenítse fel, és mesélje el } \\
\text { nekünk, hogyan döntöttek a } \\
\text { gyerek(ek) iskoláztatásával } \\
\text { kapcsolatban } \\
\text { i. ki döntött? Ő? Házastárs? } \\
\text { Valaki más? } \\
\text { ii. } \\
\text { mikor döntöttek az } \\
\text { iskoláztatásról? (jóval az } \\
\text { első beiskolázás előtt? } \\
\text { közvetlenül az iskoláztatás } \\
\text { elött?) } \\
\text { iii. Kaptak-e valakitől erre } \\
\text { vonatkozó tanácsokat, } \\
\text { ajánlatokat? }\end{array}$ & $\begin{array}{l}\text { Ha nem tér ki } \\
\text { rá, rá kell } \\
\text { kérdezni! } \\
\text { Ha nem tér ki } \\
\text { rá, rá kell }\end{array}$ \\
\hline
\end{tabular}




\begin{tabular}{|c|c|c|}
\hline & 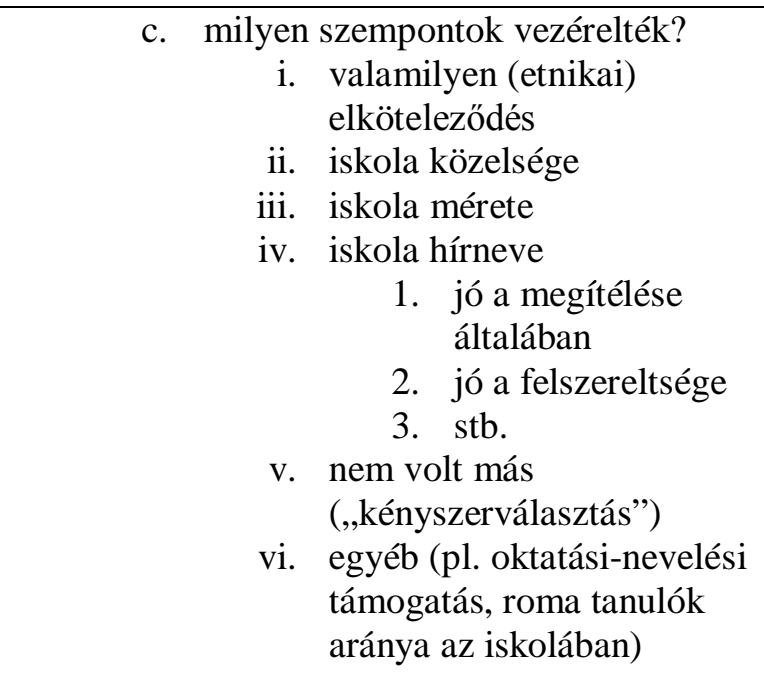 & kérdezni! \\
\hline $\begin{array}{l}\text { GYEREKEK HELYI } \\
\text { BEISKOLÁZTATÁSA }\end{array}$ & 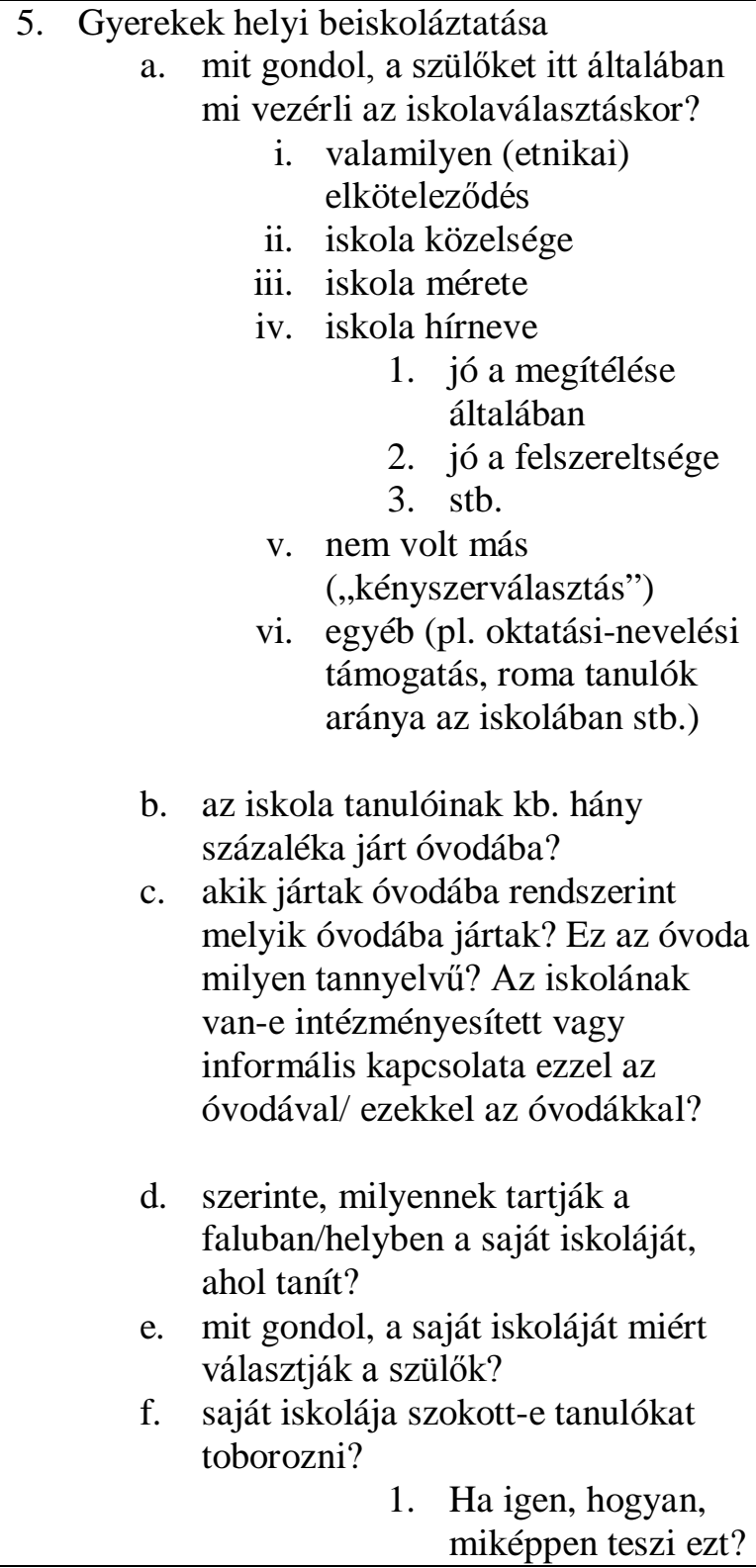 & $\begin{array}{l}\text { Ha nem tér ki } \\
\text { rá, rá kell } \\
\text { kérdezni! }\end{array}$ \\
\hline
\end{tabular}




\begin{tabular}{|c|c|}
\hline & 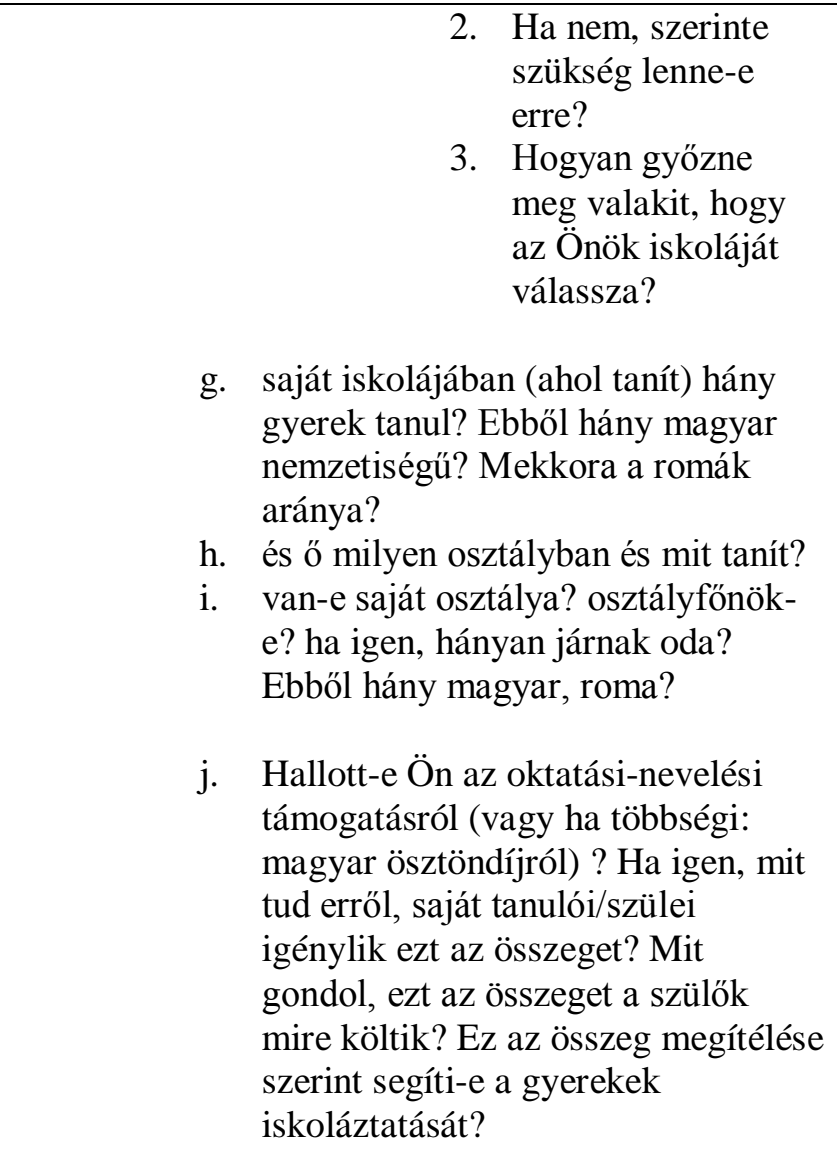 \\
\hline Nyelvi kérdések & $\begin{array}{l}\text { Jellemezze az iskolában folyó államnyelvoktatást } \\
\text { (módszerek, tanár attitúdje, képzettsége, tankönyvek, } \\
\text { hatékonyság szempontjából)! } \\
\text { Ön alkalmaz-e valamilyen módszert arra } \\
\text { vonatkozóan, hogy az államnyelv ne csak a } \\
\text { nyelvórákon, hanem más szaktantárgyak oktatásakor } \\
\text { (terminológia, osztott tannyelv) is megjelenjen? } \\
\text { Kollégái élnek-e ezzel a lehetőséggel? } \\
\text { Mi erről a véleménye? Szükség van-e erre } \\
\text { egyáltalán? } \\
\text { Jellemezze az iskolában folyó idegennyelv-oktatást } \\
\text { (módszerek, tanár attitüdje, képzettsége, tankönyvek, } \\
\text { hatékonyság szempontjából)! } \\
\text { Mit gondol, az itt tanulók gyerekek milyen szinten } \\
\text { tanulják meg az államnyelvet az iskolában? És az } \\
\text { idegen nyelveket? }\end{array}$ \\
\hline
\end{tabular}

Forrás: Az MTA Domus 2012.évi „Többségi nyelvű iskolaválasztás” című pályázatában használt interjúvázlat 


\begin{tabular}{|c|c|c|}
\hline & & megjegyzés \\
\hline ÉLETTÖRTÉNET & $\begin{array}{l}\text { 1. Kérjük, röviden mesélje el, élettörténetét } \\
\text { a. mikor és hol született, } \\
\text { b. szülei milyen nemzetiségüek } \\
\text { c. szülei mivel foglalkoztak/nak } \\
\text { d. milyen nyelveken beszél? } \\
\text { e. szüleivel milyen nyelven beszélt } \\
\text { f. vaerekkorában? } \\
\text { falamilyen egyháznak tagja-e? Vallásos-e? }\end{array}$ & $\begin{array}{l}\text { Elöször hagyjuk } \\
\text { szabadon beszélni, } \\
\text { ha ezekre a } \\
\text { témákra nem tér } \\
\text { ki, kérdezzünk rá! }\end{array}$ \\
\hline $\begin{array}{l}\text { CSALÁDI } \\
\text { ÁLLAPOT }\end{array}$ & $\begin{array}{l}\text { 2. családi állapota } \\
\text { a. házastárs nemzetisége } \\
\text { b. házastárs iskolai életútja (milyen típusú, } \\
\text { illetve tannyelvü iskolákba járt) }\end{array}$ & \\
\hline $\begin{array}{l}\text { SAJÁT ISKOLAI } \\
\text { ÉLETÚT }\end{array}$ & $\begin{array}{l}\text { 3. iskolai életútja: } \\
\text { a. hol és milyen típusú iskolákba járt } \\
\text { b. milyen nyelven végezte iskoláit } \\
\text { c. akár magyarul, akár szlovákul végezte, } \\
\text { kérdezzünk rá: } \\
\text { i. miért döntött ő vagy szülei az ilyen } \\
\quad \text { nyelvü iskoláztatás mellett? } \\
\text { ii. szerinte ez jó vagy rossz döntés volt- } \\
\text { e? }\end{array}$ & $\begin{array}{l}\text { Indokolja meg a } \\
\text { választ! }\end{array}$ \\
\hline $\begin{array}{l}\text { GYEREK } \\
\text { ISKOLÁZTATÁSA }\end{array}$ & $\begin{array}{l}\text { 4. gyerekek beiskolázása } \\
\text { a. járt-e óvodába gyereke? Ha igen, melyik } \\
\text { óvodába, illetve milyen nyelvü volt az? } \\
\text { Hogyan döntöttek az óvoda mellett? Ha több } \\
\text { gyereke van: ugyanabba az óvodába jártak-e? } \\
\text { b. milyen iskolába jár(nak) a gyerek(ek)? } \\
\text { c. Kérjük, elevenítse fel, és mesélje el nekünk, } \\
\text { hogyan döntöttek a gyerek(ek) } \\
\text { iskoláztatásával kapcsolatban } \\
\text { i. ki döntött? Ő? Házastárs? Valaki } \\
\text { más? } \\
\text { ii. mikor döntöttek az iskoláztatásról? } \\
\text { (jóval az első beiskolázás elött? } \\
\text { közvetlenül az iskoláztatás elött?) } \\
\text { iii. Kaptak-e valakitöl erre vonatkozó } \\
\text { tanácsokat, ajánlatokat? } \\
\text { milyen szempontok vezérelték? } \\
\text { i. valamilyen (etnikai) elköteleződés } \\
\text { ii. iskola közelsége } \\
\text { iii. iskola hírneve } \\
\text { 1. jó a megítélése általában } \\
\text { 2. jó a felszereltsége } \\
\text { 3. honnan szerzett információkat } \\
\text { az iskoláról vagy az ott } \\
\text { dolgozó pedagógusokról? } \\
\text { Hogyan döntötte el, hogy ez }\end{array}$ & $\begin{array}{l}\text { Ha nem tér ki rá, } \\
\text { rá kell kérdezni! } \\
\text { Ha több gyereke } \\
\text { van, mindegyikre } \\
\text { kérdezzünk rá! } \\
\text { Központi kérdés, } \\
\text { hogy ugyanabba } \\
\text { az intézménybe } \\
\text { jártak-e? }\end{array}$ \\
\hline
\end{tabular}




\begin{tabular}{|c|c|}
\hline & 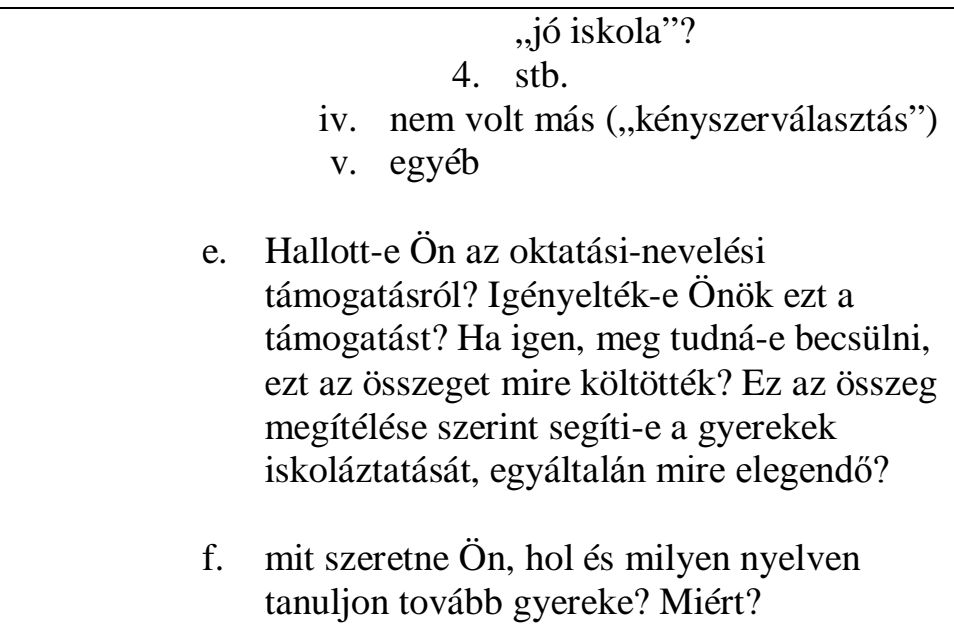 \\
\hline Nyelvi kérdések & $\begin{array}{l}\text { Elégedett az iskolában folyó államnyelvoktatással (a tanár } \\
\text { képzettsége, alkalmazott módszerek, tankönyvek, gyermeke } \\
\text { nyelvi fejlődése)? } \\
\text { Fontosnak tartja-e az államnyelv oktatását? } \\
\text { Elégedett az iskolában folyó idegennyelv-oktatással (a tanár } \\
\text { képzettsége, alkalmazott módszerek, tankönyvek, gyermeke } \\
\text { nyelvi fejlődése)? } \\
\text { Fontosnak tartja-e az idegen nyelvek oktatását? } \\
\text { Mit gondol, gyereke milyen szinten tanulta meg az } \\
\text { államnyelvet az iskolában? És az idegen nyelveket? } \\
\text { Milyen nyelven beszélnek otthon? } \\
\text { saját véleménye szerint, gyereke milyen szinten beszél } \\
\text { magyarul? }\end{array}$ \\
\hline
\end{tabular}

Forrás: Az MTA Domus 2012.évi „Többségi nyelvü iskolaválasztás” címü pályázatában használt interjúvázlat 


\section{Családi háttér}
a. mikor és hol születtél?
b. szüleid mivel foglalkoztak/nak?
c. szüleid milyen iskolákba jártak, esetleg tudod-e azt, milyen nyelven/nyelveken tanultak?
d. együtt élnek-e a szüleid?
e. ha röviden kellene megfogalmazni, mit gondolsz, a ti családotok inkább szegénynek, átlagosnak vagy gazdagnak minősül? Indokold meg a válaszod!
f. otthon milyen nyelven beszéltek?
g. vannak-e testvéreid? testvérek száma? milyen nyelven szoktatok testvéreiddel beszélgetni?
h. Esetleg tudod-e nagyszüleid mivel foglalkoznak/foglalkoztak?
i. (ha még élnek a nagyszülők) milyen nyelven szoktál nagyszüleiddel beszélgetni?

\section{Iskolai életút:}
a. jártál-e óvodába?
b. ha igen, hol és mennyi időt?
c. milyen nyelvü volt az az óvoda?

d. hol jártál iskolába? milyen nyelvü volt?

e. tudod-e hogy kerültél ebbe az iskolába, ahol most tanulsz?

f. ki döntött arról, hogy ide járj iskolába?

i. szerinted ez jó vagy rossz döntés volt-e?

HA VAN testvére: mesélje el, hogy ők is ugyanabba az óvodába/iskolába jártak-e? Ha nem szerinte miért történt ez így? Ök milyen nyelveken tanulnak?

g. hogyan birkózol meg a többségi nyelven tanulással? Ez jelent-e most valamilyen gondot?

h. Ha úgy érzed, ez már nem gond, fel tudod-e idézni, amikor elkezdted az iskolát, ez mit jelentett neked? Volt-e valamilyen nehézséged?

i. olvastál-e regényt az elmúlt fél évben? ha igen, mi volt a címe pontosan (ha nem derül ki, kérdezzük meg, milyen nyelven olvasta?)

j. a magyar és államnyelven kívül milyen nyelven beszélsz még?

k. milyen nyelvet tanítanak az iskolában? szerinted milyen szinten beszéled (esetleg: mondj egy mondatot angolul/franciául/stb...)

\section{Iskola jellemzése}

a. mekkora az iskola, hányan járnak ide? Szerinted az iskolába járnak-e magyarok? Ha igen, szerinted hány százaléka az iskola diákjainak magyar nemzetiségü?

b. van-e párhuzamos 7. osztály?

a. ha van, hogyan tudnátok jellemezni azokat, akik a másik osztályba járnak?

b. ha igen, van-e magyar nyelvü osztály is?

c. ha van, szeretnél-e másik osztályba járni? Indokold meg válaszod?

c. hányan jártok az osztályba? Ebből szerinted még hányan magyarok? És 


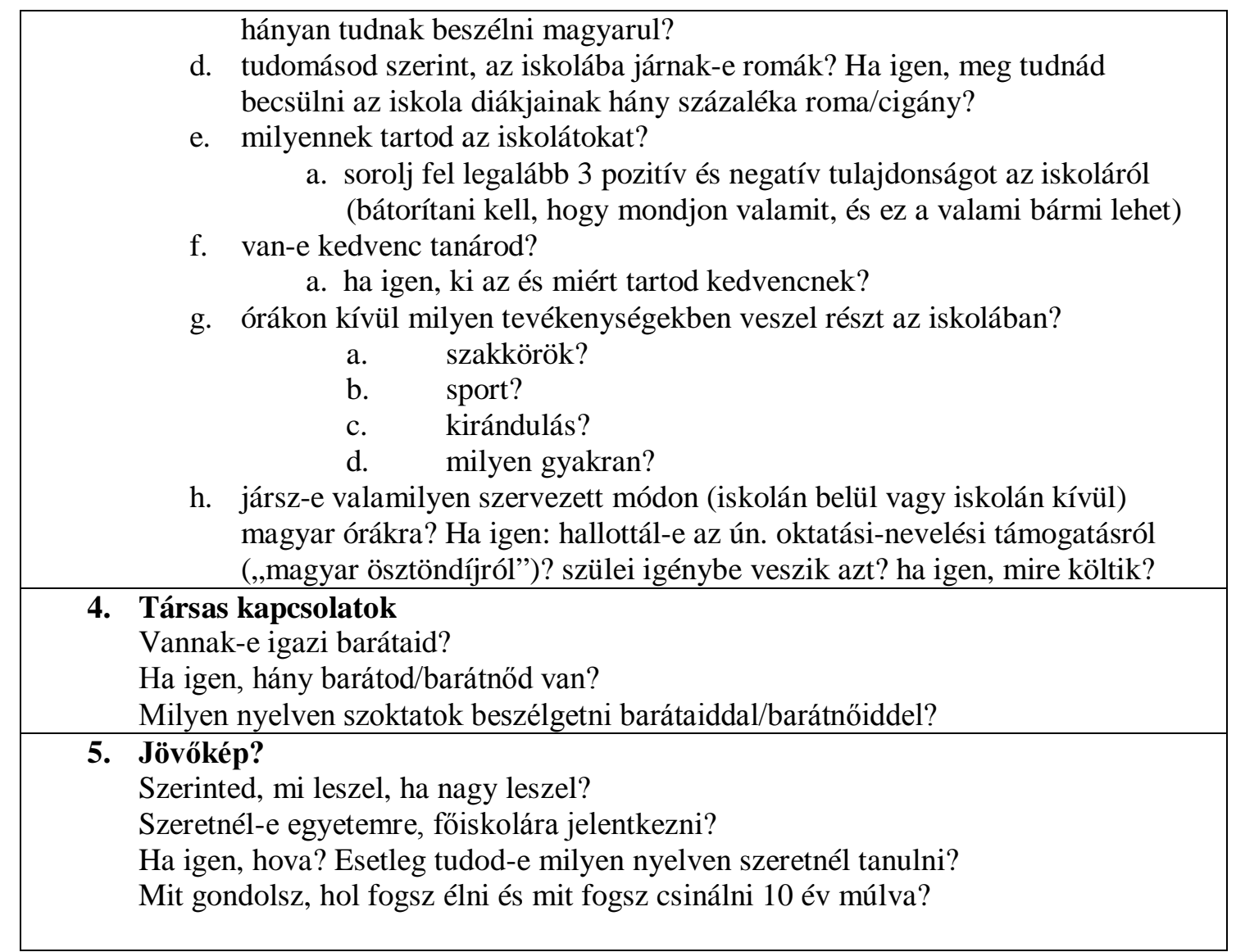

Forrás: Az MTA Domus 2012.évi „Többségi nyelvű iskolaválasztás” című pályázatában használt interjúvázlat 